\title{
A ESTRUTURA DA TORRE DE TV DIGITAL DE BRASÍLIA: ASPECTOS HISTÓRICOS E TECNOLÓGICOS DE PROJETO, INTERVENÇÕES E PROPOSTA DE MANUTENÇÃO
}

FELLIPE SOBREIRA SOARES

DISSERTAÇÃO DE MESTRADO EM ESTRUTURAS E CONSTRUÇÃO CIVIL

UNIVERSIDADE DE BRASÍLIA

FACULDADE DE TECNOLOGIA

DEPARTAMENTO DE ENGENHARIA CIVIL E AMBIENTAL 
UNIVERSIDADE DE BRASÍLIA

FACULDADE DE TECNOLOGIA

DEPARTAMENTO DE ENGENHARIA CIVIL E AMBIENTAL

\section{A ESTRUTURA DA TORRE DE TV DIGITAL DE BRASÍLIA: ASPECTOS HISTÓRICOS E TECNOLÓGICOS DE PROJETO, INTERVENÇÕES E PROPOSTA DE MANUTENÇÃO}

FELLIPE SOBREIRA SOARES

ORIENTADOR: GUILHERME SALES SOARES DE AZEVEDO MELO

CO-ORIENTADOR: CARLOS EDUARDO LUNA DE MELO

DISSERTAÇÃO DE MESTRADO EM ESTRUTURAS E CONSTRUÇÃO CIVIL

PUBLICAÇÃO: E.DM - 09A/17

BRASÍLIA - DF, 13 DE MARÇO DE 2017. 
UNIVERSIDADE DE BRASÍLIA

FACULDADE DE TECNOLOGIA

DEPARTAMENTO DE ENGENHARIA CIVIL E AMBIENTAL

A ESTRUTURA DA TORRE DE TV DIGITAL DE BRASÍLIA:

ASPECTOS HISTÓRICOS E TECNOLÓGICOS DE PROJETO,

INTERVENÇÕES E PROPOSTA DE MANUTENÇÃO

\section{FELLIPE SOBREIRA SOARES}

DISSERTAÇÃO DE MESTRADO SUBMETIDA AO DEPARTAMENTO DE ENGENHARIA CIVIL E AMBIENTAL DA FACULDADE DE TECNOLOGIA DA UNIVERSIDADE DE BRASÍLIA, COMO PARTE DOS REQUISITOS NECESSÁRIOS PARA OBTENÇÃO DO GRAU DE MESTRE EM ESTRUTURAS E CONSTRUÇÃO CIVIL.

APROVADA POR:

Prof. Guilherme Sales Soares de Azevedo Melo, PhD (UnB)

(Orientador)

Prof. Carlos Eduardo Luna de Melo, DSc (UnB)

(Co-Orientador)

Prof. Claudio Henrique de Almeida Feitosa Pereira, DSc (UnB) (Examinador Interno)

Prof. João Carlos Teatini de Souza Clímaco, PhD (UnB)

(Examinador externo)

BRASÍLIA - DF, 13 DE MARÇO DE 2017. 
FICHA CATALOGRÁFICA

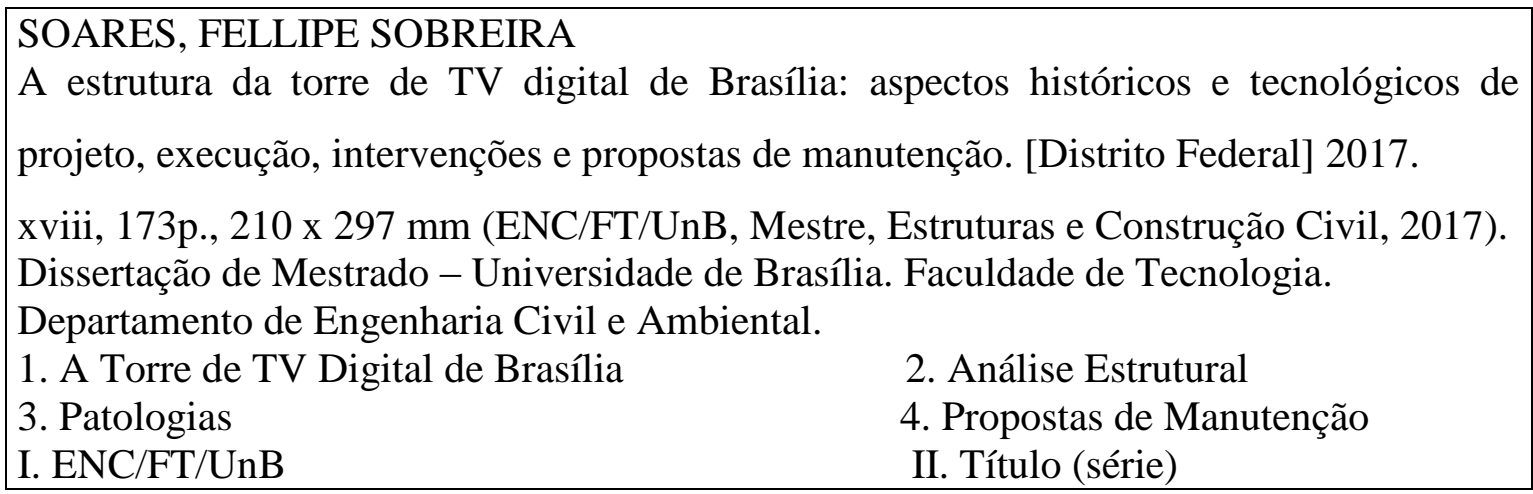

\section{REFERÊNCIA BIBLIOGRÁFICA}

SOARES, F. S. (2017). A Estrutura da Torre de TV Digital de Brasília: aspectos históricos e tecnológicos de projeto, execução, intervenções e propostas de manutenção. Dissertação de Mestrado em Estruturas e Construção Civil. Publicação E.DM - 09A/17, Departamento de Engenharia Civil e Ambiental, Universidade de Brasília, Brasília, DF, 173p.

\section{CESSÃO DE DIREITOS}

AUTOR: Fellipe Sobreira Soares

TÍTULO DA DISSERTAÇÃO DE MESTRADO: A Estrutura da Torre de TV Digital de Brasília: aspectos históricos e tecnológicos de projeto, execução, intervenções e propostas de manutenção.

GRAU: Mestre ANO: 2017

É concedida à Universidade de Brasília permissão para reproduzir cópias desta dissertação de mestrado e para emprestar ou vender tais cópias somente para propósitos acadêmicos e científicos. $\mathrm{O}$ autor reserva outros direitos de publicação e nenhuma parte dessa dissertação de mestrado pode ser reproduzida sem autorização por escrito do autor.

Fellipe Sobreira Soares

Avenida José Rodrigues, S/N - Centro, 64.550-000, São Francisco do Piauí-PI, Brasil. e-mail: fellipe.ss@ hotmail.com 


\section{AGRADECIMENTOS}

Agradecer em primeiro lugar a Deus, por sempre estar ao meu lado e por me proporcionar força, fé, paz e proteção.

Aos meus pais, Edna Maria e José Nazareno, pela confiança, pelo alicerce e pelo amor incondicional.

Aos meus irmãos, pelo incentivo, amor e admiração, e em especial minha irmã Camilla, por ter feito parte dessa caminhada.

Aos professores de Graduação, Ricardo Roque e Neuza Melo do Instituto Camilo Filho, (ICF) pelas cartas de recomendações, e aos doutores do Programa de Pós-graduação em Estruturas e Construção Civil (PECC/UnB) e do Programa de Pós-graduação em Arquitetura e Urbanismo da Universidade de Brasília (PPG-FAU/UnB) pelos os ensinamentos transmitidos, em especial os professores Guilherme Sales (orientador) e Carlos Luna (co-orientador), pela disponibilidade, apoio e incentivo durante o desenvolvimento dessa dissertação.

Agradecer também ao meu colega de aula o peruano Augusto Gonzales, que muito me ajudou nos ensinamentos com os programas computacionais.

A CAPES, pelo o suporte financeiro, disponibilizando bolsa de estudo para a elaboração dessa pesquisa.

A minha namorada Thayanne Monteiro, pelo apoio e carinho.

A toda minha família e amigos que acreditaram em minha capacidade e no meu potencial.

Que essa seja uma das muitas vitórias que virão.

Estou muito feliz. Amo todos vocês!

Muito Obrigado! 


\section{RESUMO}

\section{A ESTRUTURA DA TORRE DE TV DIGITAL DE BRASÍLIA: ASPECTOS HISTÓRICOS E TECNOLÓGICOS DE PROJETO, INTERVENÇÕES E PROPOSTA DE MANUTENÇÃO.}

\section{Autor: Fellipe Sobreira Soares \\ Orientador: Guilherme Sales Soares de Azevedo Melo \\ Co-orientador: Carlos Eduardo Luna de Melo \\ Programa de Pós-graduação em Estruturas e Construção Civil-PECC/UnB, Brasília, 13 de março de 2017.}

A Torre de TV Digital, apelidada de "Flor do Cerrado", com inauguração no dia 21 de abril de 2012, é o último projeto arquitetônico de Oscar Niemeyer executado em Brasília e calculada pelo o engenheiro José Carlos Sussekind. Possui 182 metros de altura, sendo 120 $\mathrm{m}$ de estrutura de concreto armado e $62 \mathrm{~m}$ de estrutura metálica, tendo ainda, duas cúpulas metálicas revestidas de vidro. Está localizada no planalto da região mais elevada da capital, no Alto Colorado, próximo a Sobradinho, fazendo parte do conjunto de monumentos do patrimônio cultural brasileiro. Pouco tempo depois de sua inauguração, apresentou vários problemas ligados à estética e à estrutura, principalmente, com o surgimento de infiltrações que deram origem à várias patologias, como manchas e fissurações, as quais acabaram ocasionando a interdição do monumento após uma vistoria feita em 2014 pelo Tribunal de Contas da União (TCU). Reaberta em 2015, nunca teve o seu funcionamento normalizado para o público. Nesse contexto, o objetivo principal desta pesquisa é avaliar as condições atuais da estrutura de concreto da Torre, a fim de investigar os aspectos de segurança, funcionalidade, durabilidade e estética, além de propor soluções para garantir o prolongamento de sua vida útil. Para a quantificação do grau de deterioração da estrutura da Torre foi utilizada a metodologia GDE/UnB desenvolvida no PECC, a partir de Castro (1994) e com última atualização feita por Fonseca (2007), além disso, foi realizada uma análise numérica computacional da estrutura utilizando o programa SAP2000, com o objetivo de avaliar seu desempenho. Com base nos resultados, verificou-se que a estrutura apresenta um grau de deterioração de nível médio na maioria dos elementos estruturais observados, sugerindo-se fazer intervenções em no máximo dois anos. Porém, para a laje de cobertura e para a laje do espelho d'água um grau de deterioração de nível alto, propondo-se a realização de intervenções em no máximo um ano. Com a avaliação da situação física atual da estrutura, conclui-se que o monumento necessita de alguns reparos (manutenções corretivas) e estratégias para programas de manutenções preventivas de longo prazo garantindo a extensão de sua vida útil, e assim ter seu funcionamento normalizado, a fim de continuar sendo um ponto turístico, um símbolo para Brasília.

Palavras-Chave: Torre de TV digital de Brasília; Análise Estrutural; Tecnologia de Projeto; Patologias e Recuperação dos Monumentos.

\section{ABSTRACT}




\title{
STRUCTURE OF DIGITAL TV BRASILIA TOWER: HISTORICAL ASPECTS AND PROJECT TECHNOLOGY, INTERVENTION AND MAINTENANCE OF PROPOSAL.
}

\author{
Author: Fellipe Sobreira Sores \\ Supervisor: Sales Guilherme Soares de Azevedo Melo \\ Co-supervisor: Carlos Eduardo Luna Melo \\ Pos-graduation Programme on Structures and Construction Civil - PECC / UNB \\ Brasília, 13 march 2017.
}

The digital TV Tower nicknamed "Flor do Cerrado", with the opening day April 21, 2012 is the last architectural project by Oscar Niemeyer executed in Brasilia and calculated by the engineer José Carlos Sussekind. The Tower is 182 meters tall, of which 120 meters of reinforced concrete structure, more 62 meters of steel structure and has two glass domes. Is located in the plateau of the higher capital region, in Alto Colorado near Sobradinho, making part of the Brazilian cultural heritage monuments. The work soon after your inauguration presented several problems linked to the aesthetics and structure, especially with the emergence of infiltrations which gave rise to various pathologies, such as stains and craks, which ended up leading to the ban of the monument after a survey made in 2014 by the Tribunal de Contas da União (TCU), reopened in 2015 never had the standard operation for your audience. In this context, the main objective of this research is to assess the current conditions of the concrete structure of the Tower, in order to investigate the security aspects, functionality, durability and aesthetics, as well as propose solutions to ensure the extension of the useful life of the monument. From an inspection program following a GDE / UnB methodology developed in the PECC, from Castro (1994) and last update by Fonseca (2007) to quantify damages in concrete structures, and with the help of the SAP 2000 for software Modeling and structural analysis, reached a medium degree of deterioration in most structural elements observed, suggesting plan interventions in a maximum of two years. As cover slabs and slab of water mirror because of cracks caused by thermal variations, they ended up indicating a high level of deterioration, alerting for a maximum intervention period in one year. With the evaluation of current physical position of the structure, it is concluded that the work requires some repairs (corrective maintenance) and strategies for a program of preventive maintenance to ensure the extension of the useful life of the work, and so have your standard operation and continue being a great tourist spot, a symbol for Brasilia and source of pride for Brazilians.

Keywords: Digital TV tower of Brasília; Structural analysis; Project Technology; Pathologies and Restoration of Monuments. 


\section{SUMÁRIO}

1 INTRODUÇÃO 1

1.1 MOTIVAÇÃO 3

1.2 OBJETIVOS 4

1.2.1 Objetivo Geral 4

1.2.2 Objetivos Específicos 4

1.3 METODOLOGIA 5

1.4 ESTRUTURA DO TRABALHO 6

2 REFERENCIAL TEÓRICO 9

2.1 A HISTÓRIA DE BRASÍLIA 9

2.1.1 O surgimento de Brasília 9

2.1.2 Obras de Oscar Niemeyer realizadas em Brasília 11

2.1.3 O Tombamento 16

2.2 PESQUISAS REALIZADAS SOBRE OS MONUMENTOS DE BRASÍLIA 17

$\begin{array}{lll}2.2 .1 & \text { Pessoa (2002) } & 17\end{array}$

2.2.2 Santos Jr (2004) 21

2.2.3 Moreira (2007) 25

2.2.4 Souza (2009) 32

2.2.5 Bessa et al. (2013) 35

2.2.6 Conclusões a cerca das pesquisas realizadas 38

2.3 PRINCÍPIOS GERAIS DA AVALIAÇÃO DE ESTRUTURAS DE CONCRETO 39

2.3.1 Aspectos gerais 39

$\begin{array}{lll}\text { 2.3.2 Investigação } & 40\end{array}$

2.3.3 Desempenho Estrutural 44

$\begin{array}{lll}2.3 .4 & \text { Diagnóstico } & 48\end{array}$

2.3.5 Avaliação da segurança 48

2.4 METODOLOGIA GDE/UnB PARA QUANTIFICAÇÃO DO GRAU DE DETERIORAÇÃO DA ESTRUTURA 49

2.4.1 Divisão em famílias de elementos 51

2.4.2 Fator de ponderação do dano (Fp) 51

2.4.3 Fator de intensidade do dano (Fi) 52

2.4.4 O Grau do dano (D) e Grau de deterioração de um elemento (Gde) 52 
2.4.5 Grau de deterioração de uma família de elementos (Gdf)

2.4.6 Grau de deterioração da estrutura $(\mathrm{Gd})$ e o Fator de relevância estrutural (Fr) 53

2.5 CONSIDERAÇÕES GERAIS SOBRE MANUTENÇÃO DE ESTRUTURAS 54

2.5.1 Conceitos importantes 54

2.5.2 Durabilidade, vida útil, desempenho e patologias 54

2.5.3 Manutenção das estruturas

3 TORRE DE TV DIGITAL DE BRASÍLIA

3.1 PROJETO ARQUITETÔNICO 61

3.2 ESTUDO DA AÇÃO DO VENTO NA ESTRUTURA

3.3 ESTRUTURA DA FUNDAÇÃO 64

3.4 PLANEJAMENTO EXECUTIVO 64

3.5 EXECUÇÃO

$\begin{array}{lll}3.5 .1 & \text { Execução das estacas } & 67\end{array}$

$\begin{array}{lll}3.5 .2 & \text { Execução do fuste } & 69\end{array}$

$\begin{array}{lll}3.5 .3 & \text { Execução da ferragens } & 71\end{array}$

$\begin{array}{lll}3.5 .4 & \text { Execução do cálice } & 71\end{array}$

$\begin{array}{lll}3.5 .5 & \text { Execução dos Braços } & 72\end{array}$

$\begin{array}{lll}3.5 .6 & \text { Execução das calotas esféricas } & 73\end{array}$

$\begin{array}{lll}3.5 .7 & \text { Execução das cúpulas geodésicas } & 73\end{array}$

$\begin{array}{lll}3.5 .8 & \text { Execução da rampa de acesso a Torre } & 74\end{array}$

$\begin{array}{lll}3.5 .9 & \text { Execução da torre metálica } & 75\end{array}$

3.6 SUSTENTABILIDADE E AUTOSSUFICIÊNCIA 76

$\begin{array}{lll}3.6 .1 & \text { Reuso da água da chuva } & 76\end{array}$

$\begin{array}{lll}3.6 .2 & \text { Sistema de esgoto } & 76\end{array}$

$\begin{array}{lll}3.7 & \text { INTERVENÇÕES } & 77\end{array}$

4 AVALIAÇÃO DA ESTRUTURA DA TORRE DE TV DIGITAL DE

BRASÍLIA $\quad 79$

$\begin{array}{lll}4.1 & \text { INTRODUÇÃO } & 79\end{array}$

4.2 CARACTERÍSTICAS DA INSPEÇÃO

4.3 CLASSIFICAÇÃO DA AGRESSIVIDADE DO AMBIENTE 80

4.4 METODOLOGIA GDE/UnB PARA QUANTIFICAÇÃO DO GRAU DE DETERIORAÇÃO DA ESTRUTURA DA TORRE DE TV DIGITAL 82

4.4.1 Divisão em famílias de elementos $\quad 82$ 
4.4.2 Fator de ponderação do dano (Fp) 82

4.4.3 Fator de intensidade do dano (Fi) 83

4.4.4 O Grau (D) de cada dano e Grau de deterioração de um elemento (Gde) 84

4.4.5 Grau de deterioração de uma família de elementos (Gdf) 88

4.4.6 Grau de deterioração da estrutura $(\mathrm{Gd})$ e o Fator de relevância estrutural (Fr) $\quad 89$

4.5 DISCUSSÃO DOS RESULTADOS 91

5 MODELAGEM ESTRUTURAL 95

$\begin{array}{lll}5.1 & \text { INTRODUÇÃO }\end{array}$

5.2 PROCEDIMENTO ADOTADO 95

5.2.1 Modelagem no SAP 2000 e discretização da estrutura 95

$\begin{array}{lll}\text { 5.2.2 Carregamentos } & 98\end{array}$

5.2.3 Combinações de Ações: ELU e ELS 100

5.3 PARÂMETROS ADOTADOS PARA A ESTRUTURA DE CONCRETO: NORMA ABNT NBR 6118:2014 101

5.4 RESULTADOS DA MODELAGEM 102

5.4.1 Verificações Estado Limite de Serviço: ELS 102

5.4.2 Verificações Estado Limite último: ELU 104

5.4.3 Consideração do efeito de segunda ordem em barras esbeltas 105

5.5 COMPARAÇÃO DOS RESULTADOS DA MODELAGEM COM OS DADOS DE BESSA ET AL. (2013) 111

6 PROPOSTAS DE MANUTENÇÃO PARA A TORRE DE TV DIGITAL DE BRASÍLIA

$\begin{array}{lll}6.1 & \text { INTRODUÇÃO } & 112\end{array}$

6.2 MANUTENÇÃO CORRETIVA 113

6.3 MANUTENÇÃO PREVENTIVA 115

7 CONCLUSÕES 117

7.1 CONSIDERAÇÕES GERAIS 117

7.2 HISTÓRIA, PROJETOS E INTERVENÇÕES 117

7.3 QUANTIFICAÇÃO DA DETERIORAÇÃO DA ESTRTUTURA DA TORRE PELA METODOLOGIA GDE/UnB

7.4 ANÁLISE NUMÉRICA DA ESTRUTURA PELO MÉTODO DOS ELEMENTOS FINITOS 
7.5 PROGRAMA DE MANUTENÇÃO PARA A ESTRUTURA DA TORRE DE TV DIGITAL DE BRASÍLIA 122

7.6 SUGESTÕES PARA TRABALHOS FUTUROS 123

REFERÊNCIAS BIBLIOGRÁFICAS 


\section{LISTA DE TABELAS}

Tabela 1- Reações de apoio nos modelos dos programas SAP 2000 e ANSYS -

Tabela 2 - Valores máximos e deslocamentos nos modelos 2D e 3D - Pessoa (2002) ....... 20

Tabela 3 - Grau de deterioração da estrutura (Gd) e prazo para intervenção - Pessoa (2002)

Tabela 4 - Comparação das armaduras calculadas pela ABNT NBR 6118:2003, com o projeto original (bitolas em polegadas) - Santos Jr (2004).

Tabela 5 - Comparação cargas de fundação SAP2000 e projeto original - Santos Jr (2004)

Tabela 6 - Comparação das flechas no SAP2000 e a ABNT NBR 6118:2003 -

Santos Jr (2004)

Tabela 7 - Grau de deterioração de cada elemento (Gde), das famílias de elementos (Gdf) e da estrutura principal do prédio (Gd) - Santos Jr (2004)

Tabela 8 - Grau de deterioração de cada elemento (Gde), das famílias de elementos (Gdf) e das estruturas das passarelas e do lago circundante - Santos Jr (2004).

Tabela 9 - O grau de deterioração global da estrutura do Palácio da Justiça (Gd) - Moreira (2007)

Tabela 10 - O grau de deterioração global da estrutura do Palácio de Justiça (Gd) após as intervenções - Moreira (2007)

Tabela 11 - Grau de deterioração global da estrutura do grupo A (internos secos) e das famílias do grupo C (ambientes externos) - Souza (2009)

Tabela 12 - Classificação dos níveis de deterioração do elemento (Gde) - Fonseca (2007)

Tabela 13 - Classificação dos níveis de deterioração da estrutura (Gd) - Fonseca (2007). 54

Tabela 14 - Indicação de intervalos de inspeção (em anos) - FIP (1988)

Tabela 15 - Classificação da agressividade dos ambientes da Torre de TV Digital de Brasília.

Tabela 16 - Qualidade do projeto e cobrimento: Norma ABNT NBR 6118:2014 x

Especificações do Projeto

Tabela 17 - Famílias de alguns elementos da torre, danos e fatores de ponderação 82

Tabela 18 - Grau do dano (D), dos elementos estruturais vistoriados da Torre de TV Digital 
Tabela 19 - Grau de deterioração do elemento (Gde) dos elementos estruturais vistoriados da Torre de TV Digital de Brasília

Tabela 20 - Planilhas e detalhes das inspeções de algumas famílias de elementos estruturais da Torre de TV Digital de Brasília .86

Tabela 21 - Grau de deterioração das famílias de elementos (Gdf) da estrutura da Torre de

TV Digital de Brasília 88

Tabela 22 - Determinação do grau de deterioração da estrutura (Gd) da Torre de TV

Digital de Brasília. 89

Tabela 23 - Classificação dos níveis de deterioração da estrutura - Fonseca (2007) ......... 90

Tabela 24 - Modelagem Sap2000: Estrutura de Aço............................................................ 96

Tabela 25 - Modelagem Sap2000: Estrutura de Concreto.................................................. 97

Tabela 26 - Carregamento adotada na estrutura da Torre de TV Digital de Brasília ........... 98

Tabela 27 - Combinações de ações: Estado Limite Ultimo (ELU) .................................. 100

Tabela 28 - Combinações de ações: Estado Limite de Serviço (ELS) .............................. 101

Tabela 29 - Parâmetros adotados para a estrutura de concreto da Torre de TV Digital.... 102

Tabela 30 - Verificação dos deslocamentos horizontais máximo (ação do vento) e verticais:

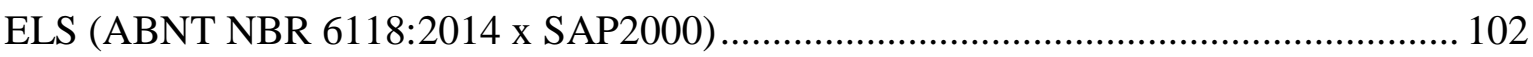

Tabela 31 - Verificação da rotação máxima: ELS 02 (ABNT NBR 6118:2014 x SAP2000)

Tabela 32 - Tensões atuante na estrtura da Torre de TV Digital de Brasília ..................... 104

Tabela 33 - Esforços máximos na base do fuste de 50 cm (SAP2000): ELU 01 ............... 105

Tabela 34 - Esforços Nd e Md2 majorados na base do fuste de $50 \mathrm{~cm}$.............................. 108

Tabela 35 - Verificação do dimensionamento do fuste de $50 \mathrm{~cm}$ : ELU 01....................... 109

Tabela 36 - Prazos para intervenção dos elementos estruturais da Torre de TV Digital de Brasília..... 


\section{LISTA DE FIGURAS}

Figura 1 - Projeto urbanístico de Lúcio Costa do plano piloto de Brasília - (ArPDF)........ 11

Figura 2 - Vista aérea da esplanada dos ministérios ( Google Earth) - Moreira (2007) ..... 12

Figura 3 - Congresso Nacional de Brasília -.................................................................... 13

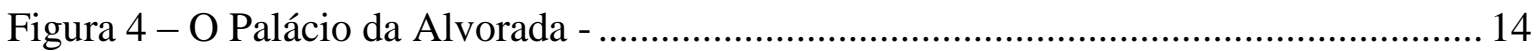

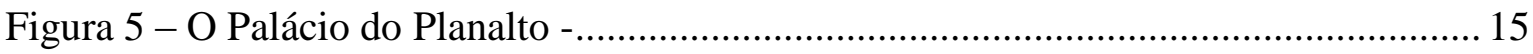

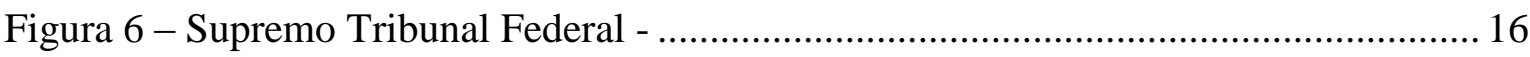

Figura 7 - Conjunto da Catedral de Brasília - Pessoa (2002) ........................................... 18

Figura 8 - Deslocamentos, na direção Z (metros), da estrutura da Catedral de Brasília,

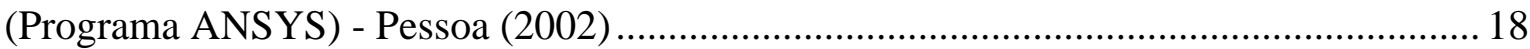

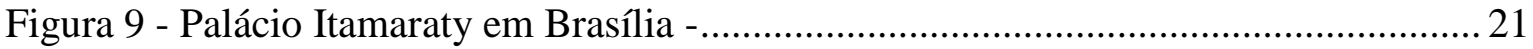

Figura 10 - Modelação volumétrica na plataforma CAD - Santos Jr (2004) ...................... 22

Figura 11 - Diagrama de forças cortante no pórtico A, direção leste-oeste, SAP2000 -

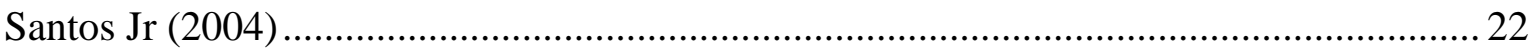

Figura 12 - Diagrama de forças cortante no pórtico B, direção norte-sul, .......................... 23

Figura 13 - Palácio da Justiça em Brasília - .......................................................................... 26

Figura 14 - Perspectiva: estrutura da fachada sul, com as cascatas, e fachada leste, CAD/TQS - Moreira (2007)

Figura 15 - Deslocamento das estruturas do $4^{\circ}$ e $5^{\circ}$ pavimentos, em $\mathrm{cm}, \mathrm{CAD} / \mathrm{TQS}$ -

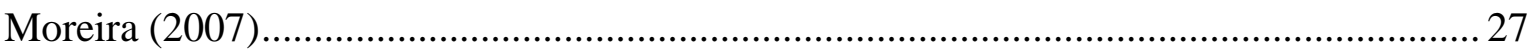

Figura 16 - deslocamentos na cobertura, em cm. CAD/TQS - Moreira (2007) .................. 28

Figura 17 - Deslocamentos horizontais devido ações do vento de incidência de $0^{\circ}$ -

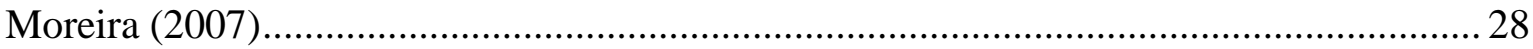

Figura 18 - Deslocamentos horizontais devidos ação do vento de incidência de $90^{\circ}$ Moreira (2007)

Figura 19 - Grau de deterioração das famílias de elementos do Palácio da Justiça Moreira (2007)

Figura 20 - O grau de deterioração das famílias de elemento do edifício (Gdf) após as intervenções - Moreira (2007)

Figura 21 - Maquete Eletrônica do Teatro Nacional Claudio Santoro (ITS/Brasília) Souza (2009).

Figura 22 - Vista geral do modelo da estrutura principal do Teatro Nacional no SAP2000 Souza (2009) 
Figura 23 - grau de deterioração das famílias da estrutura principal do Teatro Cláudio Santoro - Souza (2009)

Figura 24 - Tipologia da estrutura analisada no SAP2000 - Bessa et al. (2013)

Figura 25 - Parâmetros e esquema das estacas, modelo no SAP2000 - Bessa et al. (2013) 36

Figura 26 - Etapas de inspeções das estruturas de concreto - ABECE (2005).

Figura 27 - Fluxograma para avaliação do grau de deterioração de estruturas de concreto da metodologia GDE/UnB - Fonseca (2007) .... .50

Figura 28 - Conceitos relacionados com patologias das construções 55

Figura 29 - Fases de desempenho de uma estrutura durante sua vida útil - adaptada do CEB (1992) e Helene (1992) .56

Figura 30 - Lei de evolução de custos - adaptado de SITTER (1984). 56

Figura 31 - Modelo de desempenho de uma estrutura sob manutenção periódica - Moreira (2007) apud Cunha (2006) 58

Figura 32 - Localização via satélite da Torre de TV Digital de Brasília, coordenadas geográficas: $15^{\circ} 41^{\prime} 31^{\prime} \mathrm{S}$ e $47^{\circ} 51^{\prime} 13^{\prime} \mathrm{W}$ -

Figura 33 - Planta de situação da estrutura da Torre de TV Digital de Brasília (NOVACAP)

Figura 34 - Fachada principal da estrutura da Torre de TV Digital de Brasília (NOVACAP) 62

Figura 35 - Protótipo para a realização do ensaio no túnel de vento - Gorgulho (2012) .... 63

Figura 36 - Etapas dos planejamentos executivos dos processos construtivos da Torre de TV Digital de Brasília - adaptado Gorgulho (2012) 67

Figura 37 - Execução das estacas - Gorgulho (2012) ........................................................ 68

Figura 38 - Erguimento da armadura do fuste da base em concreto e aço - (ArPDF) ........ 70

Figura 39 - Detalhe da construção do cálice da Torre de TV Digital de Brasília - (ArPDF)

Figura 40 - Execução dos braços externos da Torre de TV Digital de Brasília - (ArPDF). 72

Figura 41 - Execução dos braços de apoio das cúpulas - (ArPDF) ..................................... 72

Figura 42 - Calotas esféricas, com cúpulas metálica geodésica -...................................... 73

Figura 43 - Execução das rampas de acesso a Torre -....................................................... 74

Figura 44 - Fixação da torre metálica, detalhe 1 - retirado do projeto executivo................ 75

Figura 45 - Torre de TV Digital de Brasília finalizada - .................................................... 75 
Figuras 46 - Fator de intensidade (Fi) de alguns elementos estruturais da Torre de TV Digital de Brasília.

Figura 47 - Gráfico representativo do grau de deterioração das famílias (Gdf) de elementos

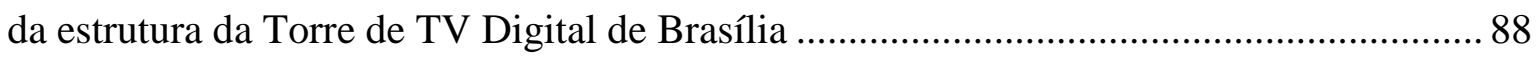

Figura 48 - Modelo tridimensional a ser analisado - (SAP2000) ....................................... 98

Figura 49 - Forças horizontais devido à ação do vento $90^{\circ}$ e $0^{\circ}$ - (SAP2000) .................... 99 Figura 50 - Divisão do fuste (pilar parede) em setores para obtenção dos esforços máximo

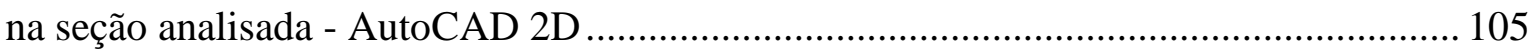

Figura 51 - Divisão do pilar-parede em faixas verticais - ABNT NBR 6118:2014 .......... 106 Figura 52 - Esforços para o dimensionamento da faixa do bordo mais solicitado - ABNT

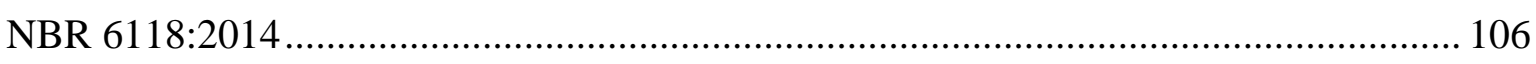

Figura 53 - Pilar bi-rotulado - ABNT NBR 6118:2014_.................................................. 107 Figura 54 - Distribuição da armadura do fuste da Torre (projeto original), da elevação $6,0 \mathrm{~m}$ a $+42,30 \mathrm{~m}$, adaptado projeto Cad 2D - NOVACAP 110 Figura 55 - Proposta de modelo para o desempenho da Torre de TV Digital de Brasília apud Moreira (2007) 


\section{LISTA DE ABREVIAÇÕES}

ABNT - Associação Brasileira de Normas Técnicas;

ABECE - Associação Brasileira de Engenharia e Consultoria Estrutural;

ArPDF - Arquivo Público do Distrito Federal;

ANATEL - Agência Nacional de Telecomunicações;

ABECE - Associação Brasileira de Engenharia e Consultoria Estrutural;

ANSYS -Simulation Driven Product Development (Analysis System);

CAA - Classe de Agressividade Ambiental;

CAD - Computer Aided Design;

CEB - Comitê Euro International du Beton;

D - Dano do Elemento;

ETALP - Escritório Técnico Arthur Luiz Pitta;

ELU - Estado Limite Ultimo;

ELS - Estado Limite de Serviço;

FIP - Federação Internacional da Protensão para Estruturas de Concreto Armado e Protendido;

Fp - Fator de Ponderação do Dano;

Fi - Fator de Intensidade de Dano;

Fr - Fator de Relevância Estrutural;

GDE - Grau de Deterioração das Estruturas de Concreto;

Gde - Grau de Deterioração do Elemento;

Gdf - Grau de Deterioração Família de Elementos;

Gd- Grau de Deterioração da Estrutura;

$\mathrm{Hz}$ - Frequência;

$\mathrm{H}$ - Altura;

ICOMOS - Conselho Internacional de Monumentos e Sítios; 
IBAMA - Instituto Brasileiro do Meio Ambiente e dos Recursos Naturais Renováveis; ICOMOS - Conselho Internacional de Monumentos e Sítios;

IPT - Instituto de Pesquisas Tecnológicas;

IPHAN - Instituto do Patrimônio Histórico e Artístico Nacional;

JK - Juscelino Kubitscheck;

LSE - Laboratório de Sistemas Estruturais;

$\mathrm{L}$ - Vão;

MEF - Métodos dos Elementos Finitos;

NBR - Normas Técnicas Brasileiras;

NOVACAP - Companhia Urbanizadora da Nova Capital;

NASTRAN - Análise estrutural da NASA;

NBR - Normas Brasileiras;

PECC - Programa de Pós-Graduação em Estruturas e Construção Civil

P - Pressão;

SAP - Structural Analysis Program;

STF - Supremo Tribunal Federal;

SI - Sistema Internacional;

TCU - Tribunal de Contas da União;

TQS - Tecnologia e Qualidade em Sistemas;

TERRACAP - Companhia Imobiliária de Brasília;

$\mathrm{T}$ - Temperatura;

UnB - Universidade de Brasília;

UNESCO - Organização das nações Unidas para a educação, a Ciência e a Cultura. 


\section{LISTA DE SÍMBOLOS}

ai - Largura pilar parede;

D- Rigidez à flexão do elemento;

E - Módulo de elasticidade do material;

e2 - Excentricidade de segunda ordem;

Eci - Módulo de elasticidade inicial;

Fd - Combinações de ações;

Fck - Resistência a compressão do concreto;

fct,m - Resistência a tração do concreto;

Fyk - Resistência de escoamento do aço;

Ecs - Módulo de elasticidade secante;

Gc - Módulo de elasticidade transversal;

le - Comprimento de flambagem;

Md - Esforço Momento fletor de cálculo;

Nd - Esforço Normal de cálculo;

Pei - Carga de flambagem do pilar;

Rd - Esforço resistente de cálculo;

Sd - Esforço solicitante de cálculo;

үf - Majoração das cargas atuantes;

ym - Coeficiente de redução da resistência dos materiais;

бc - Tensão de compressão do concreto;

$\mathrm{t}$ - Espessura da parede;

$v$ - Coeficiente Poisson do material;

$\beta$ - Fator de amplificação de momentos;

$\delta \mathrm{t}$ - Deslocamento no topo da torre de concreto;

Ө - Ângulo. 


\section{INTRODUÇÃO}

A inauguração de Brasília no dia 21 de abril de 1960 marca a transferência e a interiorização da capital para a região geográfica central do Brasil, realizando um sonho do então presidente da república Juscelino Kubitscheck (JK), que com fé e força de vontade conseguiu construir nos seus cinco anos de mandato essa belíssima cidade.

A Capital tornou-se funcional e atraente com sua estética espetacular expressando a novidade, a audácia e a plasticidade nela inserida através de suas formas simples e curvas puras, sendo essas características vistas nos monumentos históricos do arquiteto genial Oscar Niemeyer, no urbanismo moderno de Lúcio Costa, na qual prevalece os seus eixos que se cruzam, as vias largas, as suas superquadras e as grandes áreas verdes expostas no paisagismo de Roberto Burle Marx.

Com todas essas qualidades, a criação de Brasília representou um marco na história do urbanismo e da arquitetura, recebendo em 1987 o título de Patrimônio Cultural da Humanidade - única cidade do mundo construída no século XX com essa denominaçãoreconhecida pela Organização das Nações Unidas para a Educação, a Ciência e a Cultura (UNESCO), que em parceria com o Instituto do Patrimônio Histórico e Artístico Nacional (IPHAN) puderam realizar o tombamento desse sítio e de alguns monumentos históricos, sendo esses órgãos os responsáveis por acompanhar a preservação e a evolução da capital. E ao Arquivo Público do Distrito Federal (ArPDF) foi encarregado salvaguardar e armazenar todos os documentos que contam a história do surgimento de Brasília, as plantas dos projetos de urbanismo e das obras dos monumentos históricos.

Os monumentos que fazem parte desse sítio tombado pela UNESCO, que se destacam pela inovação e arrojo estrutural, demandam programas de manutenção efetiva que preservem as suas características originais e garantam a sua vida útil. No entanto, dificilmente essas edificações passam por reparos ou intervenções, e quando ocorrem, já existe um grau avançado de deterioração, o que torna ainda mais complicado e mais oneroso esses serviços.

Apesar da engenharia brasileira, ter se preocupado em estudar e registrar esses monumentos de grande destaque no cenário estrutural e arquitetônico, a partir do desenvolvimento de vários trabalhos na linha de pesquisa: "Patologia, Manutenção, Análise e Recuperação das Estruturas", o levantamento de dados pra se ter o conhecimento dessas edificações é difícil de ser realizado, pois já não é possível encontrar todos os 
projetos originais ou cópias, e acaba deixando para trás a história, as técnicas construtivas, a estrutura, a estética e a funcionalidade que elas proporcionam.

Muitos desses trabalhos foram desenvolvidos no Programa de Pós-graduação em Estruturas e Construção Civil-PECC (UnB), a maioria sob orientação dos professores João Carlos Teatini e Antônio Alberto Nepomuceno, com os seguintes monumentos e autores: A Catedral: Pessoa (2002); Palácio Itamaraty: Santos Jr (2004); Palácio da Justiça: Moreira (2007); ICC-UnB: Fonseca (2007); Monumento a Caxias e do Teatro Calmon: Silva (2008); Teatro Nacional: Souza (2009) e outros desenvolvidos pela FAU/UnB, além de artigos científicos, como a Torre de TV Digital: Bessa et al. (2013) e de outras Instituições de Ensino Superior - IES, como a UFF.

Logo, em Brasília, esses monumentos tombados pela UNESCO acabam se deteriorando por falta de manutenção e por outros aspectos de descaso com o patrimônio público, porém, esses danos ocorrem até mesmo com obras recém-inauguradas as quais são danificadas com pouco tempo de uso. A Torre de TV Digital, objeto de estudo desta pesquisa, é um exemplo desse descaso com as obras públicas no Brasil, pois mesmo depois da sua inauguração, nunca teve seu funcionamento por completo.

Segundo Gorgulho (2012), a Torre apelidada de "Flor do Cerrado" é o mais recente monumento de Brasília projetado pelo arquiteto Oscar Niemeyer e calculada pelo engenheiro José Carlos Sussekind. Está situada no planalto da região mais elevada de Brasília, no Alto Colorado, próximo a Sobradinho, em um terreno de $40.000 \mathrm{~m}^{2}$, que fica aproximadamente a $20 \mathrm{~km}$ do centro de Brasília.

A construção da Torre teve início em 15 de junho de 2009 e a inauguração em 21 de abril de 2012, juntamente com o aniversário de 52 anos de Brasília. Porém, pouco tempo depois de sua inauguração apresentou vários problemas ligados à estética e à estrutura, principalmente, com o surgimento de infiltrações que deram origem a várias patologias, como manchas e fissurações, as quais acabaram ocasionando a interdição do monumento após uma vistoria feita em 2014 pelo Tribunal de Contas da União (TCU). Porém reaberta em 2015, nunca teve seu funcionamento ao público normalizado, de acordo com informações extraídas da rádio Revista Brasília, publicada no ano de 2015, onde em entrevista com o engenheiro Márcio Buzar, diretor de edificações da Companhia Urbanizadora da Nova Capital do Brasil (NOVACAP), são apresentados todos os problemas na estrutura do monumento, baseado no laudo feito pelo corpo técnico do Tribunal de Contas de União do Distrito Federal. 
Portanto, no intuito de avaliar as condições físicas da Torre e de verificar se essas patologias influenciam ou não no seu desempenho estrutural é que nasce essa pesquisa.

Essa verificação do desempenho será feita a partir de inspeções (vistoria na obra) e simulação do comportamento estrutural da Torre, ou seja, uma previsão de como a estrutura responde às combinações de ações atuantes. É feito uma modelagem tridimensional e uma análise numérica linear da estrutura a partir do programa computacional SAP2000, um software de modelagem em elementos finitos, caracterizado pela discretização ou decomposição da estrutura em malha, dividindo o modelo em um número finito de partes ou elementos conectados entre si, por nós.

O trabalho visa ainda, aumentar as informações sobre esses monumentos históricos e de poucos estudos científicos falando de obras atuais como a Torre de TV Digital, marcante pela sua audácia estrutural e estética. Com o intuito de continuar construindo uma trajetória para a engenharia civil do país, através da avalição da situação atual da Torre e adotar propostas de estratégias de manutenção corretiva e preventiva para garantir sua vida útil e longa.

\subsection{MOTIVAÇÃO}

A Torre de TV Digital foi o último projeto arquitetônico de Oscar Niemeyer executado em Brasília, e existem poucos trabalhos científicos publicados sobre o projeto na literatura, apenas um artigo científico, Bessa et al. (2013) e o livro "Flor do Cerrado", Gorgulho (2012). Baseado nisso, é possível identificar a necessidade de um trabalho que caracterize a concepção, o cálculo e a execução dessa obra que é um marco para Brasília e um ponto turístico para a capital.

O monumento pouco tempo depois de sua inauguração apresentou vários problemas ligados à estética e à estrutura, principalmente com o surgimento de infiltrações que deram origem a várias patologias, como manchas e fissurações, as quais acabaram ocasionando a interdição da edificação em 2014 pelo Tribunal de Contas da União. Reaberta em 2015 nunca teve seu funcionamento normalizado. Neste contexto, cabe verificar se essas patologias possuem ou não relação com o desempenho estrutural.

A partir de uma comparação dos resultados numéricos obtidos no programa computacional, baseado nas normas vigentes, e de realizações de inspeções para a avaliação das condições físicas atuais da Torre, pode-se encontrar uma relação entre as patologias e o desempenho estrutural. 
Diante do exposto, é motivação da pesquisa estudar, conhecer e analisar a estrutura desse monumento emblemático de grande importância para a engenharia estrutural brasileira, pela sua audácia, novidade, arrojo, a plástica e a estética. O intuito é destacar o projeto, o cálculo, as técnicas construtivas, sua forma, a construção, seus defeitos e seu desempenho, além de medir o grau de deterioração da estrutura e propor estratégias de manutenção.

Este trabalho dá continuidade a uma sequência de trabalhos desenvolvidos no PECC-UnB na linha de pesquisa: "Patologia, Manutenção, Análise e Recuperação das Estruturas”, com os seguintes monumentos e autores: A Catedral: Pessoa (2002); Palácio Itamaraty: Santos Jr (2004); Palácio da Justiça: Moreira (2007); ICC-UnB: Fonseca (2007); Monumento a Caxias e do Teatro Calmon: Silva (2008), Teatro Nacional: Souza (2009) e outros.

\subsection{OBJETIVOS}

\subsubsection{Objetivo Geral}

O objetivo geral do presente trabalho é estudar, analisar e avaliar as condições da estrutura da Torre de TV Digital de Brasília em relação à segurança, estética, funcionalidade e durabilidade, com intuito de adotar propostas de manutenção para garantir a extensão da vida útil do monumento.

\subsubsection{Objetivos Específicos}

Os objetivos específicos são apresentados a seguir:

- Descrever a história, o projeto, a estrutura, o planejamento executivo, as intervenções realizadas na obra, apresentar as etapas de construção, os materiais utilizados, a tecnologia construtiva e a execução da obra, a fim de conhecer o monumento a ser avaliado e para elencar os parâmetros a serem utilizados na modelagem estrutural;

- Analisar o comportamento da estrutura pelo Método dos Elementos Finitos (MEF), utilizando o programa computacional SAP 2000 e comparar os resultados obtidos com as prescrições das normas ABNT NBR 6123:1988 e ABNT NBR 6118:2014, para verificar se atende os requisitos das normas vigentes, e se há alguma relação entre as patologias e o seu desempenho estrutural;

- Realizar inspeção na obra para levantar possíveis manifestações patológicas, danos e suas causas, e posteriormente avaliar o grau de deterioração da estrutura; 
- Quantificar o grau de deterioração da estrutura com a aplicação da metodologia GDE/UnB desenvolvida no PECC, a partir de Castro (1994) e modificada por Lopes (1998), Boldo (2002) e Fonseca (2007), com intuito de definir prazos e ações a serem adotadas;

- Propor estratégias para um programa de manutenção preventiva de longo prazo, a fim de garantir a vida útil do monumento arquitetônico.

\subsection{METODOLOGIA}

A metodologia a ser empregada para atingir os objetivos é descrita a seguir:

1. Referencial teórico: a maioria das informações sobre o surgimento de Brasília, os monumentos históricos de Oscar Niemeyer e a estrutura da Torre de TV Digital foram encontrados em algumas dissertações de mestrado que seguem essa linha de pesquisa; no Arquivo Público do Distrito Federal (ArPDF) e a partir de autores que tratam do assunto, livros, artigos, internet, rádio, revistas e jornais, a fim de estudar a história, o projeto, a construção, a execução e as técnicas construtivas.

Também foram elencados alguns princípios para a avaliação das estruturas de concreto, uma espécie de guia prático utilizado na inspeção, feito a partir do documento lançado pelo Conselho Internacional de Monumentos e Sítios ICOMOS (2001), no Comitê Internacional para a Análise e Restauro de Estruturas do Patrimônio Arquitetônico, no qual se estabelece metodologias de análise racionais e métodos de intervenção apropriados ao contexto cultural, com o intuito de preservar e garantir uma vida longa para os monumentos históricos.

2. Metodologia GDE/UnB: para a avaliação das condições físicas atuais da Torre Digital de Brasília, faz-se necessária uma inspeção da estrutura, para levantar as possíveis patologias e as causas delas, e definir o grau de deterioração da estrutura de concreto por meio da utilização da metodologia GDE/UnB desenvolvida no PECC, a partir de Castro (1994) e modificada por Lopes (1998), Boldo (2002) e Fonseca (2007). Houve várias dissertações que utilizaram a metodologia, como Euqueres (2011) que avaliou pontes de concreto armado e Verly (2015) que avaliou obras de artes especiais - OAEs juntamente com o DNIT, em rodoviárias localizadas na região metropolitana de Brasília. 
3. Modelagem Estrutural: para a avaliação do comportamento estrutural da Torre foi utilizado o programa computacional SAP2000, onde é feita uma modelagem tridimensional a partir dos projetos arquitetônicos e estruturais que foram cedidos pela NOVACAP e uma análise numérica elástico-linear para a verificação dos esforços no elemento da estrutura, avaliando o desempenho estrutural (ELS Estado Limite de Serviço) e verificando a segurança do edifício (ELU - Estado Limite Último).

4. Programa de manutenção: em posse da quantificação do grau de deterioração pela metodologia GDE/UnB e dos resultados obtidos na modelagem estrutural no programa SAP2000, são adotadas propostas de uma estratégia de manutenção para o monumento, a partir de vários autores e referências que tratam de reparos e manutenção, visando assegurar a vida útil longa da Torre, sobretudo, garantir a segurança, estética, funcionalidade e durabilidade do patrimônio.

\subsection{ESTRUTURA DO TRABALHO}

Para melhor compreensão desta pesquisa, o estudo foi dividido em 7 Capítulos, além de referências, apêndices e anexos. O Capítulo 1 apresenta a parte introdutória, composta pela apresentação do estudo, a motivação, os objetivos e a metodologia utilizada para o desenvolvimento deste trabalho.

O Capítulo 2 apresenta uma descrição sucinta do surgimento de Brasília e o seu tombamento, as principais obras de Oscar Niemeyer e alguns estudos já realizados sobre esses monumentos históricos no Distrito Federal. Relata também os critérios gerais para avaliação das estruturas de concreto, usando o documento desenvolvido pelo ICOMOS (2001) como parâmetros para a realização da investigação, inspeção da estrutura e do desempenho estrutural, além de outros autores que trazem informações sobre manutenções das estruturas.

No Capítulo 3 apresenta um levantamento de dados sobre a estrutura da Torre de TV Digital de Brasília, relatando a sua história, a concepção, o projeto arquitetônico, o projeto estrutural, o planejamento executivo, a execução e suas intervenções.

O Capítulo 4 mostra a avaliação das condições da estrutura da Torre de TV Digital de Brasília no seu estado atual, onde é feito a quantificação do grau de deterioração das 
estruturas de concreto armado pela metodologia GDE/UnB desenvolvida no PECC, a partir de Castro (1994) e com última atualização feita por Fonseca (2007).

O Capítulo 5 tem o objetivo de avaliar e analisar a concepção estrutural da Torre, por meio da utilização do programa computacional SAP2000, onde é feita uma modelagem tridimensional e uma análise numérica elástico-linear para a verificação dos esforços no elemento da estrutura, avaliando o desempenho estrutural (ELS) e verificando a segurança do monumento (ELU).

Em posse da quantificação do grau de deterioração da estrutura e dos resultados obtidos na modelagem estrutural descrito nos capítulos anteriores, o Capítulo 6 propõe uma estratégia de manutenção para a Torre de TV Digital de Brasília, visando assegurar sua vida útil e longa, e sobretudo, garantir a segurança, a estética, a funcionalidade e a durabilidade do patrimônio público.

O Capítulo 7 destina-se as conclusões e sugestões para trabalhos futuros, além de referências, apêndices e anexos.

Apêndice A - Planilhas com os resultados da avalição da inspeção na Torre de TV Digital de Brasília, onde é quantificado o grau de deterioração nos elementos estruturais inspecionados segundo a metodologia GDE/UnB desenvolvida no PECC, a partir de Castro (1994) e com última atualização feita por Fonseca (2007).

Apêndice B - Demonstração do cálculo das combinações de ações para a Torre de TV Digital de Brasília, conforme prescrições da norma ABNT NBR 6118:2014.

Apêndice C - Forças devido a ação do vento atuante na Torre de TV Digital, nas direções de incidência de $0^{\circ}$ e $90^{\circ}$, conforme prescrições da norma ABNT NBR 6123:1988.

Anexo A - Conceitua os tipos de danos mais frequentes em estruturas de concreto. O texto faz parte do roteiro de inspeção da metodologia GDE/UnB desenvolvida no PECC, a partir de Castro (1994) e com última atualização feita por Fonseca (2007).

Anexo B - Planilhas para a realização de inspeção rotineira em estruturas de concreto. $\mathrm{O}$ anexo faz parte da proposta do programa de manutenção. Sendo composta por três tabelas:

-A Tabela B.1 - classificação dos danos, fatores de intensidade (Fi) e tipos de manifestaçãoes, parte da metodologia GDE/UnB desenvolvida no PECC, a partir de Castro (1994) e com última atualização feita por Fonseca (2007); 
-A Tabela B.2 - famílias de elementos estruturais a serem investigados, com os principais danos e respectivos fatores de ponderação $(\mathrm{Fp})$;

-A Tabela B.3 - apresenta as tipologias de fissuras em elemento de concreto armado. 


\section{REFERENCIAL TEÓRICO}

\subsection{A HISTÓRIA DE BRASÍLIA}

A ideia de interiorização da capital do país surgiu há 255 anos, desde o período colonial, já em 1761 quando o então $1^{\circ}$ ministro de Portugal Marquês de Pombal propunha mudar a capital do império português para o interior do Brasil colônia.

Segundo Vasconcelos (1989) “A escolha de 21 de abril para a mudança da capital foi uma feliz ideia, pois coincide com a data comemorativa de Tiradentes, o Mártir da Independência, que é, também, o primeiro brasileiro a desejar e a propor a transferência da capital, do litoral para o interior, ainda em 1789".

Essa ideia de centralização da capital mais tarde foi defendida pelos Inconfidentes e depois inserida na Constituição Federal, isso mostra que a construção de Brasília é resultado de muitas lutas e desafios. Esses desafios são citados no livro "Flor do Cerrado" de Gorgulho (2012):

Desafios constitucionais: em 1823, José Bonifácio de Andrade e Silva propôs à assembléia constituinte que a capital do império fosse para o planalto central. A constituição de 1934 previu a construção da nova capital, já em 1937, a mesma pressupôs a transferência da sede do governo.

Desafios políticos: Floriano Peixoto constitui a Missão Cruls com a função de demarcar o quadrilátero da nova capital $\left(14.440 \mathrm{~km}^{2}\right)$ e principalmente a determinação do governo de Juscelino Kubitscheck com a construção de Brasília entre 1956 e 1960, e inauguração em 21 de abril de 1960.

Desafios econômicos: o país teve que dispor de renda para investir na nova capital e consequentemente ganha desenvolvimento econômico, social e cultural com a integração do centro oeste, do norte e do nordeste.

Desafios culturais: na nova capital se concentrava todas as tradições, todos rituais, todas as diversidades e todas as crenças, representando a variedade da nação brasileira.

\subsubsection{O surgimento de Brasília}

No dia 31 de janeiro de 1956, Juscelino Kubitscheck assume a presidência da república do Brasil para um mandato de cinco anos, com a meta de construir a nova capital do país no planalto central, no intuito de ser a nova sede do governo e contribuir para o 
desenvolvimento da região Centro-Oeste, do Norte e do Nordeste, além da integração com as demais regiões do país.

O livro de Gorgulho (2012) informa que já no dia 19 de setembro de 1956 é aprovada a lei $\mathrm{N}^{\circ} 2.874$ pelo presidente $\mathrm{JK}$, que delimita oficialmente o território do Distrito Federal $\left(5.783 \mathrm{Km}^{2}\right.$ ), cria a Companhia Urbanizadora da Nova Capital (NOVACAP) e define o nome de Brasília para a nova capital do Brasil.

A NOVACAP, órgão responsável pela construção da cidade, presidida por Israel Pinheiro que elabora o "Edital do Concurso Nacional do Plano Piloto da Nova Capital do Brasil", publicando no Diário Oficial da União em 30 de setembro de 1956. Já em 16 de março de 1957 a comissão julgadora do concurso nacional para a escolha do projeto urbanístico para a nova capital define o arquiteto urbanista Lúcio Costa como vencedor.

O urbanista Lúcio Costa menciona que seu projeto (Figura 1), nasceu do gesto primário de quem assinala um lugar ou dele toma posse: dois eixos cruzando-se em ângulo reto, ou seja, o próprio sinal-da-cruz.

De forma geral, o plano piloto foi dividido em quatro escalas: monumental ou eixo LesteOeste (atividades federais e locais: obras públicas do arquiteto Oscar Niemeyer); residencial ou eixo Norte-Sul (residências e serviços: casas, clubes, bibliotecas, igrejas, escolas, etc.); gregária (onde se situam os setores bancário, hoteleiro, comercial e de diversões) e bucólica (formada pelas áreas livres e arborizadas, conferindo a Brasília o caráter de cidade-parque), cortado por dois eixos que se cruzam. As ruas e esquinas foram substituídas por pistas ou eixos, eliminando os cruzamentos e separando a circulação de pedestres dos veículos. Todos os detalhes do projeto, como plantas e memoriais, estão sobre cuidados do Arquivo Público do Distrito Federal (ArPDF).

A construção de Brasília, só foi possível devido o empenho do presidente JK, com sua vontade política; Lúcio Costa, por ter feito o primeiro risco de um plano urbano livre e disciplinado; Oscar Niemeyer, por ter desenhado curvas sensuais para sustentar a leveza e a beleza nos seus monumentos históricos; Israel Pinheiro, primeiro presidente da NOVACAP, que empurrou o sonho da construção da capital para a realidade e os engenheiros envolvidos, como Joaquim Cardozo, que através dos seus cálculos conseguiu erguer essas verdadeiras obras de arte, sem o uso de computador, feitas apenas na ponta do lápis. 


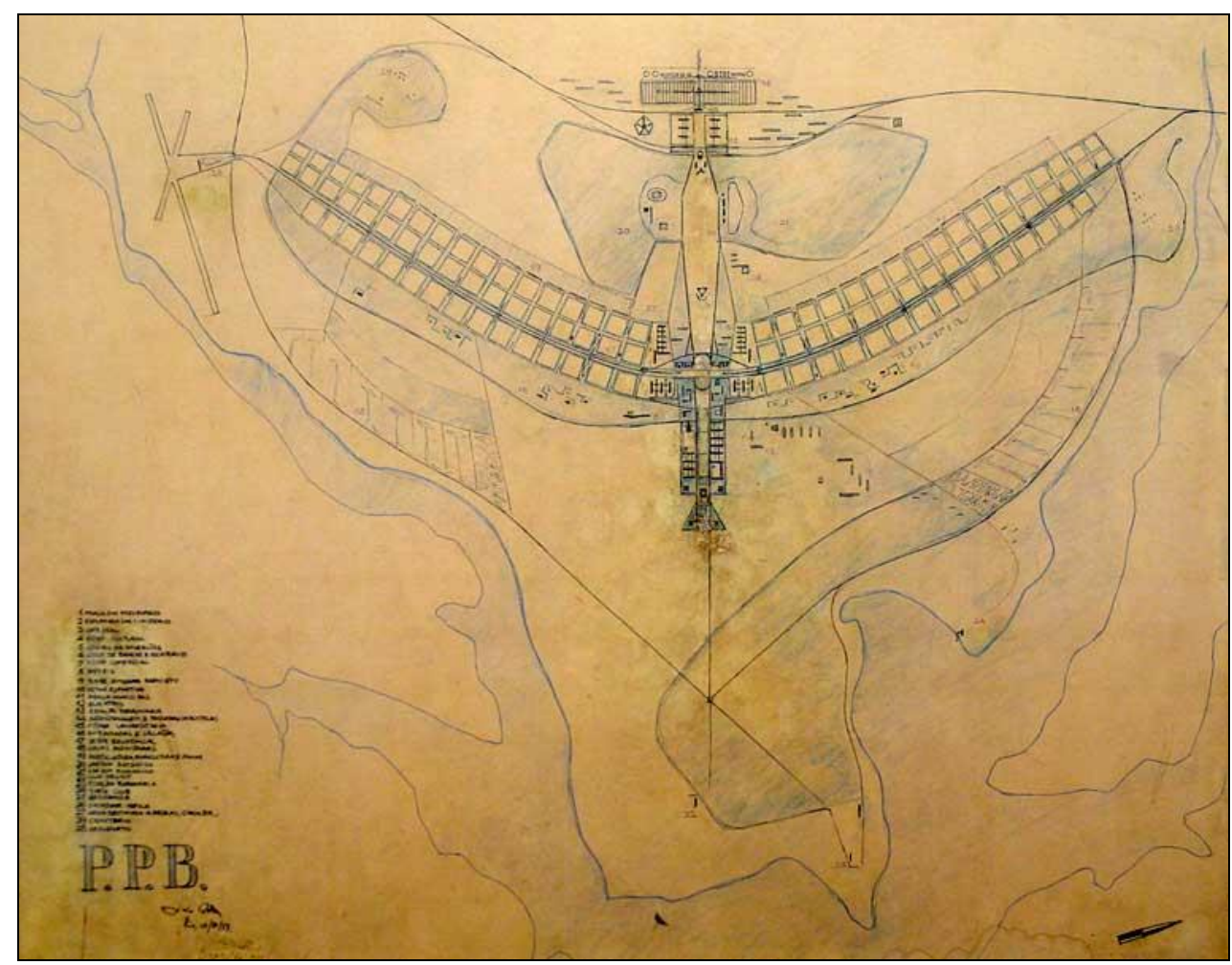

Figura 1 - Projeto urbanístico de Lúcio Costa do plano piloto de Brasília - (ArPDF)

\subsubsection{Obras de Oscar Niemeyer realizadas em Brasília}

O arquiteto Oscar Niemeyer, já conhecido do então presidente da república Juscelino Kubitscheck desde os tempos que era governador em Minas Gerais, onde juntos criaram o complexo de lazer para a cidade, "Pampulha" sendo consagrado pelo arrojo de formas, a plasticidade escultural, formas criativas e inovadoras, adaptando o concreto armado as suas curvas simples e puras.

Gorgulho (2012) aborda que em 1957, como Líder do departamento de Arquitetura, Oscar Niemeyer elabora os projetos arquitetônicos dos principais monumentos de Brasília, sendo os mais representativos dessa época, destacando pelo apuro tecnológico como mostra a Figura 2: a Catedral, o Congresso Nacional, o Palácio da Alvorada, o Palácio do Planalto, o Palácio da Justiça, o Palácio Itamaraty, o Supremo Tribunal Federal, os Ministérios e outros, dos quais a maioria foram calculados pelo engenheiro Joaquim Cardozo.

Em Brasília, Oscar Niemeyer em seus projetos demonstrou a harmonia entre a arquitetura e a engenharia, como coisas que nascem juntas, e articuladas se enriquecem, utilizando o sistema estrutural como definição da forma - através dos materiais como o concreto armado, o protendido e estruturas metálicas - conseguiu dar essa forma plástica e funcionalidade para os edifícios. 
Pela importância da engenharia estrutural, a audácia, a novidade, o arrojo, e técnicas de projeto e construção, vale apena ressaltar as características de algumas dessas principais obras desse arquiteto genial. Uma abordagem destacando a estrutura, as técnicas construtivas e os avanços tecnológicos dos principais monumentos de Brasília.

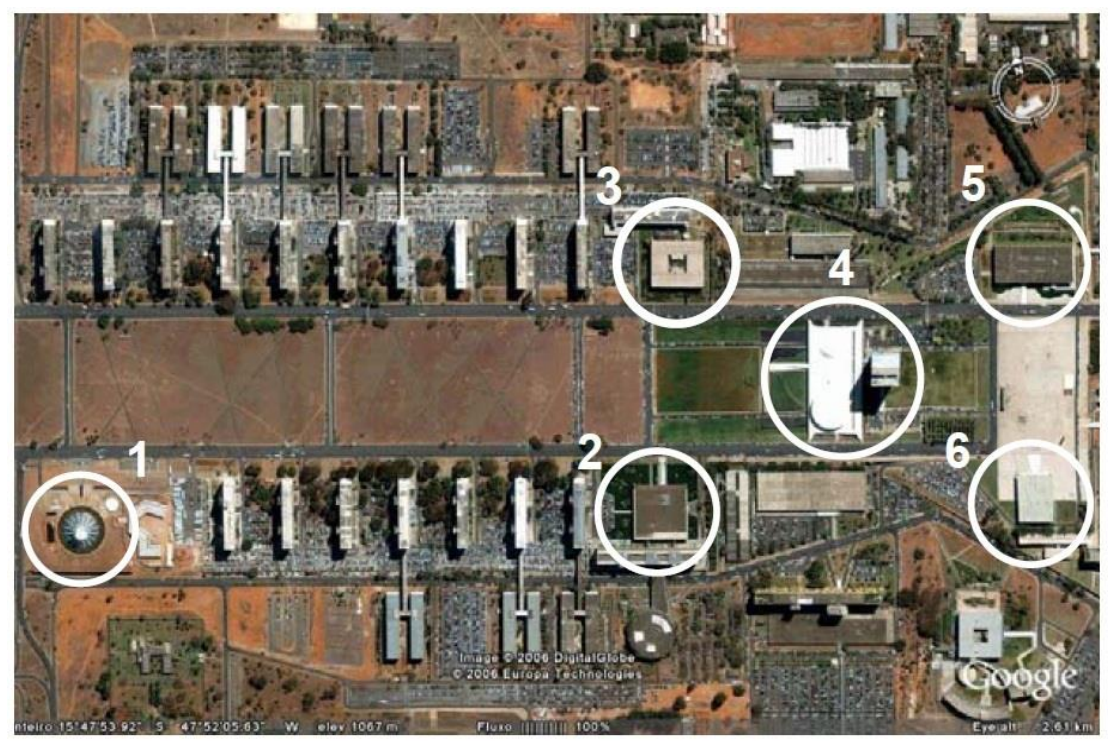

Legenda:

1- Catedral Metropolitana

2- Palácio do Itamaraty

3- Palácio da Justiça

4- Congresso Nacional

5- Palácio do Planalto

6- Palácio do Supremo

Tribunal Federal

Figura 2 - Vista aérea da esplanada dos ministérios ( Google Earth) - Moreira (2007)

\subsubsection{O Congresso Nacional}

O Congresso Nacional, construído entre 1957 e 1960, está situado no extremo leste do Eixo Monumental e compõe a Praça dos Três Poderes, juntamente com o Palácio do Planalto e o Supremo Tribunal Federal, representando o Poder Legislativo, Poder Executivo e Poder Judiciário.

Projeto arquitetônico de Oscar Niemeyer, e plano estrutural de Joaquim Cardozo, o Congresso consiste em um edifício principal, na horizontal, que serve de plataforma, uma espécie de base para as cúpulas do Senado Federal e da Câmara dos Deputados.

A cúpula menor, voltada para baixo, abriga o Plenário do Senado Federal e a cúpula maior, voltada para cima, abriga o Plenário da Câmara dos Deputados. Atrás do edifício principal e entre as duas cúpulas se encontram duas torres de 28 pavimentos em estrutura metálica e laje de concreto: uma delas pertence à Câmara e a outra ao Senado, como mostra a Figura 3. 


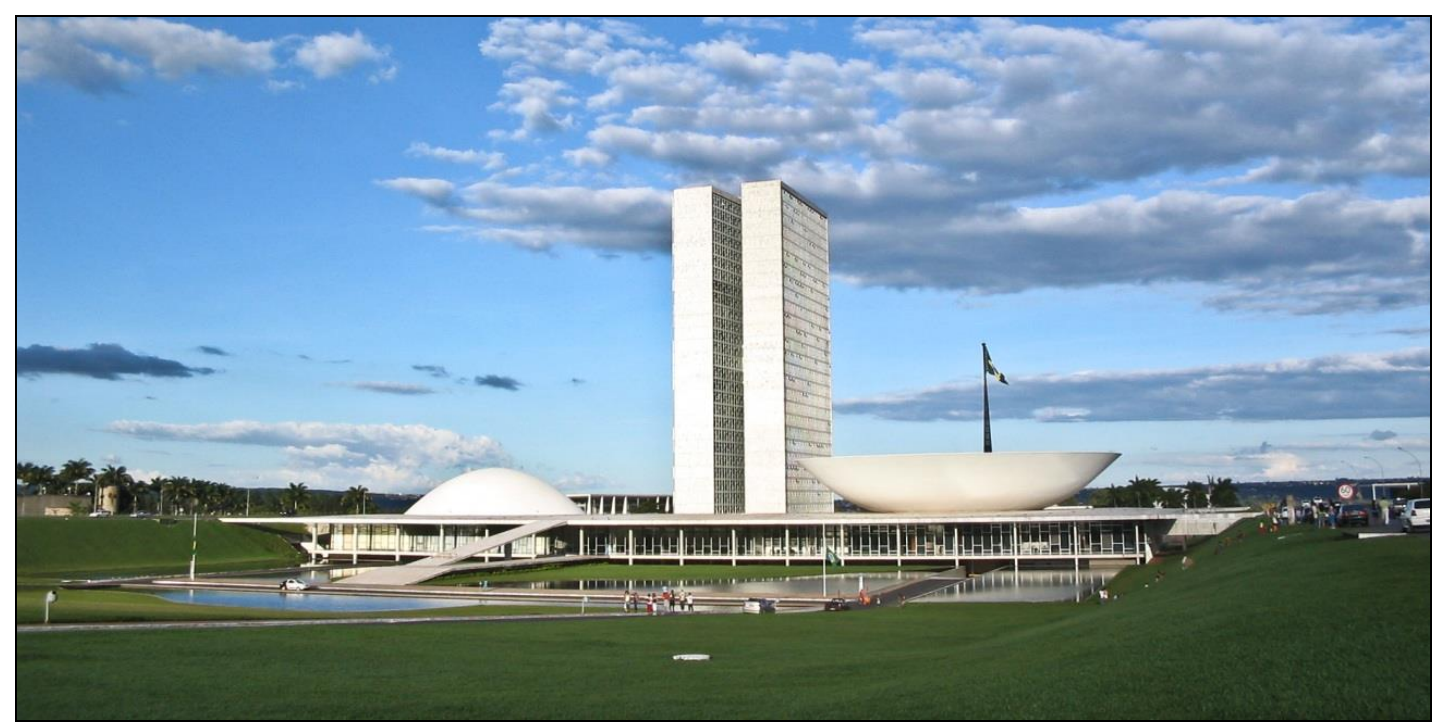

Figura 3 - Congresso Nacional de Brasília -

Disponível em: < www.turismoinformativo.com.br/wp-content/uploads/2016/01/congresso-1-of-1.jpg>. Acesso em: 14/01/2017

Em 2007, no centenário de Oscar Niemeyer, o Instituto do Patrimônio Histórico e Artístico Nacional (IPHAN) decidiu pelo tombamento do edifício do Congresso Nacional.

Segundo Oscar Niemeyer:

No Palácio do Congresso, por exemplo, a composição se formulou em função desse critério, das conveniências da arquitetura e do urbanismo, dos volumes, dos espaços livres, da oportunidade visual e das perspectivas e, especialmente, da intenção de lhe dar o caráter de monumentalidade, com a simplificação de seus elementos e a adoção de formas puras e geométricas. Daí decorreu todo o projeto do Palácio e o aproveitamento da conformação local, de maneira a criar no nível das avenidas que o ladeiam uma monumental esplanada e sobre ela fixar as cúpulas que deviam hierarquicamente caracterizá-lo. (OSCAR NIEMEYER, 1960).

\subsubsection{O Palácio da Alvorada}

O Palácio da Alvorada inaugurado em 30 de junho de 1958 é um monumento modernista da arquitetura brasileira, projetado por Oscar Niemeyer e calculado pelo engenheiro Joaquim Cardozo, está localizado numa área que divide o Lago Paranoá em Lago Sul e Lago Norte, o qual abriga a Residência Oficial do Presidente da República.

Possui uma área de $13.400 \mathrm{~m}^{2}$, com a fachada formada por pilares que possuem uma leveza arquitetural e estrutural, dando origem ao símbolo e emblema da cidade, presente no Brasão do Distrito Federal. 
Como se pode observar na Figura 4, a volumetria central, recuada, revestida por pano de vidro e ocultando os elementos de sustentação, traz uma sensação de estar reduzindo a altura perceptível da obra contribuindo para dar uma maior leveza ao monumento. Além dessa ala central, dividida em três pavimentos, a residência presidencial conta com um anexo de serviço e uma capela.

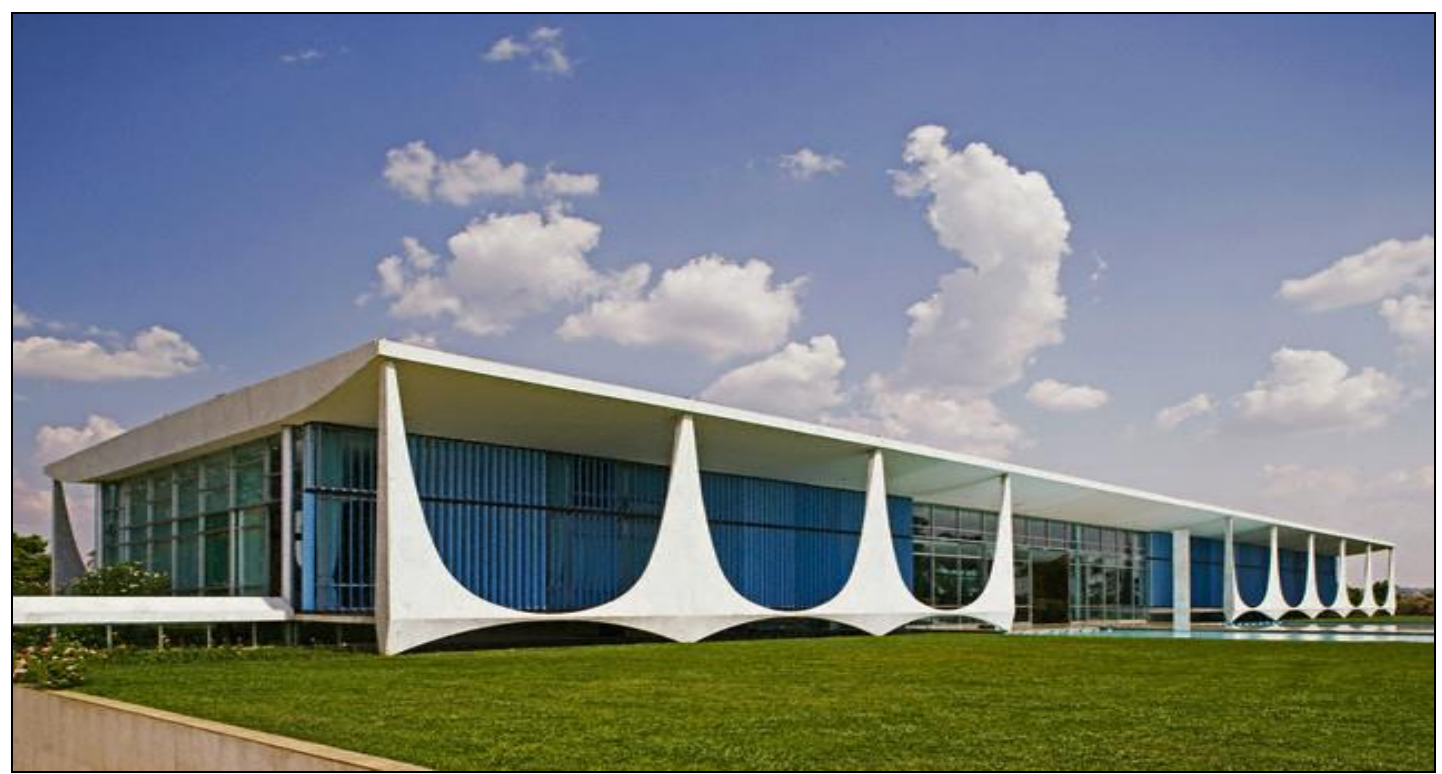

Figura 4 - O Palácio da Alvorada -

Disponível em: < http://vemviverbrasilia.blogspot.com.br/2011/08/palacio-da-alvorada.html >. Acesso em: $14 / 01 / 2017$

De acordo com Vasconcelos (1992) o núcleo principal do Palácio da Alvorada tem dimensões em planta de $110 \mathrm{~m}$ por $30,5 \mathrm{~m}$, com pilares das fachadas espaçados $10 \mathrm{~m}$ no sentido longitudinal e $30 \mathrm{~m}$ no sentido transversal. Esses pilares da fachada ou aparentes recebem somente cargas oriundas da laje da cobertura e a do piso avarandado, já os pilares ocultos ou internos suporta a maior parcela de carga.

\subsubsection{O Palácio do Planalto}

Situado na Praça dos Três Poderes, o Palácio do Planalto foi inaugurado em 21 de abril de 1960, juntamente com a inauguração de Brasília e marca a história brasileira por simbolizar a transferência da capital federal para o centro do país, promovido no governo de Juscelino Kubitscheck.

O projeto arquitetônico de Oscar Niemeyer (1960) impressiona pela pureza de suas linhas com o predomínio de traços horizontais e efeito plástico audacioso. Como mostra a

Figura 5, a beleza do prédio, está nas colunas, definidas pelo arquiteto de "serem leves como penas pousando no chão". 


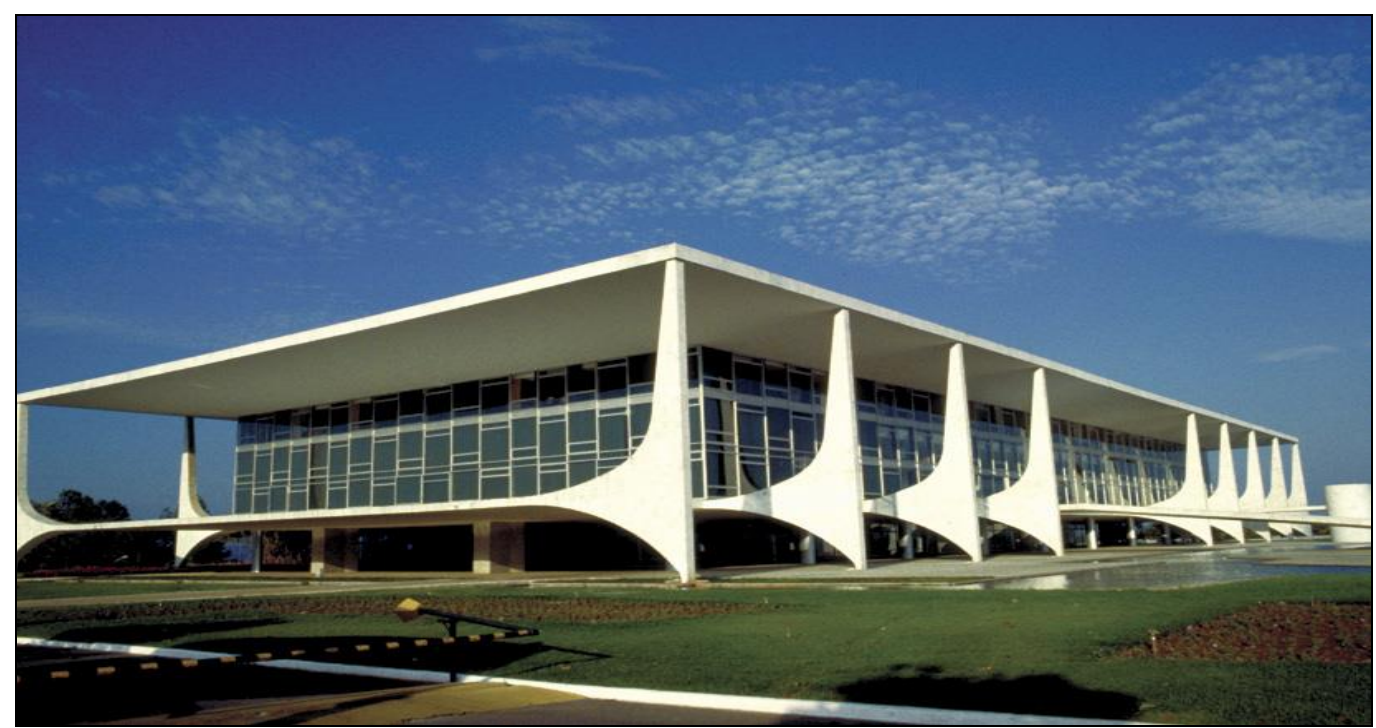

Figura 5 - O Palácio do Planalto -

Disponível em: < http://www.copa2014.gov.br/sites/default/files/palacio-do-planalto_cristiano-mascaro2006_820.jpg >. Acesso em: 14/01/2017

Vasconcelos (1992) destaca que o Palácio possui quatro níveis e seu volume é vedado por caixilhos de vidro, onde tem o prédio recuado em relação à cobertura sendo rodeado por uma galeria. A fachada principal predomina a rampa, que dá acesso ao salão nobre, onde se realiza festa e recebe as visitas estrangeiras. Os pilares possuem um espaçamento de 12,5 m e na parte central, local da rampa, tem um espaçamento de $37,5 \mathrm{~m}$. Onde a partir da eliminação de dois pilares, tornou a entrada mais imponente. Já na direção perpendicular à fachada, a distância entre os pilares externos e internos é de 11,0 m.

Em Vasconcelos (1992) o engenheiro Joaquim Cardozo, responsável pelo cálculo estrutural, argumenta que devido ao elemento ser tão reduzido, dimensionou a seção no pilar, na base e no topo, para que somente o aço resistisse ao esforço, dando ao concreto a função de proteger e garantir a posição das armaduras. E assim, como no Palácio da Alvorada, as cargas nos pilares externos recebem a reação da laje de cobertura e mais o peso próprio.

\subsubsection{O Supremo Tribunal Federal - STF}

Localizado na Praça dos Três Poderes, o STF foi projetado em 1958, pelo arquiteto Oscar Niemeyer e em 2007 teve sua inscrição no livro do tombo feito pelo Instituto do Patrimônio Histórico, Artístico e Nacional - IPHAN.

O Supremo Tribunal Federal e o Palácio do Planalto são edifícios bem parecidos, porém, possuem alguns detalhes que os fazem diferentes entre si. As colunas são semelhantes, parecem velas de uma jangada e são revestidas em mármore branco. Ambos os 
edifícios parecem estar suspensos do chão, a diferenciação está na altura em que a coluna eleva o prédio.

O edifício é apoiado pelos pilares laterais, é levemente afastado do chão, conferindo a leveza e plasticidade. Compondo o cenário do STF, uma estátua de Alfredo Ceschiatti, A Justiça, encontra-se na frente do edifício sede, como mostra na Figura 6.

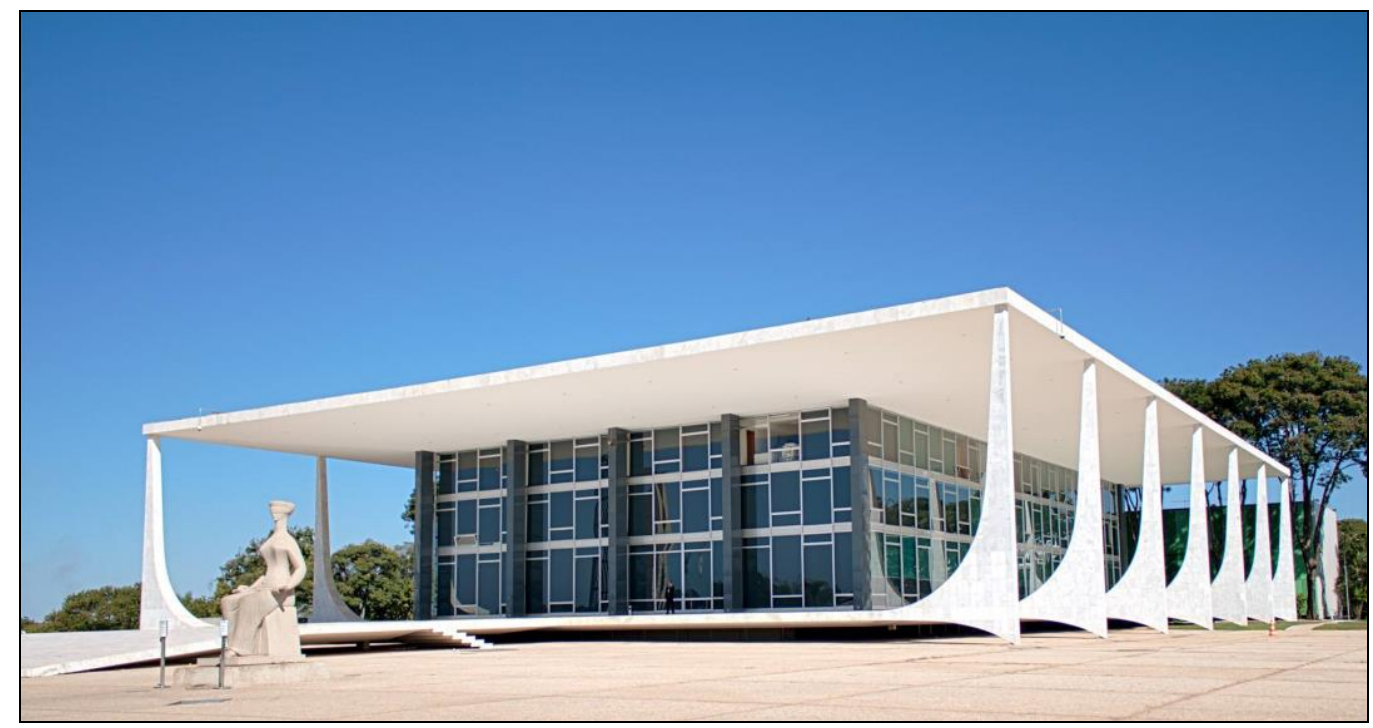

Figura 6 - Supremo Tribunal Federal -

Disponível em: < http://www.cidadebrasilia.com.br/turismo/image/interest/mainImage/2000/supremotribunal-federal.jpg >. Acesso em: 14/01/2017

Oscar Niemeyer (1960) afirmou que "A singeleza do projeto e as proporções relativamente reduzidas deste edifício não impediram que o partido adotado lhes conferisse as características de dignidade e nobreza reclamadas, características essas que as galerias externas acentuavam convenientemente".

\subsubsection{O Tombamento}

Segundo Gorgulho (2012) em 1987, com 27 anos de construída, Brasília já como ícone do urbanismo de Lúcio Costa e da arquitetura moderna de Oscar Niemeyer, tinha crescido em número de habitantes, em desenvolvimento econômico, social e cultural. Nesse período é reconhecida pela UNESCO como Patrimônio Cultural da Humanidade. O conjunto urbanístico e arquitetônico de Brasília, construído a partir do Plano Piloto de Lúcio Costa, foi inscrito no livro de tombo histórico pelo IPHAN em 14 de março de 1990. Porém, a busca desses títulos e reconhecimentos levaram certo tempo, sendo usados vários procedimentos para sua aprovação. 
Ainda segundo Gorgulho (2012) a busca pelo título teve início em 1986, por iniciativas do então governador, José Aparecido de Oliveira, onde é enviado à UNESCO o documento da inscrição de Brasília como Patrimônio Cultural da Humanidade:

Considerando que Brasília já nasceu capital e dentro de uma concepção monumental de espaço, o papel do testemunho histórico de seu tempo lhe é inerente. A preservação dessa evidência baseia-se tanto sobre sua condição de cidade inteiramente nova quando sobre o fato de que ela traduz plenamente os princípios do movimento da arquitetura moderna, expressa na Carta de Atenas, são alguns trechos do dossiê para a inscrição de Brasília. (GORGULHO, 2012).

Gorgulho (2012) aborda que em 7 de dezembro de 1987, na $11^{\circ}$ reunião do Comitê Internacional de Monumentos e Sítios (ICOMOS) junto ao centro do Patrimônio Mundial da UNESCO, a inscrição de Brasília é analisada e aprovada por todos os membros, e finalmente em 11 de dezembro do mesmo ano, a UNESCO confere o diploma que oficializa o título de Patrimônio Cultural da Humanidade.

Anos seguintes, a maioria das obras do arquiteto Oscar Niemeyer foram inscritas no livro de tombo pelo IPHAN, devido ao arrojo estético e estrutural como: a Catedral, o Congresso Nacional, o Palácio do Planalto, o Palácio da Alvorada, o Itamaraty, o Supremo Tribunal Federal, dentre outras. Algumas dessas obras foram objetos de estudo de dissertações de mestrado do Programa de Pós-Graduação em Estruturas e Construção Civil (PECC), da Universidade de Brasília - UnB.

No entanto, cabe a UNESCO acompanhar a evolução da cidade e delimitar sua gestão de acordo com as recomendações do Comitê do Patrimônio da Humanidade, e ao IPHAN cabe tomar iniciativas para proteger e promover os bens culturais do país, assegurando sua permanência e usufruto para as gerações presentes e futuras.

\subsection{PESQUISAS REALIZADAS SOBRE OS MONUMENTOS DE BRASÍLIA}

\subsubsection{Pessoa (2002)}

Pessoa (2002) estudou a história, a concepção, a execução da Catedral de Brasília e avaliou as condições da estrutura através da utilização de programas computacionais (SAP2000 e ANSYS) e comparou os resultados com os valores informados no projeto original, além de quantificar o grau de deterioração das estruturas de concreto pela metodologia GDE/UnB e adotar propostas de manutenção para a extensão da vida útil do monumento histórico. 
A Catedral de Brasília, projetada pelo arquiteto Oscar Niemeyer e calculada por Joaquim Cardozo, locada em uma praça autônoma próxima à praça dos três poderes, foi executada entre 1959 e 1970, onde na fase inicial foi construída a estrutura da nave, e na fase final, feita a implementação do espelho d'agua, o batistério e o campanário, como mostra na Figura 7.

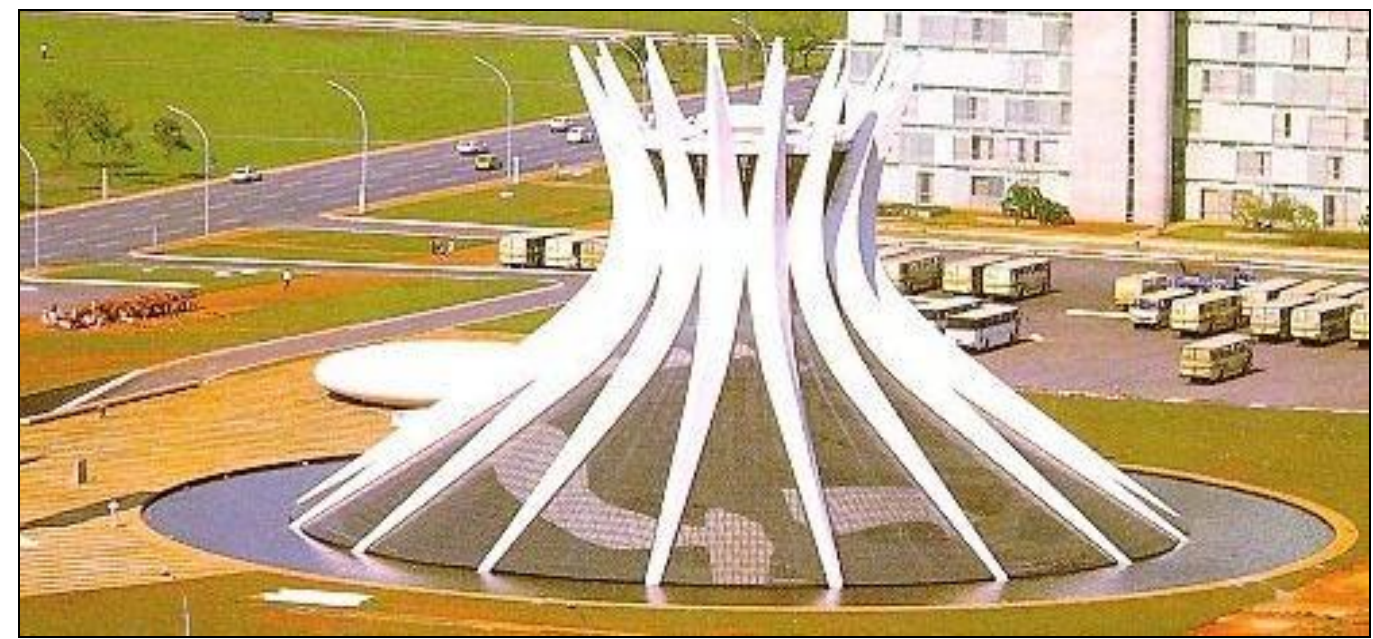

Figura 7 - Conjunto da Catedral de Brasília - Pessoa (2002)

Oscar Niemeyer nessa incrível obra de arte valoriza a forma escultural e usa uma escala monumental, destacando audácia e a simplicidade da planta baixa, além da complexidade da solução estrutural e volumetria do edifício. Possui uma planta circular com $60 \mathrm{~m}$ de diâmetro, onde se erguem 16 pilares de seção parabólica, interligados por uma coroa circular que absorve os esforços de compressão, e com altura de $10 \mathrm{~m}$.

Pessoa (2002) observou que o anel inferior de tração (deslocamentos positivos, área vermelha) foi concebido de forma a permitir a transmissão exclusiva de esforços verticais aos blocos de fundação e o anel superior absorvendo os esforços de compressão (deslocamentos negativos, área azul), como mostra a Figura 8.
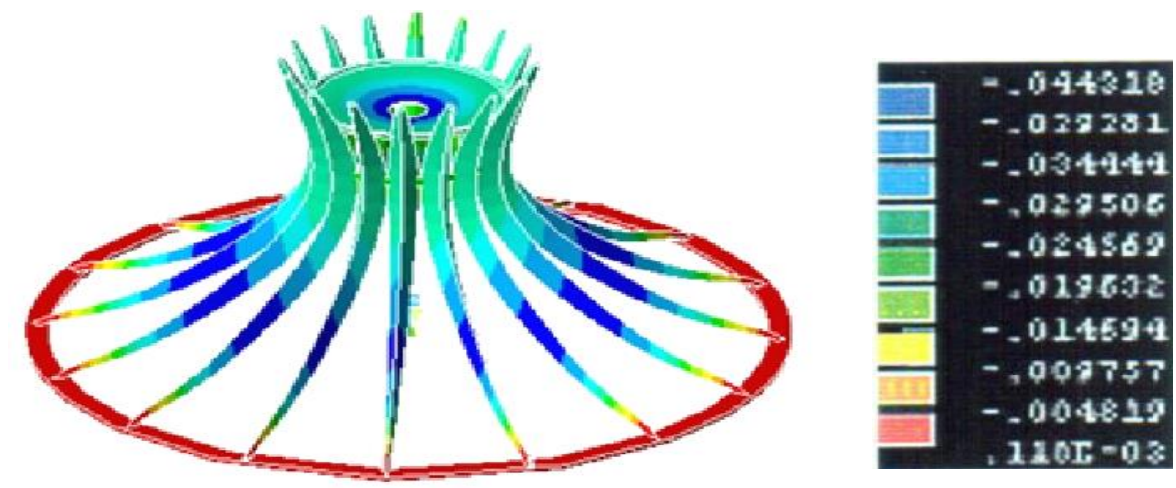

Figura 8 - Deslocamentos, na direção Z (metros), da estrutura da Catedral de Brasília, (Programa ANSYS) - Pessoa (2002) 
Através da utilização do programa ANSYS o autor obteve os deslocamentos máximos na direção Z, que foram aproximadamente $4,5 \mathrm{~cm}$ nos pilares e na laje de cobertura, como podemos observar na Figura 8.

A modelagem no SAP2000 foi feita em Frame (barras) e Shell (cascas), já no ANSYS, o modelo é considerado como um corpo sólido único, uma espécie de volume para representar cada elemento, que estão unidos. Em ambos os modelos foram adotados uma sobrecarga de $0,5 \mathrm{KN} / \mathrm{m}^{2}$ na laje da cobertura e na laje do anel superior do anel de tração. Além do peso dos vitrais, como carga distribuída ao longo do segmento de cada pilar, e considerando o concreto como material isotrópico, com resistência a compressão $\mathrm{f}_{\mathrm{ck}}=21$ MPa e com módulo de elasticidade $E=32 \times 10{ }^{6} \mathrm{kN} / \mathrm{m}^{2}$.

Pessoa (2002) também fez uma comparação dos resultados obtidos nas ferramentas computacionais, como mostra na Tabela 1 , onde verificou que os resultados obtidos das reações de apoio nos modelos SAP2000 e ANSYS barra são parecidos, caracterizando, assim uma distribuição de esforços consistente. Já a reação de apoio no ANSYS sólido é cerca de $15 \%$ menor que as reações dos outros modelos, o autor explica, que esta diferença de resultados se deu pela não consideração do anel inferior, sobrecargas da cobertura e anjos, no modelo sólido.

Tabela 1- Reações de apoio nos modelos dos programas SAP 2000 e ANSYS Pessoa (2002)

\begin{tabular}{|c|c|c|}
\hline Modelo 3D & $\begin{array}{c}\text { Reação nos Apoios } \\
(\text { KN) }\end{array}$ & $\begin{array}{c}\text { Diferença \% em relação ao } \\
\text { Projeto Original }\end{array}$ \\
\hline SAP 2000 & 1572 & $25 \%$ \\
\hline ANSYS Barra & 1523 & $27 \%$ \\
\hline ANSYS sólido & 1296 & $38 \%$ \\
\hline Projeto Original & 2100 & $0 \%$ \\
\hline
\end{tabular}

Note na Tabela 2 que os deslocamentos nos modelos 2D são bem maiores que os obtidos nos modelos 3D, exceto o ANSYS Sólido. As distorções de resultados entre o SAP2000 e o ANSYS, podem ser explicadas pelas condições de contorno, do tipo de elementos finitos adotados, das sobrecargas consideradas e da diferenciação na formulação matemática. Os valores de esforços normais e momentos fletores também foram próximos nos dois programas computacionais utilizados. 
Tabela 2 - Valores máximos e deslocamentos nos modelos 2D e 3D - Pessoa (2002)

\begin{tabular}{|c|c|c|}
\hline \multirow{2}{*}{} & \multicolumn{2}{|c|}{ Resultante de deslocamento (cm) } \\
\cline { 2 - 3 } & Modelos 2D & Modelos 3D \\
\hline SAP 2000 - Barra & 12 & 8,5 \\
\hline ANSYS - Sólido & 4,3 & 5,9 \\
\hline ANSYS - Barra & 11,1 & 4,9 \\
\hline ANSYS - Sólido (original) & 5,8 & - \\
\hline
\end{tabular}

O autor utilizou a metodologia GDE/UnB para quantificar o grau de deterioração da estrutura, onde foi realizada uma vistoria no edifício com o intuito de avaliar o estado atual da estrutura e identificar as patologias presente no monumento. A Tabela 3 mostra o grau de deterioração dos elementos obtidos, onde observou que o nível mais crítico de deterioração foi no espelho d'água, que mesmo depois de ter passado por duas intervenções de cunho estético, continuava a apresentar infiltrações e vazamento, devido à má disposição das juntas de dilatação, necessitando de um reparo imediato.

Tabela 3 - Grau de deterioração da estrutura (Gd) e prazo para intervenção - Pessoa (2002)

\begin{tabular}{|c|c|c|c|}
\hline Estrutura & Gd & Nível de deterioração & Prazo para Intervenção \\
\hline Nave & 15 & Nível Médio (15-40) & Médio Prazo- máximo de 2 anos \\
\hline Espelho d'água & 68 & Nível Crítico (> 60) & Intervenção Imediata \\
\hline Batistério & 37 & Nível Médio (15-40) & Médio Prazo- máximo de 2 anos \\
\hline Campanário & 04 & Nível Baixo (0-15) & Manutenção Preventiva \\
\hline
\end{tabular}

Por fim, Pessoa (2002) propõe uma proposta de manutenção para a Catedral, onde estabelece um programa de intervenções periódicas para todos os componentes do conjunto de acordo com as condições ambientais e de carregamento do edifício.

De acordo com os intervalos de tempo para a realização de inspeções, que são baseados na metodologia da Federação Internacional da Protensão para Estruturas de Concreto Armado e Protendido - FIB (1988), o monumento se enquadra na Classe 1, condições ambientais e de carregamento normais, ficando estabelecidas inspeções rotineiras a cada dez anos, intercaladas com inspeções extensivas no mesmo período de tempo.

Entretanto, devido à importância histórica da obra, o autor sugere reduzir esse intervalo para seis anos. Além de uma inspeção rotineira ou extensiva na estrutura a cada três anos. O autor ainda elabora um Check List para cada elemento da obra, caracterizando os pontos críticos, como fissuras, vestígios de corrosão, etc., através de planilha, fotos ou croquis, a fim de ajudar no monitoramento e na preservação do monumento. 


\subsubsection{Santos Jr (2004)}

Santos Jr (2004) estudou a história, a concepção, a execução do Palácio Itamaraty e avaliou as condições da estrutura através da utilização de programas computacionais SAP2000 (1995) e comparou os resultados com os valores informados no projeto original, além de quantificar o grau de deterioração das estruturas de concreto pela metodologia GDE/UnB e adotar propostas de manutenção para a extensão da vida útil do monumento histórico.

O Palácio do Itamaraty, conjunto que abriga o Ministério das Relações Exteriores foi construído no período de 1963 a 1970, e é uma verdadeira obra prima estando localizada ao lado do Congresso Nacional e frontal ao Palácio da Justiça, no início do conjunto de edifícios da Esplanada dos Ministérios.

Como podemos observar na Figura 9, o edifício tem a forma quadrada em planta, com 84 $\mathrm{m} \times 84 \mathrm{~m}$ e altura total de $17,56 \mathrm{~m}$, sendo $4,27 \mathrm{~m}$ no subsolo, e fachadas todas em concreto aparente, cada uma delas é constituída por linhas de 15 pilares, distantes 6,00 m entre si, com um fechamento superior de cada dois pilares em arcos ligados à cobertura. As vigas internas têm altura máxima de 1,2 m e vãos livres de $30 \mathrm{~m}$ e $36 \mathrm{~m}$, uma arrojada concepção para estruturas de concreto armado, onde exigiu a adoção de contra flechas nas vigas, para contrabalançar a deformação elevada na retirada dos escoramentos.

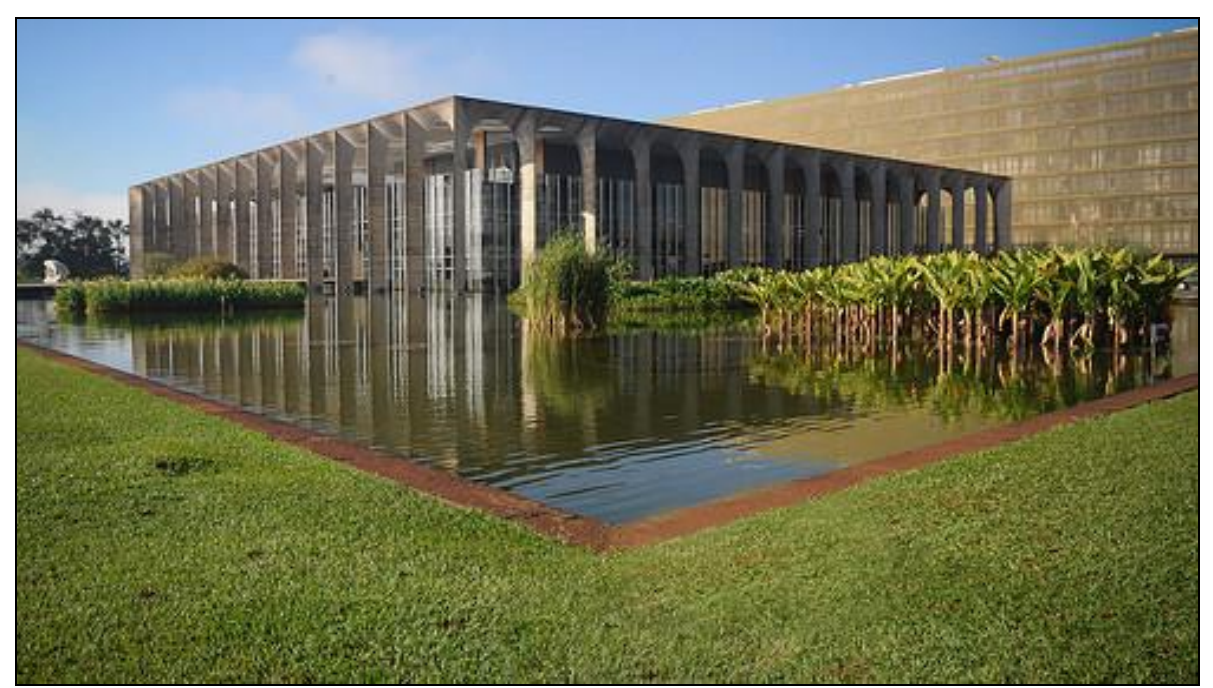

Figura 9 - Palácio Itamaraty em Brasília -

Disponível em: < https://farm8.staticflickr.com/7562/16023452196_512ddc38c9.jpg>. Acesso em: $17 / 01 / 2017$

A obra denota o gênio de seus criadores, o arquiteto Oscar Niemeyer e engenheiro estrutural Joaquim Cardozo, e a ousadia, a qualidade dos profissionais de projeto e construção do Brasil, compreendendo três prédios, com uma área construída total aproximada de $75.000 \mathrm{~m}^{2}$. 
Santos Jr (2004) estudou e avaliou as condições da estrutura através da utilização de programas computacionais SAP2000 (1995), seguindo a geometria do projeto original, utilizou o elemento finito frame para representar as barras unidimensionais - vigas e pilares, demonstrado na Figura 10.

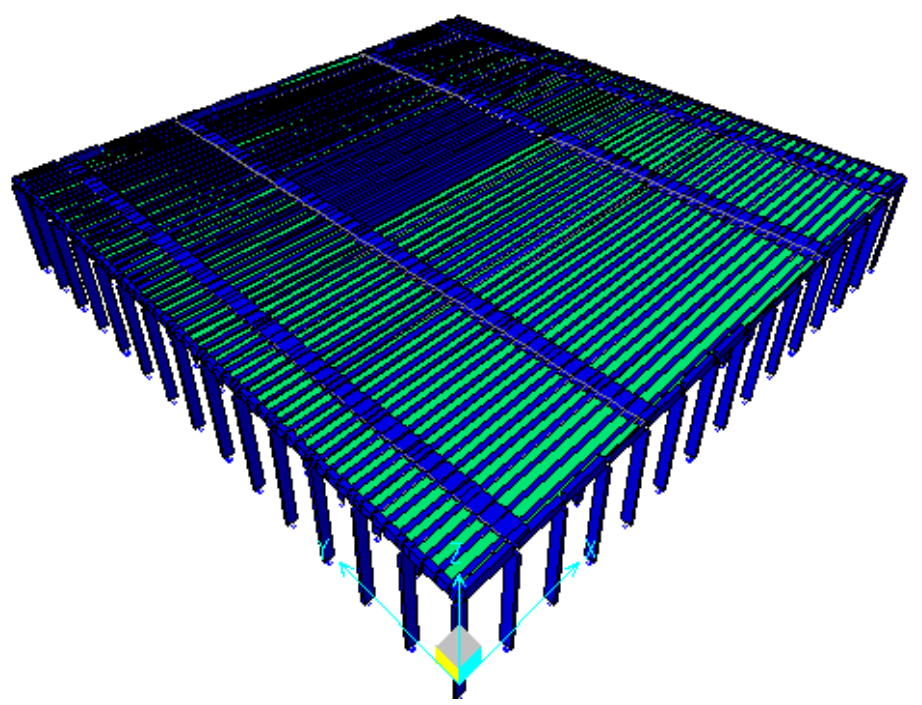

Figura 10 - Modelação volumétrica na plataforma CAD - Santos Jr (2004)

Nesse modelo, foram idealizados dois pórticos planos: o primeiro na direção Leste-Oeste, na Figura 11, denominado Pórtico A, onde é constituído por vigas de $36 \mathrm{~m}$ e $30 \mathrm{~m}$ de vão, que se apoiam no Pórtico B, formado pelos pilares e vigas na direção Norte-Sul, na Figura 12. Foram encontrados os esforços máximos, como cortante e momentos fletores, e a partir daí feito o dimensionamento das estruturas de concreto e comparados com os valores do projeto original, onde foram encontrados valores das reações da fundação muito próximos ao projeto estrutural de Joaquim Cardozo.

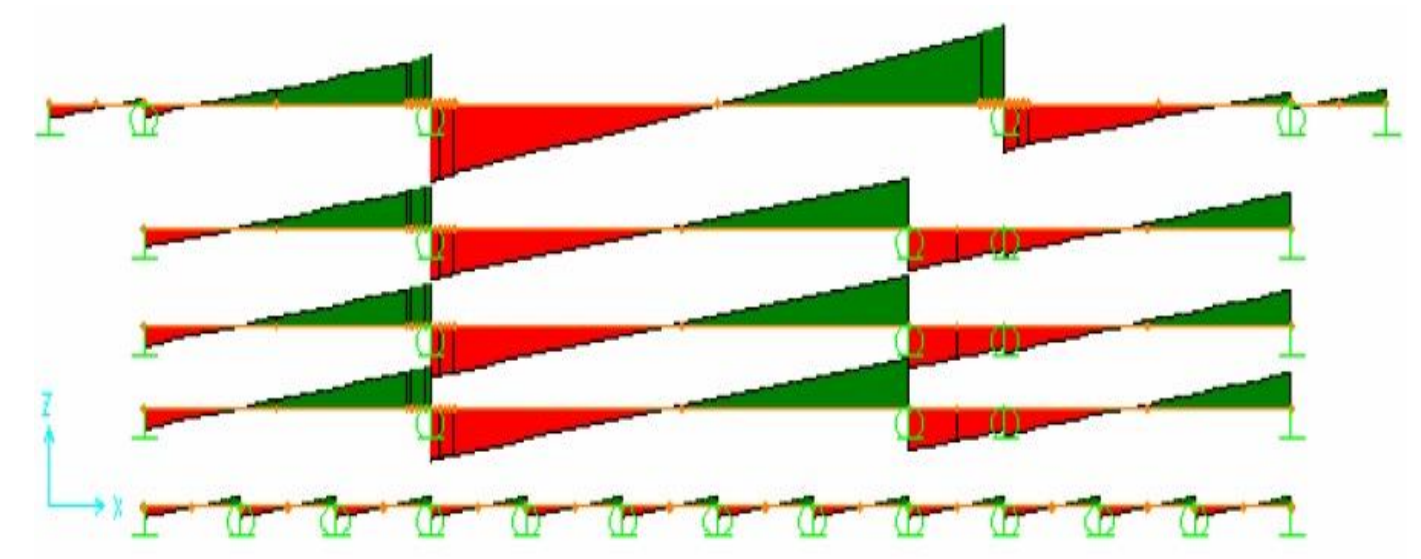

Figura 11 - Diagrama de forças cortante no pórtico A, direção leste-oeste, SAP2000 Santos Jr (2004) 


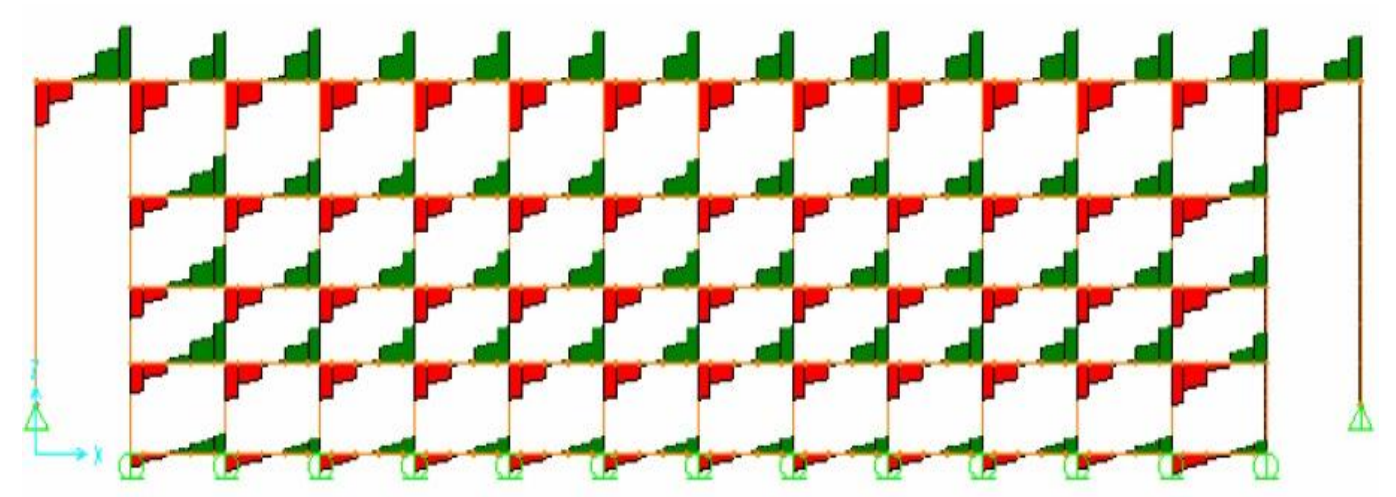

Figura 12 - Diagrama de forças cortante no pórtico B, direção norte-sul, SAP2000 - Santos Jr (2004)

A modelagem no SAP2000, com suas devidas ações consideradas, obteve-se os diagramas de momentos fletores dos pórticos A e B. Nas vigas, o momento positivo máximo foi de $855 \mathrm{KNm}$ e o momento negativo de $619 \mathrm{KNm}$. Já nos pilares o momento máximo foi de $305 \mathrm{KNm}$, ao topo dos pilares dos arcos da fachada no pórtico B. Os esforços cortantes máximo nas vigas foram $166 \mathrm{KN}$ no pórtico A e de $846 \mathrm{KN}$ no pórtico B. Já nos pilares os esforços cortantes máximo foram de $27 \mathrm{KN}$.

A partir desses esforços e os momentos é feito um dimensionamento da armadura do elemento de concreto, seguindo a norma ABNT NBR 6118:2003 e comparando os resultados obtidos com o projeto original.

A Tabela 4 mostra que as armaduras calculadas para os pilares de acordo com a norma, são muito pouco inferiores, com pequena diferença aos cálculos do projeto original, mostrando a confiabilidade do projeto feito anos atrás, sem o uso das ferramentas computacionais.

Tabela 4 - Comparação das armaduras calculadas pela ABNT NBR 6118:2003, com o projeto original (bitolas em polegadas) - Santos Jr (2004)

\begin{tabular}{|c|c|c|c|}
\hline Pilares & Calculada & Original & Calculada/Original (\%) \\
\hline P2- Seção 1 & $20 \phi 3 / 4 ”$ & $20 \phi 3 / 4 ”$ & -10 \\
\hline P2- Seção 2 & $22 \phi 7 / 8 ”$ & $22 \phi 7 / 8 ”$ & 0 \\
\hline P2- Seção 3 & $30 \phi 1 ”$ & $32 \phi 1 ”$ & -7 \\
\hline P2- Seção 4 & $33 \phi 1 ”$ & $35 \phi 1 ”$ & -6 \\
\hline Pilar arco (modeloI) & $42 \phi 1 / 2 ”$ & $44 \phi 1 / 2 ”$ & -5 \\
\hline Pilar arco (modeloII) & $45 \phi 1 / 2 ”$ & $44 \phi 1 / 2 ”$ & +2 \\
\hline
\end{tabular}

Verifica- se na Tabela 5 que os valores de reações verticais na fundação encontrados no modelo são muito próximos dos originais, mostrando que os resultados são compatíveis. Porém, o cálculo original está mais a favor da segurança, demonstrando a qualidade do projeto, observa-se que as diferenças dos resultados são dadas em porcentagem. 
Tabela 5 - Comparação cargas de fundação SAP2000 e projeto original - Santos Jr (2004)

\begin{tabular}{|c|c|c|c|}
\hline Pilar & SAP 2000 (KN) & Proj. Original (KN) & $\begin{array}{c}\text { Diferença em } \\
\text { Porcentagem (\%) entre } \\
\text { SAP2000 x Proj. Original }\end{array}$ \\
\hline Parc & 814 & 940 & $-13,40$ \\
\hline P1 & 3400 & 3800 & $-10,52$ \\
\hline P2 & 5744 & 5800 & $-0,01$ \\
\hline P3 & 5532 & 5800 & $-4,62$ \\
\hline P4 & 5509 & 5800 & $-5,02$ \\
\hline P5 & 5503 & 5800 & $-5,12$ \\
\hline P6 & 5507 & 5800 & $-5,05$ \\
\hline
\end{tabular}

A Tabela 6 mostra um comparativo entre as flechas encontradas no modelo feito no SAP2000 e o cálculo desenvolvido de acordo com ABNT NBR 6118:2003, o que confirma a necessidade de contra-flechas nas vigas do pórtico com vãos, entre 30 m a 36 m.

Tabela 6 - Comparação das flechas no SAP2000 e a ABNT NBR 6118:2003 Santos Jr (2004)

\begin{tabular}{|c|c|c|c|}
\hline \multirow{2}{*}{$\begin{array}{c}\text { Viga } \\
(\mathbf{s e c ̧ o ̃ e s})\end{array}$} & $\begin{array}{c}\text { Deslocamento vertical } \\
\text { SAP2000 } \\
\left(\mathbf{c m}^{2}\right)\end{array}$ & \multicolumn{2}{|c|}{ ABNT NBR 6118:2003 } \\
\cline { 3 - 4 } & 14 & $\begin{array}{c}\text { Flecha } \\
\text { Imediata }(\mathbf{c m})\end{array}$ & Flecha Final $(\mathbf{c m})$ \\
\hline $20 \times 120$ & 15 & 12 & 22 \\
\hline $20 \times 70$ & 13 & 24 \\
\hline
\end{tabular}

Um programa de inspeções foi realizado visando elaborar um diagnóstico de sua situação física atual, com a classificação e quantificação dos danos da estrutura de concreto, por meio da utilização da metodologia GDE/UnB. A Tabela 7 mostra os resultados obtidos por meio de cálculos e critérios de avaliação contidas na metodologia, demonstrando o nível de deterioração da estrutura e o prazo de intervenção.

Tabela 7 - Grau de deterioração de cada elemento (Gde), das famílias de elementos (Gdf) e da estrutura principal do prédio (Gd) - Santos Jr (2004)

\begin{tabular}{|c|c|c|c|c|}
\hline & $\begin{array}{c}\text { Escada } \\
\text { Helicoidal }\end{array}$ & $\begin{array}{c}\text { Vigas } \\
\text { Periféricas }\end{array}$ & $\begin{array}{c}\text { Vigas- } \\
\text { Cobertura }\end{array}$ & $\begin{array}{c}\text { Lajes- } \\
\text { Cobertura }\end{array}$ \\
\hline Gde & 12 & 48 & 6 & 6 \\
\hline Gdf & - & 53 & 6 \\
\hline Gd & 25 & Nível de deterioração da estrutura: médio= (15 a 40) \\
& & \multicolumn{2}{|c|}{ Prazo de intervenção: no máximo 2 anos } \\
\hline
\end{tabular}


Verifica-se na Tabela 7, um nível de deterioração classificada como médio, no qual recomenda-se uma intervenção no prazo de dois anos. Além disso, é possível constatar que as vigas periféricas sugerem uma intervenção imediata, pois foram encontradas armaduras expostas na fachada leste, próximas de regiões com alta umidade relativa do ar. O autor também propõe um reparo nas escadas devido à corrosão do aço em algumas partes dos elementos. Os pilares das fachadas do edifício apresentaram um nível de deterioração baixo (0 a 15), indicando apenas manutenções rotineiras e limpeza de manchas escuras no concreto aparente dos arcos.

No entanto, os elementos que formam a passarela apresentaram um nível de deterioração crítico como mostra a Tabela 8 , onde em alguns pilares foram observadas fissuras que excedam o limite estipulado pela norma, devido à sobrecarga excessiva. No programa de manutenção recomenda-se uma avaliação mais profunda dos pilares das passarelas, analisar a origem dos danos e prever uma recuperação imediata.

Tabela 8 - Grau de deterioração de cada elemento (Gde), das famílias de elementos (Gdf) e das estruturas das passarelas e do lago circundante - Santos Jr (2004)

\begin{tabular}{|c|c|c|c|c|c|c|c|c|c|c|c|c|c|c|}
\hline & \multicolumn{5}{|c|}{ Vigas das Passarelas } & \multicolumn{2}{|c|}{$\begin{array}{l}\text { Pilares das } \\
\text { Passarelas }\end{array}$} & \multicolumn{7}{|c|}{ Lajes das Passarelas } \\
\hline & 1 & 2 & 3 & 4 & 5 & $1 \mathrm{e} 2$ & outras & 1 & 2 & 3 & 4 & 5 & 6 & 7 \\
\hline Gde & 61 & 4 & 4 & 4 & 2 & 110 & 4,8 & 30 & 8 & 24 & 8 & 8 & 8 & 8 \\
\hline Gdf & \multicolumn{5}{|c|}{78} & \multicolumn{2}{|c|}{112} & \multicolumn{7}{|c|}{50} \\
\hline Gd & \multicolumn{5}{|c|}{101} & $\begin{array}{l}\text { dete } \\
\text { Prazo }\end{array}$ & $\begin{array}{l}\text { oração d } \\
\text { le interv }\end{array}$ & estr & tur & : $\mathrm{Cr}_{1}^{1}$ & ico & & & \\
\hline
\end{tabular}

\subsubsection{Moreira (2007)}

Moreira (2007) estudou a história, a concepção, a execução do Palácio da Justiça e avaliou as condições da estrutura através da utilização de programas computacionais AutoCAD 2007 e CAD/TQS 2007 comparando os resultados obtidos com os valores informados no projeto original, e na norma ABNT NBR 6118:2003, além de quantificar o grau de deterioração das estruturas de concreto pela metodologia GDE/UnB e adotar propostas de manutenção para a extensão da vida útil do monumento histórico.

O Palácio da Justiça foi projetado pelo renomado arquiteto Oscar Niemeyer e calculada pelo Escritório Técnico Athur Luiz Pitta (Etalp), recebendo o ministério de justiça em 
1972. O Palácio é formado a partir de uma planta retangular, com $84 \mathrm{~m}$ x $75 \mathrm{~m}$ de lados, com cinco pavimentos e um subsolo. As quatro fachadas têm aparência diversificadas e as envolve um núcleo central, um quadrado perfeito de 61,1 m de lado. Essas fachadas estão recuadas de $7 \mathrm{~m}$ a $11 \mathrm{~m}$ do núcleo, formando o que se chama "avarandado". No terceiro pavimento, existe um jardim interno, com pé direito de 10,1 m e com vigas de cobertura formando um pergolado superior com vãos livres de $18 \mathrm{~m}$ e $32 \mathrm{~m}$. A fachada principal ao sul, apresenta nove semi-arcos interligando os pilares esbeltos, que possuem espaçamento de 6,5 m entre eles. Esses pilares são interligados por seis cascatas em diferentes níveis com estruturas em balanço, além dos espelhos e fontes com jogos d'água e os jardins do paisagista Roberto Burle Marx, conforme Figura 13.

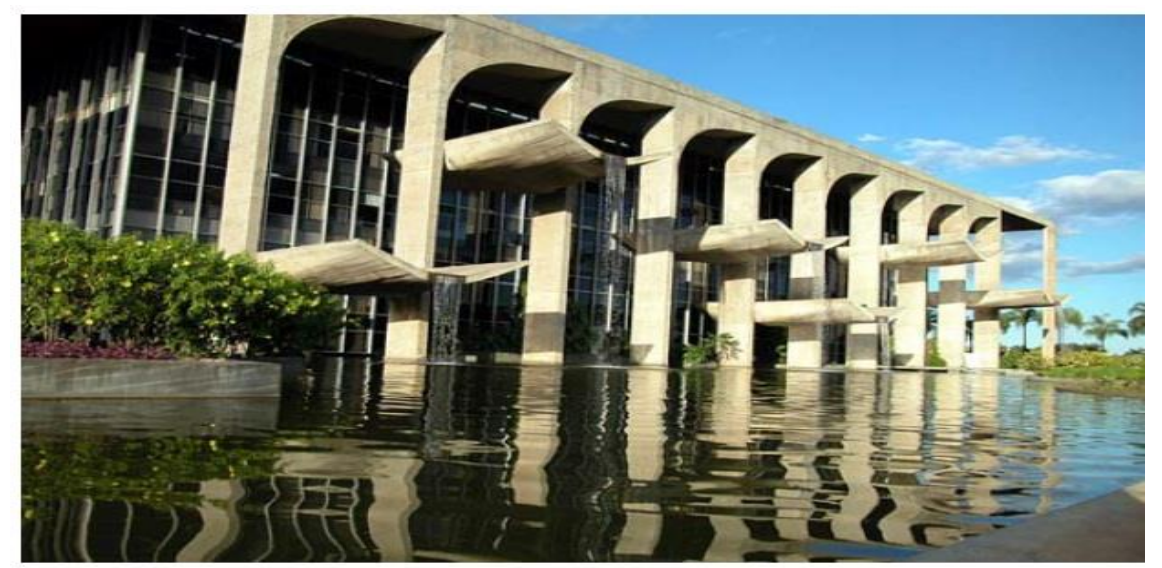

Figura 13 - Palácio da Justiça em Brasília -

Disponível em: < http://www.brasiliafacil.com/wp-content/uploads/palacio-da-justica-brasilia-df.jpg>. Acesso em: 17/01/2017

A solução estrutural adotada no Palácio de Justiça foi lajes nervuradas (grelhas da viga) com vãos de 13 m, vigas e vigas-faixa em concreto armado. As vigas e as nervuras têm altura de $50 \mathrm{~cm}$ e capa da laje (mesa) tem espessura de $6 \mathrm{~cm}$ e $7 \mathrm{~cm}$, e as vigas faixas com largura variando de $85 \mathrm{~cm}$ a $115 \mathrm{~cm}$ e altura de $50 \mathrm{~cm}$. A planta de cobertura tem dimensões de 84,5 m x 75,1 m e se estende até os limites externos das fachadas com o uso de vigas contínuas espaçadas entre eixos $1,30 \mathrm{~m}$. As vigas de cobertura têm seção transversal de $15 \mathrm{~cm}$ x $70 \mathrm{~cm}$ e as vigas do jardim tem seções de 15 x $100 \mathrm{~cm}$.

Moreira (2007) modelou o edifício utilizando o software comercial CAD/TQS 2007 de análise de estruturas de concreto armado, onde idealizou para os pavimentos um modelo de analogia a grelhas (barras-vigas e lajes) para avaliar os deslocamentos produzidos pelas ações verticais e para a análise do comportamento global foi utilizado o modelo de pórtico espacial (vigas, pilares e tirantes) para se obter os esforços devido às ações verticais (peso 
próprio, sobrecargas, etc.) e devido às ações horizontais (vento, empuxo, assimetria, etc.), conforme Figura 14.

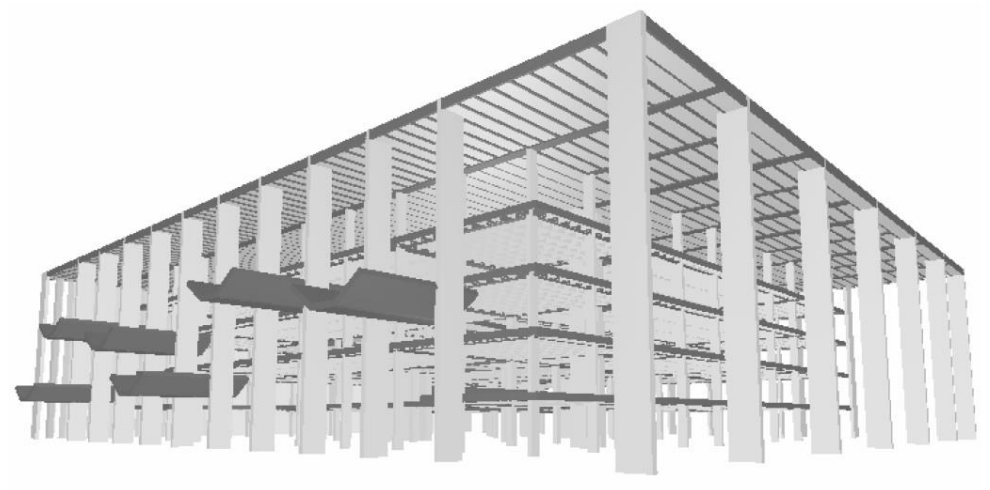

Figura 14 - Perspectiva: estrutura da fachada sul, com as cascatas, e fachada leste, CAD/TQS - Moreira (2007)

O modelo idealizado pelo autor considerou as ações (peso próprio, peso elementos fixos e instalados, carga acidental, vento, etc.) e as combinações das ações, onde a partir da combinação mais desfavorável, foi feita uma verificação dos estados limites de serviços (ELS), analisando os deslocamentos verticais e os deslocamentos horizontais máximos no edifício. Os deslocamentos verticais na laje, no pavimento térreo foram de $-2,51 \mathrm{~cm}$; no $2^{\circ}$ pavimento foi de $-2,98 \mathrm{~cm} \mathrm{e}-2,17 \mathrm{~cm}$; no $3^{\circ}$ pavimento foi de $-2,40 \mathrm{~cm}$ para os vãos de $13 \mathrm{~m} \mathrm{e} \mathrm{no} 4^{\circ}$ e $5^{\circ}$ pavimentos foi de $-2,98 \mathrm{~cm}$ também para os vãos de $13 \mathrm{~m}$, conforme Figura 15.

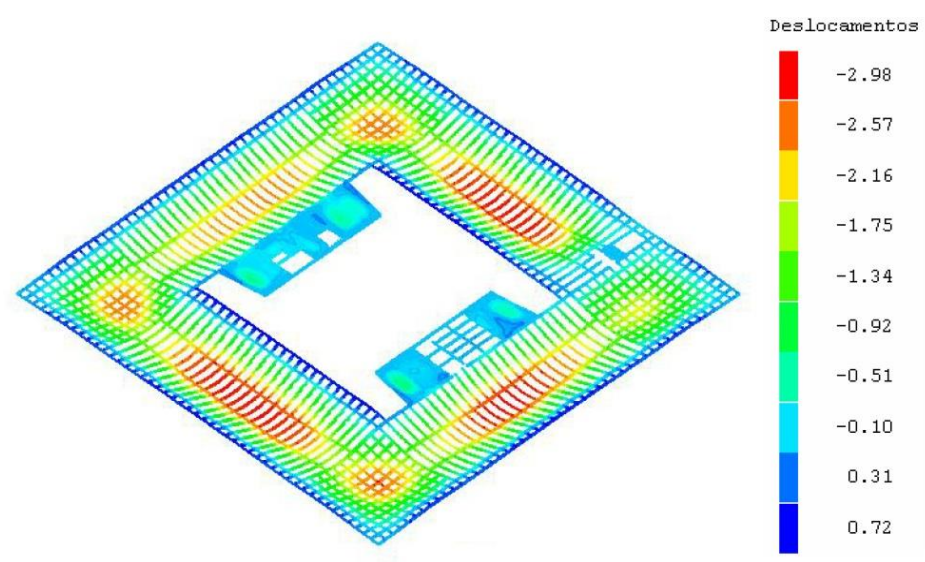

Figura 15 - Deslocamento das estruturas do $4^{\circ}$ e $5^{\circ}$ pavimentos, em cm, CAD/TQS Moreira (2007)

O autor observou que foram adotados contra flechas de 3,0 cm exatamente onde tiveram os maiores deslocamentos verticais, demonstrando a qualidade do projeto feito naquela época. Porém, de acordo com a norma ABNT NBR 6118: 2003 as contra flechas é de "1/350", 
sendo 3,7 cm para os vãos de 13,0 m e os deslocamentos máximos verticais é de 1/250, sendo 5,2 cm para os vãos de 13,0 m.

O projeto original, especificadamente na cobertura, foi adotado contra flechas de $8,0 \mathrm{~cm}$ para as vigas do jardim e 5,0 cm de contra flechas no centro das lajes avarandadas. $\mathrm{O}$ deslocamento vertical das vigas do jardim foi de $-11,38 \mathrm{~cm}$ e as lajes avarandadas de $-4,0$ $\mathrm{cm}$, conforme a Figura 16.

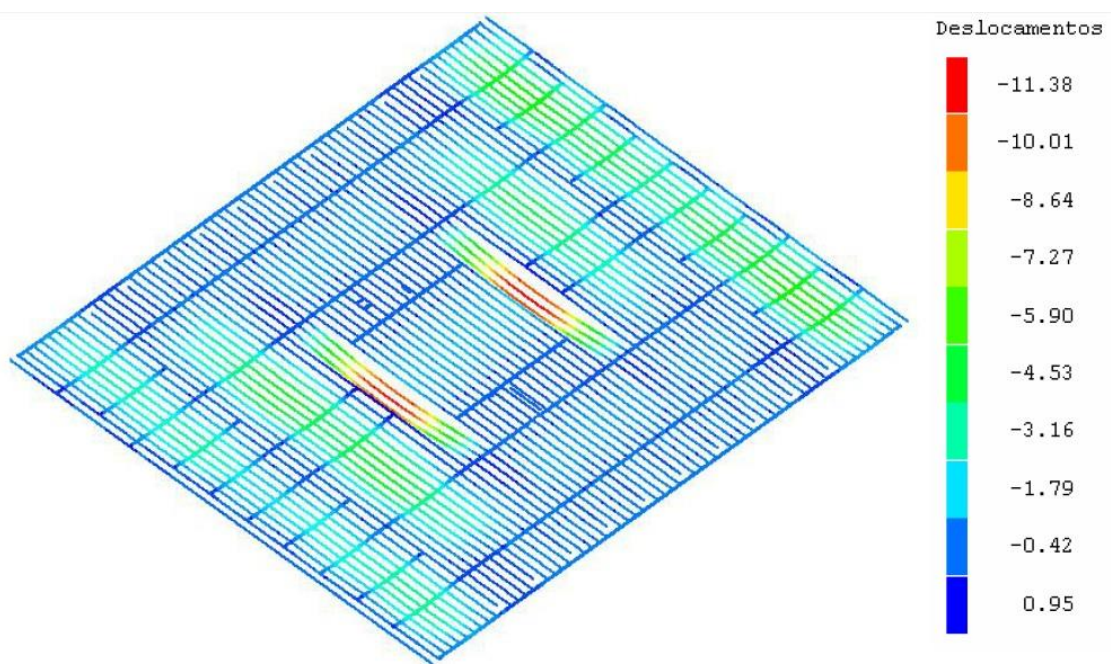

Figura 16 - deslocamentos na cobertura, em cm. CAD/TQS - Moreira (2007)

Para a verificação dos estados limites de deformação excessivas da estrutura, foram levantados os valores de deslocamentos horizontais para o caso com ângulo de incidência do vento de $0^{\circ}$, apresentando deslocamentos de $-0,28 \mathrm{~cm}$ nas lâminas que formam os brises na fachada leste (Figura 17) e a incidência de $90^{\circ}$ apresentando um deslocamento de 0,19 cm (Figura 18). Ambos os atende a norma ABNT NBR 6118:2003, que limita o deslocamento horizontal devido carga acidental em H/1700.

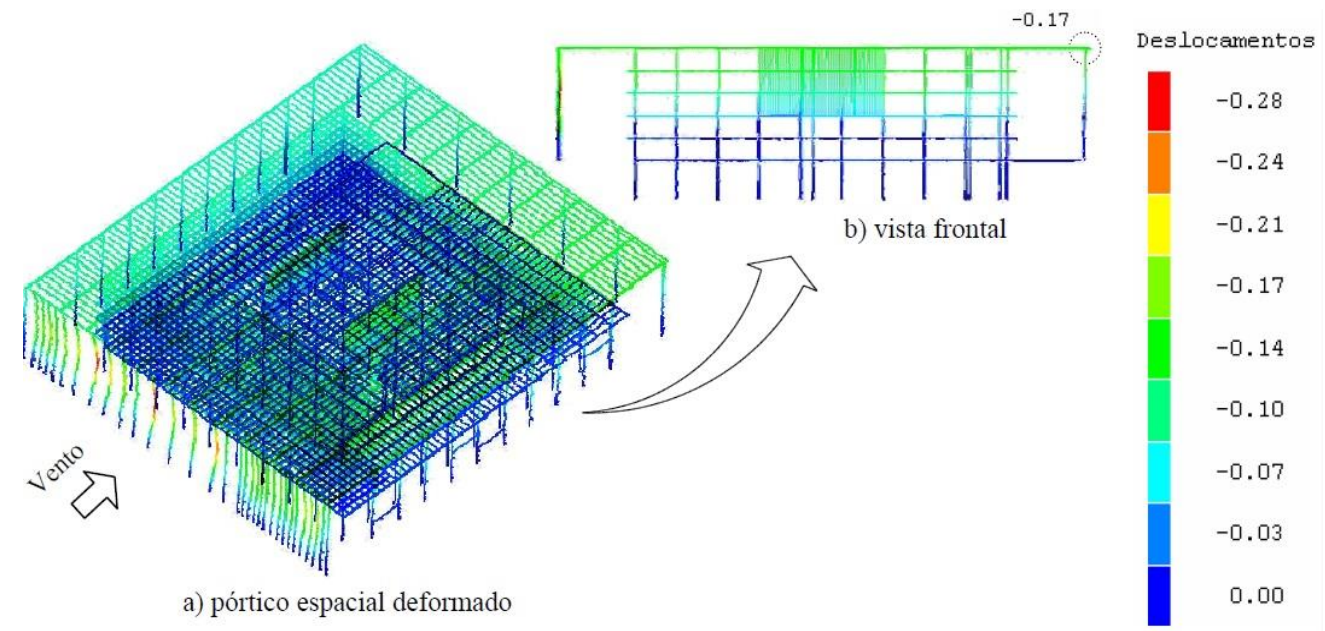

Figura 17 - Deslocamentos horizontais devido ações do vento de incidência de $0^{\circ}$ Moreira (2007) 


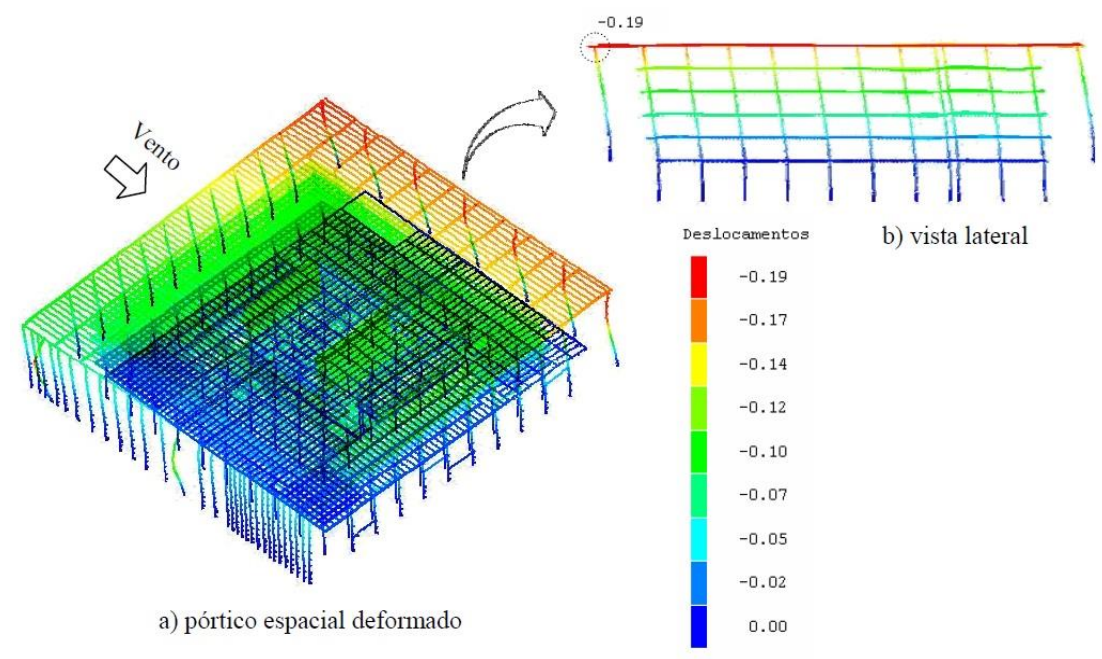

Figura 18 - Deslocamentos horizontais devidos ação do vento de incidência de $90^{\circ}$ Moreira (2007)

O autor utilizou a metodologia GDE/UnB proposta por Boldo (2002) para quantificar o grau de deterioração da estrutura, onde foi realizada uma vistoria no edifício com o intuito de avaliar o estado atual da estrutura e identificar as patologias presentes no monumento. Dividindo a estrutura em dois grupos: Grupo A - garagem, fachadas, jardim interno e cobertura, e Grupo B - todos os ambientes secos: salas, corredores, biblioteca, etc.

A Figura 19 mostra o gráfico com os resultados do grau de deterioração das famílias de elementos do grupo A (estrutura externa), onde se constatou um estado crítico ( $\mathrm{Gdf}>60$ ) de deterioração na maioria dos elementos observados. $O$ autor explica que a grande diferença entre o grau de deterioração da família de vigas e das famílias de lajes e pilares se deu pelo fato de que em muitas vigas foram visualizados vários danos com fator de intensidade elevado, gerando alto grau de deterioração no elemento. Observa-se também que não foram identificados patologias ou danos nos reservatórios superiores.

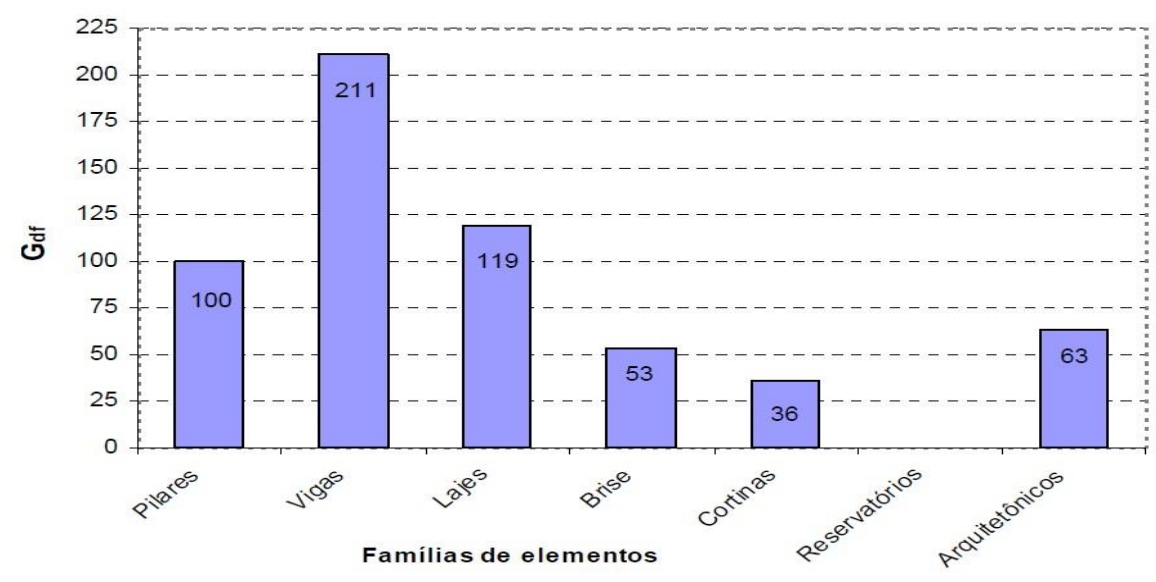

Figura 19 - Grau de deterioração das famílias de elementos do Palácio da Justiça Moreira (2007) 
A Tabela 9, mostra o grau de deterioração global da estrutura do Palácio da Justiça, referente ao grupo A, ou seja, a parte externa do edifício, com $\mathrm{Gd}=101$, a estrutura é classificada como nível crítico de deterioração $(\mathrm{Gd}>60)$ e sugere que sejam planejadas intervenções imediatas para restabelecer a segurança, a estética e funcionalidade do monumento.

Esse alto nível de deterioração deu-se pela existência de alguns pilares que apresentavam corrosão acentuada e perda de seção na armadura longitudinal, além das vigas dos pergolados do jardim as quais foram observadas armaduras expostas, em razão dos desplacamento do concreto superficial, decorrente da corrosão instalada e aumento de seção das armaduras com início da perda da seção da armadura principal e em alguns trechos a ruptura dos estribos. As fachadas também apresentavam muitas manchas escuras superficiais, corrosão das armaduras, fissuras estabilizadas e eflorescência, além do cobrimento deficiente nos elementos de forma generalizada.

Tabela 9 - O grau de deterioração global da estrutura do Palácio da Justiça (Gd) - Moreira (2007)

\begin{tabular}{|c|c|c|c|c|}
\hline Família de elementos & $\mathbf{G}_{\mathrm{df}}$ & $\mathbf{F}_{\mathbf{r}}$ & $F_{r} \times G_{d f}$ & Gd \\
\hline Elem. Arquitetônicos & 63 & 1,0 & 63 & \multirow{8}{*}{101} \\
\hline Reservatórios superiores & 0 & 2,0 & 0 & \\
\hline Cortinas & 36 & 3,0 & 108 & \\
\hline Brise & 53 & 4,0 & 212 & \\
\hline Lajes & 119 & 4,0 & 476 & \\
\hline Vigas & 211 & 5,0 & 1055 & \\
\hline \multirow[t]{2}{*}{ Pilares } & 100 & 5,0 & 500 & \\
\hline & $\Sigma=$ & 24,0 & 2414 & \\
\hline
\end{tabular}

Durante o desenvolvimento do trabalho do Moreira (2007), o Palácio da Justiça passou por uma intervenção e teve a limpeza do concreto aparente das fachadas, com retirada de manchas escuras e a recuperação das vigas do pergolado do jardim interno, ambos apenas de cunho estético. Após as intervenções terem sido finalizadas, o autor adotou novos fatores de intensidade para a manifestação do dano e calculou novamente o grau de deterioração das famílias de elemento do edifício (Gdf), conforme a Figura 20. 


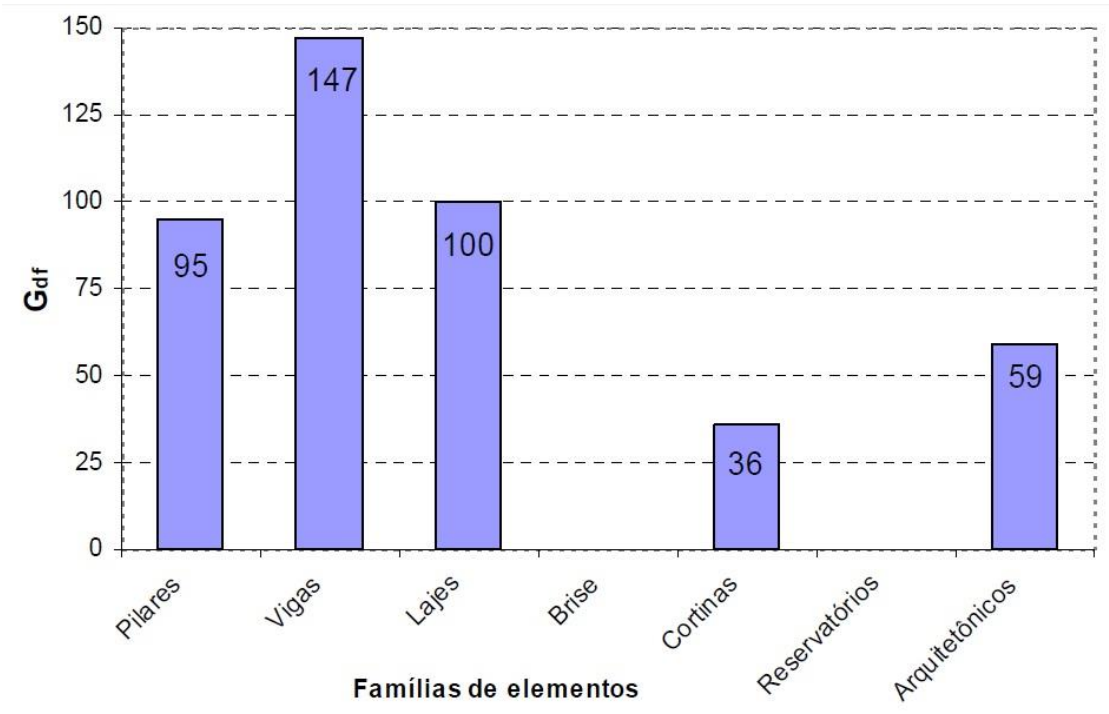

Figura 20 - O grau de deterioração das famílias de elemento do edifício (Gdf) após as intervenções - Moreira (2007)

A partir da Figura 20 acima, pode-se observar que a retirada de manchas nas lâminas dos brises das fachadas anulou o grau de deterioração dessa família e houve uma redução do grau de deterioração das famílias das vigas, com a recuperação das vigas do jardim. No entanto, muitos elementos ainda apresentam cobrimento deficiente e necessitam ainda de intervenções para restabelecer a estética, segurança e funcionalidade.

Com os novos valores, pode-se calcular também o novo grau de deterioração global da estrutura do Palácio da Justiça e que mesmo depois de ter passado por intervenções de cunho estético, continuava a apresentar um nível elevado de deterioração ( $\mathrm{Gd}>60)$, necessitando de um reparo imediato e emergencial, conforme mostra a Tabela 10.

Tabela 10 - O grau de deterioração global da estrutura do Palácio de Justiça (Gd) após as intervenções - Moreira (2007)

\begin{tabular}{|c|c|c|c|c|}
\hline Família de elementos & Gdf & Fr & Fr x Gdf & Gd \\
\hline Elem. Arquitetônicos & 59 & 1,0 & 59 & \multirow{8}{*}{74} \\
\hline Reservatórios superiores & 0 & 2,0 & 0 & \\
\hline Cortinas & 36 & 3,0 & 108 & \\
\hline Brise & 0 & 4,0 & 0 & \\
\hline Lajes & 100 & 4,0 & 400 & \\
\hline Vigas & 147 & 5,0 & 735 & \\
\hline \multirow[t]{2}{*}{ Pilares } & 95 & 5,0 & 475 & \\
\hline & $\Sigma=$ & 24,0 & 1777 & \\
\hline
\end{tabular}

Por fim, Moreira (2007) adota propostas de manutenção corretiva: nas vigas dos pergolados, propõe melhorar o cobrimento dos pilares das fachadas, lajes avarandadas, 
brises e outros elementos com o cobrimento deficiente e medidas de proteção para evitar a ocorrência de nova deterioração. Sugere também manutenção preventiva de acordo com a FIP (1988) propondo inspeções rotineiras realizadas em intervalos de no máximo 6 anos, com o uso de planilhas especificadas de cada elemento com responsável técnico da divisão de engenharia do ministério de justiça, composto por dois engenheiros, uma arquiteta e um técnico em edificações e inspeções extensivas também a cada 6 anos, intercaladas com a inspeção rotineira objetivando uma investigação mais detalhada feito por profissionais qualificados.

\subsubsection{Souza (2009)}

Souza (2009) estudou a história, a concepção, a execução do Teatro Nacional Claúdio Santoro e avaliou as condições da estrutura através da utilização de programas computacionais SAP2000 10.0.7, analisando os efeitos de variação de temperatura, além de quantificar o grau de deterioração das estruturas de concreto pela metodologia GDE/UnB e adotar propostas de manutenção para a extensão da vida útil do monumento histórico.

O Teatro Nacional Claudio Santoro está localizado no setor norte, no eixo monumental, situado ao lado da estação rodoviária de Brasília, recebeu esse nome em homenagem ao criador da orquestra sinfônica do teatro em 1989. É uma edificação semi-enterrada, com projeto arquitetônico de Oscar Niemeyer e cálculo estrutural do engenheiro Bruno Contarini. Possui três salas de espetáculos: a sala Villa-Lobos, Martins Pena e o espaço cultural Darcy Gonçalves. O projeto se destaca por sua forma, pela estrutura simples e coesa, pelos painéis em alto relevo, que compõem as fachadas norte e sul do artista plástico Athos Bulcão, pelos painéis de vidros escuros sustentados por vigas que formam as fachadas leste e oeste. A obra é equivalente a um edifício de aproximadamente 15 pavimentos, conforme a Figura 21.

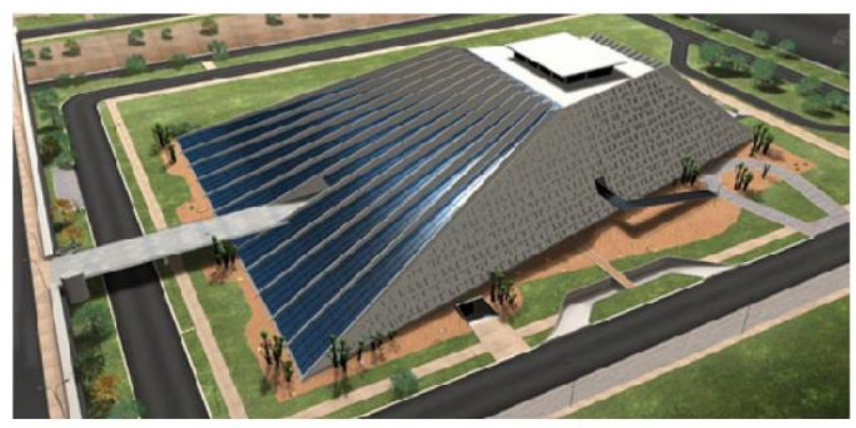

Figura 21 - Maquete Eletrônica do Teatro Nacional Claudio Santoro (ITS/Brasília) Souza (2009) 
A estrutura do teatro constitui-se de quatro pilares principais que recebem as cargas de todo o vigamento que é feito com concreto protendido. Essas vigas pré-moldadas, localizadas na fachada, possuem $50 \mathrm{~cm}$ de largura, e chegam até 72,0 $\mathrm{m}$ de comprimento.

Souza (2009) modelou a estrutura do Teatro no programa SAP2000 (Figura 22), adotando apoios de primeiro gênero nos pilares principais e apoios de segundo gênero dos pilares intermediários, e verificou as seções das vigas inclinadas e dos pilares principais, avaliando as influências que as elevadas variações de temperatura exercem sobre a estrutura.

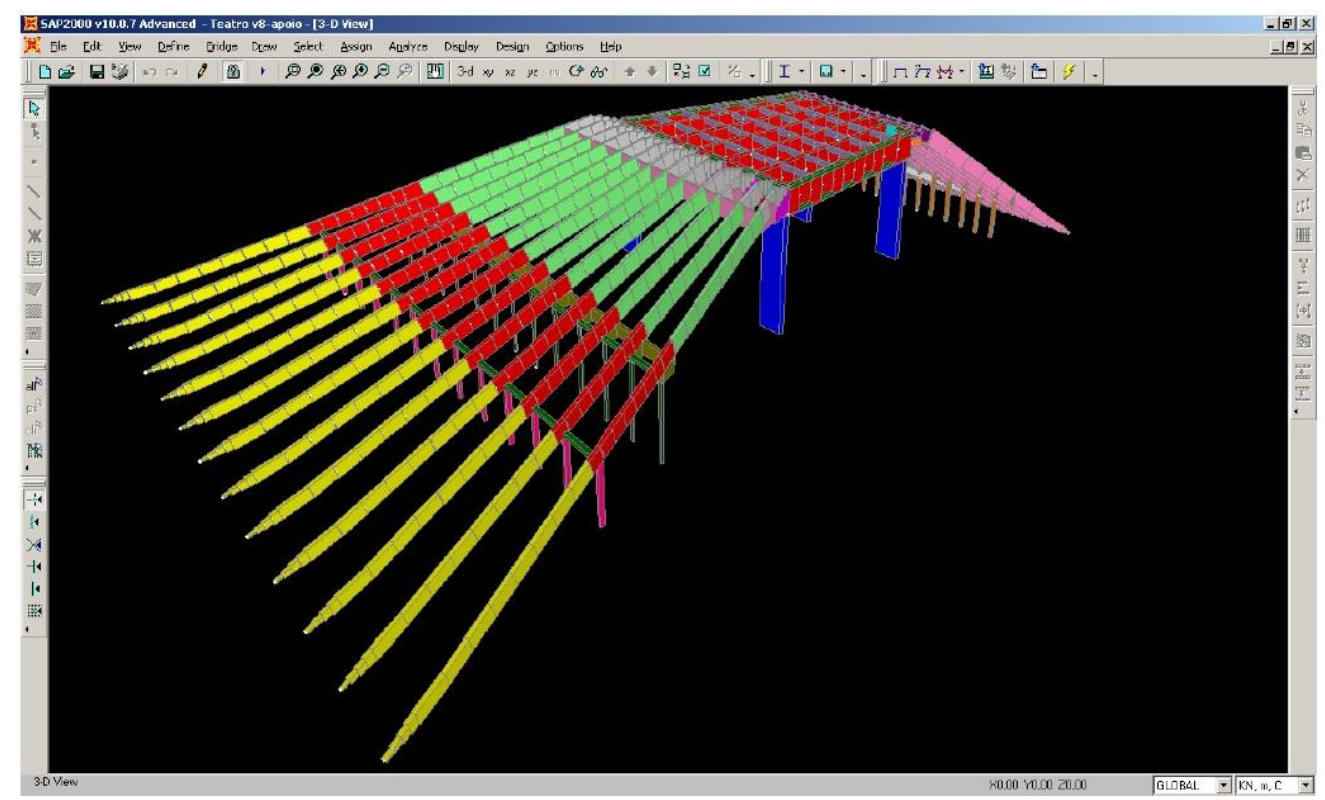

Figura 22 - Vista geral do modelo da estrutura principal do Teatro Nacional no SAP2000 Souza (2009)

O autor aplicou as devidas ações na estrutura, fez as combinações dessas cargas e obteve os resultados para duas situações: a primeira para a condição de apoio e a segunda, para condição de engaste, ambos sendo observando para a variação de temperatura $\left(\mathrm{T}=+/-15^{\circ} \mathrm{C}\right.$ e $\mathrm{T}=+/-25^{\circ} \mathrm{C}$ ). Obteve-se os deslocamentos lineares máximos (eixo x) para a condição de apoio de $1,27 \mathrm{~cm}$ para uma variação de $\mathrm{T}=+/-15^{\circ} \mathrm{C}$ e $2,33 \mathrm{~cm}$ para $\mathrm{T}=+/-25^{\circ} \mathrm{C}$. Já para a condição de engaste os deslocamentos lineares máximos (eixo x) foram de 1,00 cm para uma variação de $\mathrm{T}=+/-15^{\circ} \mathrm{C}$ e $1,90 \mathrm{~cm}$ para $\mathrm{T}=+/-25^{\circ} \mathrm{C}$. Além disso, encontrou valores de reações de apoio e esforços axiais nos pilares para ambos os casos.

Souza (2009) analisou também as flechas máximas nas vigas com vãos de 27,5 m (Sala Villa-Lobos), observando para a condição de apoio, flechas de 4,50 cm para uma variação de $\mathrm{T}=+/-15^{\circ} \mathrm{C}$ e $8,00 \mathrm{~cm}$ para $\mathrm{T}=+/-25^{\circ} \mathrm{C}$ e para condição de engaste, flechas de $4,00 \mathrm{~cm}$ para uma variação de $\mathrm{T}=+/-15^{\circ} \mathrm{C}$ e $7,60 \mathrm{~cm}$ para $\mathrm{T}=+/-25^{\circ} \mathrm{C}$. De acordo com a norma ABNT NBR 6118:2003 a flecha máxima admissível é de L/250 ou 11,0 cm, mostrando o 
bom comportamento estrutural e a boa qualidade do projeto feito naquela época quanto a variação da temperatura e posicionamento correto das juntas de dilatação.

O autor utilizou a metodologia GDE/UnB adaptada por Fonseca (2007) para quantificar o grau de deterioração da estrutura do Teatro Nacional, onde foi realizada uma vistoria no edifício com o intuito de avaliar o estado atual da estrutura e identificar as patologias presentes no monumento. Dividindo a estrutura em três grupos: Grupo A - Fachadas, coberturas, vigas de concreto aparente; Grupo B - Muros de arrimo e Grupo C - todos os ambientes internos secos: salas, corredores, pilares principais, etc.

A Figura 23 mostra o resultado do grau de deterioração das famílias da estrutura principal do Teatro Cláudio Santoro (lajes, pilares, muro de arrimo, placas de concreto pré-moldado de fechamento). $\mathrm{O}$ autor observou que o valor encontrado para as famílias do muro de arrimo (Grupo B), se deu devido aos valores atribuídos aos fatores de intensidade (Fi), sendo um pouco elevado para os danos encontrados na inspeção, apresentando um grau de deterioração nível médio $(15<\mathrm{Gdf}<50)$, indicando planejar atividades de manutenção de médio prazo (2 anos), para recuperar sua segurança, sua funcionalidade e estética.

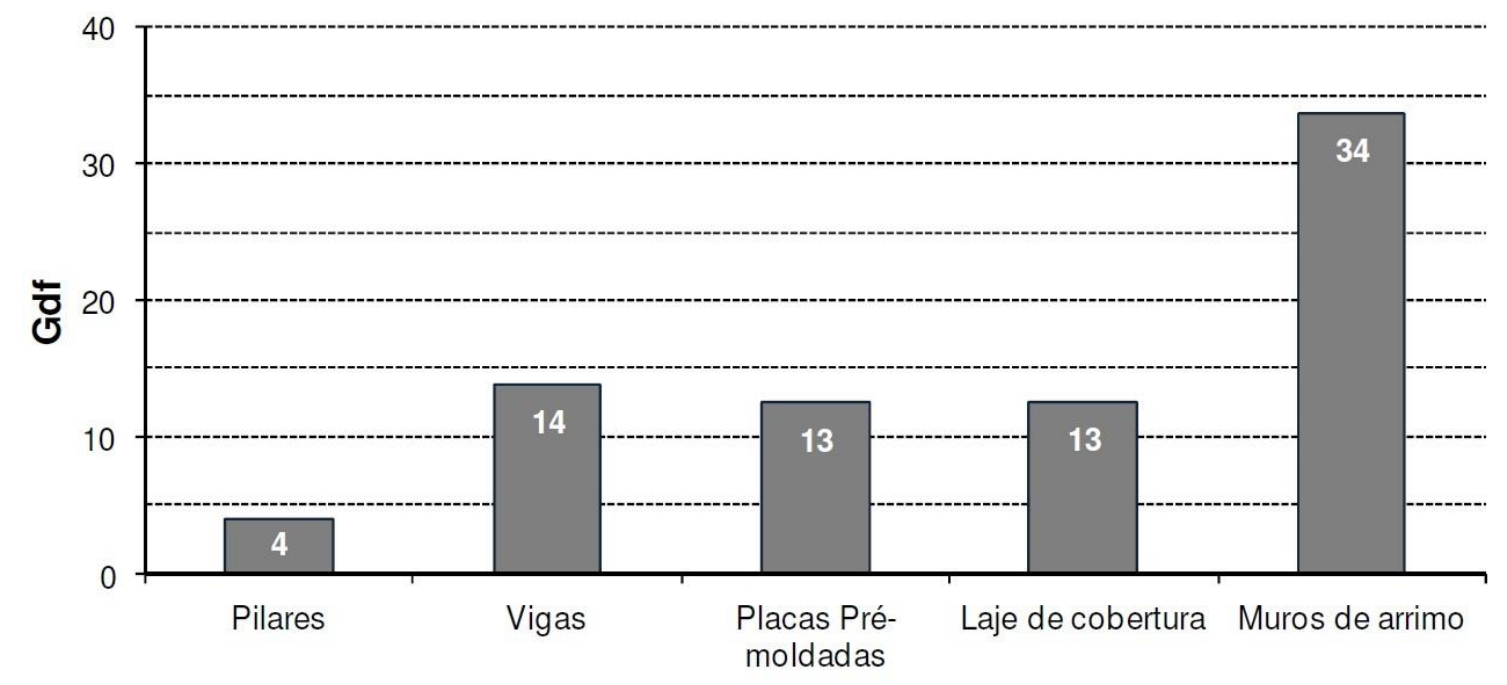

Família dos elementos

Figura 23 - grau de deterioração das famílias da estrutura principal do Teatro Cláudio Santoro - Souza (2009)

Conforme a Tabela 11, o grau de deterioração global da estrutura do Grupo A (internos secos) foi de $\mathrm{Gd}=13$ e para as famílias do Grupo C (ambientes externos) foi de $\mathrm{Gd}=4$, em ambos os casos apresenta um nível baixo de deterioração $(\mathrm{Gd}<15)$ sugerindo um estado aceitável e que seja planejado um programa de manutenção preventiva, para prolongar a 
vida útil do monumento. $\mathrm{O}$ autor propõe criar uma equipe técnica operacional do teatro, formada por dois engenheiros, um arquiteto e um técnico em edificações para realizar essas manutenções e realizar novas inspeções de acordo com o FIP (1988).

Tabela 11 - Grau de deterioração global da estrutura do grupo A (internos secos) e das famílias do grupo C (ambientes externos) - Souza (2009)

\begin{tabular}{|l|c|c|c|}
\hline Familia de elementos & $\mathrm{G}_{\mathrm{df}}$ & $\mathrm{F}_{\mathrm{r}}$ & $\mathrm{F}_{\mathrm{r}} \times \mathrm{G}_{\mathrm{df}}$ \\
\hline Obs.: Ambiente externo & 14 & 5 & 69 \\
\hline Vigas & 13 & 3 & 38 \\
\hline Placas Pré-moldadas & 13 & 4 & 50 \\
\hline Laje de cobertura & \multicolumn{4}{|c|}{} \\
\hline \multicolumn{4}{|c|}{} \\
\hline GRAU DE DETERIORAÇAO DA ESTRUTURA, $\mathrm{G}_{\mathrm{d}}:$ & $\mathbf{1 3}$ \\
\hline $\begin{array}{l}\text { 0< Gd < 15: Nível de Deterioração BAIXO } \\
\text { Estado aceitável - Manutenção Preventiva }\end{array}$
\end{tabular}

\begin{tabular}{|l|c|c|c|}
\hline Familia de elementos & $\mathrm{G}_{\mathrm{df}}$ & $\mathrm{F}_{\mathrm{r}}$ & $\mathrm{F}_{\mathrm{r}} \times \mathrm{G}_{\mathrm{df}}$ \\
\hline Obs.: Ambiente interno seco & 4 & 5 & 20 \\
\hline Pilares Principais & 4 \\
\hline \multicolumn{4}{|l|}{} \\
\hline GRAU DE DETERIORAÇÃO DA ESTRUTURA, $\mathrm{G}_{\mathrm{d}}:$ & 4 \\
\hline \multicolumn{4}{|l|}{} \\
\hline $\begin{array}{l}\text { 0< Gd < 15: Nível de Deterioração BAIXO } \\
\text { Estado aceitável - Manutenção Preventiva }\end{array}$ \\
\hline
\end{tabular}

\subsubsection{Bessa et al. (2013)}

Bessa et al. (2013) fez a análise global de estabilidade elástica da Torre de TV Digital de Brasília considerando os efeitos de $2^{\mathrm{a}}$. Ordem. Apresenta-se na análise os resultados obtidos com o SAP2000 e são comparados com as normas de Projeto de Estruturas de Concreto ABNT NBR 6118:2003 e Projeto de Estruturas de Aço ABNT NBR 8800:2003.

Os autores modelaram a Torre no programa computacional SAP2000, utilizando uma discretização em elementos finitos com um total de 9646 elementos de placas; 66504 elementos de casca (shell) e 1213 elementos de barras (frame), incluindo a torre de concreto e a torre metálica instalada no topo da torre, conforme a Figura 24. 


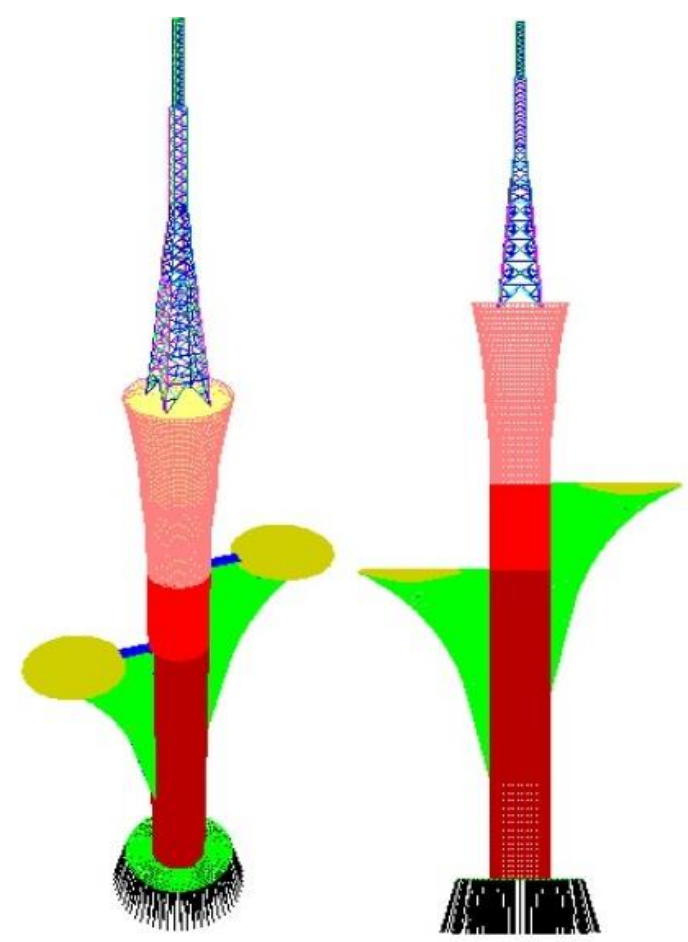

Figura 24 - Tipologia da estrutura analisada no SAP2000 - Bessa et al. (2013)

Bessa et al. (2013) adotaram os carregamentos na Torre de acordo com a especificação do projeto original, sendo cargas permanentes (peso próprio, revestimento e divisórias); sobrecargas (galeria bar e exposição) e ação do vento (ABNT NBR 6123:1988), onde a partir das combinações de cargas mais desfavoráveis o autor realizou uma análise elástica linear para verificação dos esforços no elemento e uma análise modal para verificação da frequência natural de vibração. A análise foi dividida em duas etapas: análise das fundações e análise da estrutura de concreto armado.

A fundação da torre é formada por um bloco de concreto de $25 \mathrm{~m}$ de diâmetro com altura de 4,5 m, apoiado sobre 246 estacas do tipo raiz cada uma com $12 \mathrm{~m}$ de profundidade e 41 cm de diâmetro, conforme Figura 25.

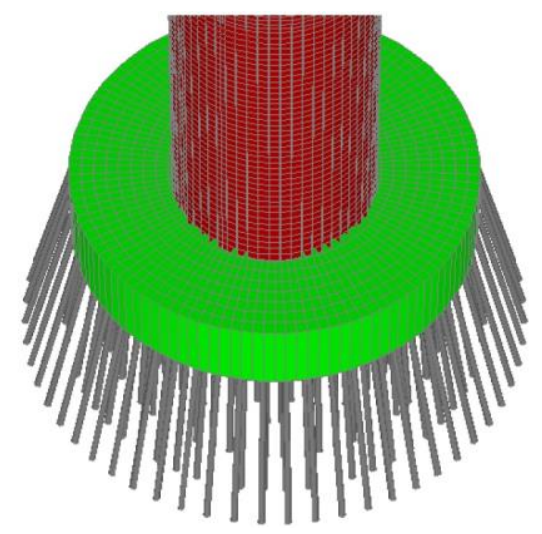

Figura 25 - Parâmetros e esquema das estacas, modelo no SAP2000 - Bessa et al. (2013) 
A capacidade de carga da estaca foi verificada pelo método David-Cabral no qual é considerada a pressão da injeção a ar comprimido (p) aplicada no topo da estaca e o atrito lateral para cada trecho do fuste, e a resistência de ponta são calculados por meio de coeficientes empíricos. Obteve-se pelo método David-Cabral a capacidade de carga das estacas, ou seja, a carga admissível para a profundidade de $12 \mathrm{~m}$ para cada estaca é de 170,2 tf e o valor máximo de esforço normal atuante nessa estaca obtido na análise SAP2000 foi de 99 tf. Portanto, a carga atuante é menor que a carga admissível, demonstrando segurança quanto à estabilidade global do edifício. $\mathrm{E}$ para o dimensionamento estrutural das estacas submetidas à flexão composta, utilizou o método professor Lauro Modesto, verificando as seções circulares com os seguintes parâmetros de entrada: fck, fyk, módulo de elasticidade do material e os números de barras de aço.

O autor também encontrou a área de aço do fuste, dos braços, as nervuras e outros elementos estruturais da torre e todas essas armaduras encontradas foram confrontadas com o aço especificado no projeto e verificou que atende as necessidades quanto a norma ABNT NBR 6118:2003.

$\mathrm{Na}$ análise linear elástico, foi realizado uma verificação dos deslocamentos horizontais máximos atuantes na torre de concreto, encontrando no programa SAP2000 um deslocamento de $7,7 \mathrm{~cm}$ ou $(\mathrm{H} / 1623)$ no topo da torre e uma rotação máxima igual a 0,00072 rad. No entanto, de acordo com a norma ABNT NBR 6118:2003 (Item 13.3) o deslocamento horizontal máximo é de $\mathrm{H} / 500$ e a rotação máxima de $10 \mathrm{~mm}$ ou $\Theta=0,0017$ rad, atendendo assim, as prescrições previstas na norma.

Analisou também a Torre como haste engastada na base e submetida a ação de cargas devidas ao vento, e encontrou um deslocamento horizontal de $8,35 \mathrm{~cm}$, diferença de $7,7 \%$ quanto ao deslocamento encontrado no modelo elemento finito que foi de $7,7 \mathrm{~cm}$.

Tendo em vista os dados disponíveis oriundos dos ensaios de túnel de vento que será abordado no item 3.2, optou-se por adotar os deslocamentos no topo da torre em concreto proporcionais às forças obtidas no ensaio de túnel de vento. O ponto de partida é a correção dos momentos na base da Torre para a velocidade básica do vento de $35 \mathrm{~m} / \mathrm{s}$. Vale ressaltar que serão adotados os valores de momento para a situação com antenas parabólicas, tendo em vista ser esta a situação mais desfavorável. Encontrando-se um fator de correção de $0,53, \log$ o o deslocamento no topo $(\delta \mathrm{t})$ da torre em concreto corrigido é $8,35 \times 0,53$, ou seja, $\delta$ t igual a $4,42 \mathrm{~cm}$. 
A frequência natural de vibração $(\mathrm{Hz})$ pode ser obtida pela expressão (Comitê EuroInternational du Beton - CEB, Bulletin d'information no 209, Vibration Problems in Structures, Pratical Guidelines) f $=46 / \mathrm{H}$, onde H é a altura da torre. Assim, para o caso presente tem-se $\mathrm{f}=46 / 125=0,37 \mathrm{~Hz}$.

Vale ressaltar que a frequência natural de vibração, obtida pela análise de elementos finitos, a qual está associada ao modo de vibração compatível com a atuação da carga de vento é igual a $0,44 \mathrm{~Hz}$, ou seja, diferença de $16 \%$ entre os valores recomendados pelo CEB e o valor obtido pela análise de elementos finitos. De acordo com CEB, a torre está no limite de vibração perceptível e pode ser utilizada sem causar desconforto aos usuários.

\subsubsection{Conclusões a cerca das pesquisas realizadas}

Todos os trabalhos visam o objetivo maior de avaliar as condições físicas atuais dos monumentos históricos de Oscar Niemeyer em Brasília, contribuindo principalmente com a adoção de propostas de manutenção para garantir a extensão da vida útil desses bens tombados.

Os resultados da avaliação feita pela metodologia GDE/UnB para quantificação dos danos na estrutura mostra-se coerente e reflete o estado de deterioração encontrado nos elementos inspecionados, alertando para a necessidade de intervenções, indicando prazo e medidas a serem tomadas.

Observou-se também que o roteiro para avaliação da condição física do edifício, depende muito da iniciativa do aluno, do material encontrado, da capacidade para trabalhar com modelos computacionais, etc. O importante é levantar o máximo de informações possíveis para ter o bom conhecimento do monumento: análise histórica (documentos, projetos, etc.); análise qualitativa (levantamento, investigação, etc.); e análise quantitativa (ensaios, modelos matemáticos, etc.).

Essas pesquisas, de forma geral, consistem na associação da análise estrutural (software de análise) do edifício e a vistoria à obra com o auxílio do roteiro de inspeção (metodologia GDE/UnB). Exceto, Bessa et al. (2013), pois o objetivo do artigo é analisar a estabilidade global da Torre de TV Digital de Brasília.

A maioria desses trabalhos foram desenvolvidos no PECC-UnB na linha de pesquisa: "Patologia, Manutenção, Análise e Recuperação das Estruturas", e teve como orientadores os professores João Carlos Teatini e Antônio Alberto Nepomuceno. 


\subsection{PRINCÍPIOS GERAIS DA AVALIAÇÃO DE ESTRUTURAS DE CONCRETO}

A importância da conscientização da manutenção e conservação do patrimônio brasileiro, ainda é meio tardia no nosso país. Sendo que, a maioria dos monumentos históricos, que geralmente são obras públicas, acabam se deteriorando por falta de cuidados e restauros necessários.

Com intuito de preservar e garantir uma vida longa para os monumentos históricos, em 2001, o Conselho Internacional de Monumentos e Sítios - ICOMOS, no Comitê Internacional para a Análise e Restauro de Estruturas do Patrimônio Arquitetônico, propôs um documento com "recomendações para a análise, conservação e restauro estrutural do patrimônio arquitetônico", no qual se estabelece metodologias de análise racionais e métodos de intervenção apropriados ao contexto cultural.

Portanto, a realização da avaliação estrutural deverá ser feita conforme as recomendações indicadas pelo ICOMOS (2001), associados a outras publicações, artigos, normas e livros que tratam do assunto. A seguir é descrita a metodologia adotada para a investigação do edifício, servindo de guia prático para a realização da inspeção e avaliação da estrutura do monumento arquitetônico em estudo.

\subsubsection{Aspectos gerais}

De acordo com o ICOMOS (2001), a conservação do patrimônio arquitetônico, geralmente requer uma abordagem multidisciplinar envolvendo uma variedade de profissionais e organizações. Qualquer estudo ou planejamento para a conservação estrutural demanda tanto dados qualitativos, baseados na observação direta da deterioração do material e de danos estruturais, pesquisa histórica, etc., quanto dados quantitativos baseados em testes específicos e modelos matemáticos usados na engenharia moderna. Por esse motivo, essas combinações de abordagens tornam-se muito difíceis estabelecer regras e códigos.

Esses aspectos subjetivos envolvidos no estudo e na avaliação da segurança de um edifício, as incertezas nos dados utilizados e as dificuldades em fazer uma avaliação precisa dos fenômenos podem levar a conclusões de confiabilidade incerta. Portanto, é importante apresentar claramente todos os aspectos, demonstrando o cuidado tomado no desenvolvimento do estudo e a confiabilidade dos resultados. Além disso, o mais importante é a aplicação da combinação do conhecimento cientifico e cultural e de 
experiência que é indispensável para a correta abordagem do estudo e de todo o patrimônio arquitetônico.

Do mesmo modo, é necessário conhecer a correta forma de fazer inspeção, como realmente investigar e avaliar a estrutura do edifício.

\subsubsection{Investigação}

De acordo com o ICOMOS:

A investigação das estruturas que visa avaliar a segurança e a durabilidade do edifício é um processo que depende e requer de uma abordagem interdisciplinar. Para isso, é de extrema importância ter uma equipe com uma série de conhecimentos apropriados e com uma certa experiência para a correta realização dessa inspeção, e, portanto, dispor de recomendações e medidas preventivas necessárias, pois, caso contrário, essa investigação pode chegar a resultados não confiáveis. (ICOMOS, 2001).

Segundo esse Instituto, para se ter um conhecimento da estrutura é necessário obter informações sobre sua concepção, as técnicas construtivas utilizadas na obra, os processos e os fenômenos que ocorreram e, finalmente seu estado presente. Este conhecimento pode geralmente ser alcançado pelas seguintes etapas:

- Pesquisa histórica cobrindo a vida inteira da estrutura;

- Definição, descrição e compreensão do seu significado histórico e cultural, e dos materiais de construções e técnicas originais;

- Descrição da estrutura no seu estado atual incluindo as identificações dos danos, da deterioração e dos possíveis fenômenos progressivos, usando testes apropriados;

- Identificação das forças envolvidas, do comportamento estrutural e dos tipos de materiais;

- Um relato de todas as intervenções anteriores.

A Associação Brasileira de Engenharia e Consultoria Estrutural - ABECE (2005) propõe um "check list para vistorias de edificações em concreto armado", onde mostra através de um fluxograma na Figura 26 as etapas de inspeção ou investigação da estrutura. 


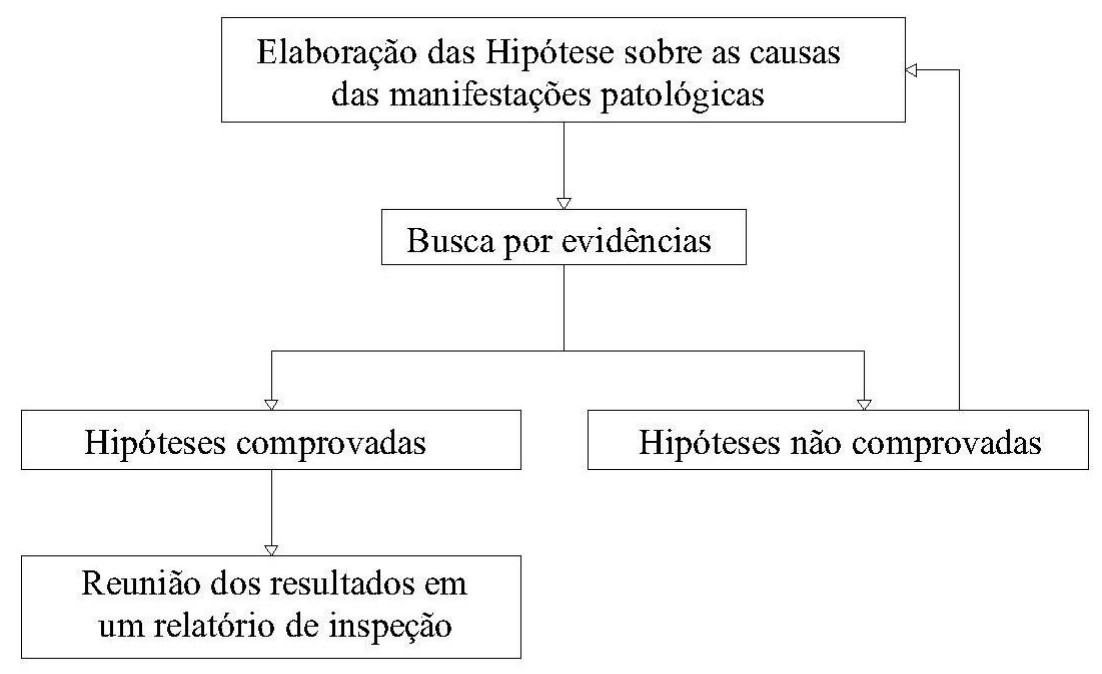

Figura 26 - Etapas de inspeções das estruturas de concreto - ABECE (2005)

Após a realização do estudo e dos seguintes passos feitos em diversos níveis de aprofundamento é importante propor um plano de atividades proporcional aos problemas encontrados na estrutura e, se necessário, implementá-lo em diferentes estágios.

\subsubsection{Pesquisa histórica}

Para o ICOMOS (2001), “o ponto de partida para a realização de uma pesquisa histórica é estudar e conhecer o lugar onde está inserido o monumento, os fatores que levaram ao planejamento dessa construção, os profissionais e firmas envolvidas, a data, as etapas de construção, a inauguração e as suas intervenções realizadas".

O objetivo da pesquisa histórica é de compreender a concepção e o significado do edifício, as técnicas e as perícias usadas na sua construção, modificações tanto na estrutura como no ambiente ao seu redor, e finalmente, conhecer os eventos que possam ter causado danos.

Dar uma atenção especial para quaisquer danos, colapsos, reconstruções, adições, modificações, trabalhos de restauração, modificações estruturais e qualquer mudança no uso da estrutura que tenha levado a sua condição atual.

Segundo Ricardo (2002), quando ocorre um desvio da utilização para a qual a estrutura de concreto armado foi projetada e executada, ocorre duas situações, a saber:

a) a estrutura, devido à atuação de sobrecarga não prevista e incompatível com o projeto, precisa de intervenção para garantir a segurança;

b) a estrutura não atende os requisitos das mudanças de utilização e precisa ser adequada à nova necessidade por exigência da funcionalidade. 
Essas alterações de uso e das outras informações contidas no histórico da edificação, demonstram como a estrutura tem interagido com os eventos naturais, como sobrecargas imprevistas, variações térmicas, ação do vento, etc., ou talvez alterando o comportamento original da estrutura e causando rachaduras, fissuras, esmagamento, deterioração, colapso, etc.

Deste modo, é necessário saber toda a história do monumento e estudar o que realmente ocorreu no passado, para melhor estimar o grau de segurança do estado atual da estrutura. Sendo de extrema importância a observância desses fatores do ponto de vista estrutural se preocupando sempre com a segurança dos usuários.

\subsubsection{Inspeção da estrutura}

De acordo com o ICOMOS (2001), a inspeção estrutural é a observação direta da estrutura, e é a fase essencial do estudo, geralmente feito por uma equipe qualificada a fim de fornecer uma compreensão inicial da estrutura dando uma direção apropriada às investigações subsequentes.

Entre os objetivos principais dessa observação estão:

I- Identificar deterioração e danos na estrutura;

II- Determinar se os fenômenos estão estabilizados ou não;

III- Decidir se há riscos imediatos e medidas urgentes a serem tomadas;

IV- Descobrir se o meio ambiente é danoso ao edifício.

De acordo com o Icomos:

O estudo de falhas estruturais começa pelo o mapeamento de danos visíveis e é um trabalho bastante delicado na qual a interpretação do que foi encontrado deve ser usado para direcionar o processo de levantamento. Durante este processo, o especialista já deve estar desenvolvendo uma ideia de possíveis esquemas estruturais de modo que aspectos críticos da estrutura possam ser examinados em maiores detalhes. (ICOMOS, 2001).

É importante descobrir como o meio ambiente pode estar danificando uma edificação, já que isto pode ser agravado pelo descuido durante o período original da construção (falta de drenagem, condensação, umidade ascendente devido à ação capilar, etc.,), pelo o uso de materiais inadequados e pelas faltas de manutenção subsequentes. 
Os levantamentos geométricos, fotográficos, ou desenhos devem mapear diferentes tipos de materiais, notando sua deterioração, suas irregularidades e danos estruturais, prestando atenção especial aos padrões de fissuras e as evidências de esmagamento. A observação de áreas onde estão os danos em particular "zonas de esmagamento" (alta compressão) e "zona de fissuração ou desplacamento" (alta tração) uma investigação das condições do solo pode indicar as causas de tais danos.

\subsubsection{Ensaios e procedimentos}

\section{Segundo o ICOMOS:}

Tanto à pesquisa de campo como os testes em laboratórios devem haver uma programação de ensaios baseada em uma visão clara dos fenômenos cuja compreensão possa ser relevante. Testes geralmente tem o objetivo de identificar as características mecânicas (resistências, deformabilidade, etc.), físicas (porosidade, etc.) e químicas (composição, etc.) dos materiais, as tensões e deformações da estrutura, a presença de descontinuidades e ou trincas no interior da armadura, etc. Como regra, a programação de ensaios deve ser dividida em estágios, começando com a aquisição de dados básicos e continuando com exames e testes mais extensos baseado em uma avaliação de dados iniciais. (ICOMOS, 2001).

Associação Brasileira de Engenharia e Consultoria Estrutural - ABECE (2005) divide os ensaios em dois grupos, os ensaios que visam o comportamento estrutural e os ensaios com vistas à durabilidade. Como mostra a seguir:

Estrutural: Determinação da bitola e posicionamento das armaduras; perda de seção da armadura por corrosão; dureza superficial do concreto; resistência a compressão e tração de testemunhos extraídos do concreto e de amostras de aço e provas de carga na estrutura.

Durabilidade: Medida da espessura da camada de concreto de cobrimento; taxa de corrosão do aço; profundidade de carbonatação do concreto; teor de ions cloreto na massa de concreto; índice de vazios, absorção de água e massa específica; umidade do ar e variações de temperatura.

É importante ressaltar que as propriedades do material, como resistência à compressão e o módulo de eslastidade do concreto, pode ser alterado com o tempo devido o mecanismo de envelhecimento da estrutura.

Portanto, os ensaios devem ser realizados por profissionais habilitados capazes de avaliar corretamente sua confiabilidade e as implicações dos resultados devem ser cuidadosamente 
avaliados. Afim de obter resultados mais precisos, se possível, usar diferentes métodos de ensaios e fazer uma comparação dos valores.

\subsubsection{Monitoramento}

Segundo o documendo publicado no ICOMOS (2001), a observação estrutural durante um período de tempo pode ser necessária não somente para adquirir informação útil quando existir suspeita de fenômeno progressivo, mas também durante os diferentes estágios de intervenção estrutural. Nestes casos, os efeitos são monitorados a cada estágio (abordagem de observação) e dados adquiridos serão usados como base para qualquer decisão futura.

\section{Conforme o ICOMOS:}

Os sistemas de monitoramento geralmente objetivam registrar modificações em deformações, fissuras, temperaturas, etc. Deve ser levado em consideração o custobenificio das realização desses monitoramento, no caso, da propagação de trincas, a maneira mais simples e mais barata para monitorar a aberturas de fissuras, é colocar um selo de gesso ou vidro (testemunho) sobre elas. Deste modo, se faz necessário saber se os dados são realmente relevantes para se realizar um procedimento de monitoramento de custo elevado. (ICOMOS, 2001).

\subsubsection{Desempenho Estrutural}

Segundo o ICOMOS (2001) "O comportamento de qualquer estrutura é influenciado por três fatores principais: a forma e as ligações da estrutura; os materiais de construção; as ações atuantes e as condições ambientais".

\subsubsection{O modelo estrutural}

O comportamento estrutural depende das características dos materiais usados, das dimensões da estrutura, das ligações entre diferentes elementos, das condições do solo, etc.

\section{Para o ICOMOS:}

O comportamento real de um edifício é geralmente tão complexo que somos obrigados identificá-los através de um "esquema estrutural" simplificado, isto é uma idealização do edifício que mostra de uma maneira mais ou menos precisa sua função em resistir às várias ações. O esquema estrutural mostra a maneira em que o edifício transforma ações em tensões e garante sua estabilidade. (ICOMOS, 2001).

Com os avanços tecnológicos nas teorias de análise experimental e das ferramentas computacionais, os esquemas estruturais simplificados não são mais necessários. Logo, um 
edifício pode ser representado por diferentes esquemas com diferentes complexidades e diferentes graus de aproximação à realidade.

Para que haja uma boa análise do desempenho estrutural, necessita de um modelo estrutural que deve se aproximar ao máximo possível da estrutura real, levando em consideração parâmetros como a heterogeneidade do material concreto armado (concreto mais aço), seu comportamento não linear, fluência, rigidez das ligações, tratamento adequado das ações, etc.

Segundo as recomendações publicadas no ICOMOS:

O esquema ou modelo estrutural original pode mudar devido a danos (fissuras, etc.), a reforços ou outras modificações do edifício. O esquema usado para os cálculos deve levar em conta alterações e deteriorações, tais como trincas, descontinuidades, esmagamentos, inclinações, etc., quando o seu efeito pode influenciar significativamente o comportamento estrutural. Estas alterações podem ser provocadas tanto por fenômenos naturais quanto por intervenções humanas. Ao último pode incluir: a redução da capacidade, portanto, devido à execução de aberturas, nichos, etc.; a criação de forças não equilibradas devido à eliminação de arcos, vigas, paredes, etc.; o aumento de peso como resultado do aumento de sobrecargas à estrutura; a redução da capacidade resistente do solo devido a escavações, galerias, edifícios, vizinhos, etc. (ICOMOS, 2001).

\subsubsection{Propriedades dos materiais}

Segundo o ICOMOS (2001) "as propriedades do material, em particular a resistência à compressão e módulo de elasticidade do concreto, que são parâmetros básicos para qualquer cálculo de avaliação estrutural, podem ser reduzidos por processos de deterioração por causa da ação química, física ou biológica”.

A velocidade do mecanismo de envelhecimento e deterioração do concreto depende das propriedades dos materiais (tais como a porosidade) e a maneira pela qual a estrutura é protegida (a projeção do telhado, etc.), bem como sua manutenção.

Embora a deterioração possa se manifestar na superfície, e assim ser imediatamente aparente de uma inspeção superficial (eflorescência, aumento de porosidade, etc.), há também processos de deterioração que somente podem ser detectados por meio de testes e ensaios sofisticados. 


\subsubsection{Ações a Considerar}

Conforme a norma ABNT NBR 6118:2014, na análise estrutural deve ser considerada a influência de todas as ações que possam reproduzir efeitos significativos para a segurança da estrutura em exame, levando em conta os possíveis estados limites últimos (perda de equilíbrio, ruptura e instabilidade por deformação) e os de serviços (danos localizados, deformações e vibrações excessivas).

Conforme o ICOMOS:

As ações são definidas como qualquer agente (força, deformações, etc.) que produz tensões e esforços na estrutura e qualquer fenômeno (químico, físico ou biológico) que afeta os materiais, geralmente reduzindo sua resistência. Na maioria das vezes, mais de uma ação ou talvez modificação inesperada das ações originais terá afetado a estrutura e estas ações devem claramente serem identificadas antes de decidir as medidas de reparo. (ICOMOS, 2001).

De acordo a norma ABNT NBR 8186:2003, as ações estão classificadas segundo sua variabilidade no tempo em três categorias:

a) Ações permanentes:

- Direta: os pesos próprios dos elementos de construção, incluindo-se o peso próprio da estrutura e o peso de todos os elementos construtivos permanentes, os pesos dos equipamentos fixos e os empuxos devidos ao peso próprio de terras não removíveis e de outras ações permanentes aplicadas sobre ela.

- Indireta: a protensão, imperfeições geométricas, os recalques de apoios e retração dos materiais.

b) Ações variáveis:

- Direta: carga acidental e ação do vento.

- Indireta: variações de temperatura e ações dinâmicas.

c) Ações excepcionais: São ações decorrentes de causas, como explosões, choques de veículos, incêndios, enchentes ou sísmicos excepcionais.

As ações permanentes (peso próprio, protensão, etc.) são aquelas que ocorrem com intensidade constante ou com poucas variações previstas durante a vida útil do edifício. Já as ações variáveis (ação do vento, variações térmicas, etc.) ocorrem sem continuidade ou com variações significativas durante a vida do monumento. 
Como foi visto, as ações permanentes e variáveis se dividem em dois grupos: ações diretas

- consistem em forças aplicadas diretamente à estrutura; e ações indiretas - são deformações impostas à estrutura. Estas ações só irão produzir esforços no caso de as deformações não estarem livres para se desenvolverem, elas podem atuar de maneira contínua ou cíclica.

No entanto, as cargas excepcionais são imprevisíveis quanto ao momento em que podem atuar sobre a estrutura, e possuem uma probabilidade muito baixa de ocorrência, mas que devem ser consideradas nos projetos de determinadas estruturas que requer uma maior atenção.

\subsubsection{Ações físicas, químicas e biológicas}

Estas ações são de natureza completamente diferente das previamente descritas. Elas podem produzir diferentes tipos de deterioração e, consequentemente, mudar as propriedades dos materiais e, portanto, a sua resistência.

Estas ações podem ser influenciadas e aceleradas pela presença de água (chuva, umidade, água do solo, ciclos de molhagem e secagem, crescimento orgânico, etc.), variações de temperatura (ação de congelamento, o fogo, a expansão e contração) e condições microclimáticas (poluição, deposição superficial, mudanças na velocidade do vento devido às estruturas vizinhas, etc.).

Segundo Fonseca (2007), tais fenômenos podem comprometer a estética, a durabilidade e segurança da obra, onde a combinação com outros fenômenos poderia ser: Física, a deterioração por desgaste superficial, ocasionado, por exemplo, pela abrasão proveniente da circulação de veículos e pessoas; Química, a degradação produzida no concreto devido a presença de líquidos contaminados; ou Biológica, o ataque sofrido pelo concreto em estruturas submetidas ao contato com matéria orgânica. Todas essas ações comprometem a durabilidade e a segurança do edifício.

Portanto, cabe ao especialista que está realizando a inspeção ou a observação direta da estrutura, identificar o mecanismo que está causando a deterioração e alterar as propriedades dos materiais quando puder. As identificações das patologias e suas causas encontradas na inspeção fazem parte do diagnóstico. 


\subsubsection{Diagnóstico}

O sucesso para ter uma boa avaliação da situação real do edifício, está na correta interpretação dos dados coletados, ou seja, o diagnóstico. É importante nessa etapa a participação do profissional habilitado, capaz de realizar a inspeção de forma precisa, detectando os danos e as causas da deterioração, para posteriormente, sugerir um programa de manutenção a partir da dedução do nível de deterioração da estrutura do edifício.

Segundo ICOMOS (2001), “o diagnóstico identifica as causas de danos e deterioração com base nos dados adquiridos, obedecendo três aspectos estabelecidos: Análise histórica (documentos, projetos, etc.); Análise qualitativa (levantamento, investigação, etc.); e Análise quantitativa (ensaios, modelos matemáticos, etc.) ”.

Devido as diversas variáveis envolvidas no diagnóstico, torna essa fase a mais difícil, uma vez que os dados disponíveis frequentemente se referem a efeitos, enquanto o que deve ser determinado é a causa ou causas concomitantes. Devido a isso, pode-se chegar a resultados sem tanta confiabilidade.

É por esse motivo que a intuição e a experiência são componentes essenciais no processo de diagnóstico. Nessa etapa final, um correto diagnóstico é indispensável para uma avaliação adequada da segurança e para decisões racionais sobre as medidas de tratamento a serem adotadas.

\subsubsection{Avaliação da segurança}

A avaliação da segurança é a etapa que tem o intuito de completar o diagnóstico. Onde em posse das causas de danos e deterioração, cabe realizar uma avaliação da segurança do edifício e determinar se os níveis de segurança são aceitáveis ao analisar a condição atual da estrutura e dos materiais.

A fase de avaliação da segurança é um passo essencial no processo de manutenção e restauração do edifício, pois é nessa etapa que é determinada a necessidade da tomada de medidas corretivas e suas extensões.

Assim como no diagnóstico, a avaliação estrutural também é uma tarefa difícil, já que também existem vários fatores que podem levar a interpretações incoerentes. Fatores, tais como, dificuldades em compreender apropriadamente a complexidade do edifício, as incertezas quanto às características dos materiais, o conhecimento deficiente sobre as alterações ou intervenções realizadas, etc. 
Então, quando o arquiteto ou engenheiro for realizar uma avaliação da segurança do edifício, deve estar ciente que uma abordagem quantitativa baseada em modelos matemáticos não podem ser o único procedimento a ser adotado, deve ser associado a ferramentas computacionais capaz de ajudar na avaliação estrutural e na confiabilidade dos resultados. Além disso, deve estar agregado a uma abordagem qualitativa, assim como o diagnóstico com a pesquisa histórica e a observação da estrutura e, se preciso, realizar uma abordagem de ensaios específicos em situações especiais.

Desse modo, todas essas abordagens fornecem informações para a avaliação da segurança do edifício, mas é a análise associada a todas essas informações obtidas que podem levar ao melhor julgamento, ou seja, melhor definição da situação física atual do edifício em estudo.

\subsection{METODOLOGIA GDE/UnB PARA QUANTIFICAÇÃO DO GRAU DE DETERIORAÇÃO DA ESTRUTURA}

A metodologia GDE/UnB surgiu devido o crescente número de edificações com estruturas de concreto armado, que apresentam deterioração precoce, com manifestações de danos de diversas origens. Onde a ausência quase absoluta de programa de manutenção preventiva das estruturas contribuíu para que isso ocorra com mais frequência.

Foi desenvolvida no PECC, a partir de Castro (1994), na dissertação de mestrado de Pósgraduação em Estruturas e Construção Civil, com o objetivo de classificação de danos e avaliação da deterioração das estruturas de concreto. Castro tomou como base a metodologia de Klein et al. (1991), onde adaptou a metodologia desenvolvida para quantificar obras de artes para as edificações usuais de concreto, pois a mesma detectou que a teoria resultava em dados insatisfatórios para esses tipos de edificações.

A metodologia foi desenvolvida e aplicada em diversos estudos de avaliação estrutural, se mostrando eficiente e sofrendo várias modificações por Lopes (1998), Boldo (2002) e Fonseca (2007). Houve várias dissertações que utilizaram a metodologia, como Euqueres (2011) que avaliou pontes de concreto armado e Verly (2015) que avaliou obras de artes especiais - OAEs juntamente com o DNIT, em rodoviárias localizadas na região metropolitana de Brasília.

O GDE / UnB é uma metodologia para classificação de danos e avaliação da deterioração de estruturas de concreto armado de edificações usuais, que estabelece critérios para a classificação de danos que permitem calcular o grau de deterioração dos elementos 
estruturais isolados e da estrutura como um todo, indicando as ações necessárias ao desenvolvimento da vida útil prevista (BOLDO, 2002).

Para a quantificação e avaliação da estrutura em estudo, tomaremos como base a última atualização da metodologia GDE/UnB, feita por Fonseca (2007), que propõe modificações no "roteiro de inspeção" adaptando conceituações de danos mais frequentes e a utilização de norma vigente. O fluxograma da Figura 27 mostra o procedimento a ser adotado para a realização das inspeções e definição do grau de deterioração, e principalmente a avaliação estrutural.

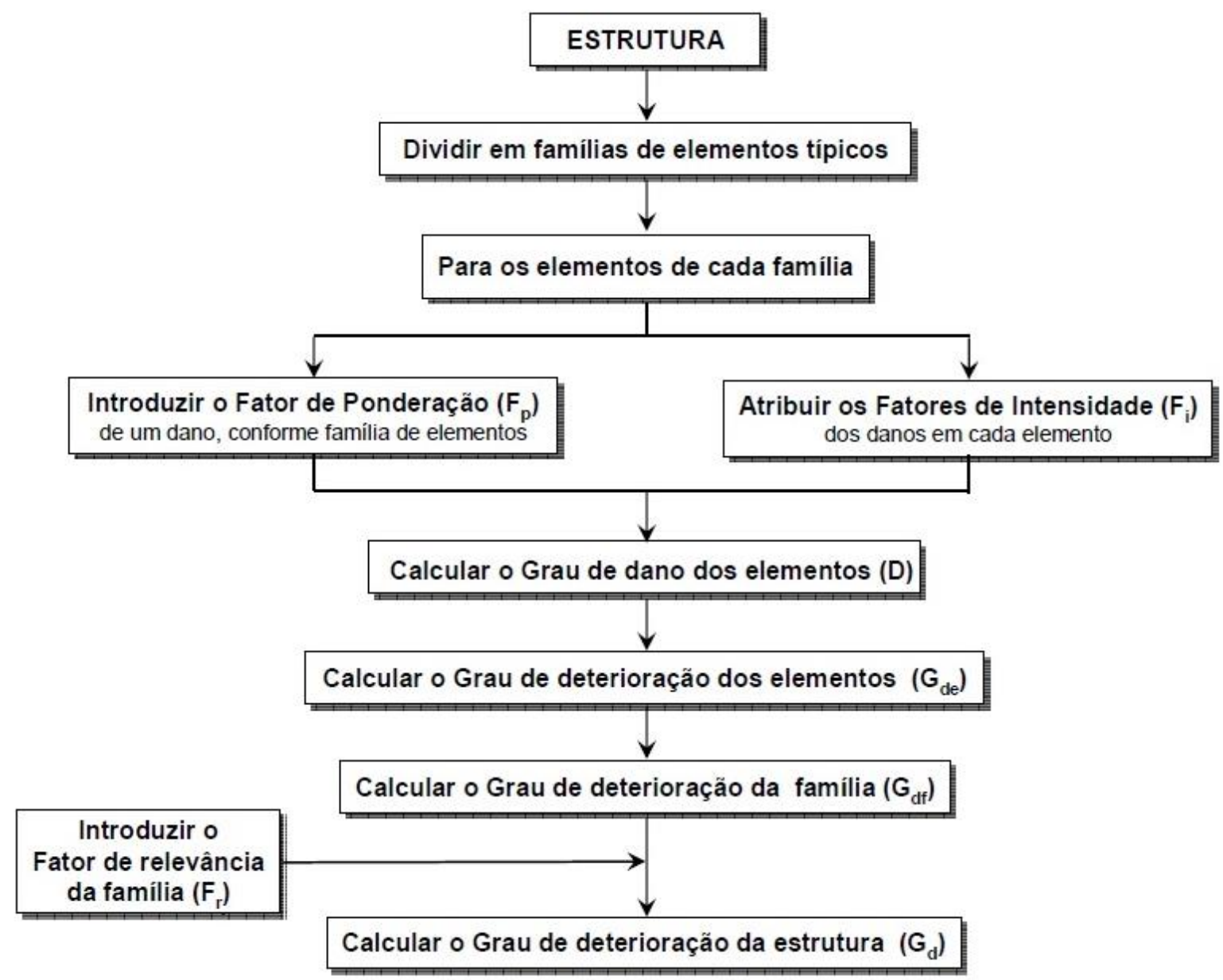

Figura 27 - Fluxograma para avaliação do grau de deterioração de estruturas de concreto da metodologia GDE/UnB - Fonseca (2007)

Para a correta aplicação dessa metodologia, as vistorias e a atribuição de pontuação do dano com base no "roteiro de inspeção" (Anexos A e B) onde constam, além das informações básicas sobre a estrutura, diversas planilhas com os dados necessários ao desenvolvimento do processo de avaliação da estrutura. $\mathrm{O}$ roteiro auxilia o engenheiro ou arquiteto a identificar os danos e suas causas, o grau de deterioração do elemento estrutural 
e de todo a estrutura e, sobretudo, na tomada de decisões para manutenção e recuperação das estruturas.

\subsubsection{Divisão em famílias de elementos}

Inicialmente, as estruturas de concreto da edificação em estudo são divididas em famílias de elementos típicos: Pilares; Vigas; Lajes; Cortinas (Muro Arrimo); Escadas / Rampas; Reservatório (superior e inferior); Bloco de Fundação; Junta de dilatação; Elementos de composição arquitetônica, de acordo com divisão feita por Fonseca (2007).

Para cada família de elemento é definida uma planilha onde são listadas as possíveis manifestações de danos, identificados nos elementos investigados, com o respectivo fator de ponderação, já definido em (Anexo A e B).

Para cada elemento investigado, é atribuída, pelos profissionais responsáveis e segundo critérios pré-estabelecidos constantes no Roteiro de Inspeção, uma pontuação que classifica o nível de gravidade de uma determinada manifestação de dano, segundo um fator de intensidade, onde para cada manifestação no elemento é calculado um grau de dano.

Castro (1994) explica que inicialmente calculam-se os graus de danos (D) para cada manifestação patológica, e em seguida o grau do dano no elemento investigado (Gde), um grau de deterioração individual e o consequente grau de deterioração da família de elementos (Gdf). Obtidos os graus de deterioração das diversas famílias que compõem a estrutura e entrando com um fator de relevância estrutural da família (Fr), previamente estabelecido segundo a importância relativa na funcionalidade e segurança estrutural, determina-se o grau de deterioração da estrutura (Gd).

Além das planilhas, o roteiro de inspeção também mostra as manifestações de danos mais frequentes em estruturas de concreto, são: carbonatação, cobrimento deficiente, desagregação, deslocamento por empuxo, desvio de geometria, eflorescência, esfoliação, fissuração inaceitável, flechas excessivas, infiltração, manchas, manchas de corrosão/corrosão de armaduras, obstrução das juntas de dilatação, presença de cloretos, recalque, segregação e sinais de esmagamento do concreto, etc.

\subsubsection{Fator de ponderação do dano (Fp)}

O Fator de Ponderação do Dano (Fp) quantifica a importância relativa de um determinado dano, no que se refere às condições gerais de estética, funcionalidade e segurança de um 
elemento estrutural. Para cada família de elementos, o Roteiro de Inspeção no Anexo B (Tabela B.2), apresenta planilhas com as possíveis manifestações de dano e os respectivos valores de Fp, numa escala de 0 a 5 .

\subsubsection{Fator de intensidade do dano (Fi)}

O Fator de Intensidade do Dano (Fi) é atribuído, a partir de vistorias, de acordo com a gravidade da manifestação em um elemento, conforme o Anexo B (Tabela B.1), classificando os danos em:

- $\quad$ Elemento sem lesões $(\mathrm{Fi}=0)$;

- Elemento com lesões leves $(\mathrm{Fi}=1)$;

- Elemento com lesões toleráveis $(\mathrm{Fi}=2)$;

- Elemento com lesões graves $(\mathrm{Fi}=3)$;

- Elemento com estado crítico $(\mathrm{Fi}=4)$.

O Anexo A apresentaram uma classificação dos tipos de danos mais frequentes em edificações usuais com estrutura de concreto armado, com uma identificação do nível de gravidade das lesões e descrição sucinta das intensidades das manifestações, conforme características específicas, para fins de aplicação desta metodologia.

\subsubsection{O Grau do dano (D) e Grau de deterioração de um elemento (Gde)}

O Grau do Dano (D) em um elemento é calculado a partir dos valores correspondentes do fator de ponderação $(0 \leq \mathrm{Fp} \geq 5)$ sendo pré-definido e correspondente a cada manifestação e do fator de intensidade do dano $(0 \leq \mathrm{Fi} \leq 4)$, este sendo atribuído pelo o responsável pela inspeção da estrutura. Utilizando as seguintes equações (1) e (2):

$$
\begin{aligned}
& \mathrm{D}=0,8 \mathrm{Fi} \mathrm{Fp} \quad \text { Para Fi } \leq 2,0 \\
& \mathrm{D}=(12 \mathrm{Fi}-28) \mathrm{Fp} \quad \text { Para Fi }>2,0
\end{aligned}
$$

Definido o Grau do Dano (D), calcula-se o Grau de deterioração de um elemento (Gde), pela seguinte equação (3):

$$
\text { Gde = Dmáx }\left\{1+\frac{\sum_{i-1}^{m} D i-\text { Dmáx }}{\sum_{i-1}^{\mathrm{m}} \mathrm{Di}}\right\rfloor
$$


Com o valor obtido pela equação (3) e com o auxílio da Tabela 12, se define o nível de deterioração do elemento, as ações a serem adotadas e prazo máximo para planejar as intervenções nos elementos estruturais investigados.

Tabela 12 - Classificação dos níveis de deterioração do elemento (Gde) - Fonseca (2007)

\begin{tabular}{|c|c|l|}
\hline $\begin{array}{c}\text { Nível de } \\
\text { deterioração }\end{array}$ & Gde & \multicolumn{1}{c|}{ Ações a serem adotadas } \\
\hline Baixo & $0-15$ & Estado aceitável. Manutenção preventiva. \\
\hline Médio & $15-50$ & $\begin{array}{l}\text { Definir prazo/ natureza para nova inspeção. } \\
\text { Planejar intervenção em longo prazo (máx. 2 anos). }\end{array}$ \\
\hline Alto & $50-80$ & $\begin{array}{l}\text { Definir prazo/ natureza para inspeção especializada detalhada. } \\
\text { Planejar intervenção em médio prazo (máx. 1 ano). }\end{array}$ \\
\hline Sofrível & $80-100$ & $\begin{array}{l}\text { Definir prazo/ natureza para inspeção especializada detalhada. } \\
\text { Planejar intervenção em curto prazo (máx. 6 meses). }\end{array}$ \\
\hline Crítico & $>100$ & Inspeção especial emergencial. Planejar intervenção Imediata. \\
\hline
\end{tabular}

\subsubsection{Grau de deterioração de uma família de elementos (Gdf)}

Para o cálculo do grau de deterioração de uma família de elementos (Gdf), são considerados apenas os elementos que apresentarem um nível de deterioração médio ou superior, ou seja, apenas os elementos com Gde $\geq 15$. Utilizar a seguinte equação (4):

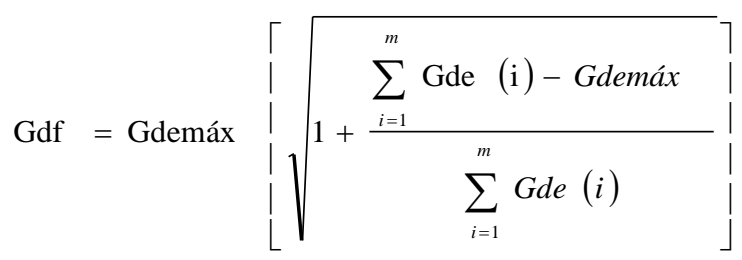

Portanto, quando os graus de deterioração dos elementos forem de Gde $<15$, para o grau de deterioração da família será de $\mathrm{Gde}=0$, não contribuindo para o cálculo final de deterioração da estrutura do edifício.

\subsubsection{Grau de deterioração da estrutura (Gd) e o Fator de relevância estrutural (Fr)}

O Grau de Deterioração da Estrutura $(\mathrm{Gd})$ é definido em função dos diferentes graus de deterioração das famílias dos elementos estruturais, com seus respectivos fatores de relevância estrutural (Fr), conforme a equação (5):

$$
\mathrm{Gd}=\frac{\sum_{i=1}^{k} F r(i) G d f(i)}{\sum F r(i)}
$$


O fator de relevância estrutural (Fr) determina a importância de contribuição que o elemento possui para garantir a estabilidade global da estrutura. Em posse disso, têm-se:

- Elementos de composição arquitetônica: $\mathrm{Fr}=1,0$;

- Reservatório superior e inferior: $\mathrm{Fr}=2,0$;

- Escadas/rampas, cortinas ou muro de arrimo, braços (hastes de sustentação da cúpulas) e fustes (pilar parede), junta de dilatação: $\mathrm{Fr}=3,0$;

- Lajes, bloco de fundações, vigas e pilares secundários: $\mathrm{Fr}=4,0$;

- Vigas e pilares principais: $\mathrm{Fr}=5,0$.

Assim adotando os fatores de relevância para cada família de elementos da estrutura do edíficio, é possível aplicar a formulação matemática e se obter o grau de deterioração da estrutura (Gd), conforme apresenta a Tabela 13.

Tabela 13 - Classificação dos níveis de deterioração da estrutura (Gd) - Fonseca (2007)

\begin{tabular}{|c|c|l|}
\hline $\begin{array}{c}\text { Nível de } \\
\text { deterioração }\end{array}$ & Gd & \multicolumn{1}{c|}{ Ações a serem adotadas } \\
\hline Baixo & $0-15$ & Estado aceitável. Manutenção preventiva. \\
\hline Médio & $15-50$ & $\begin{array}{l}\text { Definir prazo/ natureza para nova inspeção. } \\
\text { Planejar intervenção em longo prazo (máx. 2 anos). }\end{array}$ \\
\hline Alto & $50-80$ & $\begin{array}{l}\text { Definir prazo/ natureza para inspeção especializada detalhada. } \\
\text { Planejar intervenção em médio prazo (máx. 1 ano). }\end{array}$ \\
\hline Sofrível & $80-100$ & $\begin{array}{l}\text { Definir prazo/ natureza para inspeção especializada detalhada. } \\
\text { Planejar intervenção em curto prazo (máx. 6 meses). }\end{array}$ \\
\hline Crítico & $>100$ & Inspeção especial emergencial. Planejar intervenção Imediata. \\
\hline
\end{tabular}

\subsection{CONSIDERAÇÕES GERAIS SOBRE MANUTENÇÃO DE ESTRUTURAS}

\subsubsection{Conceitos importantes}

O objetivo é discutir estratégias de elaboração de um programa de manutenção, expondo os conceitos fundamentais sobre durabilidade, vida útil, desempenho em serviço, patologias e manutenção das estruturas. Contribuindo para traçar as melhores propostas de manutenção para a Torre de TV Digital de Brasília e garantir a extensão da sua vida útil.

\subsubsection{Durabilidade, vida útil, desempenho e patologias}

Segundo a norma ABNT NBR 6118:2014 (projeto de estruturas de concretoprocedimento), durabilidade consiste na capacidade da estrutura resistir às influências ambientais previstas e definidas em conjunto pelo autor do projeto estrutural e pelo 
contratante, no início dos trabalhos de elaboração do projeto. A norma também define diretrizes para a durabilidade das estruturas de concreto, onde faz menção as exigências de durabilidade, argumentando que as estruturas de concreto devem ser projetadas e construídas de modo que, sob as condições ambientais previstas na época do projeto e quando utilizadas conforme preconizado em projeto, conservem sua segurança, estabilidade e aptidão em serviço durante o prazo correspondente à sua vida útil.

A norma ABNT NBR 6118:2014 argumenta também por vida útil de projeto, entende-se o período de tempo durante o qual se mantêm as características das estruturas de concreto, sem intervenções significativas, desde que atendidos os requisitos de uso e manutenção prescritos pelo projetista e pelo construtor, bem como de execução dos reparos necessários decorrentes de danos acidentais.

A norma afirma que o desempenho em serviço, consiste na capacidade da estrutura manterse em condições plenas de utilização durante sua vida útil, não podendo apresentar danos que comprometam em parte ou totalmente o uso para o qual foi projetada.

No entanto, sabe-se que as estruturas de concreto ao longo do tempo apresentam danos e se deterioram, contribuindo para a queda do desempenho estrutural, perda da durabilidade e redução de sua vida útil das estruturas que compõem o edifício. Todos esses conceitos estão relacionados com patologia das construções (Figura 28) que se ocupa do estudo das origens desses danos, formas de manifestação, consequências e mecanismos de ocorrência das falhas e dos sistemas de degradação das estruturas.

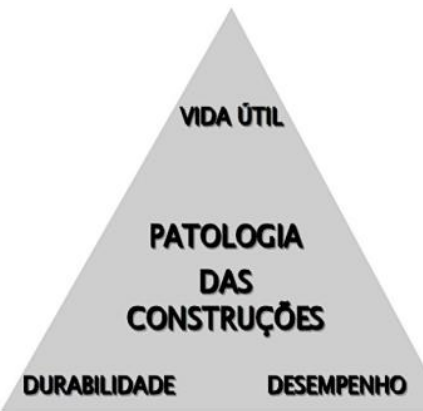

Figura 28 - Conceitos relacionados com patologias das construções

Porém para recuperar a estrutura é importante conhecer o mecanismo de cada dano, suas origens e consequências, para que sejam feitas as intervenções necessárias e corretas, e para alcançar o desempenho satisfatório da estrutura ao longo do tempo, é necessário realizar uma série de atividades rotineiras que tem por finalidade garantir a vida útil da estrutura, denominadas de manutenção, como mostra a Figura 29. (SOUZA e RIPPER, 1999). 


\section{Desempenho}

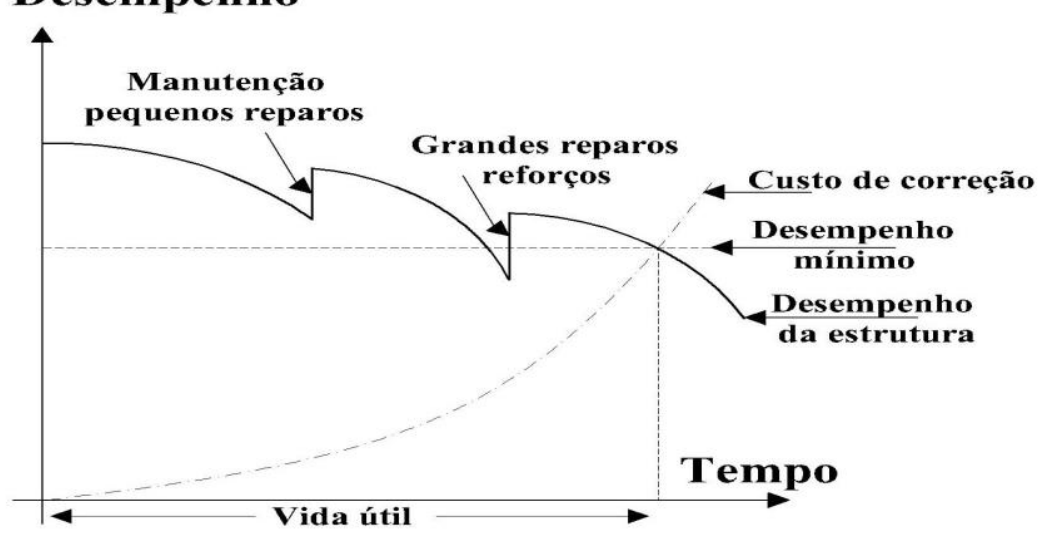

Figura 29 - Fases de desempenho de uma estrutura durante sua vida útil - adaptada do CEB (1992) e Helene (1992)

Pode-se observar que quanto mais cedo forem realizadas as correções dos danos, mais efetivo, mais fácil e de menos custos será o procedimento de manutenção, com um desempenho estrutural mais satisfatório.

Segundo Helene (1992), a "Lei de Sitter" que possui o nome de seu autor, mostra para o caso especifico das manutenções das estruturas os custos crescendo segundo uma progressão geométrica com o passar do tempo. As etapas construtivas e de uso são divididas em quatro períodos, correspondente ao projeto, à execução, à manutenção preventiva, efetuada antes dos três anos, e à manutenção corretiva, efetuada após surgimento dos problemas. Segundo SITTER, colaborador do CEB - Comité EuroInternacional du Béton, afirma que adiar uma intervenção significa aumentar os custos diretos em uma progressão geométrica de razão cinco, como mostra a Figura 30.

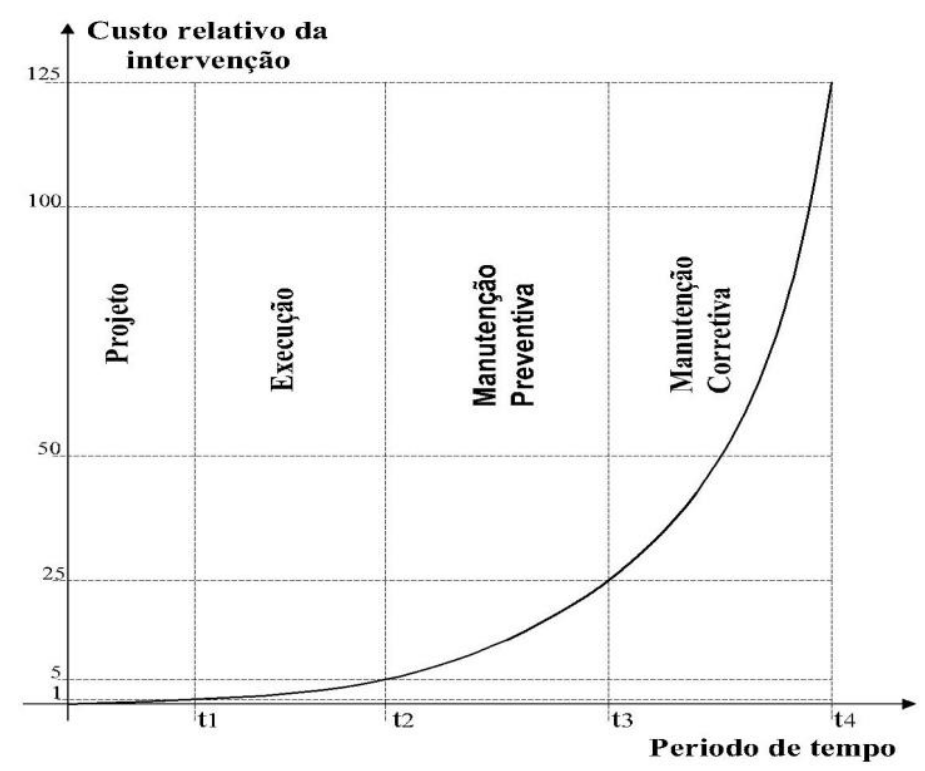

Figura 30 - Lei de evolução de custos - adaptado de SITTER (1984) 
De acordo com a "Lei de Sitter", toda medida tomada em nível de projeto com objetivo de aumentar a proteção e a durabilidade da estrutura, implica num custo que pode ser associado a um valor unitário. No entanto, se essas medidas de proteção e durabilidade forem efetuadas durante a execução implica em um custo 5 vezes superior ao custo que teria acarretado se essa medida tivesse sido tomada a nível de projeto. Já com a manutenção preventiva durante o período do uso estará associado a um custo de 25 vezes superior aquele que teria acarretado uma decisão de projeto para obtenção do mesmo grau de proteção e durabilidade. E se não forem tomadas as medidas previstas quanto as correções das manifestações patológicas e a manutenção corretiva for prorrogada, ela pode assumir um caráter extensivo e com esse fator podendo evoluir para 125 vezes o valor dos recursos iniciais utilizado no edifício.

Portanto, é importante temos a conscientização da necessidade de uma manutenção periódica para garantir a longevidade da obra, pois a ocorrência de danos e defeitos estruturais tem menores efeitos e custos menos onerosos se forem descobertos e resolvidos logo no início, se resumindo em um ditado popular muito conhecido "não deixes para amanhã o que se podes fazer hoje”, por cinco vezes menos.

\subsubsection{Manutenção das estruturas}

Segundo a norma ABNT NBR 5674:1999 (Manutenção de edificações-procedimento), manutenção é o conjunto de atividades a serem realizadas para conservar ou recuperar a capacidade funcional da edificação e de suas partes constituintes de atender as necessidades e segurança dos seus usuários.

A manutenção de uma estrutura compreende um conjunto de atividades técnicas a serem desempenhados em duas etapas:

Manutenção preventiva - envolve o conjunto de ações técnicas realizadas para prevenir a ocorrência de falhas ou lesões, tomadas com antecedência e a previsão de intervalos de tempo, durante o período de uso da estrutura. Baseia-se no diagnóstico apropriado se sintomas patológicos mediantes inspeções periódicas competentes, condicionadas pela a natureza das ações, agressividade do ambiente e quantidade de vidas envolvidas (FIP,1988).

Manutenção corretiva - conjunto de ações técnicas cuja realização é decidida a partir do diagnóstico de problemas, que causem o mau desempenho ou afetem a essência funcional 
da edificação. As ações podem se propor a recuperar, reforçar ou mesmo substituir parte (s) do sistema.

O gráfico da Figura 31 relaciona o uso (desempenho) da estrutura com sua vida útil (tempo), considerando o desempenho de uma estrutura sujeita apenas a efeitos de seu desgaste natural, passando por manutenção periódica preventiva. Observa-se que sempre haverá uma perda residual de desempenho estrutural. Uma vez ultrapassado o desempenho limite previsto para a manutenção preventiva é necessário programar a realização de recuperação para manutenção corretiva, antes de se ultrapassar o limite crítico de aceitação.

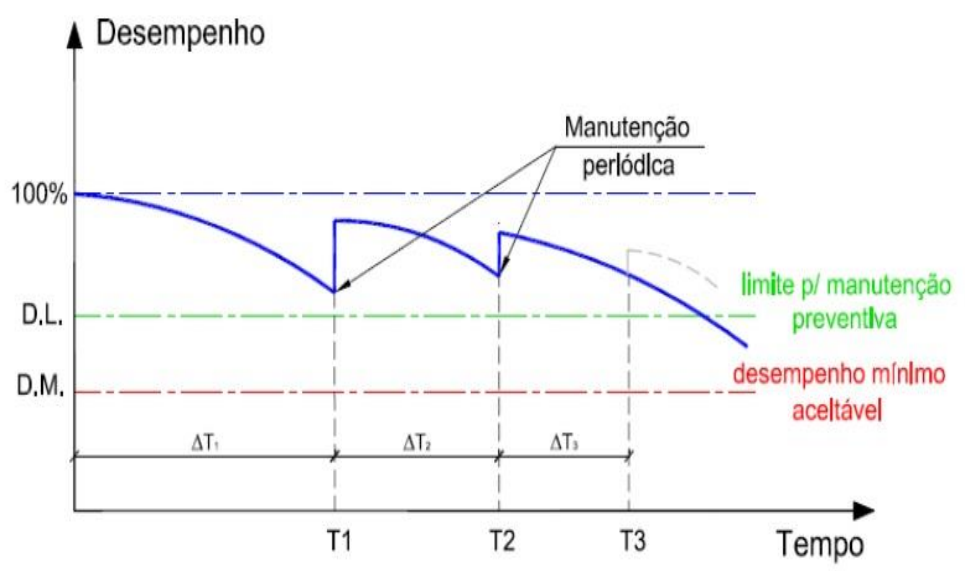

Figura 31 - Modelo de desempenho de uma estrutura sob manutenção periódica - Moreira (2007) apud Cunha (2006)

Os intervalos de tempo para a realização de inspeções estão apresentados na Tabela 14, e são baseados na metodologia da Federação Internacional da Protensão para Estruturas de Concreto Armado e Protendido - FIB (1988). Onde são definidos intervalos de acordo com categoria e a classificação da estrutura em classes, combinações com o tipo de condição ambiental e de carregamento. Da seguinte maneira:

a) Classes de estruturas:

Classe 1 - onde a ocorrência de ruptura pode ter consequências catastróficas e/ou onde a funcionalidade da estrutura é de vital importância para a sociedade;

Classe 2 - onde a ocorrência de ruptura pode custar vidas e/ou onde a funcionalidade da estrutura é de considerável importância;

Classe 3 - onde é improvável que a ocorrência de uma ruptura leva a consequências fatais e/ou onde um período com a estrutura fora de serviço possa ser tolerado. 
b) Classes de Inspeção:

Rotineira - realizadas em intervalos regulares, com planilhas específicas da estrutura, elaboradas conjuntamente por técnicos responsáveis pelos projetos e pela manutenção.

Extensiva - realizada em intervalos regulares, alternadamente com as rotineiras, com o objetivo de investigar mais minuciosamente os elementos e as características dos materiais componentes da estrutura.

c) Tipos de Condições Ambientais e de carregamento:

Muito severa - o ambiente é agressivo com carregamento cíclico com possibilidade de fadiga;

Severa - o ambiente é agressivo com carregamento estático ou o ambiente é normal com carregamento cíclico com possibilidade de fadiga;

Normal - o ambiente é normal com carregamento estático.

Tabela 14 - Indicação de intervalos de inspeção (em anos) - FIP (1988)

\begin{tabular}{|c|c|c|c|c|c|c|}
\hline \multicolumn{7}{|c|}{ Classes de Estruturas } \\
\hline \multirow{3}{*}{$\begin{array}{c}\text { Condições } \\
\text { Ambientais e de } \\
\text { Carregamento }\end{array}$} & \multicolumn{2}{|c|}{1} & \multicolumn{2}{|c|}{2} & \multicolumn{2}{|c|}{3} \\
\hline & Inspeção & Inspeção & Inspeção & Inspeção & Inspeção & Inspeção \\
\hline & Rotineira & Extensiva & Rotineira & Extensiva & Rotineira & Extensiva \\
\hline Muito severa & $2 *$ & 2 & $6 *$ & 6 & $10 *$ & 10 \\
\hline Severa & $6^{*}$ & 6 & $10 *$ & 10 & $10^{*}$ & - \\
\hline Normal & $10 *$ & 10 & $10 *$ & - & $* *$ & $* *$ \\
\hline
\end{tabular}

As inspeções ou investigações da estrutura podem ser complementadas com informações obtidas por ensaios específicos, que geralmente envolvem um processo interativo, nos quais os resultados dos testes sugerem a necessidade de maiores investigações. 


\section{TORRE DE TV DIGITAL DE BRASÍLIA}

A Torre de TV Digital, o último projeto arquitetônico de Oscar Niemeyer executado em Brasília, foi feita para dar uma solução técnica através do compartilhamento da transmissão de sinais de imagens digital entre todas as redes de televisão do Brasil. A localização e altura da Torre foram definidas pela Agência Nacional de Telecomunicações (ANATEL), órgão responsável por promover o desenvolvimento das telecomunicações no país.

O mais recente monumento de Brasília deu-se início à construção em 15 de junho de 2009 e inaugurado em 21 de abril de 2012, juntamente com o aniversário de 52 anos da Capital. A Torre está localizada no planalto da região mais elevada da capital, Alto Colorado, no setor habitacional, Taquari, Trecho 2, Quadra 200, Conjunto 1 e 2, próximo a Sobradinho, em um terreno de $40.000 \mathrm{~m}^{2}$ e aproximadamente $20 \mathrm{~km}$ do centro de Brasília, como pode se ver na Figura 32.

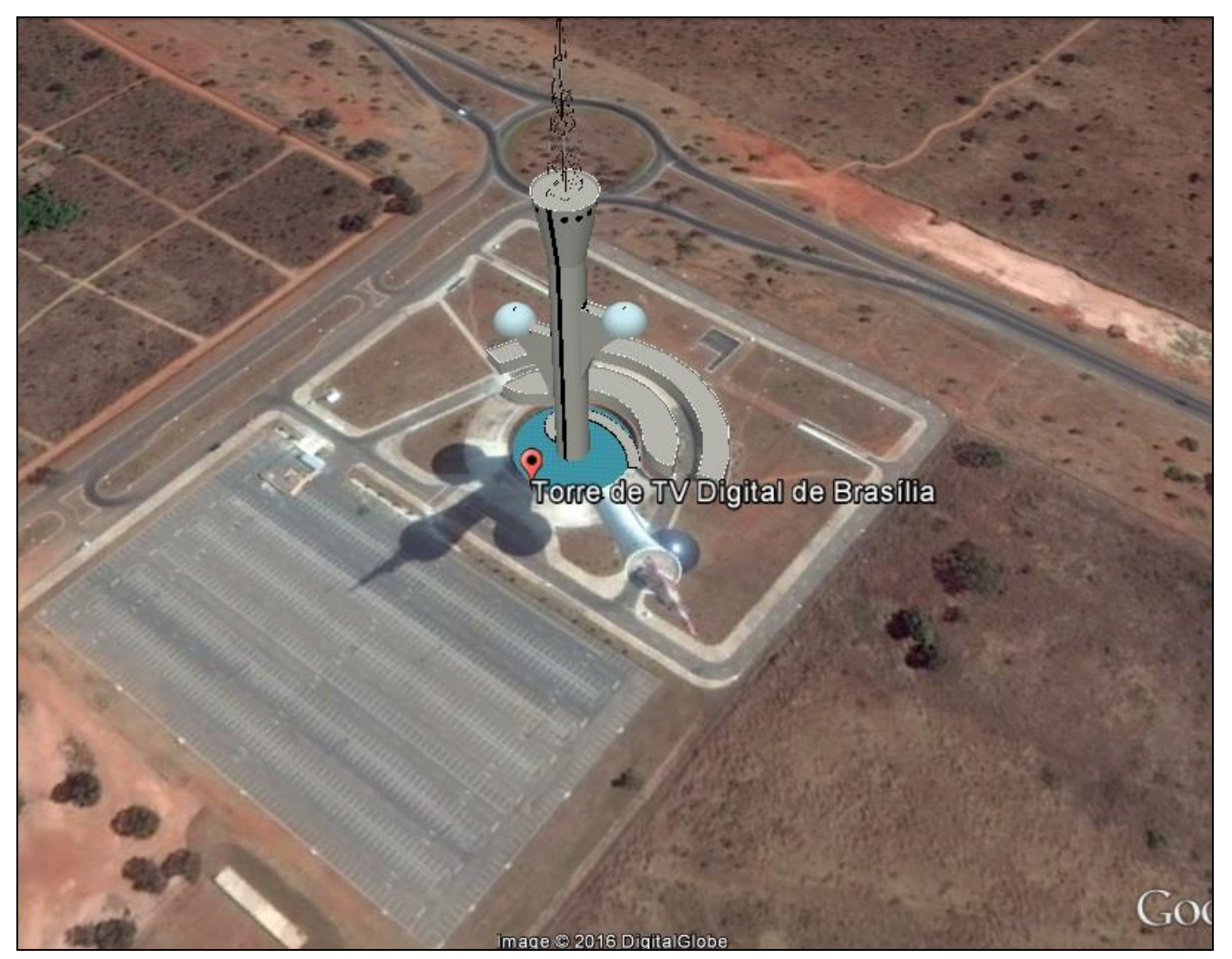

Figura 32 - Localização via satélite da Torre de TV Digital de Brasília, coordenadas geográficas: $15^{\circ} 41^{\prime} 31^{\prime}$ S e $47^{\circ} 51^{\prime} 13^{\prime}$ W -

Disponível em: < Google Earth >. Acesso em: 02/04/2016 


\subsection{PROJETO ARQUITETÔNICO}

A Torre de TV Digital projetada pelo o arquiteto Oscar Niemeyer e calculada pelo o engenheiro José Carlos Sussekind se divide em estrutura externa e interna. A parte externa é composta por estacionamento e acesso, bloco de retransmissoras, bloco de apoio à visitação, rampa de acesso à torre e a própria torre, que se subdivide em cúpula bar cultural, cúpula centro de exposição, mirante e antena; e a parte interna que é formada pelo subsolo e suas rampas de acesso, onde acomoda as máquinas e a central técnica. Na planta de situação (Figura 34), pode-se observar essa divisão de forma explicativa.

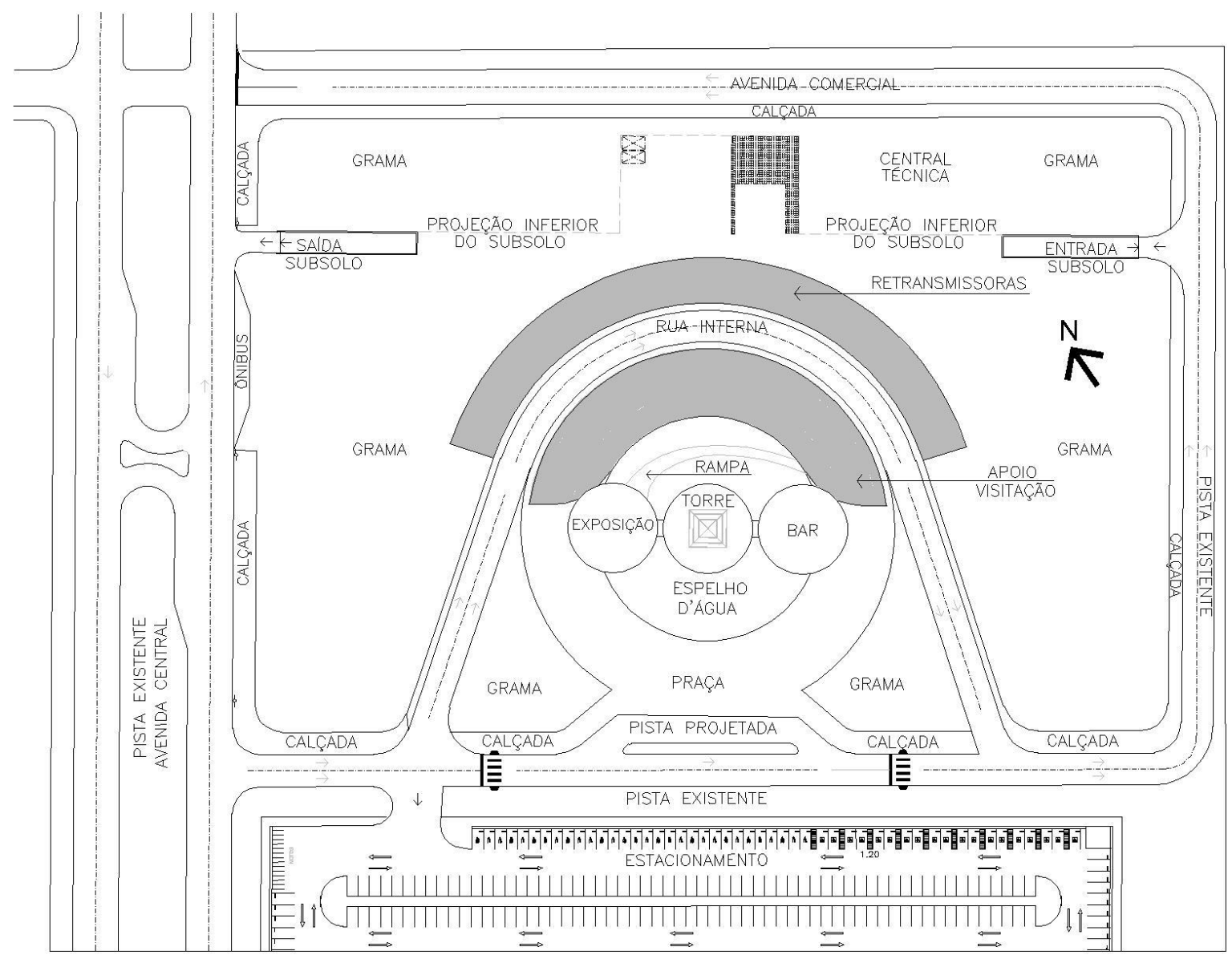

Figura 33 - Planta de situação da estrutura da Torre de TV Digital de Brasília (NOVACAP) 
Segundo Gorgulho (2012), a estrutura da Torre vista em um formato de uma "flor", dividese em fuste, braços, cálice e cúpula. O fuste é a base ou parede circular de concreto com 12 $\mathrm{m}$ de diâmetro e não se altera até a altura de $86 \mathrm{~m}$. Os braços nascem no fuste, são duas "hastes", como uma espécie de consoles, para sustentar e abrigar dois espaços cobertos: as duas cúpulas. As cúpulas estão dispostas em dois lados: de um lado, aos $60 \mathrm{~m}$, fica um centro de exposições e do outro lado, aos 80 m, um bar e café. Aos $110 \mathrm{~m}$ de altura, há um mirante com vista de $360^{\circ}$. O cálice é a região onde o diâmetro é variado, aumentando de $12 \mathrm{~m}$ na cota de $86 \mathrm{~m}$ para $20 \mathrm{~m}$ na cota de $120 \mathrm{~m}$. Já o trecho entre a cota de $120 \mathrm{~m}$ e a cota de 182 m é formado por uma estrutura metálica, como pode-se observar na Figura 34.

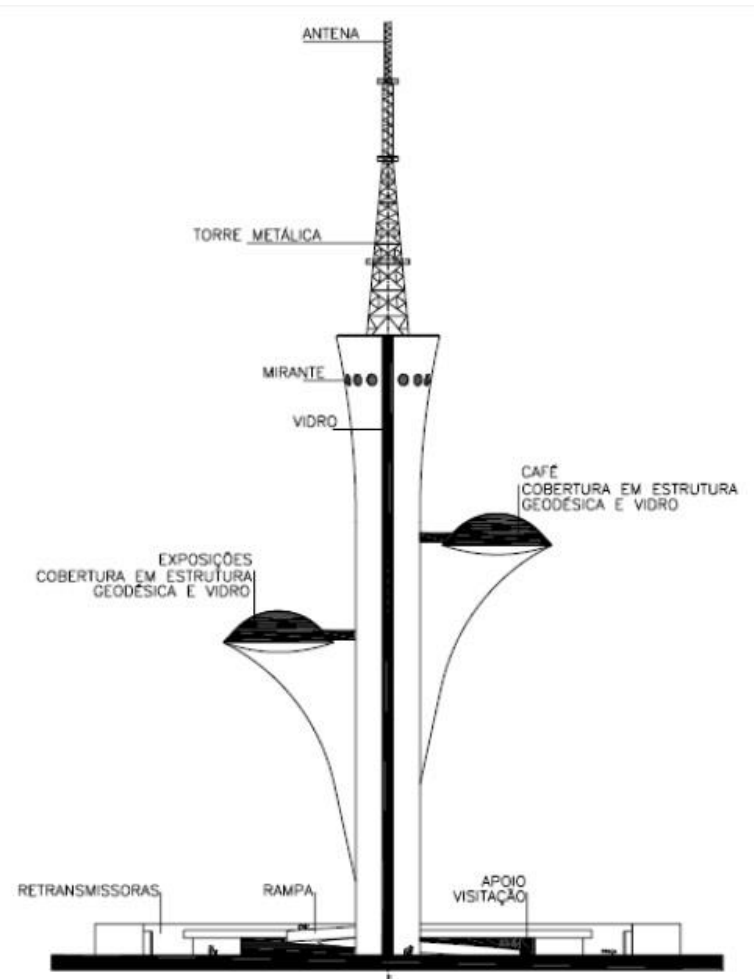

Figura 34 - Fachada principal da estrutura da Torre de TV Digital de Brasília (NOVACAP)

\subsection{ESTUDO DA AÇÃO DO VENTO NA ESTRUTURA}

Em março de 2009, após a solicitação da empresa Casuarina, responsável pela elaboração do projeto estrutural da Torre de TV Digital, o diretor técnico de fiscalização da TERRACAP, o arquiteto Luís Antônio Almeida Reis enviou um oficio para o presidente da NOVACAP, José Alves de melo Júnior, pedindo providência para a contratação do estudo do túnel de vento para o monumento. 
A empreiteira da obra Consórcio Mendes Jr. Atrium, ainda na fase de projeto contratou o ensaio junto às empresas LSE- Laboratório de Sistemas Estruturais Ltda e IPT- Instituto de Pesquisas Tecnológicas, que ficaram responsáveis pela realização do ensaio em túnel de vento de um modelo reduzido. O protótipo da Torre foi construído na escala 1:150, juntamente com a torre metálica na qual foi fixada a antena, em que apresenta dimensões do modelo reduzido com 1,20 m de altura total e $8 \mathrm{~cm}$ de diâmetro do fuste da base, como mostra a Figura 35.

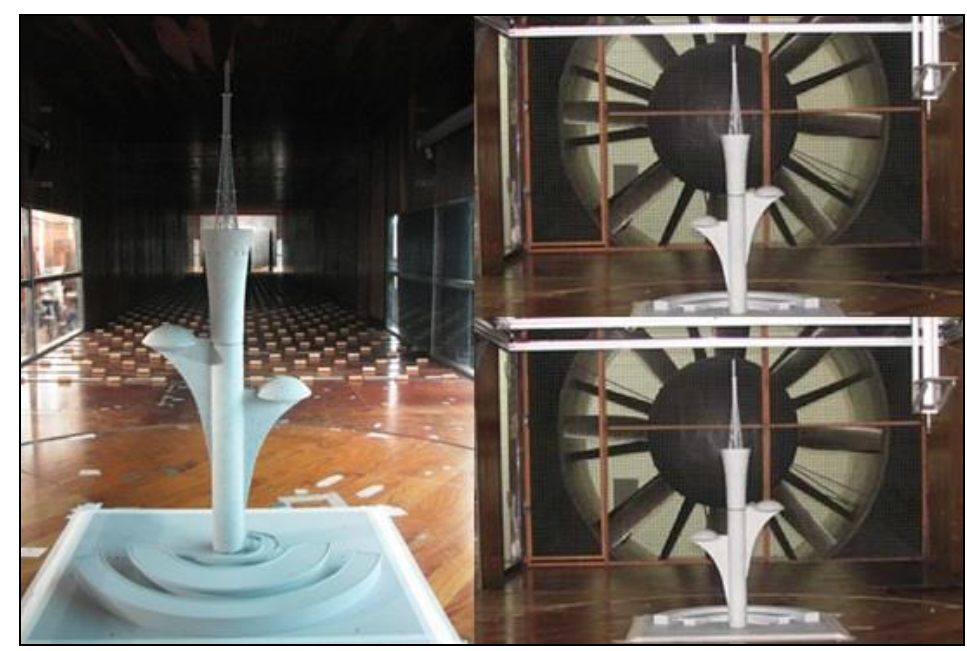

Figura 35 - Protótipo para a realização do ensaio no túnel de vento - Gorgulho (2012)

Foram realizados ensaios de protótipos com e sem antena, com incidências entre $0^{\circ}$ e $360^{\circ}$, para velocidade de $40 \mathrm{~m} / \mathrm{s}$, superior à velocidade determinada para Brasília, de $35 \mathrm{~m} / \mathrm{s}$, conforme a norma da ABNT NBR 6123:1988, e obtiveram as forças, momentos fletores e torçores na fundação da Torre, e assim verificando com segurança os efeitos das cargas de vento após a construção.

Na publicação da Revista Techne - Pini (2011), o projetista estrutural Mário Terra, comparando os resultados obtidos com os coeficientes de arrasto que havia considerado, observou que tinham valores acima do apontado pelo ensaio, ou seja, estavam a favor da segurança. E por fim, foram mantidos os valores calculados pelas normas e livros obtidos pelos os engenheiros envolvidos. Confirmou-se que a pior solicitação na fundação era com vento perpendicular aos braços da Torre, incidência de $90^{\circ}$.

Segundo Gorgulho (2012), a equipe técnica do IPT responsável pelo estudo foi composta por: Gilder Nader, Antônio Luiz Pacífico, Marcos Tadeu Pereira (doutores em engenharia); Paulo José Saiz Jabardo (mestre em engenharia); Fábio Souza ( engenheiro mecânico) e Josiel Alves (técnico). 


\subsection{ESTRUTURA DA FUNDAÇÃ̃}

A fundação e estruturas de concreto foi calculada pelo engenheiro José Carlos Sussekind e sendo dimensionada para sustentar a Torre. Neste projeto há a existência de um subsolo de $10 \mathrm{~m}$ de profundidade, que acomoda parte das instalações e os equipamentos de transmissão. Devido este subsolo as fundações não começam no nível do terreno "isso aumenta o esforço da fundação, pois o momento é ainda maior" afirma Mário Terra na Revista Techne - Pini (2011), projetista da Avantec, que trabalhou junto com o calculista.

A Fundação da Torre tem um bloco de concreto com diâmetro de $25 \mathrm{~m}$ por $4,5 \mathrm{~m}$ de altura, que está a 13,6 m de profundidade do nível do solo. Este bloco está apoiado em 246 estacas do tipo raiz, com $41 \mathrm{~cm}$ de diâmetro e $12 \mathrm{~m}$ de profundidade cada. A escolha desse sistema se deu por conta do tipo de solo no local, com arenito intercalado com argila, pois "uma estaca convencional não penetraria nesse solo, não dispondo de uma superfície com característica rochosa", argumenta o engenheiro.

Mário Terra explica que para garantir a estabilidade da Torre, "todo o esforço e o peso do material exigem uma área para distribuir a carga e esse diâmetro do bloco não foi mais que suficiente para instalar todas as estacas, pois elas precisam ser distribuídas com espaçamento mínimo exigido pela norma, e não havia como colocar menos estacas, por conta do grande esforço na base".

O fuste que nasce do bloco de fundação é feito de parede circular de concreto armado de espessura de $50 \mathrm{~cm}, 40 \mathrm{~cm}$ e $30 \mathrm{~cm}$, sendo mais espesso na base e menos no topo. Os braços de sustentação das cúpulas também feitos em concreto armado têm $25 \mathrm{~cm}$ de espessura e as nervuras horizontais dos braços com espessura de $20 \mathrm{~cm}$ e o prato que apoia a cúpula possui $25 \mathrm{~cm}$ de espessura.

\subsection{PLANEJAMENTO EXECUTIVO}

Para a construção da Torre foram realizados um projeto e um planejamento executivo de todos os processos construtivos, para definir as principais etapas da obra, como fundação, estruturas de concreto, vedações, instalações, acabamento e outras etapas necessárias para a construção da obra.

O planejamento envolveu também questões técnicas da construção, questões de saúde e condições de trabalho para cada um dos 741 operários, bem como atendimento seguro e 
perfeito para os visitantes. Todos os planejamentos executivos dos processos construtivos estão listados no livro "Flor do Cerrado" de Gorgulho (2012) e foram divididos em 10 etapas, apresentadas a seguir (Figura 36):

$1^{\circ}$. Etapa:

Dar-se o início e conclusão da escavação da base e do subsolo da Torre de TV Digital.

$2^{\circ}$. Etapa:

Execução e conclusão das 246 estacas tipo raiz, com um diâmetro de $41 \mathrm{~cm}$ e com três perfuratrizes.

$3^{\circ}$. Etapa:

Fase de arrastamento das estacas, regularização do terreno e execução do concreto magro, e construção do bloco da base com 150 toneladas de aço e $2000 \mathrm{~m}^{3}$ de concreto utilizado na concretagem.

$4^{\circ}$. Etapa:

São construídos três lances de parede em forma circular convencional da cota $-9,0 \mathrm{~m}$ até a cota de 0,0 m, onde cada lance têm a altura de 3,00 m, e nessa etapa também é feito a concretagem dos poços dos elevadores. Logo após a conclusão dos lances de paredes, é feito o aterro do entorno, exceto a galeria técnica que fica no subsolo. Com previsão da montagem de fôrmas deslizantes e início do seu deslizamento em 20/10/2009.

$5^{\circ}$. Etapa:

Na parte externa dar-se início e conclusão da fôrma deslizante até a cota de 85,99 m, onde o diâmetro permanece inalterado. Já no fuste interno, começa a concretagem da laje na cota de 13,95 m, com uma evolução média de 10 dias por lance de laje.

Na cúpula de exposição que fica na cota de $60 \mathrm{~m}$ e a cúpula do bar cultural que fica na cota de $80 \mathrm{~m}$, dão início à montagem do cimbramento metálico, com perfis estruturais na cota de $72 \mathrm{~m}$ para a execução da viga parede entre as duas cúpulas, vigas e lajes de suporte para os pilares. Com previsão em 23/11/2009.

$6^{\circ}$. Etapa:

Ainda na parte externa da torre, inicia a execução das plataformas e bandejas na cota 95,85 $\mathrm{m}$ para iniciar a execução do cálice, que tem diâmetro variado. Com previsão em 21/12/2009. 
No braço da cúpula de exposição, início da montagem do cimbramento metálico e concretagem até a cota $32,85 \mathrm{~m}$, deixando passagem para execução da rampa de acesso à Torre. Já no braço da cúpula do bar, montagem do cimbramento metálico até a cota de 32 , $85 \mathrm{~m}$. Dando continuidade no fuste interno, concretagem das lajes na cota $23,40 \mathrm{~m}$ e 32,85 m, com uma evolução média de 15 dias por lance de laje. Além de pilares e paredes internas entre lajes das cotas $23,40 \mathrm{~m}$ e $32,85 \mathrm{~m}$.

$7^{\circ}$. Etapa:

No fuste interno, concretagem das lajes da cota 42,30 m e na cota 51,75 m, e ainda na parte interna no cálice, concretagem das lajes na cota de 89,55 m e 99,00 m. Logo depois, a concretagem da parede externa do cálice até a cota 110,20 m.

Na cúpula de exposição e cúpula do bar cultural início da montagem do cimbramento metálico e concretagem da estrutura até a cota de $51,75 \mathrm{~m}$.

$8^{\circ}$. Etapa:

No fuste interno, concretagem das lajes da cota 51,75 m e na cota de $61,20 \mathrm{~m}$, e no cálice também na parte interna, concretagem da laje na cota de 110,20 m e a conclusão da concretagem da parede interna do cálice até a cota 110,20 m. Já na parede externa do cálice, conclusão da concretagem até a cota 120,10 m.

Na cúpula de exposição, montagem do cimbramento metálico até a cota de 61,20 m e concretagem da estrutura sob ou abaixo as lajes da cúpula. Na cúpula do bar, montagem do cimbramento metálico até a cota de 70,65 m e concretagem da estrutura até a cota de 61,20 $\mathrm{m}$.

\section{$9^{\circ}$. Etapa:}

No fuste interno, concretagem da laje na cota de $80,10 \mathrm{~m}$ e no cálice também na parte interna, concretagem da laje na cota $118,95 \mathrm{~m}$.

$\mathrm{Na}$ cúpula de exposição, concretagem das lajes na cota de $61,20 \mathrm{~m}$, com previsão em 15/03/2010. Além de montagem da cúpula geodésia em estrutura metálica tubular revestida com vidro SKN de $10 \mathrm{~mm}$, com previsão em 31/03/2010. Já na cúpula do bar, começa montagem do cimbramento metálico até a cota de $80,10 \mathrm{~m}$ e concretagem da estrutura da laje sob ou abaixo da cúpula. 
$10^{\circ}$. Etapa:

$\mathrm{Na}$ cúpula de exposição, execução do acabamento, e na cúpula do bar montagem da cúpula. Além do descimbramento das cúpulas, pintura e colocação dos vidros. Finalizando com conclusão da montagem da torre metálica, com previsão da obra está concluída em 20 de abril de 2012.

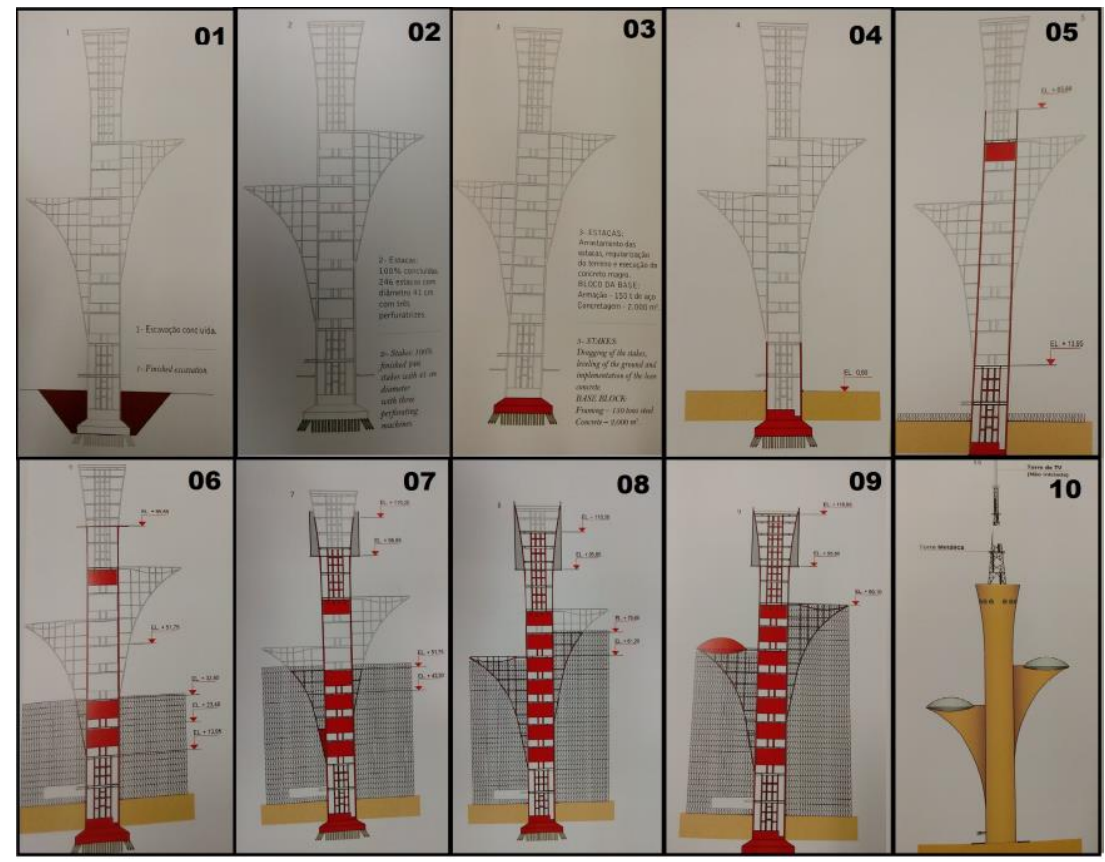

Figura 36 - Etapas dos planejamentos executivos dos processos construtivos da Torre de TV Digital de Brasília - adaptado Gorgulho (2012)

\subsection{EXECUÇÃo}

A empresa responsável pela construção da obra foi a empreiteira Consórcio Mendes Júnior Atrium, sobre a responsabilidade do engenheiro Bruno Zauli. A construção teve- início em 15 de junho de 2009 e foi inaugurada em 21 de abril de 2012.

No livro de Gorgulho (2012) o engenheiro Bruno Zauli argumenta que a obra é especialíssima por vários motivos: pela concepção fantástica do projeto do arquiteto Oscar Niemeyer; pela tecnologia que o Consórcio Mendes Júnior Atrium teve que desenvolver e pela logística do processo construtivo.

\subsubsection{Execução das estacas}

Para execução das estacas, inicialmente foi realizada uma escavação de 13,6 metros de profundidade e 25 metros de diâmetro. Em seguida foram executadas 246 estacas do tipo raiz, cada uma com 12 metros de profundidade, para apoiar a base de concreto que tem 
dimensões de $25 \mathrm{~m}$ de diâmetro por 4,5 m de altura, servindo de sustentação para a Torre. Como pode-se observar na Figura 37.

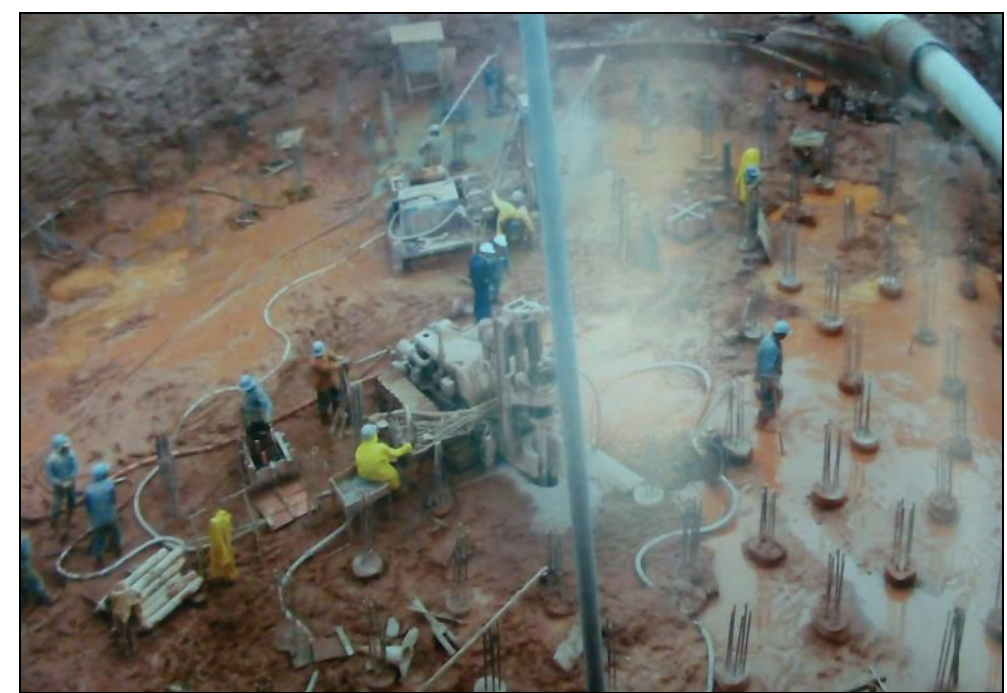

Figura 37 - Execução das estacas - Gorgulho (2012)

Segundo Joppert (2007) as estacas raiz são fundações moldada "in loco", executadas através de perfuratrizes rotativas ou percussivas, utilizando-se de revestimento ao longo do furo, visando garantir a integridade de seu fuste. Após a perfuração, a estaca é armada e preenchida com argamassa fluida.

Esse tipo de estaca possui alta capacidade de cargas com recalques muitos reduzidos, podem ser executadas em qualquer tipo de terreno com direções especiais e exigem poucas perturbações em ambientes de vizinhança.

De acordo com Venâncio (2008) a execução da estaca-raiz, compreende as seguintes sequência: locação, perfuração, armação, concretagem, extração do revestimento e injeção de ar comprimido.

1. Locação das estacas: Primeiramente deve-se realizar a locação dos pontos onde serão executadas as estacas, de acordo com as exigências do projeto de fundação.

2. Perfuração do solo ou rocha: A perfuração do furo na vertical ou inclinada é executada mediante a utilização de perfuratrizes rotativa hidráulica ou roto percussiva. A perfuração em solo é realizada por rotação de tubos com o auxílio de circulação de água, que é injetada pelo interior deles e retorna a superfície entre a face externa do tubo e o solo. Os elementos tubulares de aço rosqueáveis, possui na sua extremidade uma coroa de perfuração para facilitar a penetração. 
3. Colocação da armadura: Terminada a perfuração da estaca, deve-se continuar a injetar água, sem avançar a perfuração, a fim de promover a limpeza do furo. Posteriormente é colocada a armadura metálica no interior do tubo de perfuração. A armadura pode ser constituída de uma ou mais barras montadas em feixes ou gaiolas conforme especificado no projeto estrutural.

3. Injeção da argamassa: Concluída a limpeza do furo e acolocação da armadura, coloca-se o tubo (de aço galvanizado ou PVC rígido) de concretagem até o fundo da perfuração. A partir deste tudo é injetada armassa (areia e cimento) preparada em um misturador de alta turbulência. A injeção da argamassa é processada de baixo para cima, o que provoca o deslocamento da água existente no furo para fora. Esta operação é executada com o furo totalmente revestido com o tubo de perfuração, portanto, realizado com o máximo de segurança para a continuidade da moldagem da estaca.

Quando o tubo de perfuração estiver totalmente preenchido com argamassa, a sua extremidade superior é tamponada e aplicada uma pressão de ar comprimido. Esta pressão provoca a penetração da argamassa no solo aumentando substancialmente o atrito lateral e garantindo a continuidade da estaca.

4. Retirada do revestimento: Inicia-se a retirada dos tubos ou camisa de aço por intermédio de macacos hidráulicos, para não haver contaminação da argamassa com a terra ou solo. Procedendo-se a cada trecho de elementos de tubo sacado, a complementação do nivel de argamassa no interior do tubo e aplicação de uma nova pressão. Continuando o procedimento até a finalização da estaca com a retirada de todos os tubos de perfuração.

\subsubsection{Execução do fuste}

No livro de Gorgulho (2012) o engenheiro Bruno Zauli argumenta que "o fuste é o corpo da coluna, ou seja, o corpo principal da Torre, desde a base até o cálice”.

$\mathrm{Na}$ execução do fuste, até a cota de $85 \mathrm{~m}$, foi adotado o processo de fôrma metálica deslizantes, essa tecnologia permitiu que a obra subisse entre $1,20 \mathrm{~m}$ a 1,50 m por dia. $\mathrm{O}$ fuste ou parede circular de concreto armado tem espessura variada, sendo $50 \mathrm{~cm}, 40 \mathrm{~cm}$ e $30 \mathrm{~cm}$. Bruno Zauli conta que "a fôrma é abastecida manualmente com concreto e se desloca verticalmente por acionamento dos macacos hidráulicos, abastecendo novos espaços e assim por diante até sua cota máxima de deslizamento" 
Os serviços de execução do fuste foram dividos em três etapas: o lançamento e adensamento; a execução da armadura projetada e o acabamento da superfície do concreto. Segundo Gorgulho (2012) compreendendo os seguintes passo a passo:

1. Descarga do concreto do caminhão betoneira para as jiricas (carrinho de mão com maior capacidade, transporte pesado e ágil);

2. Transporte manual das jiricas até o elevador de cargas e posteriormente o transporte até a plataforma de trabalho;

3. Retirada das jiricas do elevador de carga e lançamento do concreto na fôrma, empurrar com o auxilio de pás, para dentro da fôrma, parte do concreto que fica na plataforma de trabalho;

4. Inicia-se o adensamento por meio de vibradores elétricos;

5. Limpeza das bordas das fôrmas para evitar que o resto do concreto acumulado ali segue e cause rachuras e brocas.

O concreto utilizado é especial de alto desempenho com um "Slump 5", que utiliza aditivos retardadores de pega para diminuir o tempo de início da cura. A Figura 38, mostra a execução do início do fuste na base da Torre, e o fuste já construído até o início do cálice, ou seja, até a cota de 85 metros.

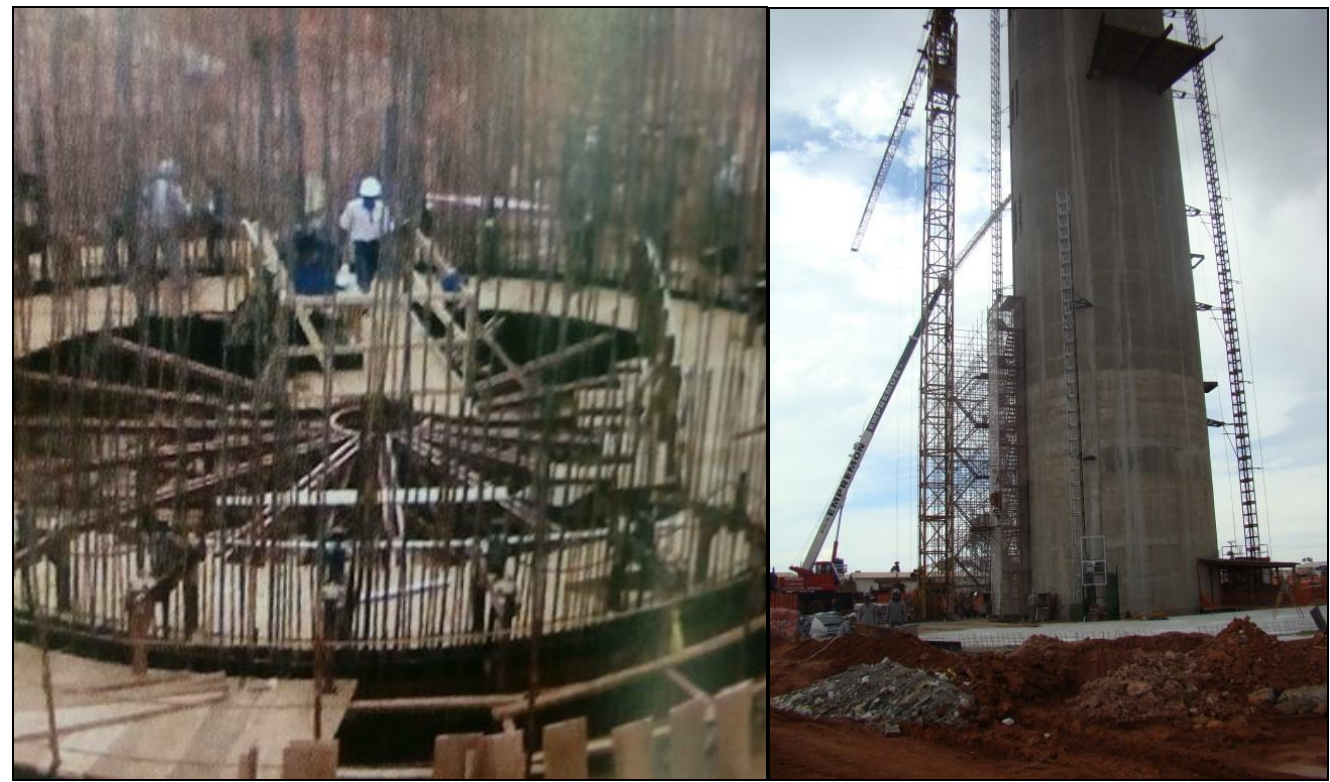

Figura 38 - Erguimento da armadura do fuste da base em concreto e aço - (ArPDF) 


\subsubsection{Execução da ferragens}

O livro de Gorgulho (2012) aborda que a execução da armadura é dividida em quatro taferas executadas no local da obra, o que requer armadores em todas as etapas:

1. Transporte dos vergalhões da central de armação até a plataforma de trabalho, que é constante;

2. Posicionamento dos ferros verticais, que exige que se tenha uma equipe na plataforma superior da fôrma, cuidando apenas do posicionamento;

3. Colocação dos ferros horizontais, que são os mais complexos, devido ao pouco espaço e pelo fato de a fôrma estar deslizando.

4. Posicionamento e colocação das armaduras das lajes, vigas, e parades de sustentação das cúpulas.

\subsubsection{Execução do cálice}

Conforme Gorgulho (2012), na parte do cálice o diâmetro é variado com 12 m na cota 85 $\mathrm{m}$, aumentando até $20 \mathrm{~m}$ na cota de $120 \mathrm{~m}$. Para sua execução foi utilizada fôrma do tipo auto elevatória, onde primeiro é realizada a montagem inicial da fôrma, depois o basculamento, içamento, travamento e concretagem. Essas etapas foram repetidas várias vezes, com a fôrma sempre se apoiando na anterior. Como mostra a Figura 39.

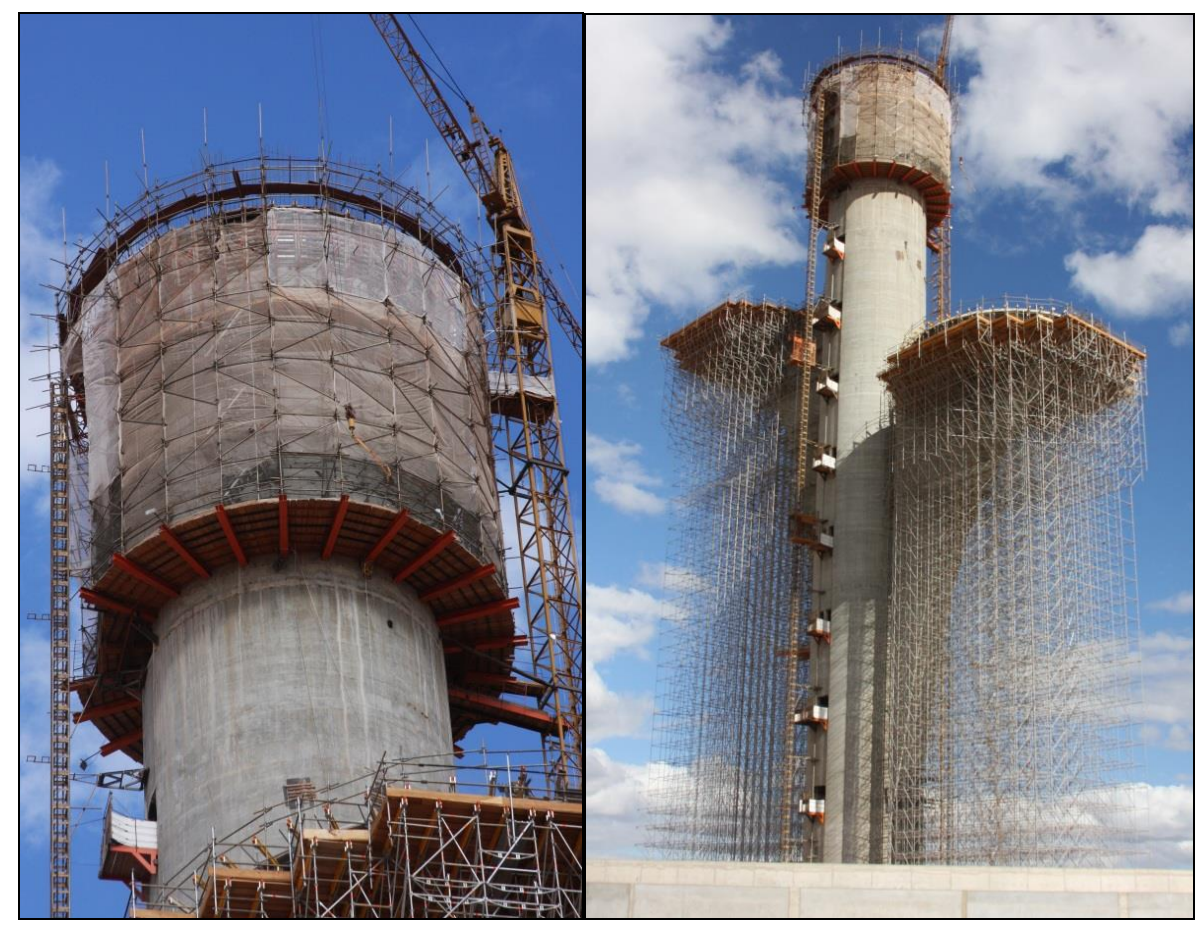

Figura 39 - Detalhe da construção do cálice da Torre de TV Digital de Brasília - (ArPDF) 


\subsubsection{Execução dos Braços}

De acordo Gorgulho (2012) para a execução dos braços externos que compõem a estruturas que sustentam as cúpulas geodésica na cota de $60 \mathrm{~m}$ e na cota de $80 \mathrm{~m}$, foi adotado o processo de fôrma metálica autotrepante, como mostra a Figura 40.

Inicialmente foi executada a montagem da fôrma, a armação e concretagem. Após essa concretagem, um novo jogo de fôrma foi montado, apoiado no primeiro e logo após, foi feita uma nova concretagem. Essa sequência segue com a desmontagem da primeira fôrma e remontagem sobre a de cima, ocorrendo novamente a concretagem, seguindo-se assim até a etapa final.

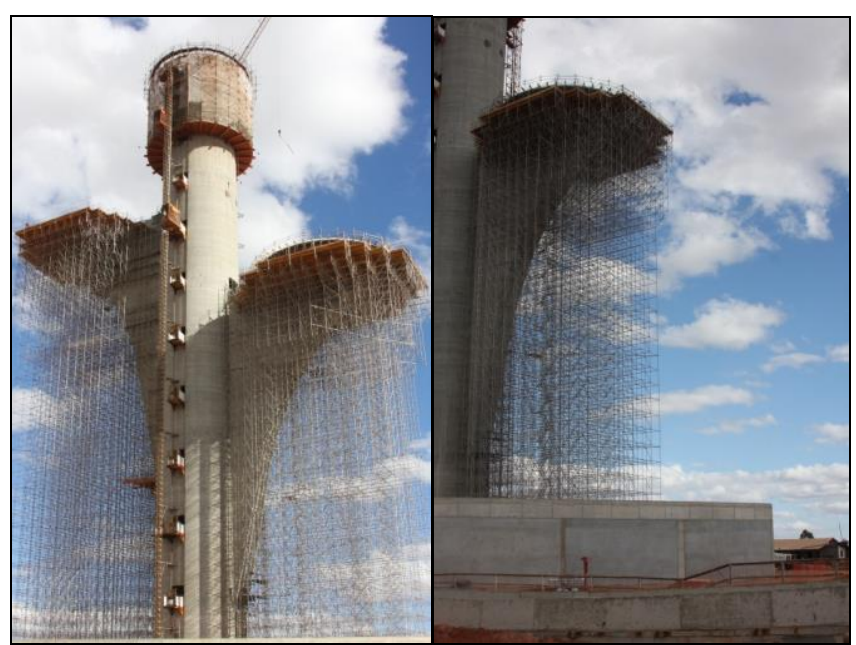

Figura 40 - Execução dos braços externos da Torre de TV Digital de Brasília - (ArPDF)

A Figura 41 mostra a execução dos braços laterais que sustentam as cúpulas, onde no nível superior de cada braço foi feito uma protensão, exatamente onde estão os tabuleiros que formam as estruturas da cúpula, responsável por absorver as cargas dos consoles. $\mathrm{Na}$ Revista Techne - Pini ( 2011), o engenheiro Mário Terra, comenta que a protensão foi uma maneira de reduzir a armadura que une os braços ao fuste de concreto, para evitar a ocorrência de fissuras e outras patologias.

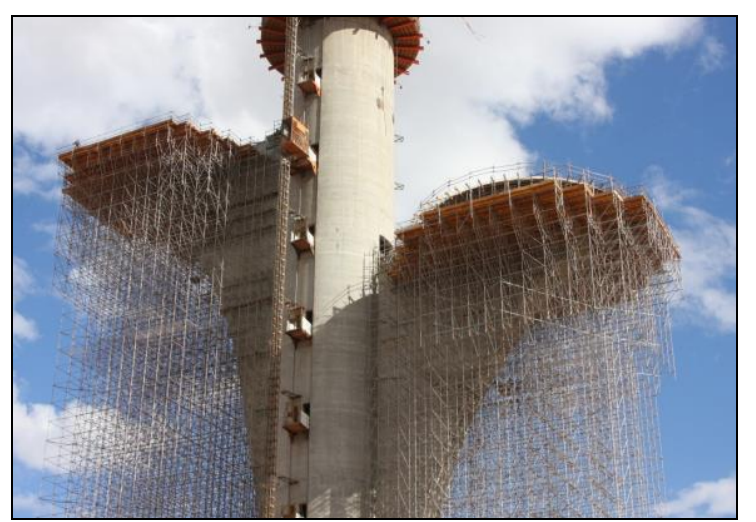

Figura 41 - Execução dos braços de apoio das cúpulas - (ArPDF) 


\subsubsection{Execução das calotas esféricas}

De acordo com Gorgulho (2012) durante o processo executivo das calotas esféricas que receberão as cúpulas metálicas geodésicas (Figura 42), foram utilizadas fôrmas de madeira cambotadas revestidas com compensado plastificado. $\mathrm{O}$ engenheiro Bruno Zauli, argumenta sobre calotas esféricas, que sua "forma externa é de um segmento esférico, como um guarda-chuva de cabeça para baixo, onde as hastes são as vigas da estrutura, e que em cada braço contém uma cúpula geodésica metálica revestida com vidro laminado, com conforto térmico e luminoso adequado".

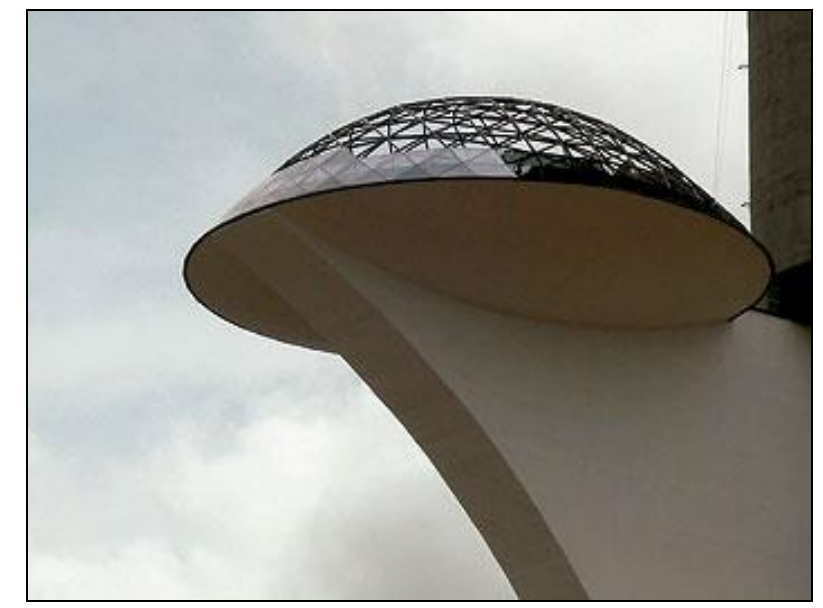

Figura 42 - Calotas esféricas, com cúpulas metálica geodésica -

Disponível em: < http://techne.pini.com.br/engenharia-civil/168/flor-do-cerrado-proximo-a-brasiliaestrutura-de-182-287821-1.aspx>. Acesso em: 18/01/2017

Segundo Gorgulho (2012):

"O arquiteto-escultor Chileno Luis alberto Rivas Rocco, dimensinou as fôrmas que moldariam as lajes de apoio das cúpulas, dos braços e da rampa de acesso a torre. Ele detalhou sarrafo por sarrafo, cambota por cambota para construir o ângulo perfeito da laje de suporte das cúpulas. Dimensinou cada peça de madeira com cuidado e acompanhou a montagem das fôrmas em solo antes de iniciar sua montagem definitiva".

\subsubsection{Execução das cúpulas geodésicas}

Segundo Gorgulho (2012) o arquiteto Felipe Aceto Ferraz, diretor operacional da Avec Verre Design Produtos Especiais Ltda, empresa responsável pelas execução das cúpulas, argumenta que as cúpulas são calotas esféricas de $21 \mathrm{~m}$ de diâmetro com superfície composta por segmentos planos determinados a partir de um icosaedro que é uma forma tridimensional de 20 faces triangulares equiláteros iguais.

A estrutura das cúpulas é metálica, e é formada por tubo de aço carbono patinável de alta resistência, diferente do aço comum. O aço patinável não tem um processo contínuo de 
oxidação (corrosão), pois a primeira camada de ferrugem (pátina) funciona como uma proteção que impede o avanço da corrosão.

O vidro é ligado a estrutura metálica de forma totalmente elástica, pois sua borda é constituída por perfis de borracha de silicone que posteriormente são colocadas aos tubos de aço. Toda movimentação provocada por vento e dilatação térmica dos materiais é absorvidas pela camada elástica que envolve o vidro.

De acordo com Gorgulho (2012) os vidros da cúpulas tem 113 medidas triangulares diferentes, totalizando 1026 peças. Apresentam propriedades térmicas muito eficientes, pois controlam a luminosidade, reduzem a entrada de calor do sol no ambiente interno. Em comparação ao vidro incolor comum, o vidro das cúpulas rejeitam mais de $60 \%$ da energia térmica que seria transmitidas.

Todos os vidros são laminados, cada placa é formada por duas laminas de vidro unidas por um filme de polivinilbutiral. Em caso de quebra, o vidro não espalha, assim como parabrisa de um automóvel.

\subsubsection{Execução da rampa de acesso a Torre}

Na Revista Techne - Pini ( 2011) mostra a rampa de acesso à torre feita em concreto armado, e compõe-se de duas curvas helicoidais de $65 \mathrm{~m}$ de extensão. Sua estrutura é um caixão perdido e protendido pelo eixo central de três vãos, como pode-se observar na Figura 43.

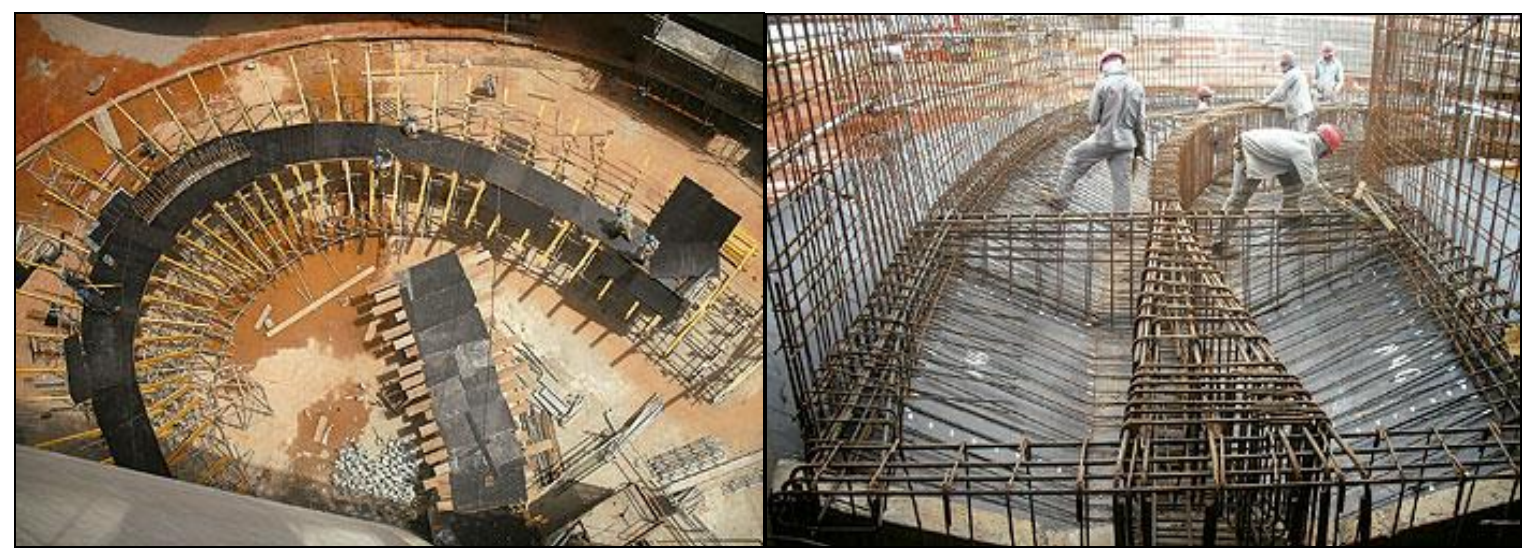

Figura 43 - Execução das rampas de acesso a Torre -

Disponível em: < http://techne.pini.com.br/engenharia-civil/168/flor-do-cerrado-proximo-a-brasiliaestrutura-de-182-287821-1.aspx >. Acesso em: 18/01/2017 


\subsubsection{Execução da torre metálica}

A torre métalica nasce nas vigas de uma laje inferior à laje de cobertura, onde é feita a sua fixação de maneira reforçada devido a força crítica do vento, utilizando-se chumbadores passantes pesado que envolve essas duas lajes, uma espécie de elemento de ancoragem para fixação dessa estrutura. Como mostra a Figura 44, a torre metálica é fixada nas vigas dessa laje inferior, onde é travada e ancorada, atravessa a laje de cobertura rumo ao topo. Na Revista Techne- Pini (2011), o engenheiro Mário Terra conta que foi o detalhe que melhor atendeu à estrutura metálica e permitiu o detalhamento da estrutura de concreto para garantir a fixação.
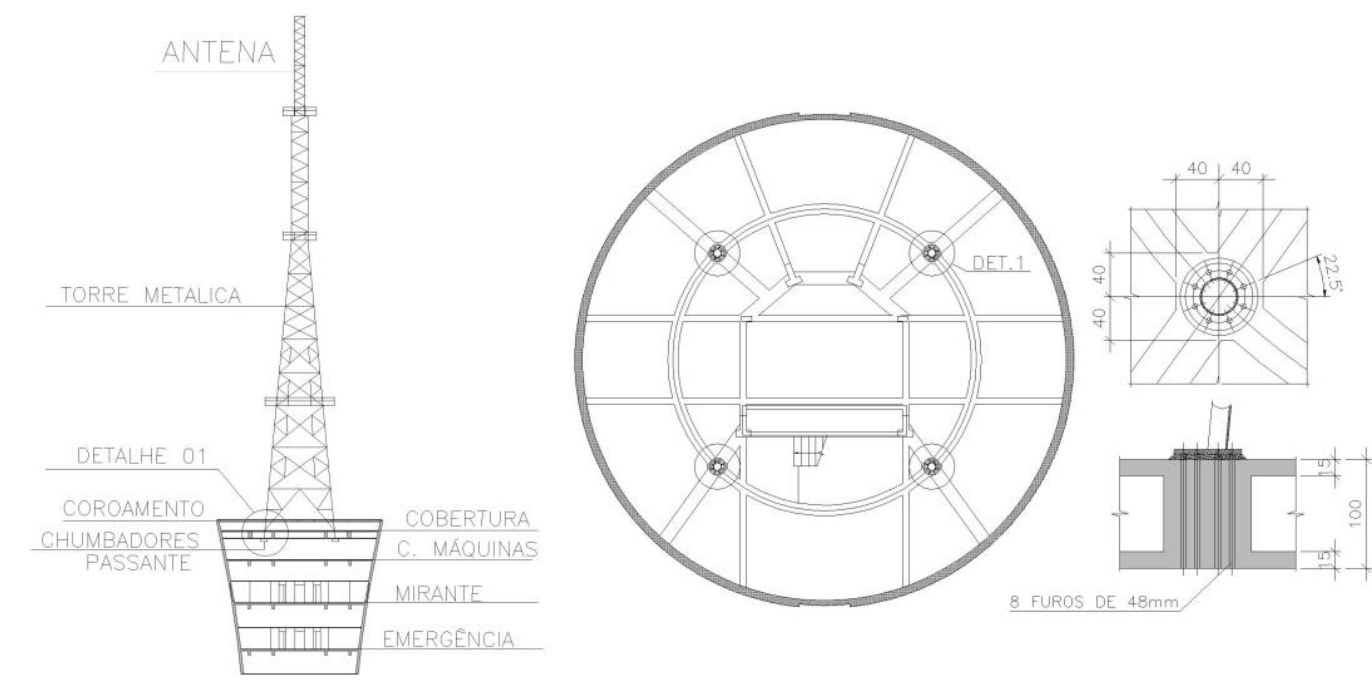

Figura 44 - Fixação da torre metálica, detalhe 1 - retirado do projeto executivo

A obra seguiu o cronograma de acordo com o planejamento executivo, com conclusão da sua execução e a sua inauguração na data prevista, em 21 de abril de 2012, ao mesmo tempo em que a capital do Brasil completava 52 anos, como mostra a Figura 45.

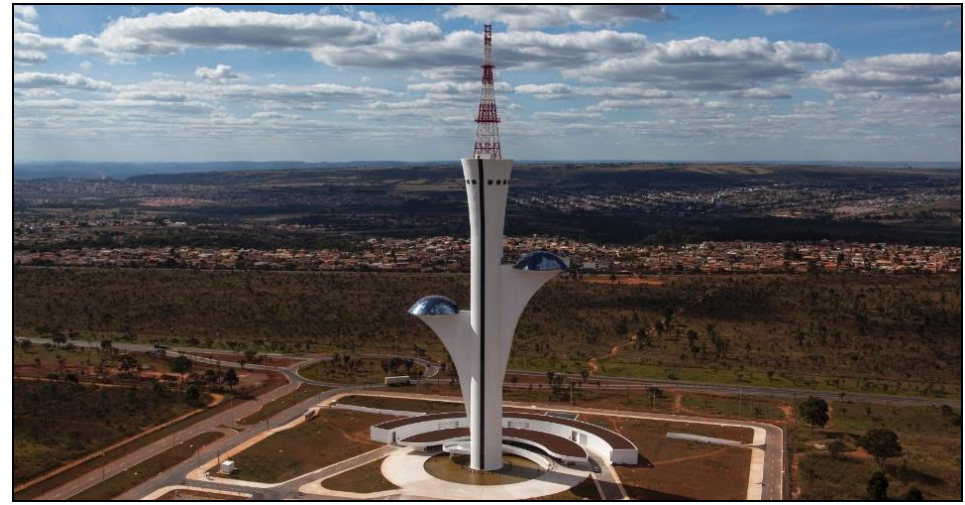

Figura 45 - Torre de TV Digital de Brasília finalizada -

Disponível em: http://convergecom.com.br/wp-content/uploads/2015/05/Torre-TV-digitalBras\%C3\%ADlia.jpg, acesso em: 02/04/16 
Para sua construção, foram empregados processos tecnológicos, com a instalação de sensores de fibra ótica para realizar o monitoramento em tempo real da estrutura de concreto.

Na Revista Techne- Pini (2011), Luiz Eduardo Texeira Ferreira, coordenador de monitoramento de estruturas da Falcão Bauer, empresa que realizou o gerenciamento da implantação do monitoramento estrutural, explica que os sensores mediram as vibrações estruturais, os deslocamentos, as deformações especificas, a temperatura, acelerações e velocidade do vento e poro-pressão, contribuindo para se ter uma ideia clara da saúde da edificação.

\subsection{SUSTENTABILIDADE E AUTOSSUFICIÊNCIA}

\subsubsection{Reuso da água da chuva}

A Torre conta com medidas sustentáveis que visam o reuso dos recusos pluviais, contribuindo para sua sustentabilidade, e principalmente para o meio ambiente.

Segundo Gorgulho (2012):

"Toda água pluvial coletada da laje de cobertura da Torre, das edificações de apoio e das vias internas a edificação é reutilizada, principalmente para a irrigação do jardim. A água de procedência pluvial passa por um sistema de filtragem, sendo conduzida a dois reservatórios com capacidade de $45 \mathrm{~m}^{3}$ cada, localizados no subsolo, ou seja, o sistema de captação de águas pluviais permite o armazenamento e reutilização de 90 mil litros de água".

\subsubsection{Sistema de esgoto}

Outra medida de autossificiência e sustentabilidade utilizada no monumento, foi o sistema de esgoto a vácuo.

De acordo com Gorgulho (2012):

"O sistema de esgoto de todo o complexo da Torre funciona a vácuo, o que permite uma economia de água de até $90 \%$ em relação ao sistema de esgotamento convencional. Após coletado, o esgoto é conduzido a uma central, localizada na área técnica no subsolo. Desta central o esgoto é bombeado a um reservatório com capacidade de 11.200 litros, depois passa por um filtro e segue por gravidade para as valas de infiltrações que estão distribuídas sob a grama do jardim. O efluente tratado que sai do filtro é rico em nutrientes, o que favorece a área irrigada do jardim, com aproximadamente $200 \mathrm{~m}^{20}$. 


\subsection{INTERVENÇÕES}

Segundo Gorgulho (2012) o processo de construção da Torre de TV Digital de Brasília foi marcado por atrasos e problemas, pois a obra deveria ser inaugurada em 21 de abril de 2010, aos 50 anos da capital, porém, entraves jurídicos e administrativos deixaram a conclusão da obra mais distante e fizeram com que sua inauguração fosse adiada e somente dois anos depois foi aberta, em 21 de abril de 2012.

Em 2012 o monumento mesmo inaugurado, apresentava alguns detalhes a se fazer. Esses detalhes trouxeram grandes problemas, e no ano de 2014 o monumento foi fechado para o público após uma fiscalização técnica realizada pelo Tribunal de Contas do Distrito Federal. Segundo o TCU, os detalhes inadequados no projeto e na execução da obra causavam danos que poderiam trazer prejuízos de segurança e durabilidade do monumento ao longo do tempo.

Todas essas informações foram extraídas de entrevista realizada na Rádio Revista Brasília, publicada no ano de 2015, onde o diretor de edificações da Companhia Urbanizadora da Nova Capital do Brasil (NOVACAP), explica todos os problemas na estrutura da Torre de TV Digital, baseado em laudo feito pelo corpo técnico do Tribunal de Contas de União do Distrito Federal.

$\mathrm{Na}$ entrevista, o diretor da NOVACAP argumenta que os fiscais observaram que o projeto não previu a captação e a drenagem das águas pluviais nas passarelas de acesso das cúpulas do bar e exposição. As águas das chuvas não tinham para onde escoar adequadamente, o que ocasionou várias infiltrações. Essas infiltrações poderiam causar a corrosão da armadura e provocar trincas ou fissuras na estrutura, e assim, podendo comprometer a estabilidade global do edifício ao longo dos anos. Além dos problemas citados acima, a empreiteira/consórcio Mendes Júnior Atrium também ficou responsável pelos os seguintes reparos da obra:

- Reajustes do projeto do sistema de combate a incêndio e conclusão da sua execução, substituição de bombas principais por bombas mais potentes e readequação da distribuição até os diversos hidrantes ao longo de toda a estrutura;

- Revisão, teste e conclusão de pequenos reparos do sistema de ar condicionado;

- Fechamento do shaft (abertura) existente na cobertura da torre, por onde passam os cabos das antenas das emissoras de televisão; Além da substituição de placas de 
gesso do forro de alguns pavimentos e pintura de todo forro dos pavimentos, bem como limpeza e substituição de grelhas de captação de água no subsolo;

- Revisão do sistema de chuveiros automáticos (splinkers) e revisão de toda iluminação, com reparo em todos os projetores de plasma que estavam queimados.

Somente em 2015 a obra foi reaberta à visitação para o público, após ter sido feito todos os reparos impostos pelo TCU. Porém no ano de 2016 que foi realizada as olimpíadas no Rio de Janeiro e que teve vários eventos espalhado no país, como na cidade de Brasília que pôde receber milhares de turistas, mas devido o não funcionamento normalizado do monumento às visitas a Torre de TV Digital de Brasília foram prejudicadas e número de visitantes foi menos do que o esperado. 


\section{AVALIAÇÃO DA ESTRUTURA DA TORRE DE TV DIGITAL DE BRASÍLIA}

\subsection{INTRODUÇÃO}

A avaliação da estrutura ou descrição da situação física atual da Torre é feita a partir da utilização da metodologia GDE/UnB, desenvolvida pelo programa de Pós-graduação em Estruturas e Construção Civil-PECC/UnB, onde a partir de inspeções (observação visual) e formulações matemáticas define-se o grau de deterioração da estrutura, incluindo identificação dos danos, deterioração e possíveis fenômenos progressivos inseridos nos elementos estruturais.

\subsection{CARACTERÍSTICAS DA INSPEÇÃO}

Para a realização da inspeção na estrutura da Torre de TV Digital e para efeito de análise da estrutura, é importante identificarmos algumas das suas principais considerações:

1) Data da inspeção: realizada no dia 23 de agosto de 2016, com início às 10:30 horas e término às 15:30 horas;

2) Finalidade: avaliar a condição atual da Torre seguindo a metodologia GDE/UnB, a partir de uma vistoria para a observação de possíveis danos e possíveis fenômenos progressivos inseridos nos elementos estruturais.

3) Responsáveis pela inspeção: Fellipe Sobreira Soares, Arquiteto e Urbanista, graduado pelo Instituto Camilo Filho-ICF e mestrado pelo o programa de Pós-graduação em Estruturas e Construção Civil-PECC/UnB; e Nicolas Roa Rojas, Engenheiro Civil, graduado pela Univerdad del Cauca e mestrado pelo o programa de Pós-graduação em Estruturas e Construção Civil-PECC/UnB;

4) Brigadista: Bombeiro Civil Donisete Macêdo, responsável pelo o acompanhamento dos profissionais envolvidos na inspeção;

5) Aparelhagem empregada: câmera modelo Nikon D3300 com resolução de 24,2 megapixels, com lentes intercambiáveis, sendo duas lentes, uma de $18 \mathrm{~mm}$ e outra de 55 $\mathrm{mm}$.

6) Local: a Torre está localizada na região mais alto de Sobradinho, Alto Colorado, no setor habitacional, Taquari, Trecho 2, Quadra 200, Conjunto 1 e 2, aproximadamente 20 km do centro de Brasília; 
7) Umidade relativa do ar: variando anualmente entre $40 \%$ e $80 \%$, porém na estação seca ficam muitas vezes abaixo de 30\%, bem abaixo do ideal considerado pela Organização Mundial da Saúde (OMS), de 60\%; No dia e horário da inspeção a umidade relativa do ar era aproximadamente de $32 \%$.

8) Inauguração: Foi inaugurada no dia 21 de abril de 2012, juntamente com o aniversário de 52 anos de Brasília;

9) Função: a Torre tem a função de transmitir sinal de TV digital no Distrito Federal e cidades satélites, além de ser um espaço de visitação, turismo e entretenimentos;

10) Números de níveis: É formada por 14 lajes localizadas no fuste e no cálice; além da laje de cobertura e as lajes de sustentação das cúpulas;

11) Entorno: região rural, com algumas áreas vazia em volta da Torre, mais já existe condomínios residênciais, comércio e previsto construções de mais empreendimento;

12) Sistema construtivo: o sistema construtivo da Torre de concreto é dividido em interno e externa. O sistema interno é formado por pórtico, ou seja, viga e pilares, preenchidos em tijolos e divisórias. Já o sistema externo, é formado por parede circular de concreto armado, chamado de fuste ou pilar parede, além do cálice e braços de sustentação das cúpulas. o sistema construtivo da torre metálica é formato a partir do conjunto de vários segmentos ou tubos mélaticos concnetados por parafusos, sendo $50 \mathrm{~m}$ de estrutura metálica e $12 \mathrm{~m}$ de antena.

\subsection{CLASSIFICAÇÃO DA AGRESSIVIDADE DO AMBIENTE}

A norma ABNT NBR 6118:2014 dispõe sobre os requisitos para a durabilidade, considerando a agressividade do meio ambiente relacionada às ações físicas e químicas que atuam sobre as estruturas de concreto, independente das ações mecânicas, das variações volumétricas de origem térmica, da retração hidráulica e outras previstas no dimensionamento das estruturas de concreto.

As Tabelas 7.1 e 7.2 da norma ABNT NBR 6118:2014, apresenta a classificação da agressividade do ambiente a ser considerada nos projetos de estruturas correntes, podendo ser avaliada simplificadamente, segundo as condições de exposição da estrutura ou de suas partes. Permitindo assim, atribuir o nível de agressividade para os elementos estruturais que compõe a Torre de TV Digital de Brasília. Na Tabela 15 é identificado a classificação da agressividade ambiental do monumento em estudo. 
Tabela 15 - Classificação da agressividade dos ambientes da Torre de TV Digital de Brasília

\begin{tabular}{|l|l|l|l|}
\hline Edifício & $\begin{array}{l}\text { Classe de } \\
\text { agressividade } \\
\text { ambiental }\end{array}$ & Agressividade & $\begin{array}{l}\text { Risco de } \\
\text { deterioração da } \\
\text { estrutura }\end{array}$ \\
\hline $\begin{array}{l}\text { Torre de TV } \\
\text { Digital de Brasília }\end{array}$ & \multicolumn{1}{|c|}{ I } & Rural & Insignificante \\
\hline
\end{tabular}

Com a identificação da classificação da agressividade ambiental, é possível fixar para a Torre as características exigidas para o cobrimento das estruturas de concreto que deverá ser utilizado e espessura mínima do cobrimento a serem adotadas, a fim de garantir uma proteção às armaduras ao longo do tempo e um prolongamento da vida útil do monumento.

Na comparação de valores de resistência a compressão e cobrimento do concreto de acordo com a norma ABNT NBR 6118:2014 versus especificações do projeto, pode-se observar uma compatibilidade na consideração dos parâmetros adotados quanto a classe de agressividade ambiental. Tudo indica que os autores do projeto também consideraram um ambiente do tipo rural, com a classe de agressividade ambiental fraca I, indicando que o risco de deterioração da estrutura é insignificante, admitindo um microclima com classe de agressividade mais branda. Já a resistência do concreto a compressão especificado no projeto apresenta um valor um pouco acima do que especificado na norma, demonstrado segurança da adoção desses parâmetros, como podemos observar na Tabela 16.

Tabela 16 - Qualidade do projeto e cobrimento: Norma ABNT NBR 6118:2014 x Especificações do Projeto

\begin{tabular}{|c|c|c|c|c|c|}
\hline & \multicolumn{3}{|c|}{ ABNT NBR 6118:2014 } & \multicolumn{2}{|c|}{$\begin{array}{c}\text { Especificações do projeto } \\
\text { ABNT NBR 6118:2003 }\end{array}$} \\
\hline & \multicolumn{2}{|c|}{ Qualidade do projeto } & \multirow[b]{2}{*}{ Cobrimento } & \multirow[b]{2}{*}{$\begin{array}{l}\text { Resistência } \\
\text { fck }\end{array}$} & \multirow[b]{2}{*}{ Cobrimento } \\
\hline Elementos & $\begin{array}{l}\text { Relação } \\
\text { a/c }\end{array}$ & $\begin{array}{l}\text { Resistência } \\
\text { fck }\end{array}$ & & & \\
\hline Lajes & \multirow{3}{*}{$\leq 0,65$} & \multirow{3}{*}{$\geq 20 \mathrm{MPa}$} & $20 \mathrm{~mm}$ & \multirow{3}{*}{$\geq 35 \mathrm{MPa}$} & $20 \mathrm{~mm}$ \\
\hline Vigas & & & $25 \mathrm{~mm}$ & & $25 \mathrm{~mm}$ \\
\hline Pilares & & & $25 \mathrm{~mm}$ & & $25 \mathrm{~mm}$ \\
\hline
\end{tabular}




\subsection{METODOLOGIA GDE/UnB PARA QUANTIFICAÇÃO DO GRAU DE DETERIORAÇÃO DA ESTRUTURA DA TORRE DE TV DIGITAL}

\subsubsection{Divisão em famílias de elementos}

Inicialmente, as estruturas de concreto da Torre de TV Digital de Brasília são divididas em famílias de elementos típicos: Pilares; Vigas; Lajes; Cortinas ou Muro arrimo; Escadas; Rampas; Reservatório superior e inferior; Bloco de fundação; Junta de dilatação; Elementos de composição arquitetônica; Braços (hastes de sustentação das cúpulas) e Fuste (pilar parede).

\subsubsection{Fator de ponderação do dano (Fp)}

Como mostra a Tabela 17 os valores são definidos pelo profissional habilitado para realizar a inspeção, de acordo com os problemas mais relevantes quanto aos aspectos de durabilidade e segurança estrutural. Uma determinada manifestação patológica, por exemplo, pode ter fatores de ponderação diferentes de acordo com as características da família onde o elemento se insere, dependendo das consequências que o dano possa acarretar. Demais Tabelas segue no Apêndice A.

Tabela 17 - Famílias de alguns elementos da torre, danos e fatores de ponderação Fonseca (2007)

\begin{tabular}{|l|c|}
\hline \multicolumn{2}{|c|}{ Lajes } \\
\hline Danos & Fp \\
\hline Carbonatação & 3 \\
\hline Cobrimento deficiente & 3 \\
\hline Contaminação por cloretos & 4 \\
\hline Corrosão de armaduras & 5 \\
\hline Desagregação & 3 \\
\hline Desplacamento & 3 \\
\hline Eflorescência & 2 \\
\hline Falhas de concretagem & 2 \\
\hline Fissuras & 2 a $5^{*}$ \\
\hline Manchas & 3 \\
\hline Flechas & 5 \\
\hline Sinais de esmagamento & 4 \\
\hline Umidade & 3 \\
\hline
\end{tabular}

\begin{tabular}{|l|c|}
\hline \multicolumn{2}{|c|}{ Vigas } \\
\hline Danos & Fp \\
\hline Carbonatação & 3 \\
\hline Cobrimento deficiente & 3 \\
\hline Contaminação por cloretos & 4 \\
\hline Corrosão de armaduras & 5 \\
\hline Desagregação & 3 \\
\hline Desplacamento & 3 \\
\hline Eflorescência & 2 \\
\hline Falhas de concretagem & 2 \\
\hline Fissuras & 2 a $5^{*}$ \\
\hline Manchas & 3 \\
\hline Flechas & 5 \\
\hline Sinais de esmagamento & 4 \\
\hline Umidade & 3 \\
\hline
\end{tabular}




\begin{tabular}{|l|c|}
\hline \multicolumn{2}{|c|}{ Pilares } \\
\hline Danos & Fp \\
\hline Carbonatação & 3 \\
\hline Cobrimento deficiente & 3 \\
\hline Contaminação por cloretos & 4 \\
\hline Corrosão de armaduras & 5 \\
\hline Desagregação & 3 \\
\hline Desplacamento & 3 \\
\hline Desvio de geometria & 4 \\
\hline Eflorescência & 2 \\
\hline Falha de concretagem & 3 \\
\hline Fissuras & 2 a $5^{*}$ \\
\hline Manchas & 3 \\
\hline Recalque & 5 \\
\hline Sinais de esmagamento & 5 \\
\hline Umidade na base & 3 \\
\hline
\end{tabular}

\begin{tabular}{|l|c|}
\hline \multicolumn{2}{|c|}{ Fustes } \\
\hline Danos & Fp \\
\hline Carbonatação & 3 \\
\hline Cobrimento deficiente & 3 \\
\hline Contaminação por cloretos & 4 \\
\hline Corrosão de armaduras & 5 \\
\hline Desagregação & 3 \\
\hline Desplacamento & 3 \\
\hline Desvio de geometria & 4 \\
\hline Eflorescência & 2 \\
\hline Falha de concretagem & 3 \\
\hline Fissuras & 2 a $5^{*}$ \\
\hline Manchas & 3 \\
\hline Recalque & 5 \\
\hline Sinais de esmagamento & 5 \\
\hline Umidade na base & 3 \\
\hline
\end{tabular}

\subsubsection{Fator de intensidade do dano (Fi)}

O Fator de Intensidade do Dano (Fi) é atribuído a partir de vistorias, de acordo com a gravidade da manifestação em um elemento. As Figuras 46 mostram a aplicação do fator de intensidade do dano (Fi), para alguns elementos que compõem a estrutura da Torre de TV Digital de Brasília que foram observados a partir da inspeção visual da estrutura e seguindo as instruções do roteiro. Demais Tabelas segue no Apêndice A.
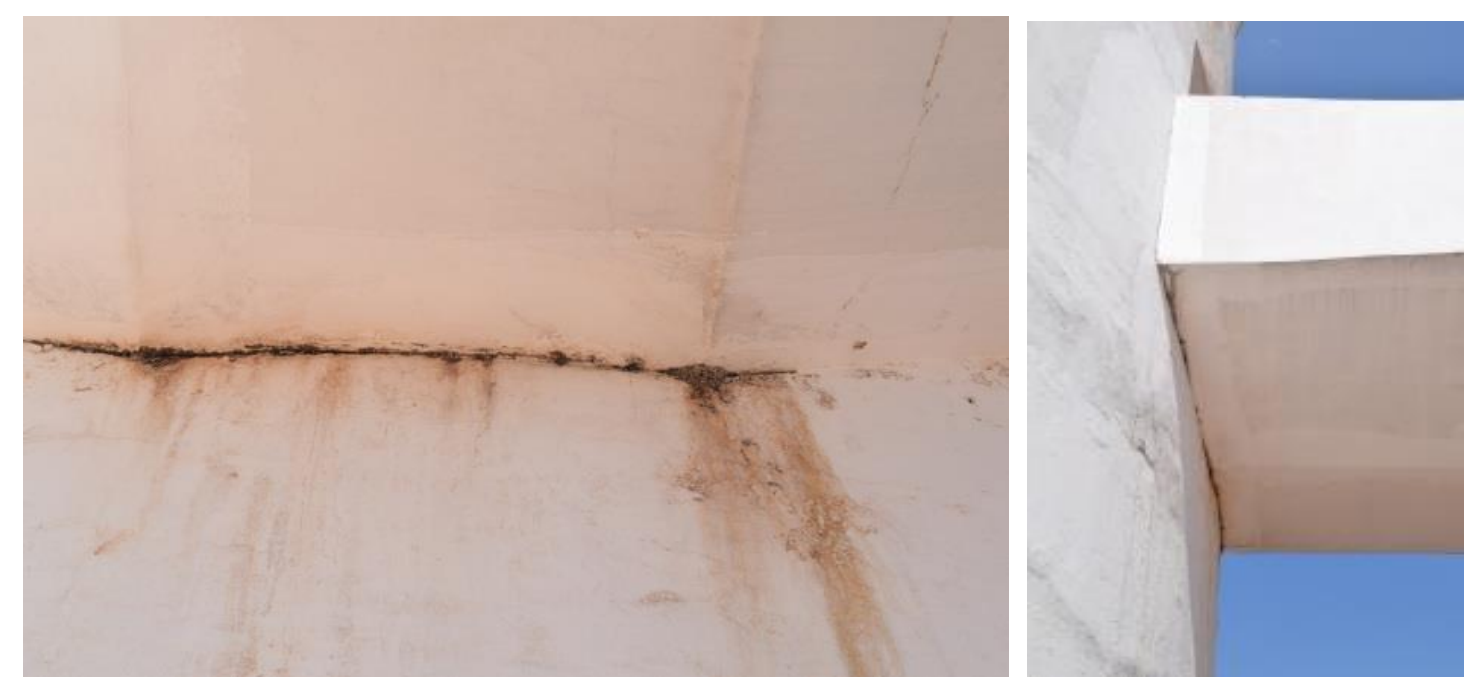

Fuste (pilar parede) - Local: Ligação Rampa Entrada e Fuste

Manchas: $\mathrm{Fi}=3,0$

Umidade: $\mathrm{Fi}=3,0$ 

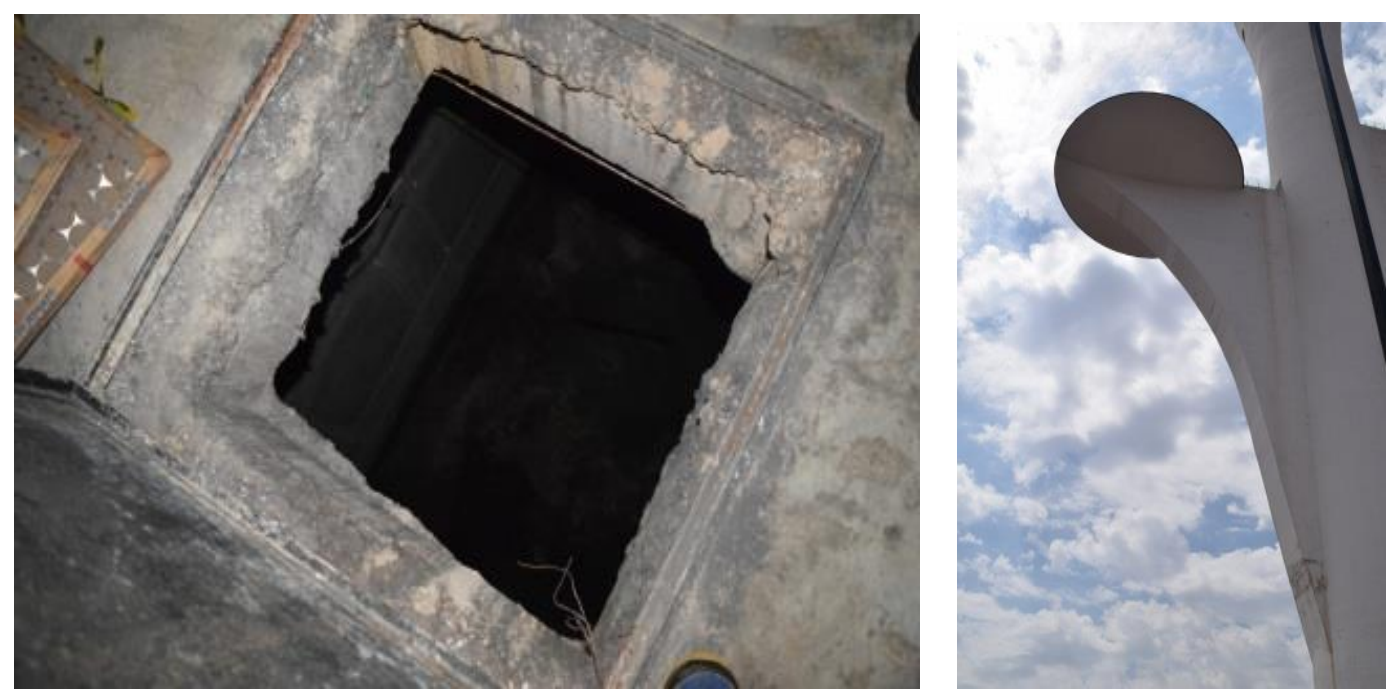

Braços - Local: Ligado ao fuste de concreto

Umidade da base: $\mathrm{Fi}=3,0$

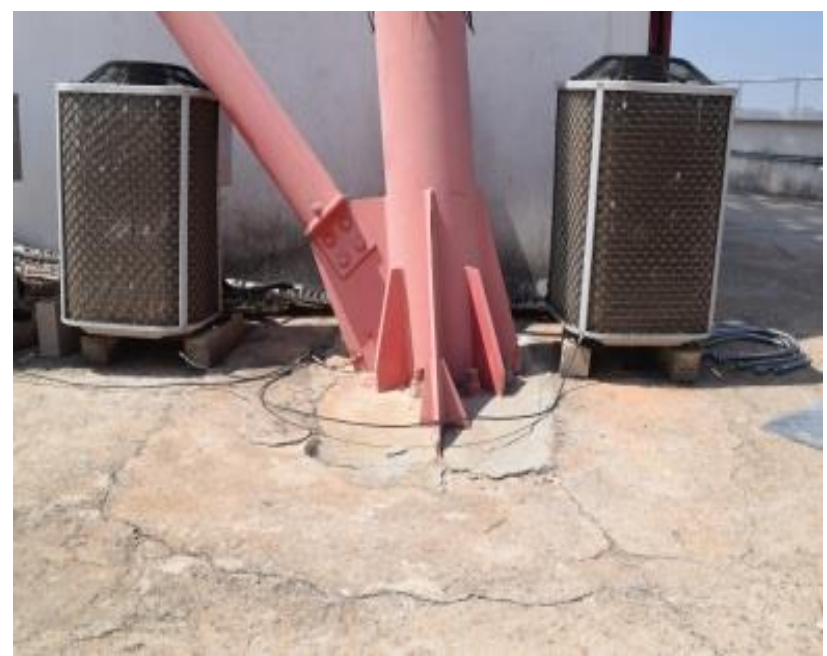

Manchas: $\mathrm{Fi}=2,0$

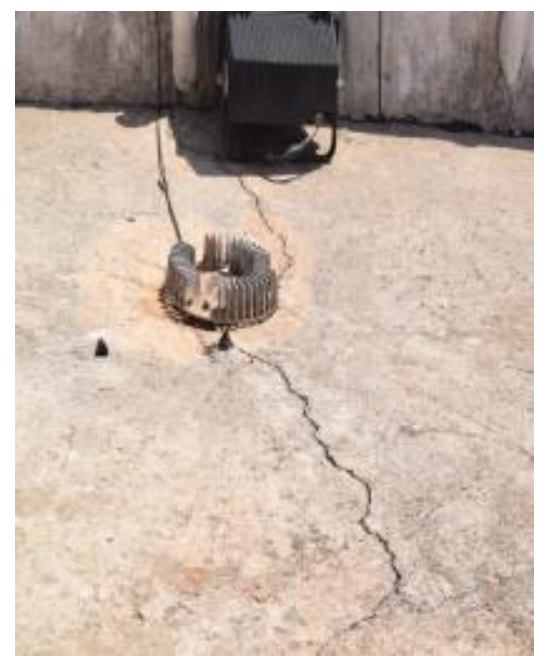

Laje - Local: Cobertura

Falha de concretagem: $\mathrm{Fi}=3,0 \quad$ Fissuras: $\mathrm{Fi}=3,0$

Figuras 46 - Fator de intensidade (Fi) de alguns elementos estruturais da Torre de TV Digital de Brasília

\subsubsection{O Grau (D) de cada dano e Grau de deterioração de um elemento (Gde)}

A fim de facilitar o processo de quantificação e melhor avaliar cada elemento inspecionado da estrutura da Torre, desenvolveu-se uma planilha eletrônica (excel) para automatizar o cálculo do grau de deterioração do dano (D) e do grau de deterioração do elemento (Gde). 
A Tabela 18 mostra os resultados encontrados do grau de dano (D) e a Tabela 19 o grau de deterioração do elemento (Gde), na inspeção realizada para cada família de elemento. A Tabela 20 mostra algumas planilhas e detalhes das inspeções, como fotos e observações. Demais planilhas estão contidas no Apêndice A.

Tabela 18 - Grau do dano (D), dos elementos estruturais vistoriados da Torre de TV Digital

\begin{tabular}{|c|c|c|c|c|c|}
\hline Elementos & \multicolumn{5}{|c|}{ Grau do Dano (D) } \\
\hline Fuste & D1 & D2 & D3 & D4 & D5 \\
\hline Ligação rampa com fuste & 3,2 & 3,2 & 24 & 24 & 0 \\
\hline Fachada & 2,4 & 1,6 & 4,8 & 0 & 0 \\
\hline Parede circular de concreto & 2,4 & 2,4 & 4,8 & 0 & 0 \\
\hline Braços & D1 & D2 & D3 & D4 & D5 \\
\hline Ligado ao fuste & 1,6 & 4,8 & 24 & 0 & 0 \\
\hline Pilares & D1 & D2 & D3 & D4 & D5 \\
\hline Rampa Entrada & 1,6 & 24 & 4,8 & 0 & 0 \\
\hline Interno(Shaft) & 4,8 & 0 & 0 & 0 & 0 \\
\hline Subsolo & 4,8 & 0 & 0 & 0 & 0 \\
\hline Junta de dilatação & D1 & D2 & D3 & D4 & D5 \\
\hline Espelho d'água & 1,6 & 8 & 16 & 0 & 0 \\
\hline Vigas & D1 & D2 & D3 & D4 & D5 \\
\hline Espelho d'água & 4,8 & 16 & 24 & 4,8 & 0 \\
\hline Lajes & D1 & D2 & D3 & D4 & D5 \\
\hline Espelho d'água & 4,8 & 4,8 & 4,8 & 50 & 4,8 \\
\hline Cobertura & 2,4 & 16 & 40 & 0 & 0 \\
\hline Passarela & 2,4 & 2,4 & 0 & 0 & \\
\hline Escada & D1 & D2 & D3 & D4 & D5 \\
\hline Todos pavimentos & 1,6 & 2,4 & 0 & 0 & 0 \\
\hline Rampas & D1 & D2 & D3 & D4 & D5 \\
\hline Rampa monumental & 3,2 & 24 & 4,8 & 0 & 0 \\
\hline Bloco fundação & D1 & D2 & D3 & D4 & D5 \\
\hline Base torre metálica & 2,4 & 24 & 2,4 & 0 & 0 \\
\hline Elemento Arquitetônico & D1 & D2 & D3 & D4 & D5 \\
\hline Lojas e apoio & 2,4 & 0 & 0 & 0 & 0 \\
\hline Cortina (muro arrimo) & D1 & D2 & D3 & D4 & D5 \\
\hline Subsolo & 0 & 0 & 0 & 0 & 0 \\
\hline Reservatórios & D1 & D2 & D3 & D4 & D5 \\
\hline $11^{\circ}$ pavimento & 0 & 0 & 0 & 0 & 0 \\
\hline
\end{tabular}


Tabela 19 - Grau de deterioração do elemento (Gde) dos elementos estruturais vistoriados da Torre de TV Digital de Brasília

\begin{tabular}{|c|c|c|c|}
\hline $\begin{array}{c}\text { Elementos } \\
\text { Estrutururais }\end{array}$ & Gde & $\begin{array}{c}\text { Elementos } \\
\text { Estrutururais }\end{array}$ & Gde \\
\hline $\begin{array}{c}\text { Fuste } \\
\text { Ligação rampa com fuste } \\
\text { Fachada } \\
\text { Parede circular de concreto }\end{array}$ & $\begin{array}{c}37,41 \\
6,98 \\
7,20\end{array}$ & $\begin{array}{c}\text { Escada } \\
\text { Todos pavimentos }\end{array}$ & 3,36 \\
\hline $\begin{array}{c}\text { Braços } \\
\text { Ligado ao fuste }\end{array}$ & 29,05 & $\begin{array}{c}\text { Rampas } \\
\text { Rampa monumental }\end{array}$ & 30,00 \\
\hline $\begin{array}{c}\text { Pilares } \\
\text { Rampa Entrada } \\
\text { Interno(Shaft) } \\
\text { Subsolo }\end{array}$ & $\begin{array}{c}29,05 \\
4,80 \\
4,80\end{array}$ & $\begin{array}{l}\text { Bloco fundação } \\
\text { Base torre metálica }\end{array}$ & 28,00 \\
\hline $\begin{array}{l}\text { Junta de dilatação } \\
\text { Espelho d'água }\end{array}$ & 22,00 & $\begin{array}{c}\text { Elemento Arquitetônico } \\
\text { Lojas e apoio }\end{array}$ & 2,40 \\
\hline $\begin{array}{c}\text { Vigas } \\
\text { Espelho d'água }\end{array}$ & 36,39 & $\begin{array}{c}\text { Cortina (muro arrimo) } \\
\text { subsolo }\end{array}$ & 0,0 \\
\hline $\begin{array}{c}\text { Lajes } \\
\text { Espelho d'água } \\
\text { Cobertura } \\
\text { Passarela }\end{array}$ & $\begin{array}{c}63,87 \\
52,60 \\
3,60\end{array}$ & $\begin{array}{l}\text { Reservatórios } \\
11^{\circ} \text { pavimento }\end{array}$ & 0,0 \\
\hline
\end{tabular}

Tabela 20 - Planilhas e detalhes das inspeções de algumas famílias de elementos estruturais da Torre de TV Digital de Brasília

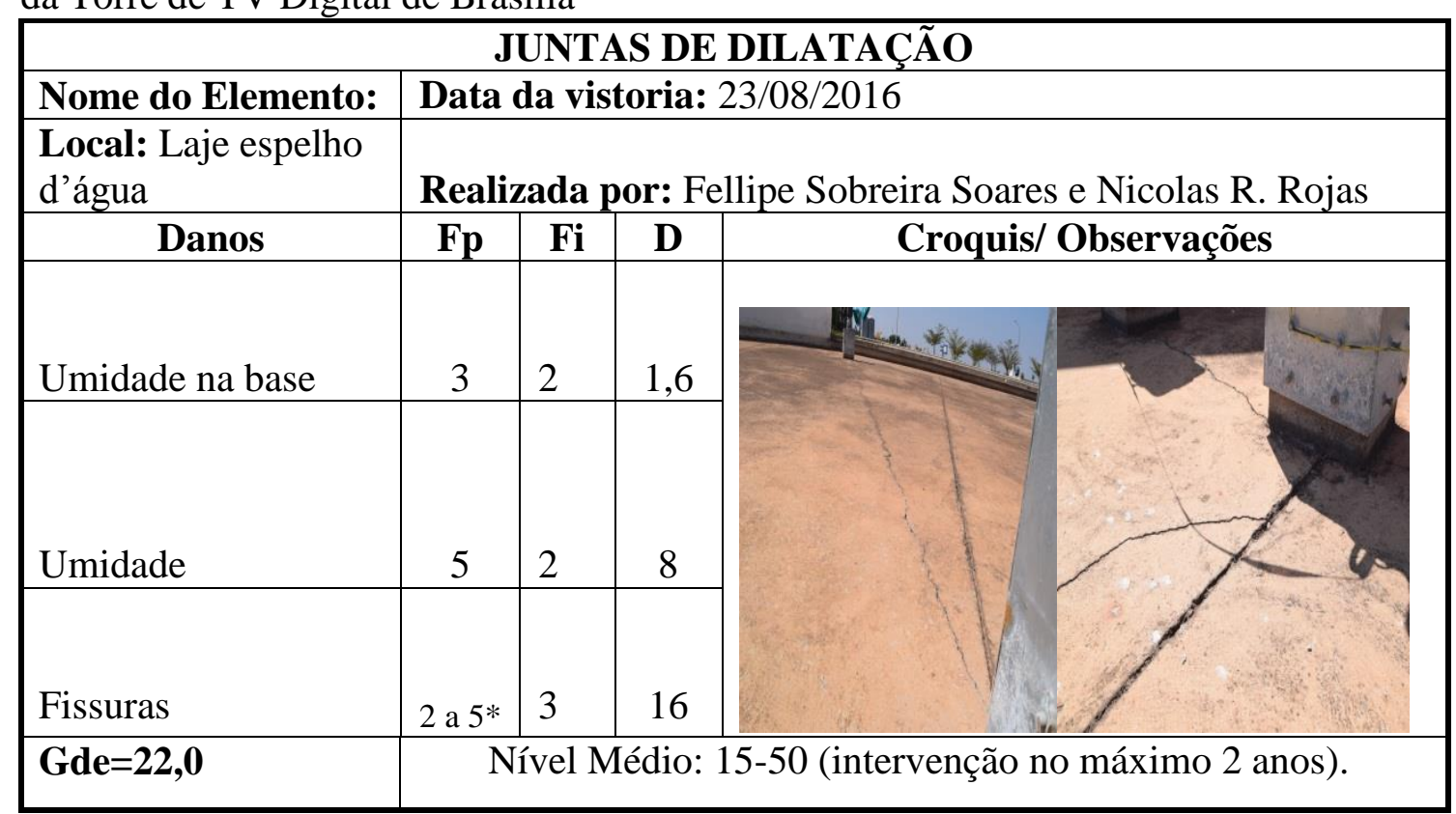




\begin{tabular}{|l|l|l|l|l|}
\hline & \multicolumn{4}{|c|}{ LAJES } \\
$\begin{array}{l}\text { Nome do Elemento: } \\
\text { Lajes }\end{array}$ & \multicolumn{3}{|l|}{ Data da vistoria: 23/08/2016 } \\
\hline Local: Cobertura & \multicolumn{2}{|l|}{ Realizada por: Fellipe Sobreira Soares e Nicolas R. Rojas } \\
\hline Danos & Fp & Fi & D & Croquis/ Observações \\
\hline Carbonatação & 3 & & \\
\hline Cobrimento deficiente & 3 & & \\
\hline $\begin{array}{l}\text { Contaminação por } \\
\text { cloretos }\end{array}$ & 3 & & \\
\hline Corrosão de armaduras & 5 & & \\
\hline Desagregação & 3 & & \\
\hline Desplacamento & 3 & 1 & 2,4 \\
\hline Eflorescência & 2 & & \\
\hline Falhas de concretagem & 2 & 3 & 16 \\
\hline Fissuras & 2 a $5^{*}$ & 3 & 40 \\
\hline Manchas & 3 & & \\
\hline Flechas & 5 & & \\
\hline Sinais de esmagamento & 3 & & \\
\hline Umidade & 3 & & \\
\hline Gde=52,60 & Nível Alto: $50-80$ (intervenção no máximo 1 ano) \\
\hline
\end{tabular}

\begin{tabular}{|c|c|c|c|c|}
\hline \multicolumn{5}{|c|}{ BRAÇOS } \\
\hline $\begin{array}{l}\text { Nome do Elemento: } \\
\text { Braço }\end{array}$ & \multicolumn{4}{|c|}{ Data da vistoria: $23 / 08 / 2016$} \\
\hline Local: ligado ao fuste & \multicolumn{4}{|c|}{ Realizada por: Fellipe Sobreira Soares e Nicolas R. Rojas } \\
\hline Danos & Fp & Fi & D & Croquis/ Observações \\
\hline Carbonatação & 3 & & & \\
\hline Cobrimento deficiente & 3 & & & \\
\hline $\begin{array}{l}\text { Contaminação por } \\
\text { cloretos }\end{array}$ & 4 & & & \\
\hline Corrosão de armaduras & 5 & & & \\
\hline Desagregação & 3 & & & \\
\hline Desplacamento & 3 & & & \\
\hline Desvio de geometria & 4 & & & \\
\hline Eflorescência & 2 & & & \\
\hline Falha de concretagem & 3 & & & \\
\hline Fissuras & 2 a $5 *$ & 1 & 1,6 & \\
\hline Manchas & 3 & 2 & 4,8 & \\
\hline Recalque & 5 & & & \\
\hline Sinais de esmagamento & 5 & & & \\
\hline Umidade na base & 3 & 3 & 24 & \\
\hline Gde $=29,05$ & \multicolumn{4}{|c|}{ Nível Médio: 15-50 (intervenção no máximo 2 anos) } \\
\hline
\end{tabular}




\subsubsection{Grau de deterioração de uma família de elementos (Gdf)}

A Tabela 21 e o gráfico da Figura 47 mostram os resultados do grau de deterioração das famílias de elementos (Gdf) obtidos nos cálculos.

Tabela 21 - Grau de deterioração das famílias de elementos (Gdf) da estrutura da Torre de TV Digital de Brasília

\begin{tabular}{|l|c|}
\hline \multicolumn{1}{|c|}{ Elementos } & Gdf \\
\hline Fuste (pilar parede) & 37,41 \\
\hline Braços & 29,05 \\
\hline Pilares & 29,05 \\
\hline Junta de dilatação & 22,00 \\
\hline Vigas & 36,39 \\
\hline Lajes & 76,96 \\
\hline Escada & 3,36 \\
\hline Rampas & 30,00 \\
\hline Bloco fundação & 28,00 \\
\hline Elemento Arquitetônico & 2,40 \\
\hline Cortina (muro arrimo) & 0,0 \\
\hline Reservatórios & 0,0 \\
\hline
\end{tabular}

Figura 47 - Gráfico representativo do grau de deterioração das famílias (Gdf) de elementos da estrutura da Torre de TV Digital de Brasília

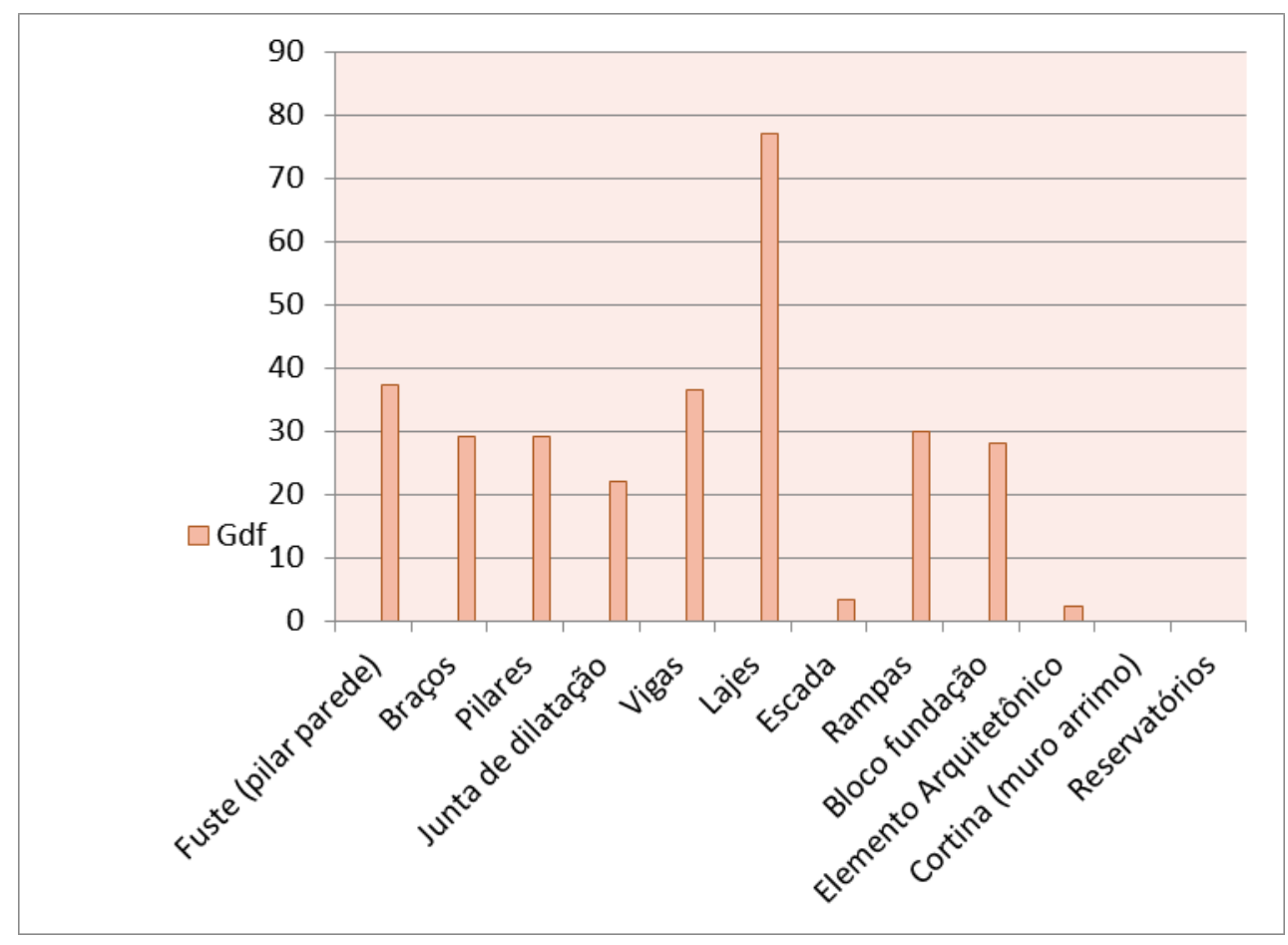


Diante dos resultados pode-se tirar algumas conclusões preliminares. Por exemplo, o grau de deterioração da família das lajes foi o mais alto, como se observa na Figura 47, principalmente pelos danos encontrados na laje de cobertura e laje do espelho d'água, como fissuras e falhas de concretagem, apresentando um nível alto de deterioração (50-80) e indicando assim, intervenções em no máximo um ano para esses elementos estruturais.

De forma geral, o grau de deterioração das familias dos elementos estruturais, apresentaram um nível de deterioração médio (15-50) se dá devido a presença de alguns danos, como pequenas fissuras, manchas, desplacamento, degradação e presença de umidade. No entanto, esses sinais de deterioração não compromete a estabilidade global do edificio ou a segurança dos usuários.

Não foram encontrados manisfetações patológicas nas cortinas e reservatórios superiores, para que se pudesse quantificar, pois os mesmos estão em perfeito estado. As escadas e alguns elementos arquitetônicos apresentaram um grau de deterioração muito pequeno, quase insignificante, com apenas poucas manifestações localizadas.

\subsubsection{Grau de deterioração da estrutura (Gd) e o Fator de relevância estrutural (Fr)}

Assim, adotando os fatores de relevância (Fr) para cada família de elementos da estrutura da Torre, é possível aplicar a formulação matemática e se obter o grau de deterioração da estrutura (Gd), conforme apresentado na Tabela 22.

Tabela 22 - Determinação do grau de deterioração da estrutura (Gd) da Torre de TV Digital de Brasília

\begin{tabular}{|c|c|c|c|c|}
\hline Elementos & Gdf & Fr & Fr*Gdf & Gd \\
\hline Fuste (pilar parede) & 37,41 & 3 & 112,24 & \\
\hline Braços & 29,05 & 3 & 87,16 & \\
\hline Pilares & 29,05 & 5 & 145,26 & \\
\hline Junta de dilatação & 22,00 & 3 & 66,00 & \\
\hline Vigas & 36,39 & 5 & 181,94 & \\
\hline Lajes & 76,96 & 4 & 307,82 & \\
\hline Escada & - & 3 & - & \\
\hline Rampas & 30,00 & 3 & 90,00 & \\
\hline Bloco fundação & 28,00 & 4 & 112,00 & \\
\hline Elemento Arquitetônico & - & 1 & - & \\
\hline Cortina (muro arrimo) & - & 3 & - & \\
\hline Reservatórios & - & 2 & - & \\
\hline$\sum=$ & & 39 & $1.102,42$ & 28,27 \\
\hline \multicolumn{5}{|c|}{$\begin{array}{l}\text { Nível de deterioração da estrutura: Médio (15-50) } \\
\text { Ações a serem adotadas: Definir prazo/ natureza para nova inspeção. } \\
\text { Planejar intervenção em longo prazo (máx. } 2 \text { anos). }\end{array}$} \\
\hline
\end{tabular}


Como podemos observar o grau de deterioração da estrutura $(\mathrm{Gd})$ da Torre de TV Digital de Brasília é igual a 28,27 de acordo com os cálculos efetuados.

A Tabela 23 mostra que o nível de deterioração da estrutura pode ser classificado em cinco níveis de deterioração, as quais indicam as condições físicas atuais do edifício, as ações a serem adotadas e os prazos máximos para se planejar as devidas manutenções.

Tabela 23 - Classificação dos níveis de deterioração da estrutura - Fonseca (2007)

\begin{tabular}{|c|c|l|}
\hline $\begin{array}{c}\text { Nível de } \\
\text { deterioração }\end{array}$ & Gd & \multicolumn{1}{c|}{ Ações a serem adotadas } \\
\hline Baixo & $0-15$ & Estado aceitável. Manutenção preventiva. \\
\hline Médio & $\mathbf{1 5}-\mathbf{5 0}$ & $\begin{array}{l}\text { Definir prazo/ natureza para nova inspeção. } \\
\text { Planejar intervenção em longo prazo (máx. 2 anos). }\end{array}$ \\
\hline Alto & $50-80$ & $\begin{array}{l}\text { Definir prazo/ natureza para inspeção especializada detalhada. } \\
\text { Planejar intervenção em médio prazo (máx. 1 ano). }\end{array}$ \\
\hline Sofrível & $80-100$ & $\begin{array}{l}\text { Definir prazo/ natureza para inspeção especializada detalhada. } \\
\text { Planejar intervenção em curto prazo (máx. 6 meses). }\end{array}$ \\
\hline Crítico & $>100$ & Inspeção especial emergencial. Planejar intervenção Imediata. \\
\hline
\end{tabular}

De acordo com os resultados obtidos por meio da utilização da metodologia GDE/UnB, para quantificação do dano na estrutura de concreto, a Torre apresenta um grau de deterioração de nível médio (Gd: 15-50), sugerindo-se realizar intervenções em no máximo dois anos, para que se possa restabelecer sua condição ideal, e dispor ao monumento, segurança, estética e funcionalidade.

Como os resultados obtidos não indica um nível crítico, ou seja, sem a necessidade de uma inspeção emergencial ou não havendo necessidade de maiores investigações, optando-se assim pela a não realização de ensaios, exceto à laje de cobertura e à laje do espelho d'água, por apresentarem um nível alto de deterioração devem ser investigadas minuciosamente.

Os parâmetros especificados nos projetos foram suficientes para caracterizar as propriedades dos materiais e diagnosticar as causas dos fenômenos progressivos nos elementos estruturais. No entanto, se esses pequenos danos encontrados não forem combatidos, pode ocorrer o aumento da deterioração e requerer maiores investigações e maiores gastos para resolução do problema. 


\subsection{DISCUSSÃO DOS RESULTADOS}

Com a aplicação da metodologia GDE/UnB para quantificar o grau de deterioração da estrutura da Torre, pôde-se obter um nível de deterioração da estrutura igual à Gd = 28,27, sendo médio (Gd: 15-50) e alertando para a necessidade de traçar um planejamento de intervenções em no máximo dois anos. Esses resultados são considerados coerentes e reflete a real situação física de parte do monumento.

No entanto, percebeu-se que algumas famílias de elementos estruturais apresentaram valores maiores que o nível global da estrutura, porém continuam no mesmo nível de deterioração, exceto a família das lajes.

A famílias das lajes apresentou $\mathrm{Gdf}=76,96$, indicando um nível de deterioração sendo alto (Gd:50-80), alertando para a necessidade de realizar intervenções em no máximo um ano. Esse alto nível de deterioração se deu principalmente devido ao estado em que se encontra a laje do espelho d'água que estava vazio, sem dúvidas pela falta de impermeabilização desse "reservatório aberto" e pode-se observar inúmeras fissuras, e algumas dessas são excessivas que se prolongam em toda a sua borda.

As bases do sistema de iluminação que fica localizado no espelho d'água apresenta uma fissuração contínua em volta de todo o fuste. A falta de impermeabilização é evidente no espelho, as placas de concreto estão fissuradas e falta junta de dilatação.

Alguns danos na laje de cobertura também contribuíram para que houvesse essa deterioração um pouco mais elevada que o grau de deterioração da estrutura $(\mathrm{Gd})$, pois essa laje encontra-se mal acabada e existem inúmeras fissuras que se propagam por todo o elemento. Além disso, existem pequenas lascas de concreto, uma espécie de desplacamento do concreto.

O aparecimento dessas fissuras na laje de cobertura deve ter como causa a movimentação térmica e não ser nociva. No entanto, como se trata do um monumento do patrimônio de Brasília, seu acompanhamento torna-se obrigatório e deve ser reparadas por razões estéticas, pois sua visão é desagradável aos usuários. Vale ressaltar que essas manifestações patológicas não afetam a estabilidade global da estrutura da Torre.

Portanto, as fissuras da laje de cobertura merecem acompanhamento, mesmo que sejam apenas na capa do revestimento da impermeabilização. É necessária uma investigação mais minuciosa nos locais onde essas fissuras se apresentarem mais acentuadas. 
A família dos elementos vigas apresentou $\mathrm{Gdf}=36,39$, esse fato se deu pela consideração da borda do espelho d'água como sendo elemento viga, que se encontra em um estado de deterioração preocupante, com presença de fissuras excessivas em partes deste elemento.

Outra família que também superou o grau de deterioração da estrutura, foram os elementos braços $\mathrm{Gdf}=37,41$, apresentando manchas, pequenas fissuras e sinais de umidade devido infiltrações que chegaram a acumular água nesse elemento. Esse fato se deu por que no acesso ou passarelas para as cúpulas existem pequenas calhas que não foram suficientes para suportar a vazão da água, devido isso, meses atrás ocorreu infiltrações, que chegaram a acumular água dentro da estrutura de concreto. Recentemente foi retirada essa água e feitos reparos nos sistemas de calhas, mas ficou visíveis os danos causados, com a presença de umidade, manchas e pequenas fissuras.

O grau de deterioração das famílias dos elementos fustes e rampa monumental, são Gfd $=37,41$ e Gdf $=30,00$, respectivamente, sendo observados nesses elementos pequenas fissuras e manchas. Na ligação da rampa com o fuste de concreto existe presença de fissuração, além de manchas amareladas, esverdeados e brancos, se assemelhando a eflorescência, e umidade nessa ligação. Já na rampa monumental foram observadas pequenas fissuras verticais com o mesmo espaçamento ao longo de toda a rampa. As fissuras se assemelham as fissuras devido à flexão em vigas. Também foram visualizadas manchas amareladas, principalmente devido o contato com a água e presença de umidade.

Vale ressaltar que em todo o fuste da torre existe pequenas fissuras e algumas manchas escuras e amareladas. Essas manchas e fissuras são de cunho estético, na qual, toda a fachada externa da Torre apresenta a necessidade de refazer a pintura. Pode se observar também um mau acabamento do fuste, e são visíveis os "traços" das fôrmas da concretagem.

Para a família de elemento do bloco de fundação $\mathrm{Gdf}=28,00$, esse bloco trata-se da base da torre metálica, onde é feito sua fixação nas vigas de uma laje inferior a laje de cobertura. Essa fixação envolve as duas lajes, e é exatamente nesse encontro entre a laje e a torre metálica que apresenta fissuração, e observa-se a falta de um reforço maior, mesmo já sendo bem ancorada.

O grau de deterioração da família dos elementos pilares $\mathrm{Gdf}=29,05$, foi devido à presença de manchas e umidade dos pilares de sustentação da rampa monumental de acesso à torre e por falta de acabamento ou reboco em alguns pórticos do subsolo e shafts. Em nenhum dos casos há comprometimento da estabilidade ou segurança da estrutura da Torre. 
A falta de impermeabilização e falta de junta de dilatação nas lajes que compõem o espelho d'água que resultou para a família dos elementos de junta de dilatação um grau de $\mathrm{Gdf}=22,00$, nos quais de observa a presença de fissuras e umidade, fato que acabou impedindo o funcionamento desse espelho.

Vale a pena ressaltar outras observações em relação à vistoria realizada na estrutura da Torre. Por exemplo, as cúpulas aos $60 \mathrm{~m}$ e aos $80 \mathrm{~m}$ de altura (exposições, bar e café) nunca teve seu funcionamento normal, principalmente devido problemas no sistema de esgoto a vácuo, além da falta de impermeabilização do piso e do carpete em uma das cúpulas.

Nas passarelas de acesso as cúpulas, observa-se um sistema de captação de águas pluviais inadequado, onde as calhas pluviais adotadas não estão apropriadas para a descida da água. Existindo apenas pequenas aberturas de vazão da água, que por serem insuficientes acabaram ocasionando infiltrações que provocaram pequenas manchas e umidade nos braços de sustentação das cúpulas.

O subsolo da Torre serve como central de máquinas e conta com 8 boxes de apoio para as emissoras, de onde saem cabos de transmissão de sinal digital por shaft até o topo da torre, onde há a falta de forro em alguns ambientes. É nesse espaço que fica a casa de bomba, casa splits e pluviais que estão em perfeito estado de funcionamento, porém o sistema de esgoto a vácuo encontra-se com problemas e acabou afetando o funcionamento do monumento. A Torre conta ainda, com um sistema de captação da água da chuva e reaproveita essa água acumulada.

Os pavimentos tipos conta com 3 elevadores com capacidade de $900 \mathrm{~kg}$ ou 12 pessoas na parte interna dos pavimentos e estão com os acabamentos em perfeito estado, com ambiente limpo, branco e sem manchas, além de lajes e paredes em ótimo estado de conservação.

O mirante, à 110 m de altura está com os acabamentos em perfeito estado, limpo, branco e sem manchas, com lajes e paredes em ótimo estado de conservação.

As escadas de forma geral estão com as paredes em ótimo estado, porém falta revestimento no piso.

A casa de máquina onde fica localizado o motor do elevador (carga concentrada), encontra-se no $14^{\circ}$ pavimento, e conta com um sistema de ancoragem para movimentar esse motor, demonstrando uma segurança nesse sistema. 
Os reservatórios superiores estão localizados no $11^{\circ}$ pavimento, dispondo de duas caixas d'agua, e o ambiente encontra-se em perfeito estado.

Pode-se notar que a metodologia GDE/UnB pode determinar a necessidade de inspeção e ensaios emergenciais e até reparos ou reforços imediatos em elementos específicos, mesmo que o grau de deterioração a estrutura como um todo seja médio ou baixo. 


\section{MODELAGEM ESTRUTURAL}

\subsection{INTRODUÇÃO}

A modelagem tridimensional e a análise estrutural permitem fazer uma simulação do comportamento da estrutura, ou seja, uma previsão de como a estrutura responde as combinações de ações atuantes.

Essa análise estrutural pode ser feita através da utilização de modelos físicos, matemáticos e computacionais. No entanto, devido às diversas teorias de análise existente e dependendo da representação do modelo estrutural adotado, podem levar a resultados bem diferentes da situação real.

Devido essa distorção de resultados, é necessário associar os modelos matemáticos e computacionais para se garantir uma confiabilidade de uma análise estrutural, e principalmente do conhecimento técnico e científico dos profissionais envolvidos, para fazer a correta interpretação do problema.

Com o intuito de realizar uma avaliação estrutural na Torre de TV Digital é feita uma modelagem tridimensional no programa computacional SAP2000, para avaliar o seu desempenho estrutural e verificar a sua segurança. Essas verificações devem atender ao Estado Limite de Serviço (ELS) e Estado Limite Último (ELU) da estrutura de acordo com as normas técnicas brasileiras.

\subsection{PROCEDIMENTO ADOTADO}

\subsubsection{Modelagem no SAP 2000 e discretização da estrutura}

A modelagem tridimensional no programa SAP2000 foi feita a partir dos projetos arquitetônicos e estruturais adquiridos na NOVACAP, que disponibilizou todas as plantas baixas, cortes, fachadas, plantas estruturais, armadura e outros projetos referentes à obra.

O programa computacional SAP2000 é um software de modelagem em elementos finitos, utilizado para realizar a análise tridimensional estática e para o dimensionamento de estruturas. O Método dos Elementos Finitos (MEF) é caracterizado pela discretização ou decomposição da estrutura em malha, dividindo o modelo em um número finito de partes ou elementos conectados entre si, por nós. 
O software contém uma interface gráfica interativa para a criação de modelos em barra (frame), casca (shell), sólido (solid) e elemento de ligação. Os elementos frame são utilizados para modelar vigas, pilares, treliças ou elemento de ligação, definindo a sua seção transversal e as propriedades do material. Já os Shell e Solid são para modelar lajes, paredes, cascas, membranas e bloco de fundação.

A geometria da Torre de TV Digital de Brasília foi desenvolvida a partir de uma malha cartesiana ( grid), definida pelas coordenadas de diâmetro e altura do edifício. Todo o modelo tridimensional foi discretizado em malha quadrada de aproximadamente $50 \mathrm{~cm} \mathrm{x}$ $50 \mathrm{~cm}$ (fustes) e malha poligonal formada a partir de um ângulo de $5^{\circ}$ e $9^{\circ}$ (bloco de fundação, bases das cúpulas e lajes), exceto nos braços da torre que sustentam as cúpulas, onde surgem formatos variados, especialmente nas regiões de transições de malhas.

O bloco de fundação com $25 \mathrm{~m}$ de diâmetro e 4,5 m de altura, foi modelado em elemento sólido de 8 nós (solid) e, colocados vínculos de $2^{\circ}$ gênero no apoio, distribuídos de forma radial em relação ao eixo central da torre.

Já o fuste da base com $12 \mathrm{~m}$ de diâmetro, e de $50 \mathrm{~cm}, 40 \mathrm{~cm}$ e $30 \mathrm{~cm}$ de espessura, foi modelado em elemento de casca (shell). O cálice também modelado em elemento de casca (shell), tem diâmetro variado entre $12 \mathrm{~m}$ e $20 \mathrm{~m}$, com espessuras também variando de $30 \mathrm{~cm}, 35 \mathrm{~cm}, 45 \mathrm{~cm}, 55 \mathrm{~cm}$ e $65 \mathrm{~cm}$.

Os braços ou hastes que sustentam as cúpulas, com $25 \mathrm{~cm}$ de espessura, também modelado em elemento de casca (shell). As vigas, pilares e estrutura metálica da antena foram modelados em elemento de barra (frame), com seção transversal e suas propriedades definidas de acordo com o projeto estrutural. A Tabela 24 e a Tabela 25 mostram os elementos estruturais, dimensões, material e modelos utilizados para a modelagem da Torre de TV Digital de Brasília.

Tabela 24 - Modelagem Sap2000: Estrutura de Aço

\begin{tabular}{|c|c|c|c|}
\hline \multicolumn{3}{|c|}{ Torre Metálica - Elementos de Barras (Frame) } \\
\hline Elemento $(\mathbf{m m})$ & Material & Tipo & $\begin{array}{c}\text { Dimensões (mm) } \\
\text { Diâmeto(Ø);espessura (t) }\end{array}$ \\
\hline Tubo D73x7,0 & VMB-250 & Tubo Circular & 73,0 e 7,0 \\
\hline Tubo D101x5,7 & VMB-250 & Tubo Circular & 101 e 5,7 \\
\hline Tubo D168x7,1 & VMB-250 & Tubo Circular & 168 e 7,1 \\
\hline Tubo D141,3x9,5 & VMB-250 & Tubo Circular & 141,3 e 9,5 \\
\hline Tubo D88x5,5 & VMB-250 & Tubo Circular & 88 e 5,5 \\
\hline Tubo D168x11 & VMB-250 & Tubo Circular & 168 e 11 \\
\hline Tubo D219x82 & VMB-250 & Tubo Circular & 219 e 82 \\
\hline
\end{tabular}


Tabela 25 - Modelagem Sap2000: Estrutura de Concreto

\begin{tabular}{|c|c|c|c|}
\hline \multicolumn{4}{|c|}{ Fundação da Torre - Elementos Sólido (Solid) } \\
\hline Elemento & Material & Tipo & Espessura (m) \\
\hline Bloco Enchimento & Material $\gamma=18 \mathrm{KN} / \mathrm{m}^{3}$ & Solid & 3,0 \\
\hline Bloco Fundação & Concreto C25/E24,15 & Solid & 4,5 \\
\hline \multicolumn{4}{|c|}{ Torre de Concreto - Elementos de Placas (Shell) } \\
\hline Elemento & $\begin{array}{c}\text { Material } \\
\text { fck(MPa) / E(GPa) }\end{array}$ & Tipo & Espessura (m) \\
\hline Fuste 30 & Concreto C50/E35 & Shell-Thin & 0,30 \\
\hline Fuste 40 & Concreto C50/E35 & Shell-Thin & 0,40 \\
\hline Fuste 50 & Concreto C50/E35 & Shell-Thin & 0,50 \\
\hline Cálice 35 & Concreto C50/E35 & Shell-Thin & 0,35 \\
\hline Cálice 45 & Concreto C50/E35 & Shell-Thin & 0,45 \\
\hline Cálice 55 & Concreto C50/E35 & Shell-Thin & 0,55 \\
\hline Cálice 65 & Concreto C50/E35 & Shell-Thin & 0,65 \\
\hline Base Cúpula & Concreto C35/E35 & Shell-Thin & 0,25 \\
\hline Braço Haste & Concreto C35/E35 & Shell-Thin & 0,25 \\
\hline Laje Cobertura & Concreto C35/E35 & Shell-Thin & 0,25 \\
\hline Outras Lajes & Concreto C35/E35 & Shell-Thin & 0,15 \\
\hline \multicolumn{4}{|c|}{ Elementos Estruturais - Elementos de Barras (Frame) } \\
\hline Elemento & $\begin{array}{c}\text { Material } \\
\text { fck(MPa)/E(GPa) }\end{array}$ & Tipo & Dimensões (m) \\
\hline Pilar 01 & Concreto C35/E30 & Quadrado & $0,20 \times 0,20$ \\
\hline Pilar 02 & Concreto C35/E30 & Retangular & $0,20 \times 0,40$ \\
\hline Pilar 03 & Concreto C35/E30 & Formato "T" & $\begin{array}{c}\mathrm{h}=0,85 \\
\mathrm{bw}=0,60 ; \mathrm{t}=0,25\end{array}$ \\
\hline Viga 01 & Concreto C35/E30 & Retangular & $1,00 \times 0,25$ \\
\hline Viga 02 & Concreto C35/E30 & Retangular & $0,70 \times 0,25$ \\
\hline Viga 03 & Concreto C35/E30 & Retangular & $0,50 \times 0,25$ \\
\hline
\end{tabular}

Portanto, o objetivo da modelagem tridimensional (Figura 48) feita no programa computacional SAP2000, é avaliar o desempenho estrutural e verificar a segurança da Torre. Essas verificações devem atender aos estados limites: Estado Limite de Serviço (ELS) e Estado Limite Último (ELU) da estrutura de acordo com as normas técnicas brasileiras. 

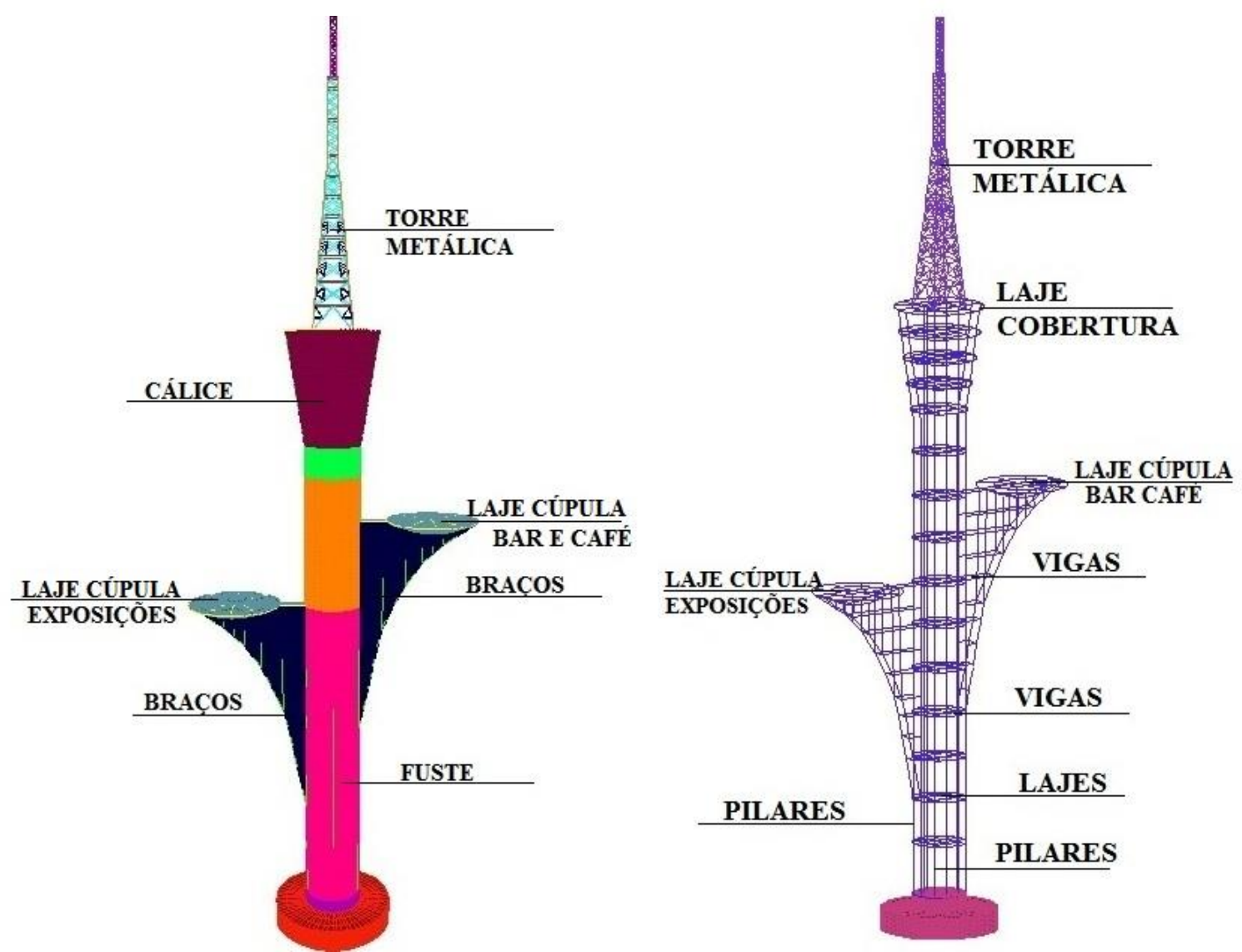

Figura 48 - Modelo tridimensional a ser analisado - (SAP2000)

\subsubsection{Carregamentos}

O peso próprio da estrutura é gerado automaticamente pelo o SAP2000, sendo o peso específico do concreto armado de $25 \mathrm{kN} / \mathrm{m}^{3}$. Já as cargas permanentes e sobrecargas foram adotadas conforme especificados no artigo científico Bessa et al. (2013) sobre a Torre de TV Digital de Brasília, argumentando está conforme o indicado no projeto arquitetônico de Oscar Niemeyer. Onde as cargas permanentes são de $1,5 \mathrm{kN} / \mathrm{m}^{2}$ para piso mais o revestimento e $1,0 \mathrm{kN} / \mathrm{m}^{2}$ para as divisórias, e as sobrecargas de $5 \mathrm{kN} / \mathrm{m}^{2}$ para as galerias de artes e exposição, como mostra a Tabela 26.

Tabela 26 - Carregamento adotada na estrutura da Torre de TV Digital de Brasília

\begin{tabular}{|c|c|}
\hline \multicolumn{2}{|c|}{ Carregamentos } \\
\hline Permanentes Diretas $(G)$ & Variáveis Diretas $(\mathbf{Q})$ \\
\hline Peso Próprio $-\mathrm{Pp}\left(25 \mathrm{KN} / \mathrm{m}^{3}\right)$ & Cúpula 01 - Q $\left(5,0 \mathrm{KN} / \mathrm{m}^{2}\right)$ \\
\hline Piso + Revestimento $-\mathrm{G}\left(1,5 \mathrm{KN} / \mathrm{m}^{2}\right)$ & Cúpula 02-Q $\left(5,0 \mathrm{KN} / \mathrm{m}^{2}\right)$ \\
\hline Divisórias $-\mathrm{G}\left(1,0 \mathrm{KN} / \mathrm{m}^{2}\right)$ & Vento $(\mathrm{Y}) 90^{\circ} \mathrm{e}(\mathrm{X}) 0^{\circ}-\mathrm{V} 1 \mathrm{e} \mathrm{V} 2$ \\
\hline
\end{tabular}


Os efeitos da ação do vento $\left(90^{\circ}\right.$ e 0 ) foram determinados a partir de aproximações obtidas na norma ABNT NBR 6123:1988 (Apêndice C), onde foram encontradas as forças, a partir da velocidade característica da região, dos coeficientes de arrasto, pressão dinâmica e área de contato, sendo fornecido os seguintes parâmetros:

- Velocidade básica: Vo=35m/s (Brasília-DF);

- Velocidade Caracteristica: Vk= Vo S1 S2 S3 (m/s);

- Fator do terreno: $\mathrm{S} 1=1,0$ (terreno plano, vegetação rasteira);

- Categoria de rugosidade: S2=II (categoria II, classe C, altura de $120 \mathrm{~m}$ );

- Fator estatístico: $\mathrm{S} 3=1,10$ (centro de comunicação);

- Presão dinâmica: $\mathrm{q}=0,613 \mathrm{Vk}^{2}(\mathrm{~N} / \mathrm{m})$;

- Coeficiente de arrasto: $\mathrm{Ca}=1,10$ para a direção x $\left(0^{\circ}\right)$ considerando o formato cilíndrico com as dimensões $(\emptyset=12 \mathrm{~m}$ e $\mathrm{h}=120 \mathrm{~m})$ e $\mathrm{Ca}=1,42$ para a direção y $\left(90^{\circ}\right)$ considerando um formato retangular com as dimensões ( $63,0 \mathrm{~m} \times 12,0 \mathrm{~m}$ e $\mathrm{h}=1,20 \mathrm{~m})$;

- Força do vento resultante: $\mathrm{Fa}=\mathrm{Ca}^{*} \mathrm{q}^{*} \mathrm{~A}(\mathrm{KN})$.
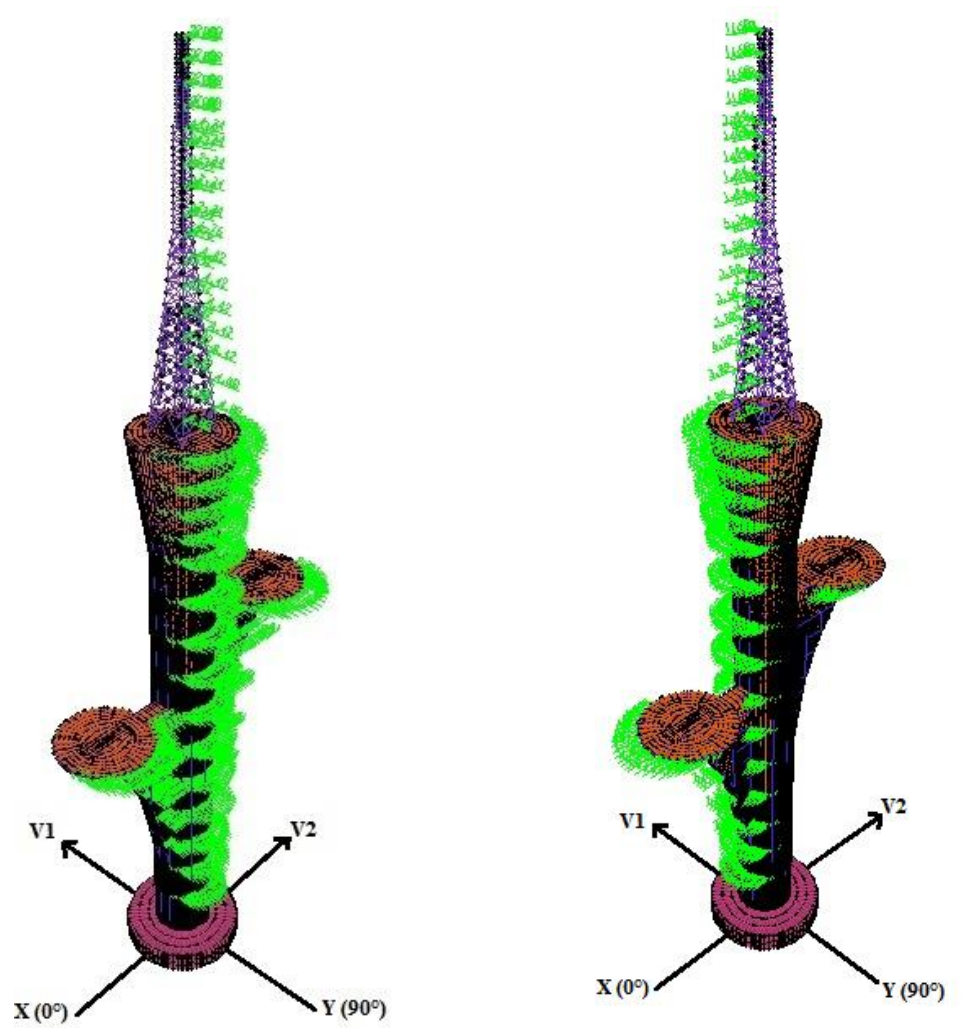

Figura 49 - Forças horizontais devido à ação do vento $90^{\circ}$ e $0^{\circ}$ - (SAP2000) 
Os valores obtidos das forças do vento resultante para cada altura da Torre, foram aplicados ou distribuídos nos nós de cada pórtico espacial proporcionalmente à sua área de influência. A representação da atuação dessas forças devido à ação do vento pode ser observada na Figura 49, onde mostra a aplicação das ações nas duas direções: Vento (Y) $90^{\circ}$ e $(\mathrm{X}) 0^{\circ}-\mathrm{V} 1$ e V2, respetivamente.

\subsubsection{Combinações de Ações: ELU e ELS}

O acontecimento simultâneo do conjunto de ações sobre o edifício é muito pequeno. Portanto, faz-se necessário analisar a estrutura sobre umas combinações de cargas de diferentes origens.

Existem dois grupos de combinações a serem verificadas: combinações últimas - ELU (se refere à resistência da estrutura, dimensionamento dos elementos estruturais, a favor da segurança.); e combinações serviços - ELS (se refere a avaliação do funcionamento da estrutura, verificações de flechas, fissuração e vibração da estrutura).

As combinações ELU e ELS da Torre de TV Digital de Brasília, estão conforme a Tabela 27 e a Tabela 28, respectivamente.O Apêndice B demonstra os procedimentos dos cálculos para as combinações de ações do monumento.

Tabela 27 - Combinações de ações: Estado Limite Ultimo (ELU)

\begin{tabular}{|c|c|}
\hline \multicolumn{2}{|c|}{ Combinações de ações: Estado Limite Ultimo - ELU } \\
\hline \multicolumn{2}{|c|}{ ELU: Combinações ultimas normais } \\
\hline$F d=\mathrm{Yg} * \mathrm{Fgk}+\mathrm{Y} \varepsilon \mathrm{g} * \mathrm{~F} \varepsilon \mathrm{gk}+\mathrm{Yq} *\left(\mathrm{Fq} \mathrm{k}+\sum_{j=2}^{n} \psi o j * F q j k\right)+Y \varepsilon g * \psi o \varepsilon * F \varepsilon q k$ \\
\hline \multicolumn{2}{|c|}{ Combinações com carga variável direta principal (carga de vento) } \\
\hline ELU 01 & ELU 01: Fd=1,4 ( Pp+G) + 1,4 V1 + 0,98 Q (desfavorável) \\
\hline ELU 02 & ELU 02: $\mathrm{Fd}=1,4(\mathrm{Pp}+\mathrm{G})+1,4 \mathrm{~V} 2+0,98 \mathrm{Q}$ \\
\hline \multicolumn{2}{|c|}{ Combinações com carga variável direta principal (carga de uso). } \\
\hline ELU 03 & ELU 03: $\mathrm{Fd}=1,4(\mathrm{Pp}+\mathrm{G})+1,4 \mathrm{Q}+0,84 \mathrm{~V} 1$ \\
\hline ELU 04 & ELU 04: $\mathrm{Fd}=1,4(\mathrm{Pp}+\mathrm{G})+1,4 \mathrm{Q}+0,84 \mathrm{~V} 2$ \\
\hline
\end{tabular}


Tabela 28 - Combinações de ações: Estado Limite de Serviço (ELS)

\section{Combinações de ações: Estado Limite de Serviço -ELS}

ELS: Combinações quase permanentes $(\mathrm{CQP})=\mathrm{Fd}$, ser $=\sum_{\mathrm{j}=1}^{\mathrm{n}} F g j k+\sum_{j=1}^{n} \psi 2 j * F q j k$

Combinações com carga variável direta principal (carga de vento e carga de uso)

ELS 01 $\quad$ ELS 01: Fd, ser $=(\mathrm{Pp}+\mathrm{G})+0,0 \mathrm{~V}+0,4 \mathrm{Q}$;

Combinações frequentes $(\mathrm{CF})=\mathrm{Fd}$, ser $=\sum_{\mathrm{j}=1} F g j k+\psi 1 * F q 1 k+\sum_{j=2} \psi 2 j * F q j k$

Combinações com carga variável direta principal (carga de vento)

\begin{tabular}{l|l} 
ELS 02 & ELS 02: Fd,ser $=(\mathrm{Pp}+\mathrm{G})+0,3 \mathrm{~V} 1+0,4 \mathrm{Q}($ desfavorável $)$
\end{tabular}

\begin{tabular}{l|l} 
ELS 03 & ELS 03: Fd,ser $=(P p+G)+0,3$ V2 + 0,4 Q
\end{tabular}

Combinações com carga variável direta principal (carga de uso).

ELS 04 $\quad$ ELS 04: Fd,ser $=(\mathrm{Pp}+\mathrm{G})+0,6 \mathrm{Q}+0,0 \mathrm{~V}$ (desfavorável)

\subsection{PARÂMETROS ADOTADOS PARA A ESTRUTURA DE CONCRETO: NORMA ABNT NBR 6118:2014}

$\mathrm{Na}$ análise linear, para determinação de esforços solicitantes e verificação de estados limites de serviço, deve-se utilizar o módulo de elasticidade secante-Ecs, cujo valor é cerca de $85 \%$ do módulo de elasticidade tangente inicial-Eci, correspondente à inclinação do início da curva tensão versus deformação. A análise linear é geralmente empregada na verificação dos ELS, sendo utilizada para ELU somente em situações que se possa garantir a ductilidade dos elementos estruturais.

Os materiais e as suas propriedades foram adotados de acordo com o especificado no projeto estrutural. O concreto do bloco de fundação tem uma resistência a compressão de fck =25 MPa. Já o concreto das paredes, lajes e vigas, tem uma resistência a compressão de fck =35 MPa, mais adição de 7\% de sílica ativa. O concreto das paredes externas da Torre tem uma resistência a compressão de fck $=50 \mathrm{MPa}$, mais adição de $8 \%$ de sílica ativa. $\mathrm{O}$ módulo de elasticidade para superestrutura de Ec $=30 \mathrm{GPa}$ e para as paredes externas de Ec=35 GPa. Na Tabela 29 são detalhados os cálculos dos parâmetros adotados para a estrutura de concreto armado da Torre de TV Digital de Brasília. 
Tabela 29 - Parâmetros adotados para a estrutura de concreto da Torre de TV Digital

\begin{tabular}{|c|c|c|c|c|c|c|}
\hline \multicolumn{7}{|c|}{ Parâmetros adotados } \\
\hline Elementos & fck (Mpa) & Eci(GPa) & Ecs(GPa) & Gc(GPa) & $\boldsymbol{\sigma c}(\mathbf{M P a})$ & $\boldsymbol{f c t , \boldsymbol { m } ( \mathbf { M P a } )}$ \\
\hline $\begin{array}{c}\text { Bloco de } \\
\text { fundação }\end{array}$ & 25 & 28 & 24,15 & 10,063 & 15,20 & 2,57 \\
\hline $\begin{array}{c}\text { Paredes, } \\
\text { lajes, vigas }\end{array}$ & 35 & 33,13 & 29,403 & 12,252 & 21,3 & 3,21 \\
\hline $\begin{array}{c}\text { Paredes } \\
\text { externas }\end{array}$ & 50 & 39,60 & 36,63 & 15,262 & 30,4 & 4,072 \\
\hline
\end{tabular}

\subsection{RESULTADOS DA MODELAGEM}

Através da modelagem tridimensional no programa computacional SAP2000 e análise estrutural, pode se obter os deslocamentos horizontais e verticais máximos, deformação máxima e esforços máximos, a partir das combinações últimas e de serviços mais desfavoráveis, e comparar valores com a prescrição da norma ABNT NBR 6118:2014.

\subsubsection{Verificações Estado Limite de Serviço: ELS}

A Tabela 30 mostra a verificação dos deslocamentos horizontais e verticais, e a Tabela 31 da rotação máxima para o estado limite de serviço, respectivamente. Onde a rotação, os deslocamentos verticais e horizontais encontrados estão de acordo com a norma brasileira de concreto armado, dando condições de utilização da Torre aos usuários, demostrando um bom desempenho.

Tabela 30 - Verificação dos deslocamentos horizontais máximo (ação do vento) e verticais:

$$
\text { ELS (ABNT NBR 6118:2014 x SAP2000) }
$$

\begin{tabular}{|c|c|c|c|c|c|}
\hline \multicolumn{6}{|c|}{$\begin{array}{l}\text { Deslocamento horizontal da Torre TV Digital de Brasília } \\
\text { (Ação do vento - ABNT NBR 6123:1988) }\end{array}$} \\
\hline \multicolumn{6}{|c|}{ ELS 02: Fd, ser = ( Pp+G)+ 0,30V1+ 0,4Q (Desfavorável) } \\
\hline \multirow[b]{2}{*}{ Elemento } & \multirow[b]{2}{*}{$\begin{array}{l}\text { Elevação } \\
(\mathbf{m})\end{array}$} & \multirow{2}{*}{$\begin{array}{c}\text { (SAP2000) } \\
\begin{array}{c}\delta \mathrm{U} 1=\text { Direção } X \\
(\mathrm{~cm})\end{array}\end{array}$} & \multicolumn{2}{|c|}{ (ABNT NBR 6118:2014) } & \multirow[b]{2}{*}{$\begin{array}{r}\text { SU1 X } \\
\text { Svento }\end{array}$} \\
\hline & & & $\begin{array}{c}\text { Svento= } \\
\text { H/1700(cm) }\end{array}$ & $\begin{array}{c}\delta \mathrm{H}=\mathrm{H} / 500 \\
(\mathrm{~cm})\end{array}$ & \\
\hline Fuste & 61,0 & 1,06 & 3,58 & 12,2 & 0,3 \\
\hline Cúpula & 61,0 & 1,06 & 3,58 & 12,2 & 0,3 \\
\hline Fuste & 79,5 & 1,92 & 4,68 & 15,9 & 0,41 \\
\hline Cúpula & 79,5 & 1,98 & 4,68 & 15,9 & 0,42 \\
\hline Cobertura & 120,0 & 3,90 & 7,05 & 24,0 & 0,55 \\
\hline Antena & 182,0 & 10,73 & 10,70 & 36,4 & 1,0 \\
\hline
\end{tabular}




\begin{tabular}{|c|c|c|c|c|c|}
\hline \multicolumn{6}{|c|}{$\begin{array}{c}\text { Deslocamento vertical da Torre TV Digital de Brasília } \\
\text { (Flechas - ABNT NBR 6118:2014) }\end{array}$} \\
\hline \multicolumn{6}{|c|}{ ELS 04: Fd, ser $=(P p+G)+0,60 Q+0,0 V 2$ (Desfavorável) } \\
\hline \multirow[t]{2}{*}{ Elemento } & \multirow{2}{*}{$\begin{array}{c}\text { Elevação } \\
\text { (m) }\end{array}$} & \multirow{2}{*}{$\begin{array}{c}\text { Vão } \\
\text { teórico } \\
\text { (m) }\end{array}$} & (SAP2000) & (NBR 6118:2014) & \multirow[b]{2}{*}{ 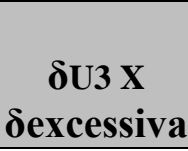 } \\
\hline & & & $\begin{aligned} \delta U 3= & \text { DireçãoZ } \\
& (\mathrm{cm})\end{aligned}$ & $\begin{array}{c}\delta \text { excessiva }=\mathrm{L} / 250 \\
(\mathrm{~cm})\end{array}$ & \\
\hline Laje 01 & 5,0 & 12,0 & $-0,33$ & 4,80 & 0,07 \\
\hline Laje 02 & 14,5 & 12,0 & $-0,50$ & 4,80 & 0,10 \\
\hline Laje 03 & 23,5 & 12,0 & $-0,68$ & 4,80 & 0,14 \\
\hline Laje 04 & 33,0 & 12,0 & $-0,82$ & 4,80 & 0,17 \\
\hline Laje 05 & 42,5 & 12,0 & $-1,0$ & 4,80 & 0,21 \\
\hline Laje 06 & 52,0 & 12,0 & $-1,12$ & 4,80 & 0,23 \\
\hline Laje 07 & 61,0 & 12,0 & $-1,22$ & 4,80 & 0,25 \\
\hline Cúpula 01 & 61,0 & 25,0 & $-6,51$ & 10,0 & 0,65 \\
\hline Laje 08 & 70,5 & 12,0 & $-1,32$ & 4,80 & 0,28 \\
\hline Laje 09 & 79,5 & 12,0 & $-1,42$ & 4,80 & 0,30 \\
\hline Cúpula 02 & 79,5 & 25,0 & $-7,82$ & 10,0 & 0,78 \\
\hline Laje 10 & 89,0 & 12,0 & $-1,53$ & 4,80 & 0,32 \\
\hline Laje 11 & 98,0 & 13,8 & $-1,61$ & 5,52 & 0,30 \\
\hline Laje 12 & 103,5 & 14,8 & $-1,60$ & 5,92 & 0,27 \\
\hline Laje 13 & 109,0 & 15,8 & $-1,62$ & 6,32 & 0,26 \\
\hline Laje 14 & 114,5 & 17,8 & $-1,60$ & 7,12 & 0,23 \\
\hline Cobertura & 120,0 & 20,0 & $-1,54$ & 8,0 & 0,20 \\
\hline
\end{tabular}

Tabela 31 - Verificação da rotação máxima: ELS 02 (ABNT NBR 6118:2014 x SAP2000)

\begin{tabular}{|c|c|c|c|}
\hline \multirow{3}{*}{$\begin{array}{c}\text { Elevação } \\
(\mathbf{m})\end{array}$} & Rotação máxima: (ABNT NBR 6118:2014 x SAP2000) \\
\cline { 2 - 3 } & Rotação $($ rad) & $\begin{array}{c}\text { ABNT NBR } \\
\text { 6118:2014 }\end{array}$ & Rotação $($ rad) \\
\hline 120,0 & 0,00048 & 0,0017 & 0,28 \\
\hline 182,0 & 0,00165 & 0,0017 & 0,97 \\
\hline
\end{tabular}

Observa-se nas lajes de sustentação da cúpula 01(exposição) e cúpula 02 (bar café) que houve deslocamentos verticais (flechas) expressivas, sendo de $6,51 \mathrm{~cm} \mathrm{e} \mathrm{7,82} \mathrm{cm,}$ respectivamente. No entanto, estão de acordo com a norma, já que nessas lajes admite-se um deslocamento vertical de $10,0 \mathrm{~cm}$. Os engenheiros envolvidos optaram-se por utilizar contra flechas na execução dos braços laterais que sustentam as cúpulas, onde no nível superior de cada braço foi feito uma protensão, exatamente onde estão os tabuleiros que formam as estruturas da cúpula, responsável por absorver as cargas dos consoles.

A Tabela 32 mostra a verificação das tensões nas estruturas de concreto da Torre, onde as tensões atuantes de cálculo devem ser menores ou iguais as tensões resistentes de cálculo (бatuante $\leq$ olimite). A fim de aumentar o fator de segurança e confiabilidade da análise estrutural, foi feito a majoração das cargas e redução das resistências dos materiais. 
Tabela 32 - Tensões atuante na estrtura da Torre de TV Digital de Brasília

\begin{tabular}{|c|c|c|c|c|c|}
\hline \multicolumn{6}{|c|}{ Tensões Torre de TV Digital de Brasília } \\
\hline \multicolumn{6}{|c|}{ ELS 02: Fd, ser=( Pp+G)+ 0,30V1+ 0,40Q (desfavorável) } \\
\hline Elemento & $\begin{array}{c}\text { fck } \\
(\mathrm{MPa})\end{array}$ & $\begin{array}{l}\text { бatuante } \\
\text { (MPa) }\end{array}$ & $\begin{array}{c}\text { Olimite } \\
\text { (MPa) }\end{array}$ & $\begin{array}{c}f c t, m(a t) \\
(\mathrm{MPa})\end{array}$ & $\begin{array}{c}f c t, m(\lim ) \\
(\mathrm{MPa})\end{array}$ \\
\hline Fuste & 50 & $-1,50$ & $-30,4$ & - & 4,07 \\
\hline Laje Cobertura & 35 & $-3,50$ & $-21,3$ & - & 3,21 \\
\hline Laje Cúpula 01 & 35 & $-4,50$ & $-21,3$ & 10,0 & 3,21 \\
\hline Laje Cúpula 02 & 35 & $-6,50$ & $-21,3$ & 13,0 & 3,21 \\
\hline Fundação & 25 & - & - & - & 2,57 \\
\hline \multicolumn{6}{|c|}{$\begin{array}{l}\text { Observações: Na ligação, ou no encontro laje e fuste (pilar parede), há uma redução das } \\
\text { tensões de compressão. De forma geral toda a torre apresenta tensões de compressões } \\
\text { com baixa deformabilidade. Com Variação de tensões máxima de compressão de }-11,84 \\
\text { MPa e tensões máxima de tração de }+23,64 \mathrm{MPa} \text {. }\end{array}$} \\
\hline
\end{tabular}

Foi realizada a análise linear elástica da estrutura utilizando o programa computacional SAP2000, e o deslocamento horizontal máximo no topo da torre de concreto foi de 3,90 $\mathrm{cm}$ e no topo da antena metálica teve um valor igual a $10,73 \mathrm{~cm}$, com rotação máxima igual 0,00165 rad. De acordo com a norma ABNT NBR 6118:2014, item 13.3, o deslocamento horizontal máximo e a rotação máxima devem atender as seguintes prescrições: H/500 e $\Theta$ igual a $0.0017 \mathrm{rad}$. E o deslocamento limite para verificação em serviço no estado de deformação excessivas da estrutura é de (L/250).

Portanto, a Torre atende quanto aos deslocamentos máximos horizontais e verticais de acordo com a norma vigente. Pode-se notar também que as tensões atuantes na Torre são baixas em relação a resistência de compressão limite do concreto e as tensões atuantes de tração são absorvidas pelas armaduras especificadas.

\subsubsection{Verificações Estado Limite último: ELU}

$\mathrm{Na}$ verificação da segurança, os esforços solicitantes de cálculo devem ser menor ou igual aos esforços resistentes de cálculo $(\mathrm{Sd} \leq \mathrm{Rd})$. A fim de aumentar o fator de segurança e confiabilidade da análise estrutural, foi feito a majoração das cargas ( $\operatorname{Sd}=\mathrm{Sk} \times \gamma \mathrm{f})$ e redução das resistências dos materiais $(\mathrm{Rd}=\mathrm{Rk} / \gamma \mathrm{m})$, onde geralmente esses coeficientes são de $\gamma \mathrm{m}=\gamma \mathrm{s}=1,4$ para o concreto e $\gamma \mathrm{m}=\gamma \mathrm{c}=1,15$ para o aço.

A Tabela 33 mostra os esforços máximos obtidos no software SAP2000 na base da estrutura da Torre (fuste $50 \mathrm{~cm}$ ) para as combinações de ações últimas mais desfavoráveis. Observa-se que o fuste ou pilar parede foi dividido sem setores, onde cada setor varia os esforços normal (Nd) e Momento fletor (Md1) de acordo com a variação do ângulo, como mostra a Figura 50. 
Tabela 33 - Esforços máximos na base do fuste de $50 \mathrm{~cm}$ (SAP2000): ELU 01

\begin{tabular}{|c|c|c|c|}
\hline \multicolumn{4}{|c|}{ Esforços na base do fuste 50 cm - SAP2000 } \\
\hline $\begin{array}{c}\text { Combinações } \\
\text { de Ações }\end{array}$ & $\begin{array}{c}\text { Setor } \\
\text { (ângulo) }\end{array}$ & $\begin{array}{c}\text { Nd } \\
\text { (KN) }\end{array}$ & $\begin{array}{c}\text { Md1 } \\
\text { (KN.m) }\end{array}$ \\
\hline ELU 01 & $0^{\circ}$ a $45^{\circ}$ & $-5144,0$ & $-492,0$ \\
\hline ELU 01 & $45^{\circ}$ a $90^{\circ}$ & $-6738,0$ & $-682,0$ \\
\hline ELU 01 & $90^{\circ}$ a $135^{\circ}$ & $-6747,0$ & $-684,0$ \\
\hline ELU 01 & $135^{\circ}$ a $180^{\circ}$ & $-5167,0$ & $-494,0$ \\
\hline
\end{tabular}

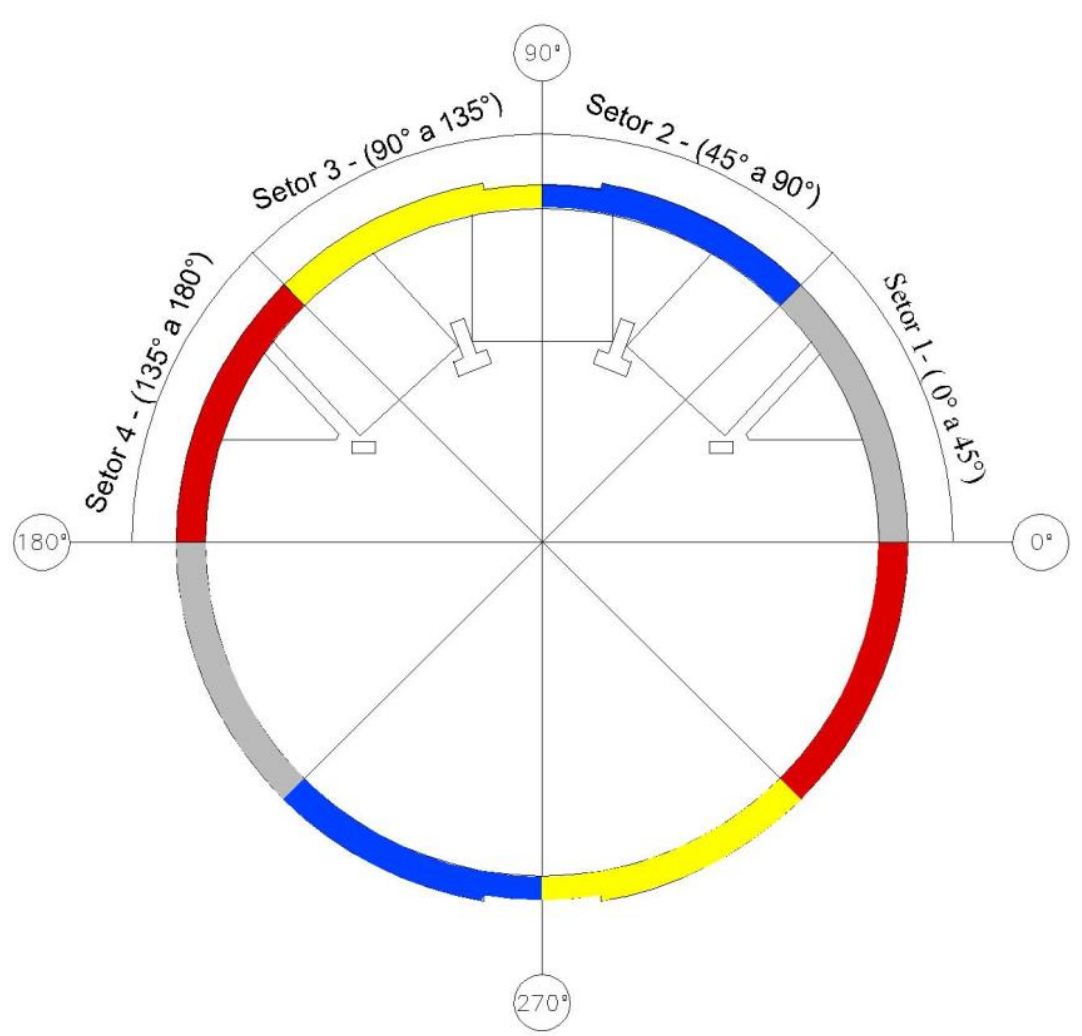

Figura 50 - Divisão do fuste (pilar parede) em setores para obtenção dos esforços máximo na seção analisada - AutoCAD 2D

\subsubsection{Consideração do efeito de segunda ordem em barras esbeltas}

De acordo com a norma ABNT NBR 6118:2014, nos pilares-parede simples ou compostos, onde a esbeltes de cada lâmina que o constitui for menor que 90, pode ser adotado o procedimento aproximado descrito a seguir para levar em conta os efeitos localizados de segunda ordem. O processo é descrito para um pilar-parede simples. $\mathrm{O}$ efeito localizado de segunda ordem deve ser considerado através da decomposição do pilar parede em faixas verticais, de largura ai, que devem ser analisadas como pilares isolados. A largura de cada faixa é dada pela equação (11), onde $t$ é a espessura da parede.

$a i=3 t \leq 100 \mathrm{~cm}$ 
Na Figura 51, o pilar-parede está submetida ao esforço normal $N d$, ao momento fletor de primeira ordem M1xd segundo a direção de maior rigidez, e ao momento de primeira ordem $m 1 d$, distribuído ao longo do comprimento $b$. O momento $M 1 x d$ é decorrente das forças horizontais atuantes no pilar. $\mathrm{O}$ momento distribuído $m 1 d$ considera a imperfeição geométrica para a flexão segundo a direção de menor rigidez.

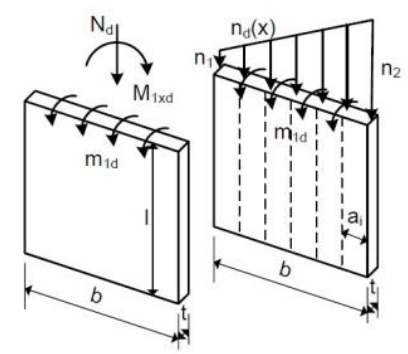

Figura 51 - Divisão do pilar-parede em faixas verticais - ABNT NBR 6118:2014

No entanto, reconhecendo que o esforço normal é maior em um bordo do pilar-parede, é de se supor que os efeitos de segunda ordem também sejam maiores nesse bordo. Para considerar essas variações, o pilar-parede é dividido nas faixas verticais de largura ai. Em cada faixa devem ser aplicados o esforço normal $N d i$ e o momento fletor M1di, conforme é indicado na Figura 52 para faixa do bordo mais solicitado.

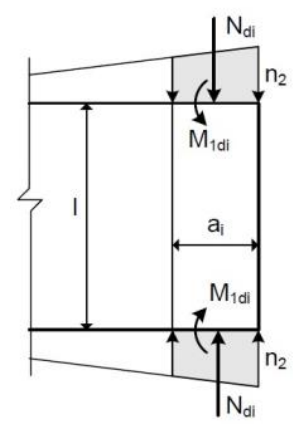

Figura 52 - Esforços para o dimensionamento da faixa do bordo mais solicitado - ABNT NBR 6118:2014

O esforço normal $N d i$ é a resultante de $n d(x)$, que atua na faixa. O momento fletor $M 1 d i$ é dado pela equação (12):

$M 1 d i=$ ai $m 1 d$

Após definir os esforços de primeira ordem $N d i$ e $M 1 d i$, é feita a análise da faixa como se a mesma fosse um pilar isolado de seção retangular com largura ai e altura $t$.

Para incluir os efeitos de segunda ordem em cada faixa isolada do pilar-parede, pode-se empregar qualquer um dos métodos apresentados na norma ABNT NBR 6118:2014 ou em 
outras normas técnicas de projeto, como a norma Americana (ACI). Em todos os casos, considera-se a não-linearidade geométrica (efeitos de segunda ordem) e a não-linearidade física, decorrente do comportamento não-linear do concreto armado.

Entretanto, para evitar a introdução de erros decorrentes do método aproximado para a inclusão da não-linearidade física, será considerado que o pilar é elástico linear. Desse modo, apenas os efeitos de segunda ordem localizados serão analisados. A Figura 53 demostra um pilar bi-rotulado, com altura $l$, submetido à força normal $N d i$ e ao momento de primeira ordem M1di.

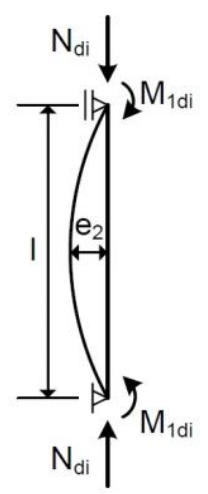

Figura 53 - Pilar bi-rotulado - ABNT NBR 6118:2014

O momento total na seção central do pilar, na configuração deformada da barra, é dado pela equação (13), onde $e 2$ é a excentricidade de segunda ordem.

$$
M d=M 1 d i+N d i e 2
$$

Segundo MacGregor e Wight (2009) essa expressão também pode ser expressa pela equação (14), onde $\beta$ é o fator de amplificação de momentos.

$M d=\beta M 1 d i$

Se o material é elástico linear, o fator de amplificação ( $\beta$ ) ou majoração dos momentos pode ser encontrado pelas seguintes equações 15 e 16, onde $P e i$ é a carga de flambagem do pilar.

$\beta=\frac{1}{\cos \psi}$

$\psi=\frac{\pi}{2} \sqrt{\frac{N d i}{P e i}}$

Pelas equações 17 e 18 encontram-se a carga de flambagem do pilar $\left(P_{e i}\right)$ e a rigidez à 
flexão do elemento (D), respectivamente. Considera-se a faixa de largura $a i$ e espessura $t$, levando em conta o coeficiente de Poisson do material (v), o módulo de elasticidade do material (módulo secante do concreto- $E_{c s}$ ) e o comprimento de flambagem (le).

$$
\begin{aligned}
& P e i=\frac{\pi^{2} D}{l e^{2}} \\
& D=\frac{\text { Ecsait }{ }^{3}}{12\left(1-v^{2}\right)}
\end{aligned}
$$

Araújo (2007) argumenta que a expressão simplificada (equação 19) muito utilizada nas normas de projeto e que fornece bons resultados quando a carga Ndi é pequena em relação à carga de flambagem $(\mathrm{Pei})$.

$$
\beta=\frac{1}{1-\frac{N d i}{P e i}}
$$

Para esse trabalho, o esforço normal atuante na seção transversal do pilar é pequeno em relação à carga de flambagem que é cerca de seis vezes maior. Portanto, pelas equações (14) e (19) pode-se encontrar os esforços majorados atuante na base do fuste de $50 \mathrm{~cm}$, onde são levados em consideração os efeitos de segunda ordem de forma aproximada,

\begin{tabular}{|c|c|c|c|c|c|}
\hline & & \multicolumn{3}{|c|}{ Momento } & Normal \\
\hline $\begin{array}{l}\text { Combinações } \\
\text { de Ações }\end{array}$ & $\begin{array}{c}\text { Seção } \\
\text { (ângulo) }\end{array}$ & $\beta$ & $\begin{array}{c}\text { Md1 } \\
\text { (KN.m) }\end{array}$ & $\begin{array}{c}\text { Md2 = }=\text { Md1 } \\
\text { (KN.m) }\end{array}$ & $\mathrm{Nd}(\mathrm{KN})$ \\
\hline ELU 01 & $0^{\circ}$ a $45^{\circ}$ & 1,133 & $-492,0$ & $-558,0$ & $-5144,0$ \\
\hline ELU 01 & $45^{\circ}$ a $90^{\circ}$ & 1,182 & $-682,0$ & $-807,0$ & $-6738,0$ \\
\hline ELU 01 & $90^{\circ}$ a $135^{\circ}$ & 1,182 & $-684,0$ & $-809,0$ & $-6747,0$ \\
\hline ELU 01 & $135^{\circ}$ a $180^{\circ}$ & 1,34 & $-494,0$ & $-662,0$ & $-5167,0$ \\
\hline
\end{tabular}
como mostra a Tabela 34 .

Tabela 34 - Esforços Nd e Md2 majorados na base do fuste de $50 \mathrm{~cm}$

Já a Tabela 35 demonstra a verificação do dimensionamento desse fuste de $50 \mathrm{~cm}$ no estado limite último (ELU), comparando a armadura especificada no projeto original (Figura 54) com o aço encontrado no dimensionamento. Considerando esse elemento estrutural com seção transversal do tipo pilar parede, onde nesse pilar está sujeito a uma flexão composta, com atuação conjunta do esforço normal $(\mathrm{Nd})$ e momento fletor máximo $(\mathrm{Md} 2)$. 
Tabela 35 - Verificação do dimensionamento do fuste de $50 \mathrm{~cm}$ : ELU 01

\begin{tabular}{|c|c|l|l|c|}
\hline \multicolumn{5}{|c|}{ Dimensionamento x projeto original } \\
\hline Seção análise $(\mathbf{m})$ & $\begin{array}{c}\text { Nd } \\
(\mathbf{k N})\end{array}$ & $\begin{array}{l}\text { Md2 } \\
(\mathbf{K N} . m)\end{array}$ & Dimensionamento & $\begin{array}{c}\text { Projeto original } \\
\text { Aço }(\mathbf{2} \text { faces })(\mathbf{c m})\end{array}$ \\
\hline S1:(1,0x0,50) & $-5144,0$ & $-558,0$ & $10 \varnothing 16.0$ & $10 \varnothing 16.0$ c.20,2 \\
\hline S2:(1,0x0,50) & $-6738,0$ & $-807,0$ & $10 \varnothing 20.0$ & $19 \varnothing 20.0$ c. 10,5 \\
\hline S3:(1,0x0,50) & $-6747,0$ & $-809,0$ & $10 \varnothing 20.0$ & $10 \varnothing 25.0$ c. 20,2 \\
\hline S4:(1,0x0,50) & $-5167,0$ & $-662,0$ & $10 \varnothing 16.0$ & $10 \varnothing 16.0$ c.20,2 \\
\hline
\end{tabular}

A verificação do dimensionamento estrutural do pilar parede com espessura de $50 \mathrm{~cm}$ foi feita a partir da obtenção dos valores dos esforços normais e momentos fletores de cálculo para armaduras das faces do primeiro trecho do fuste, no qual as áreas de aço do pilar parede foram confrontadas com as armaduras apresentadas nas pranchas de detalhamento presente nos projetos de estruturas. Com isso as armaduras especificadas no projeto estrutural atende às necessidades de armadura obtidas na pesquisa.

Pode-se observar no dimensionamento da seção S2, que houve uma diferença expressiva de $10 \emptyset 20$ para 19 Ø 20, nas abordagens do projeto de José Carlos Sussekind e do modelo adotado. Essa diferença pode ser explicada pela não consideração da influência da variação térmica, a retração, as imperfeições, choques ou colisões e os terremotos. No entanto, o dimensionamento do modelo adotado não demonstra erro, mas o projeto de Sussekind está mais a favor da segurança. O dimensionamento das demais seções analisadas, apresentam valores muito próximo.

Devido a pequena resistência a tração, as estruturas de concreto estão sensíveis às variações da temperatura, e dependendo dessa variação e amplitude dos movimentos, as tensões provocadas podem ser superiores à resistência a tração do concreto e gerar fissuras, que foi o caso da laje de cobertura, descrito no Capítulo 4. 

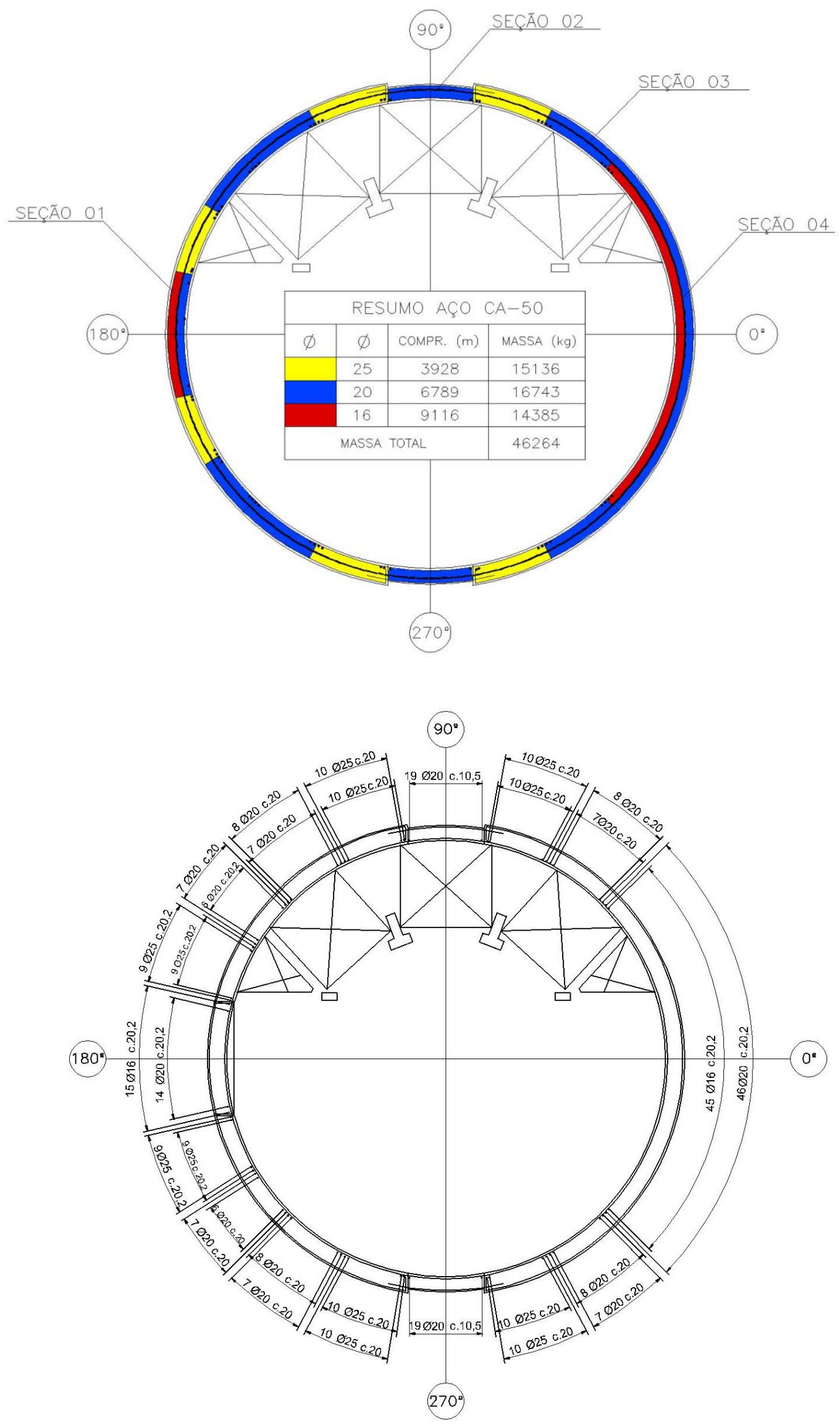

Figura 54 - Distribuição da armadura do fuste da Torre (projeto original), da elevação $6,0 \mathrm{~m}$ a $+42,30 \mathrm{~m}$, adaptado projeto Cad 2D - NOVACAP 


\subsection{COMPARAÇÃO DOS RESULTADOS DA MODELAGEM COM OS DADOS DE BESSA ET AL. (2013)}

Foram realizadas comparações dos resultados encontrados na modelagem com os dados obtidos por Bessa et al. (2013) na análise da estabilidade global da Torre de TV Digital, mencionado no item 2.2.5.

Quanto aos deslocamentos horizontais máximos atuantes na torre de concreto obtidos por Bessa et al. (2013), a partir da análise numérica realizado no programa SAP2000, baseado nos métodos dos elementos finitos, chegou-se a um deslocamento no topo de 7,7 cm. Observou-se também a partir da análise realizada no programa FTOOL, considerando a Torre como haste engastada na base e sendo submetido a ação do vento, um deslocamento de $8,35 \mathrm{~cm}$, obtendo assim, uma diferença de 7,7\% quanto ao seu próprio análise realizado pelo MEF.

Já a presente pesquisa, a partir da utilização do programa computacional SAP2000, baseado no MEF, chegou-se a um deslocamento horizontal no topo da torre de concreto de $3,90 \mathrm{~cm}$, como foi mencionado no item 5.4.1.

Essas distorções de resultados nos programas computacionais utilizados, podem ser explicadas pelas condições de contorno, do tipo de elementos finitos adotados, das sobrecargas consideradas e da diferenciação na formulação matemática. Já os valores de esforços normais e momentos fletores foram próximos em ambos.

Bessa et al. (2013) com os dados obtidos no ensaio de túnel de vento mencionado no item 3.2 , optou por adotar deslocamento no topo da torre proporcionais às forças obtidas no ensaio, encontrando um fator de correção de $0,53, \log$ o deslocamento no topo $(\delta \mathrm{t}) \mathrm{da}$ torre de concreto corrigido seria de $8,35 \mathrm{~cm}$ x 0,53 , ou seja, $\delta$ t igual a $4,42 \mathrm{~cm}$.

O deslocamento corrigido de Bessa et al. (2013) de 4,42 cm é próximo do valor encontrado nessa pesquisa que foi de $3,90 \mathrm{~cm}$, demonstrando uma certa segurança nas análises estruturais, apesar da diferença de $11,7 \%$ entre os valores, apresentando um bom desempenho estrutural para estado limite de serviço.

Tanto Bessa et al. (2013), quanto esta pesquisa realizada, obtiveram as armaduras da estrutura da torre de concreto, e os devidos valores encontrados foram confrontados com as armaduras especificadas no projeto, atendendo a norma brasileira vigente. 


\section{PROPOSTAS DE MANUTENÇÃO PARA A TORRE DE TV DIGITAL DE BRASÍLIA}

\subsection{INTRODUÇÃO}

Com o intuito de preservar e garantir uma vida útil e longa para esse monumento, serão estabelecidas propostas de manutenção seguindo as metodologias e recomendações do Conselho Internacional de Monumentos e Sítios - ICOMOS (2001) vista no Capítulo 02, sobre conservação do bem ou da obra edificada para preservar as características que apresentem uma significação cultural, preservando o valor estético, histórico, cientifico e social, além de segurança e funcionalidade para a qual foi determinada.

Para o desenvolvimento de propostas de manutenções para a estrutura da Torre de TV Digital, é tomado como base o gráfico (desempenho x tempo - Figura 31). Com o intuito de se obter um melhor entendimento, o gráfico foi dividido em trechos e adaptado a Torre, como mostra a Figura 55.

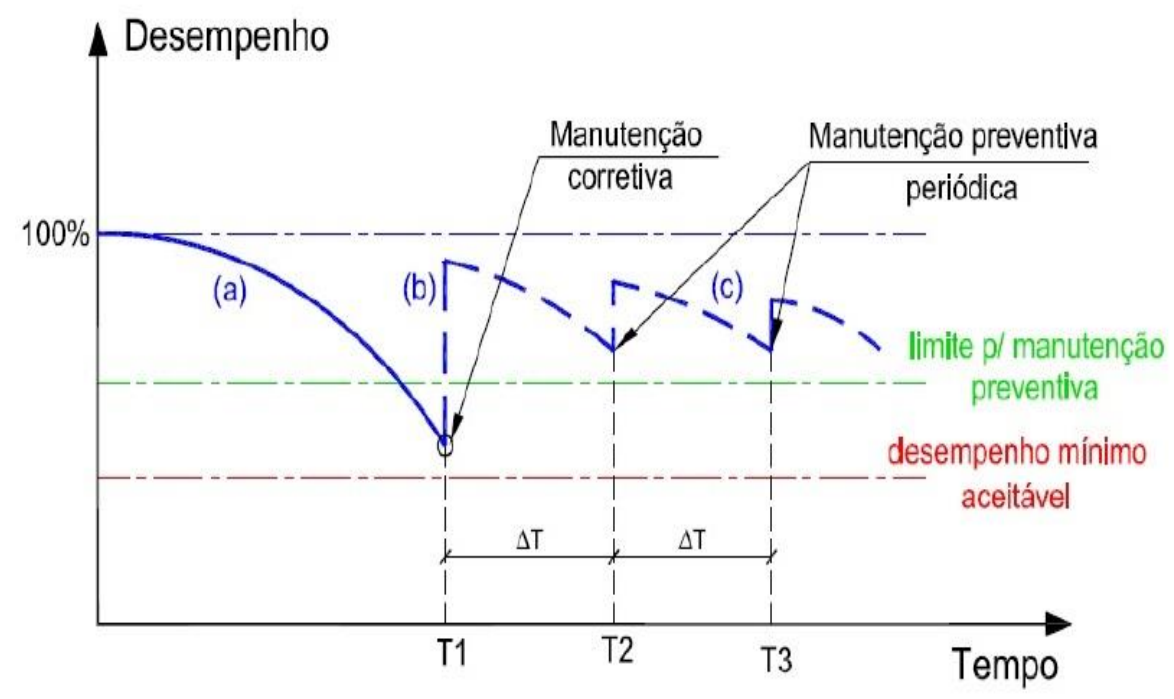

Figura 55 - Proposta de modelo para o desempenho da Torre de TV Digital de Brasília apud Moreira (2007)

Tomando como base a proposta de Moreira (2007), o trecho (a) busca representar o desempenho atual da Torre de TV Digital de Brasília, onde o grau de deterioração das estruturas de concreto (Gd) é nível médio, como se pode observar, já ultrapassando o limite para manutenção preventiva, sendo necessárias manutenções corretivas de alguns elementos estruturais afetados ou danificados, de modo a reestabelecer às condições de desempenho favorável, com nível satisfatório representado pelo trecho (b) como mostra o gráfico da Figura 55. 
No entanto, para manter esse desempenho satisfatório e ideal, é necessária a implantação de manutenção preventiva periódica para garantir a extensão da vida útil da Torre, simulado pelo trecho (c).

\subsection{MANUTENÇÃO CORRETIVA}

O procedimento de correção dos elementos estruturais se baseia em um conjunto de ações técnicas que se propõem a recuperar, reforçar ou até mesmo substituir parte (s) do sistema, para que venha ter um desempenho satisfatório e assim contribuir para uma extensão da vida útil do monumento.

A Tabela 36 apresenta os resultados obtidos e prazos máximos de intervenção para cada família de elementos vistoriados (inspeções visuais) e avaliados por meio da metodologia GDE/UnB.

Tabela 36 - Prazos para intervenção dos elementos estruturais da Torre de TV Digital de Brasília

\begin{tabular}{|c|c|c|c|}
\hline Elementos & Gdf & $\begin{array}{c}\text { Nivel de } \\
\text { deterioração }\end{array}$ & Prazo para intervenção \\
\hline Fuste (pilar parede) & 37,41 & Médio (15-50) & $\begin{array}{l}\text { Manutenção corretiva } \\
\text { (médio prazo - } 2 \text { anos) }\end{array}$ \\
\hline Braços & 29,05 & Médio (15-50) & $\begin{array}{l}\text { Manutenção corretiva } \\
\text { (médio prazo - } 2 \text { anos) }\end{array}$ \\
\hline Pilares & 29,05 & Médio (15-50) & $\begin{array}{l}\text { Manutenção corretiva } \\
\text { (médio prazo - } 2 \text { anos) }\end{array}$ \\
\hline Junta de dilatação & 22,00 & Médio (15-50) & $\begin{array}{l}\text { Manutenção corretiva } \\
\text { (médio prazo - } 2 \text { anos) }\end{array}$ \\
\hline Vigas & 36,39 & Médio (15-50) & $\begin{array}{l}\text { Manutenção corretiva } \\
\text { (médio prazo - } 2 \text { anos) }\end{array}$ \\
\hline Lajes & 76,96 & Alto $(50-80)$ & $\begin{array}{l}\text { Manutenção corretiva } \\
\text { (médio prazo - } 1 \text { ano) }\end{array}$ \\
\hline Escada & 3,36 & Baixo (0-15) & $\begin{array}{l}\text { Manutenção Preventiva } \\
\text { (Estado aceitável) }\end{array}$ \\
\hline Rampas & 30,00 & Médio (15-50) & $\begin{array}{l}\text { Manutenção corretiva } \\
\text { (médio prazo - } 2 \text { anos) }\end{array}$ \\
\hline Bloco fundação & 28,00 & Médio (15-50) & $\begin{array}{l}\text { Manutenção corretiva } \\
\text { (médio prazo - } 2 \text { anos) }\end{array}$ \\
\hline Elemento Arquitetônico & 2,40 & Baixo (0-15) & $\begin{array}{l}\text { Manutenção Preventiva } \\
\text { (Estado aceitável) }\end{array}$ \\
\hline Cortina (muro arrimo) & 0,0 & Baixo (0-15) & $\begin{array}{l}\text { Manutenção Preventiva } \\
\text { (Estado aceitável) }\end{array}$ \\
\hline Reservatórios & 0,0 & Baixo (0-15) & $\begin{array}{l}\text { Manutenção Preventiva } \\
\text { (Estado aceitável) }\end{array}$ \\
\hline
\end{tabular}


De acordo com a Tabela 36, a maioria das manifestações patológicas encontradas apontaram um nível de deterioração médio, sendo necessária a realização de reparos ou até mesmo reforço desses elementos estruturais. A seguir são apresentadas, de forma sucinta, propostas de soluções (reparo ou reforço) para estes elementos diagnosticados, com um grau de deterioração médio (15-50) e nível alto de deterioração (50-80):

- Laje de cobertura: As inúmeras fissuras existentes devem ter como causa a movimentação térmica, e acredita-se não ser nociva à estrutura. Uma alternativa para a correção dessas pequenas fissuras, seria preparar e limpar a superfície cuidadosamente, restaurando o elemento com a aplicação de produtos cimentícios para obter uma boa aderência e resistência no local. Além de efetuar uma proteção térmica e aplicar impermeabilização adequada, para melhorar a estética, pois sua visão é desagradável aos visitantes.

- Laje do espelho d'água: toda a laje necessita de reparos, principalmente para a retirada de fissuras, optando pela limpeza e aplicação de produtos cimentícios, preocupando-se em refazer a laje com juntas de dilatação para que não ocorram fissuras futuras e uma impermeabilização adequada para voltar o funcionamento do espelho d'água.

- Viga (anel do espelho d'água): fazer limpeza e restauração de toda a borda desse espelho, com retirada de algumas fissuras excessivas e aplicação de uma impermeabilização adequada para que o elemento volte as suas condições de funcionamento.

- Pilares: os pilares do espelho d'água apresentam manchas e pequenas fissuras que são apenas de cunho estético, propondo-se nesse elemento a limpeza para retiradas de manchas e refazer pintura para retornar sua beleza. Já os pilares ou pórticos do subsolo necessitam do término do reboco e pintura.

- Braços: na parte externa, fazer correção de pequenas fissuras, com preparação e limpeza da superfície, restaurando o elemento com a aplicação de produtos cimentícios e refazer a pintura, para recuperar a estética do monumento. Já na parte interna, fazer um recapeamento da cobertura do revestimento da impermeabilização na área afetada pelas infiltrações, com a aplicação de produtos cimentícios nessa região. 
- Fustes e rampa monumental: de forma generalizada, todo o monumento necessita das retiradas de pequenas fissuras e manchas, ou seja, precisa de um restauro na pintura e no acabamento para adquirir sua estética inicial.

- Nas passarelas de acesso às cúpulas: observou- se uma deficiência nas calhas de captação das águas pluviais, indicando por questões de segurança a mudança do sistema de descidas de água para que infiltrações futuras não venham a ocorrer. Além do concerto do sistema de esgoto a vácuo, para voltar o funcionamento normal das cúpulas que ainda faltam carpetes em uma delas, se mostrando falho a impermeabilização e a acústica do espaço.

Após as realizações das intervenções e manutenções corretivas indicadas, o monumento passará por manutenções preventivas para que possa ter um desempenho satisfatório e se tenha um prolongamento da sua vida útil.

\subsection{MANUTENÇÃO PREVENTIVA}

Antes de firmar um programa de manutenção preventiva e os intervalos de inspeções, é importante acompanhar os elementos reparados nos primeiros anos de intervenções, para avaliar se as providências cumpriram as funções para qual foi determinada, ou seja, observar se os reparos foram bem-sucedidos e visualizar se os danos foram estabilizados.

Os intervalos de tempo para a realização dessa observação visual ou inspeções, são definidos com a metodologia da Federação Internacional da Protensão para Estruturas de Concreto Armado e Protendido - FIB (1988), onde os intervalos são fixados de acordo com categoria e a classificação da estrutura em classes, combinações com o tipo de condição ambiental e de carregamento.

A Torre de TV Digital de Brasília se enquadra na classe 3 e com o tipo de condição ambiental e carregamento normal, indicando apenas inspeções superficiais, sendo rotineiras e extensivas. No entanto, devido a importância histórica e cultural do monumento recomenda-se:

- Inspeções rotineiras superficiais realizadas em intervalos regulares de três anos, estimado pela equipe técnica responsável pelos projetos e pela manutenção da estrutura, com elaboração de planilhas específicas e investigação dos elementos elencados, a fim de coletar dados, possíveis danos e agentes agressivos. 
- Inspeções extensivas superficiais realizadas em intervalos regulares de seis anos, alternadamente com as rotineiras, com o objetivo de investigar minuciosamente os elementos e as características dos materiais componentes da estrutura.

Para as realizações dessas inspeções propõe-se a criação de um corpo técnico de engenharia para a Torre, sendo dois engenheiros, um arquiteto e um técnico em edificações, para realizar o planejamento de atividades de investigação das estruturas de concreto, que poderia ser baseado na metodologia GDE/UnB utilizado nessa pesquisa.

Chegou- se a esses números para a formação do corpo técnico para a Torre de TV Digital de Brasília, a partir do estudo de caso de vários trabalhos desenvolvidos no PECC-UnB nessa mesma linha de pesquisa: "Patologia, Manutenção, Análise e Recuperação das Estruturas" sob as orientações dos professores João Carlos Teatini e Antônio Alberto Nepomuceno. 


\section{CONCLUSÕES}

\subsection{CONSIDERAÇÕES GERAIS}

O conjunto arquitetônico de Brasília com sítio tombado pela UNESCO em 1987, dá o título de patrimônio cultural da humanidade a capital. Reconhecendo a importância dos monumentos brasileiros construído nessa cidade, justificando assim, a necessidade de tomar medidas de preservação e manutenção periódica para garantir a extensão da vida útil desses edifícios emblemáticos.

Portanto, o objetivo desse trabalho foi a avaliação dos elementos estruturais da Torre de TV Digital de Brasília, observando os aspectos principais, como segurança, durabilidade, funcionalidade e estética, a fim de proporcionar um programa de manutenção para prolongamento da vida útil do edifício.

No entanto, para a realização dessa avaliação estrutural de maneira confiável, é necessário fazer uma combinação de abordagens para que possa tornar eficiente o diagnóstico sobre a segurança, funcionalidade e estética. Essas abordagens buscam levantar o máximo de informações possíveis para se ter um bom conhecimento do monumento, destaca-se:

- Análise histórica (documentos, projetos, etc);

- Análise qualitativos (levantamento, investigação, etc.);

- Análise quantitativos ( ensaios, modelos matemáticos, etc.).

Todas essas abordagens associada à análise numérica da estrutura fornecem o melhor julgamento da situação física atual do edifício, resultando em uma avaliação da sua segurança com uma certa confiabilidade.

\subsection{HISTÓRIA, PROJETOS E INTERVENÇÕES}

As informações gerais sobre a Torre de TV Digital de Brasília que estão contidas no Capítulo 3 são poucas, mas de maneira geral buscou-se:

- Descrever a história do monumento, o projeto, a estrutura, o planejamento executivo, as intervenções, as etapas de construção, os materiais empregados, as tecnologias construtivas, a execução da obra e as empresas envolvidas.

- Estudou a concepção arquitetônica do último projeto de Oscar Niemeyer executado em Brasília, em que a estrutura da Torre vista em um formato de "flor" se divide 
em: fuste (corpo principal da Torre, e vai da base até o cálice), os braços (de sustentação das cúpulas), as cúpulas (na cota de $60 \mathrm{~m}$ encontra a cúpula de exposição e na cota de $80 \mathrm{~m}$ fica a cúpula bar café) e o cálice (região onde fica o mirante com vista $360^{\circ}$ e onde está fixada a torre metálica). A torre de concreto conta ainda com um subsolo que serve de central técnica, com uma rampa monumental, um grande espelhos d'água, além de espaços de apoio a visitação e emissoras.

- Estudou o projeto estrutural de José Carlos Sussekind, onde as plantas com desenhos originais da estrutura da Torre Digital foram cedido pela NOVACAP, e foram essenciais para caracterizar a concepção adotada e permitir uma análise mais precisa do seu desempenho estrutural.

Observou-se que a fundação é constituída de um bloco de concreto de $25 \mathrm{~m}$ de diâmetro por 4,5 m de altura, apoiado sobre 246 estacas do tipo raiz, com $41 \mathrm{~cm}$ de diâmetro e $12 \mathrm{~m}$ de profundidade cada. Já o fuste é o corpo principal da Torre, tem um formato em parede circular de concreto armado ou pilar parede, na qual resiste aos esforços solicitados, como o esforço normal devido ao peso próprio da estrutura e o momento fletor causado devido às forças horizontais provenientes da ação do vento.

Nos braços de sustentação das cúpulas, foi feito uma protensão no nível superior de cada haste, para combater os grandes deslocamentos verticais ( flechas) e evitar a corrência de fissuras e outras patologias. O concreto utilizado no fuste, braços e cálice é especial de alto desempenho com um "Slump 5", que utiliza aditivos retardadores de pega para diminuir o tempo de início da cura.

A torre metálica fixada no cálice é formada a partir da conexão de vários segmentos ou tubos metálicos ligados por parafusos de alta resistência, sendo $50 \mathrm{~m}$ de estrutura metálica e $12 \mathrm{~m}$ de antena.

- Por fim, notou que a obra recém inaugurada em 2012 mesmo com detalhes a se fazer recebeu o Habite-se dando condições de funcionamento e uso para seus usuários. No entanto, foi interditada em 2014 após fiscalização técnica feita pelo TCU, principalmente devido o surgimento de alguns problemas e patologias, como manchas e fissuração. Sendo reaberta em 2015 após a realizações de todas as 
intervenções, sobre a responsabilidade da empreiteira consórcio Mendes Júnior Atrium, o monumento nunca teve seu funcionamento normalizado ao público.

\subsection{QUANTIFICAÇÃO DA DETERIORAÇÃO DA ESTRTUTURA DA TORRE PELA METODOLOGIA GDE/UnB}

Com as informações coletadas, pode-se realizar a avaliação da condição física atual da Torre utilizando a metodologia GDE/UnB, como mostra no Capítulo 4. Em que destacam os aspectos:

- Com a aplicação da metodologia GDE/UnB para quantificar o grau de deterioração da estrutura da torre conforme o Capítulo 4, pôde-se obter um nível de deterioração da estrutura igual à $\mathrm{Gd}=28,27$, sendo médio $(\mathrm{Gd}: 15-50)$ e alertando para a necessidade de traçar um planejamento de intervenções em no máximo dois anos. Estes resultados são considerados coerentes e reflete a real situação física de parte do edifício. A metodologia GDE/UnB mostra-se adequada para a aplicação neste tipo de estrutura.

- Como os resultados não indicam um nível crítico, ou seja, sem a necessidade de uma inspeção emergencial ou não havendo necessidades de intervenções imediatas, optando-se assim, pela não realização de ensaios, exceto, na laje de cobertura e na laje do espelho d'água por apresentarem um nível alto de deterioração (50-80) devem ser investigadas minuciosamente.

Os parâmetros especificados nos projetos e a inspeção à obra, foram suficientes para caracterizar as propriedades dos materiais e diagnosticar as causas dos fenômenos progressivos nos elementos estruturais. No entanto, se esses pequenos danos encontrados não forem combatidos, pode ocorrer o aumento da deterioração e requerer maiores investigações e maiores gastos para resolver o problema.

- Portanto, de forma geral, a metodologia GDE/UnB desenvolvida no PECC, a partir de Castro (1994) e última atualização feita por Fonseca (2007), apontou um nível de deterioração médio para a maioria dos elementos estruturais observados e alguns apresentaram nível baixo. No entanto, a laje de cobertura e a laje do espelho d' água por apresentarem inúmeras fissuras devido a variação térmica, indicaram um nível alto de deterioração, alertando para a realização de intervenção em no máximo um ano. 
- A partir dos valores obtidos, foram listadas medidas de manutenção corretiva para recuperar alguns elementos que apresentaram um nível médio e alto, e manutenção preventiva ou periódica para os elementos estruturais que apresentaram um nível baixo de deterioração, com o propósito de garantir a extensão da vida útil do edifício.

\subsection{ANÁLISE NUMÉRICA DA ESTRUTURA PELO MÉTODO DOS ELEMENTOS FINITOS}

Com o objetivo de analisar o comportamento da estrutura da Torre de TV Digital, foi idealizado um modelo no programa computacional SAP2000, onde é feito uma verificação do seu desempenho estrutural (ELS) e verificação do dimensionamento (ELU), conforme mostra no Capítulo 5, onde se pode destacar:

- Na verificação aos estados limite de serviço (ELS) foram analisados estado limite de deslocamento, considerando deslocamentos horizontais, verticais (flechas) e rotação no topo da torre, ambos atendem os limites estabelecidos pela norma ABNT NBR 6118:20014, dando condições de utilizações da torre aos usuários, demostrando um bom desempenho estrutural.

- No análise dos pavimentos, especificamente nas lajes, de forma geral apresentaram pequenas flechas ou baixo deslocamento vertical, exceto nas lajes de sustentação da cúpula de exposição e da cúpula bar café que houve flechas mis expressivas, sendo de $6,51 \mathrm{~cm}$ e $7,82 \mathrm{~cm}$, respectivamente. No entanto estão dentro do limite estipulado pela norma vigente que é de $10 \mathrm{~cm}$, conforme o deslocamento limite em estado de deformação excessiva da estrutura que é de L/250.

Mesmo assim, os engenheiros envolvidos, por motivo de segurança e eficácia na construção, optaram por utilizar contraflechas na execução dos braços de sustentação das cúpulas, exatamente onde os deslocamentos verticais foram maiores, sendo que no nível superior de cada braço foi feito uma protensão com intuito de combater esses deslocamentos e ainda absorver as cargas desses consoles.

- Quanto aos deslocamentos horizontais, obteve-se um valor de 3,90 cm no topo da torre de concreto e $10,73 \mathrm{~cm}$ no topo da antena metálica, ambos atendendo às prescrições quanto ao deslocamento provocado pelo vento que é de H/1700 e, aos deslocamentos horizontais máximos que é igual a H/500. Já a rotação no topo da 
estrutura de concreto foi de 0,00165 rad, estando também dentro do limite da norma ABNT NBR 6118:2014 que é de 0,0017 rad. Pode-se notar também que as tensões atuantes na torre são baixas em relação a resistência de compressão limite do concreto e as tensões atuantes de tração são absorvidas pelas armaduras especificadas.

- Quanto aos deslocamentos horizontais corrigidos no topo da estrutura de concreto de Bessa et al. (2013) de 4,42 cm são próximos dos valores encontrados nessa pesquisa, que foi de $3,90 \mathrm{~cm}$, demonstrando uma certa segurança nas análises estruturais, apesar da diferença de $11,7 \%$ entre os valores, apresentando um bom desempenho estrutural para estado limite de serviço.

- Na verificação dos estados limite ultimo (ELU), em relação a armadura especificada nas pranchas de detalhamento do projeto versus armaduras calculadas pela presente análise, mostra que as armaduras projetadas para a Torre de TV Digital de Brasília, atendem tanto o dimensionamento estrutural quanto às prescrições normativas e quanto à armadura mínima.

- A verificação do dimensionamento para o primeiro trecho da torre (fuste de $50 \mathrm{~cm}$ ) foi feita a partir da obtenção dos valores de esforço normal $(\mathrm{Nd})$ e momento fletor (Md1) pelo programa computacional. Esses esforços sofrem mudanças na parede circular de concreto de acordo com a variação do seu ângulo. A partir desses esforços foram considerados os efeitos de segunda ordem e os esforços majorados foram $(\mathrm{Nd})$ e $(\mathrm{Md} 2)$, com esses dados foi calculada a armadura e a mesma confrontada com o projeto orginal, a qual atende as especificações exigidas pela norma. Nota-se também que a fuste de concreto foi dividida em faixas (seções), onde funcionam como uma espécie de pilar parede que é resistente aos esforços máximos solicitados.

- Pode-se observar no dimensionamento da seção S2, que houve uma diferença expressiva de $10 \varnothing 20$ para $19 \varnothing 20$, nas abordagens do projeto de José Carlos Sussekind e do modelo adotado. Essa diferença pode ser explicada pela não consideração da influência da variação térmica, a retração, as imperfeições, choques ou colisões e os terremotos. As demais seções dimensionadas apresentaram valores próximos aos especificados no projeto original. No entanto, o dimensionamento do modelo adotado não demonstra erro, mas o projeto de Sussekind está mais a favor da segurança. 
- Vale ressaltar que não foram encontrados nenhuma relação entre o desempenho estrutural e as patologias observadas. No entanto, esse conjunto de abordagens foi essencial para se ter um diagnóstico preciso sobre a situação física atual do monumento e principalmente para melhor traçar o programa de manutenção.

\subsection{PROGRAMA DE MANUTENÇÃO PARA A ESTRUTURA DA TORRE DE TV DIGITAL DE BRASÍLIA}

O objetivo final deste trabalho foi propor estratégias para um programa de manutenção para a estrutura da Torre de TV Digital de Brasília, conforme mostra o Capítulo 6. Pode-se destacar:

- Mesmo com as obras de reparos feita pela empreiteira consórcio Mendes Júnior Atruim após interdição do monumento, feita em 2014, pelo corpo técnico do TCU, a obra nunca teve seu funcionamento normalizado e continua a apresentar problemas. Foi realizada uma inspeção à Torre e a quantificação do grau de deterioração pela metodologia GDE/UnB, apontou um nível médio de deterioração na maiorias dos elementos observados, alertando para a necessidade de traçar um planejamento de intervenções em no máximo dois anos. Para a família de elementos das lajes o nível de deterioração foi alto, alertando para intervenção de no máximo um ano.

- Em vista das condições físicas atuais em que se encontra a Torre, e pela importância da conscientização da manutenção e conservação do patrimônio brasileiro, e para que a maioria dos monumentos históricos ou obras públicas não acabem se deteriorando por falta de cuidados e restauros necessários, foi proposto um programa de manutenção corretiva e preventiva para o edifício.

As manutenções corretivas têm o intuito de reparar os danos encontrados e as preventivas têm o propósito de manter a obra sempre com o seu bom desempenho.

- Com o intuito de acompanhar o desempenho das medidas necessárias para a correção de alguns elementos estruturais e de realizar manutenções preventivas, sugere-se que as inspeções superficiais sejam realizadas com base em um programa que seja específico para a Torre de TV Digital. 
Pela importância histórica e cultural do monumento recomenda-se realizar inspeções rotineiras em intervalos regulares de três anos e inspeções extensivas em intervalos regulares de seis anos.

- Para as realizações dessas inspeções propõe-se a criação de um corpo técnico de engenharia para a Torre de TV Digital de Brasília, sendo dois engenheiros, um arquiteto e um técnico em edificações, para o planejamento de atividades de investigação das estruturas de concreto, que poderia ser baseado na metodologia GDE/UnB. Chegou-se a esses números para a formação do corpo técnico para a Torre Digital de Brasília, a partir do estudo de casos de vários trabalhos desenvolvidos no PECC-UnB nessa mesma linha de pesquisa: "Patologia, Manutenção, Análise e Recuperação das Estruturas" sob as orientações dos professores João Carlos Teatini e Antônio Alberto Nepomuceno.

\subsection{SUGESTÕES PARA TRABALHOS FUTUROS}

Brasília, Patrimônio Cultural da Humanidade - única cidade construída no século XX com esse título, possui um conjunto arquitetônico de extrema importância para o Brasil e o mundo, e traz consigo, a conscientização da manutenção periódica desses monumentos, para garantir principalmente, a durabilidade e segurança das estruturas.

Em 9 de fevereiro de 2007, o Diário Oficial da União publicou a qualificação pelo Ministério da Justiça como Organização Social Civil de Interesse Público (Oscip) da BelaBrasília - Preservação do Patrimônio Arquitetônico de Brasília:

A responsabilidade pela manutenção desses monumentos é de tal importância que deveria estar a cargo de uma instituição específica, sem fins lucrativos, com autonomia de gestão e fontes especiais de fomento, com participação ativa dos poderes executivos - federal e distrital -, Congresso Nacional, Câmara Legislativa, entidades da sociedade e, até mesmo, de organismos internacionais. (CLÍMACO, 2016).

Portanto, é recomendável que continue desenvolvendo trabalhos de natureza semelhante para que possa estender a vida útil dos diversos edifícios existentes nesse Sítio tombado, preenchendo assim, a história da arquitetura e engenharia brasileira que vem sendo pouca relatada. 
Pode-se listar outras edificações que foram citadas nesta pesquisa, as quais ainda não tiveram a oportunidade de serem avaliadas e muito menos proposto um programa de manutenção, a destacar:

- Outras obras emblemáticas tombadas pelo o IPHAN;

- Edifícios desse dos ministérios ;

- Supremo Tribunal Federal;

- O Congresso Nacional ;

- Palácio da Alvorada;

- Palácio do Planalto,

- Memorial JK e outras.

Além do desenvolvimento dos trabalhos específicos para a continuação desta linha de pesquisa "Patologia, Manutenção, Análise e Recuperação das Estruturas", sugere-se:

- Extensão da metodologia GDE/UnB para sistema de revestimentos, como cerâmicas, pastilhas, azulejos e ladrilhos, onde se pode estender também para outros elementos estruturais, como alvenaria estrutural, metálica, madeira. Além da extensão do "roteiro de inspeção" proposto por Fonseca (2007).

- Elaboração de um programa estratégico emergencial de manutenção das estruturas dos monumentos de Brasília, com auxílio de recurso dos órgãos federais e do Distrito Federal.

- Utilizar a medodologia GDE/UnB para avaliar as condições físicas, não só dos monumentos da capital, mas também de outras cidades brasileira.

- Elaborar um estudo para obtenção de dados quantitativos, através da realização de ensaios em alguns elementos estruturais da Torre de TV Digital, com o intuito de levantar propriedades dos materiais, como resistência a compressão do concreto e do módulo de elasticidade, que deverão ser obtidos por meios de testemunhos de concreto extraído da torre ou por meio de testes realizados em laboratórios para determinar essas características. E assim, contruíbuir para implantação de um programa de manutenção mais preciso e mais consistente. 


\section{REFERÊNCIAS BIBLIOGRÁFICAS}

ASSOCIAÇÃO BRASILEIRA DE ENGENHARIA E CONSULTORIA ESTRUTURAL, ABECE. Checklist para vistorias de edificações em concreto armado. Recife, PE, 2005. ASSOCIAÇÃO BRASILEIRA DE NORMAS TÉCNICAS, ABNT. Ações e Segurança nas Estruturas - Procedimento. NBR 8681. Rio de Janeiro, RJ, 2003.

ASSOCIAÇÃO BRASILEIRA DE NORMAS TÉCNICAS, ABNT. Projetos de estrutura de concreto- Procedimento. NBR 6118. Rio de Janeiro, RJ, 2003.

ASSOCIAÇÃO BRASILEIRA DE NORMAS TÉCNICAS, ABNT. Projetos de estrutura de concreto armado - Procedimento. NBR 6118. Rio de Janeiro, RJ, 2014.

ASSOCIAÇÃO BRASILEIRA DE NORMAS TÉCNICAS, ABNT. Forças devidas ao vento em edificações. NBR 6123. Rio de Janeiro, RJ, 1988.

ASSOCIAÇÃO BRASILEIRA DE NORMAS TÉCNICAS, ABNT. Manutenção de Edificações - Procedimento. NBR 5674. Rio de Janeiro, RJ, 1999.

ASSOCIAÇÃO BRASILEIRA E CONSULTORIA ESTRUTURAL, ABECE (2005). Check list para vistorias de edificações em concreto armado. Recife, PE.

ArPDF (várias datas). Fotografias e Documentos. Arquivo Público do Distrito Federal, Brasília, Brasil.

ARAÚJO, J.M. Análise do processo aproximado da NBR-6118 para consideração dos efeitos localizados de segunda ordem. Departamento de Materiais e Construção - FURG - Rio Grande, RS. Teoria e Prática na Engenharia Civil, n.10, p.1-10, Julho, 2007.

ARAÚJO, J. M. Métodos simplificados para consideração dos efeitos de segunda ordem no projeto de pilares de concreto armado. Revista do IBRACON, No. 27, p. 312, São Paulo, Novembro /Dezembro, 2001.

Araújo, J.M. Análise do processo aproximado da NBR-6118 para consideração dos efeitos localizados de segunda ordem. Departamento de Materiais e Construção - FURG - Rio Grande, RS. Teoria e Prática na Engenharia Civil, n.10, p.1-10, Julho, 2007.

BESSA, M. A. et al.Análise de estabilidade da torre Tv digital de Brasília. Cilamce, Pirenópolis - Go, Brasil, 2013. 
BOLDO, P. (2002). Avaliação quantitativa de estruturas de concreto armado de edificações no âmbito do Exército Brasileiro. Dissertação de Mestrado, Programa de Pós-graduação em Estruturas e Construção Civil, UnB, Brasília, 295 pp.

CASTRO, E.K.(1994). Desenvolvimento de Metodologia para manutenção de estruturas de Concreto armado. Dissertação de Mestrado, Universidade de Brasília, DF,185p,dezembro.

CUNHA, J.C. Inspeção, uso e manutenção em estruturas de concreto. In: seminário estruturas de concreto para obras de saneamento ( $1^{\circ}$. SECOS). Belo Horizonte, 2006.

EUQUERES, P. Metodologia de inspeção de pontes de concreto armado. Dissertação de mestrado, Escola de Engenharia Civil, Universidade Federal de Goiás, Goiânia, GO, 2011. 168p.

FÉDÉRATION INTERNATIONALE DE LA PRÉCONTRAINTE - FIP. Guide to good pratice: inspection and maintenance of reinforced and presstressed concrete structure. Londres, Thomas Telford Publications, 1988.

SOARES F.S. et al. (2016). Análise numérica da estrutura da torre de Tv digital de Brasília. Cilamce, Brasília - DF, Brasil, 2016.

FONSECA, R. P.da. (2007). A Estrutura do Instituto Central de Ciências da Universidade de Brasília: Aspectos Históricos e Tecnológico de Projeto, execução e Propostas de Manutenção. Dissertação de Mestrado, Programa de Pós-graduação em Estruturas e Construção Civil, Universidade de Brasília, Brasília, DF.

GORGulho, S. A Flor do Cerrado: Torre de TV digital de Brasília. 1. ed. Brasília: folha do meio ambiente, 2012.

GESUALDO, F. A. R. Notas de aulas: Métodos dos elementos finitos-MEF. Programa de Pós-graduação em Engenharia Civil, Universidade Federal de Uberlândia-UFU, Minas Gerais-MG, 2010.

HELENE, P. R. L.(1992). Manual para reparo, reforço e proteção de estruturas de concreto armado. Editora PINI, São Paulo, SP.

ICOMOS, COMITÊ CIENTÍFICO INTERNACIONAL PARA ANÁLISE E RESTAURAÇÃO DE ESTRUTURAS DO PATRIMÔNIO ARQUITETÔNICO. Recomendações para análise, conservação e restauração estrutural do patrimônio arquitetônico. Tradução de Silvia Puccioni, IPHAN, Paris, 2001. 
Inojosa, L. S. P., Buzar, M. A. R, de Gregorio M.H. R. Aspectos do Projeto Estrutural do Museu Nacional de Brasília. Anais do XXXIII Congresso Ibero Latino-Americano de Métodos Computacionais para Engenharia (XXXIII CILAMCE), Ouro Preto, 2011.

JOPPERT. J. I. (2007). Fundações e contenções em edifícios: qualidade total na gestão de projeto e execução. São Paulo: Pini.

KLEIN, D.; GASTAL. F.; CAMPANOLO, J.L.; SILVA FILHO, L.C. (1991). Critérios adotados na vistoria e avaliação de obras de arte. XXV Jornadas Sul americanas de Engenharia Estrutural, Porto Alegre, Anais, pp 185-196, novembro.

LOPES, B.A.R. (1998). Sistema de manutenção predial para grandes estoques de edifícios: estudo para inclusão do componente estrutura de concreto. Dissertação de Mestrado, Universidade de Brasília, Brasília, DF, 308p, setembro.

LEAL, P. D. (2014). Torre Digital: plano de marketing para uma atração turística da capital federal. Trabalho final de graduação, curso de comunicação social, universidade de Brasília, UnB, Brasília, Brasil.

MOREIRA, A.L.A (2007). A Estrutura do Palácio da Justiça em Brasília: aspectos Históricos, Científicos e Tecnológico de Projeto, execução, intervenções e proposta de estratégias para manutenção. Dissertação de Mestrado, programa de pós-graduação em estruturas e construção civil. Universidade de Brasília, UnB, Brasília, Brasil.

MACGREGOR, J.G; WIGHT, J.K.(2009). Reinforced Concrete: Mechanics and Design. 6 th. United States af America - USA.

M. A. Bessa, M. A. R. Buzar, L. S. Silva, L. S. P. Inojosa. CILAMCE 2013-Proceedings of the XXXIV Iberian Latin-American Congress on Computational Methods in Engineering. Z.J.G.N Del Prado (Editor), ABMEC, Pirenópolis, GO, Brazil, November 10-13, 2013.

NOVACAP (várias datas). Projetos Arquitetônicos e Estruturais. Companhia Urbanizadora da Nova Capital do Brasil, Brasília, Brasil.

MELO, C. E. L. (2016). Análise Estrutural com o SAP 2000. Departamento de tecnologia-TEC, Faculdade de Arquitetura e Urbanismo. Universidade de Brasilia, UnB, Brasilia- DF.

NIEMEYER, O. Forma e função na arquitetura. Revista de Arquitetura e Artes Visuais no Brasil. Rio de Janeiro, ${ }^{\circ}$.21, dezembro 1960. 
PESSOA, D.F. (2002). A estrutura da Catedral de Brasília: aspectos históricos, científicos, e tecnológicos de projeto, execução, intervenções e proposta de manutenção. Dissertação de Mestrado, Programa de Pós-graduação em Estruturas e Construção Civil, UnB, Brasília, Brasil, 243 pp.

RICARDO, R.B. (2002). Investigação do nível de deterioração de estruturas de concreto armado: estudo de caso no Campus da Universidade Estadual de Maringá. Dissertação de Metrado, Programa de Pós-graduação em Engenharia civil, área de construção Civil. Universidade Federal de Santa Catarina, UFSC, Florianópolis, SC, Brasil.

SOUZA, D.A.S (2009). A Estrutura do Teatro Nacional Claudio Santoro em Brasília: Histórico de projeto, execução, intervenções e estratégias para manutenção. Dissertação de Mestrado, programa de pós-graduação em estruturas e construção civil. Universidade de Brasília, UnB, Brasília, Brasil.

SILVA, L.S.P (2008). A Estrutura do Monumento a Caxias e do teatro Pedro Calmon em Brasília: Histórico de projeto, execução, intervenções e estratégias para manutenção. Dissertação de Mestrado, programa de pós-graduação em estruturas e construção civil. Universidade de Brasília, UnB, Brasília, Brasil.

SANTOS JÚNIOR, E.C.R. (2004). A estrutura do Palácio do Itamaraty: aspectos históricos, científicos, e tecnológicos de projeto, execução, intervenções e recomendações de manutenção. Dissertação de Mestrado, Programa de Pós-graduação em Estruturas e Construção Civil, UnB, Brasília, Brasil, 188 pp.

SOUZA, V.C.M. e RIPPER T. (1999). Patologia, recuperação e reforço de estrutura de concreto. Editora PINI, São Paulo, SP.

TAMAKI, L. Revista Techne Pini de engenharia civil: Flor do Cerrado. 168.ed. Brasília, 2011.

VASCONCELOS, J.A. A epopéia da construção de Brasília. 224p. ilustradas. BrasíliaDF, 1989.

VASCONCELOS, A.C. de - O concreto no Brasil: Recordes - Realizações - História, volume 1. São Paulo, editora PINI, 1992.

VASCONCELOS, A.C. de - O concreto no Brasil: Professores - Cientistas - Técnicos, Volume 2. São Paulo, editora PINI, 1992. 
VERLY, R. C. Avaliação de metodologias de inspeção com o instrumento de priorização de intervenções em obras de artes especiais. Dissertação de mestrado, Programa de Pós-graduação em Estruturas e Construção Civil-PECC, Universidade de Brasília, UnB, Brasília, DF, 2015.198p.

VENÂNCIO. P. B. F. (2008). Dosagem de argamassa para estaca raiz. Dissertação de mestrado, programa de pós-graduação em estruturas e construção civil. Universidade de Brasília, UnB, Brasília, Brasil.

\section{FONTES DE INTERNET}

Fonte: Disponível em: <http://techne.pini.com.br/engenharia-civil/168/artigo2878211.aspx>, acesso em: 02/04/16.

Fonte: <http://portal.iphan.gov.br/>, acesso em: 02/04/16.

Fonte: Disponível em: <https://nacoesunidas.org/agencia/unesco/>, acesso em: 02/04/16.

Fonte: Disponível em: <https://www.turismoinformativo.com.br/wpcontent/uploads/2016 01/congresso-1-of-1.jpg>. Acesso em: 14/01/2017.

Fonte: Disponível em: < http://vemviverbrasilia.blogspot.com.br/2011/08/palacio-daalvorada.html >. Acesso em: 14/01/2017.

Fonte: Disponível em: < http://www.copa2014.gov.br/sites/default/files/palacio-do planalto_cristiano-mascaro-2006_820.jpg>. Acesso em: 14/01/2017.

Fonte: Disponível em: <http://www.cidadebrasilia.com.br/turismo/image/interest/mainIma ge/2000/supremo-tribunal-federal.jpg>. Acesso em: 14/01/2017.

Fonte: Disponível em: <http://farm8.staticflickr.com/7562/16023452196_512ddc38c9.jp. Acesso em: 17/01/2017.

Fonte: Disponível em: < http://www.brasiliafacil.com/wp-content/uploads/palacio-dajustica-brasilia-df.jpg >. Acesso em: 17/01/2017.

Fonte: Disponível em: < http://techne.pini.com.br/engenharia-civil/168/flor-do-cerradoproximo-a-brasilia-estrutura-de-182-287821-1.aspx>. Acesso em: 18/01/2017.

Fonte: Disponível em: < http://techne.pini.com.br/engenharia-civil/168/flor-do-cerradoproximo-a-brasilia-estrutura-de-182-287821-1.aspx >. Acesso em: 18/01/2017.

Fonte: Disponível em: < http://convergecom.com.br/wp-content/uploads/2015/05/Torre TV-digital-Bras\%C3\%ADlia.jpg>, acesso em: 02/04/16.

Fonte: $<$ http://www.noticias.unb.br/artigos-main/1131-viadutos-de-brasilia-cuidadeo-como-que-vem-de-cima>. Publicado na página web da UnB, em 13/12/2016. 
APÊNDICES 


\section{APÊNDICE A: PLANILHAS COM OS RESULTADOS DA INSPEÇÃO NA TORRE DE TV DIGITAL DE BRASÍLIA, SEgUNDO A METODOLOGIA GDE/UnB}

\section{INSPEÇÃO NA ESTRUTURA DA TORRE DE TV DIGITAL DE BRASÍLIA-DF}

Tabelas: Planilhas famílias de elementos estruturais da Torre de TV digital

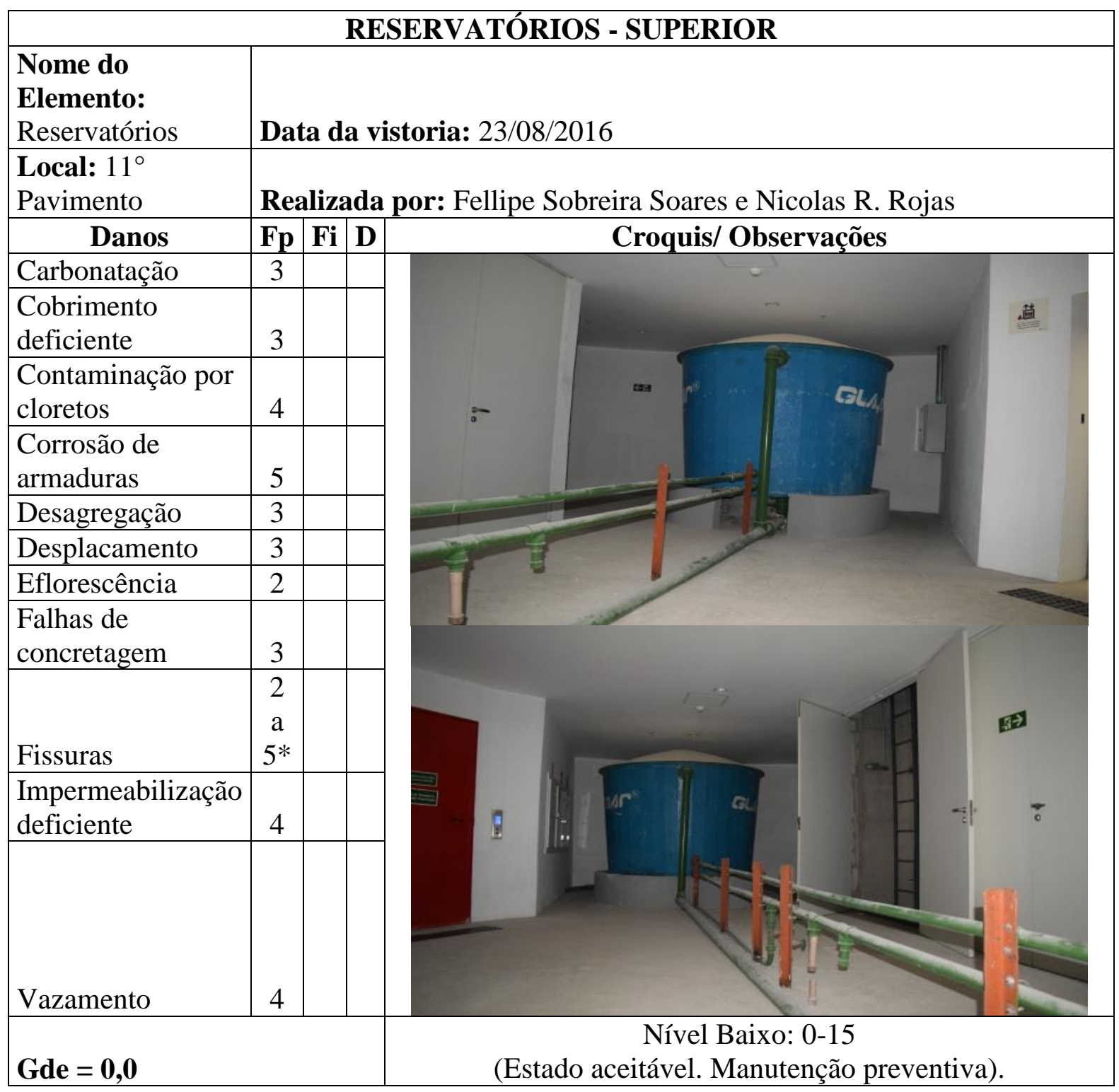




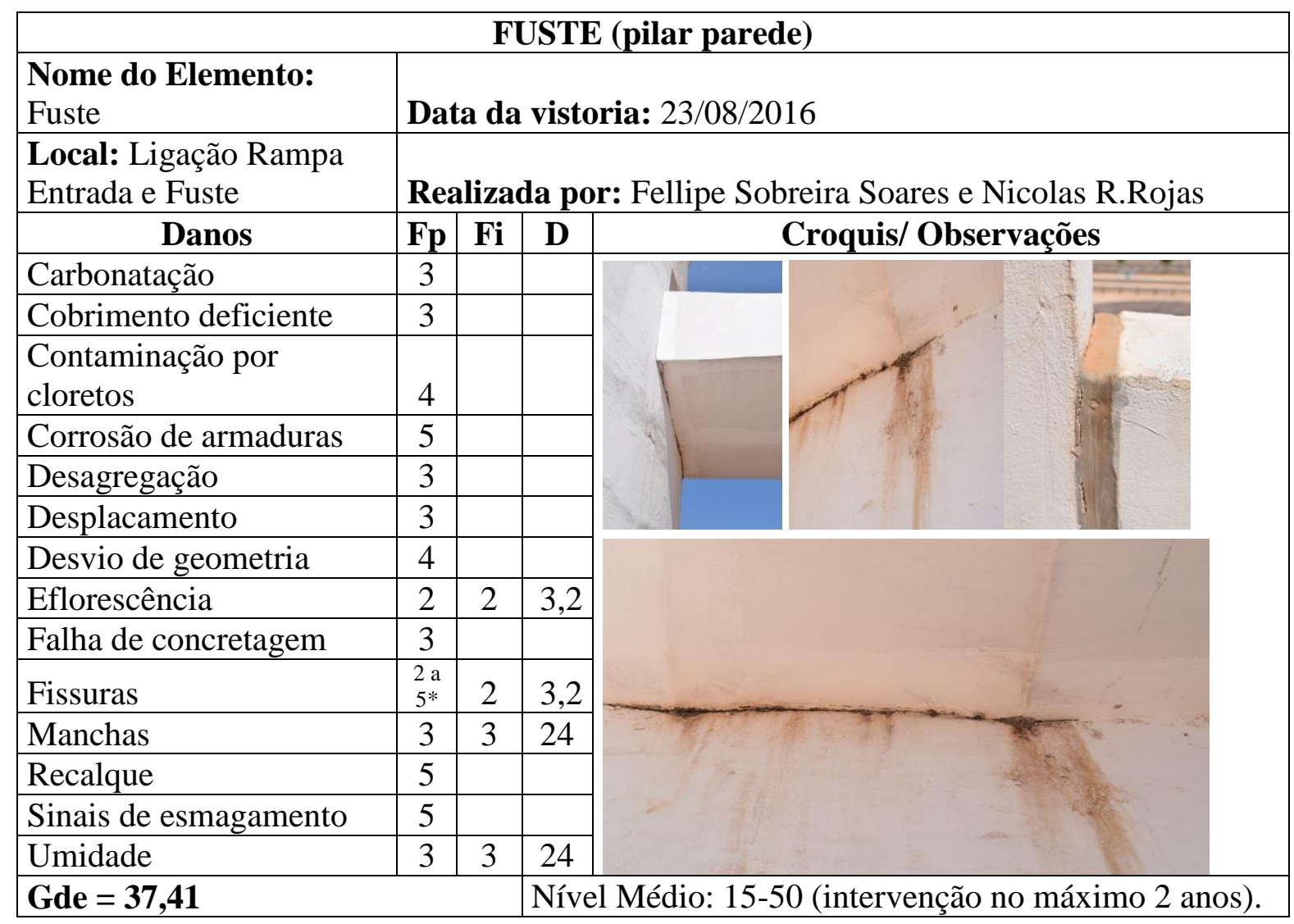

\begin{tabular}{|c|c|c|c|c|c|}
\hline \multicolumn{6}{|c|}{ FUSTE (pilar parede) } \\
\hline $\begin{array}{l}\text { Nome do Elemento: } \\
\text { Fuste }\end{array}$ & \multicolumn{5}{|c|}{ Data da vistoria: $23 / 08 / 2016$} \\
\hline Local: Fachada & \multicolumn{5}{|c|}{ Realizada por: Fellipe Sobreira Soares e Nicolas R. Rojas } \\
\hline Danos & Fp & $\mathbf{F i}$ & D & Cro & s/ Observações \\
\hline Carbonatação & 3 & & & & \\
\hline Cobrimento deficiente & 3 & & & & \\
\hline $\begin{array}{l}\text { Contaminação por } \\
\text { cloretos }\end{array}$ & 4 & & & & \\
\hline Corrosão de armaduras & 5 & & & & \\
\hline Desagregação & 3 & & & & \\
\hline Desplacamento & 3 & & & & \\
\hline Desvio de geometria & 4 & & & & \\
\hline Eflorescência & 2 & & & & \\
\hline Falha de concretagem & 3 & 1 & 2,4 & & \\
\hline Fissuras & $\begin{array}{l}2 \mathrm{a} \\
5 * \\
\end{array}$ & 1 & 1,6 & & \\
\hline Manchas & 3 & 2 & 4,8 & & \\
\hline Recalque & 5 & & & & \\
\hline Sinais de esmagamento & 5 & & & & \\
\hline Umidade na base & 3 & & & & \\
\hline Gde $=6,98$ & & & & $\begin{array}{r}\mathrm{N} \\
\text { (Estado aceitá } \\
\end{array}$ & $\begin{array}{l}1 \text { Baixo: 0-15 } \\
\text { Manutenção preventiva). }\end{array}$ \\
\hline
\end{tabular}




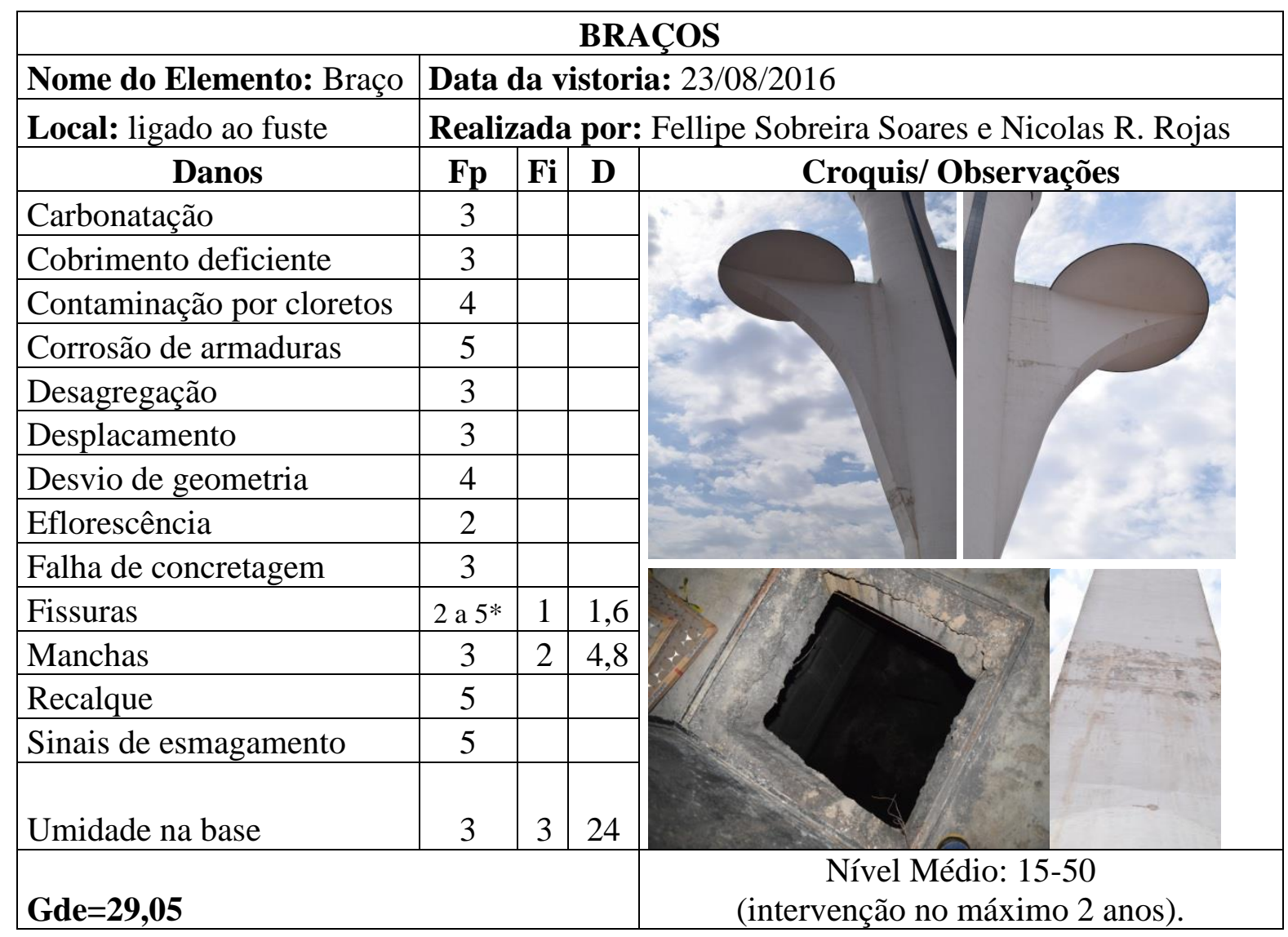

\begin{tabular}{|c|c|c|c|c|}
\hline \multicolumn{5}{|c|}{ FUSTE (pilar parede) } \\
\hline $\begin{array}{l}\text { Nome do Elemento: } \\
\text { Fuste }\end{array}$ & \multicolumn{4}{|c|}{ Data da vistoria: $23 / 08 / 2016$} \\
\hline $\begin{array}{l}\text { Local: parede circular de } \\
\text { concreto }\end{array}$ & \multicolumn{4}{|c|}{ Realizada por: Fellipe Sobreira Soares e Nicolas R. Rojas } \\
\hline Danos & $\mathbf{F p}$ & $\mathbf{F i}$ & $\mathbf{D}$ & Croquis/ Observações \\
\hline Carbonatação & 3 & & & \\
\hline Cobrimento deficiente & 3 & & & \\
\hline $\begin{array}{l}\text { Contaminação por } \\
\text { cloretos }\end{array}$ & 4 & & & \\
\hline Corrosão de armaduras & 5 & & & \\
\hline Desagregação & 3 & & & \\
\hline Desplacamento & 3 & & & \\
\hline Desvio de geometria & 4 & & & \\
\hline Eflorescência & 2 & & & \\
\hline Falha de concretagem & 3 & 1 & 2,4 & \\
\hline Fissuras & 2 a $5 *$ & 1 & 2,4 & 19 \\
\hline Manchas & 3 & 2 & 4,8 & \\
\hline Recalque & 5 & & & \\
\hline Sinais de esmagamento & 5 & & & \\
\hline Umidade na base & 3 & & & \\
\hline Gde $=7,2$ & & & & $\begin{array}{c}\text { Nível Baixo: 0-15 } \\
\text { (Estado aceitável. Manutenção preventiva). }\end{array}$ \\
\hline
\end{tabular}




\begin{tabular}{|c|c|c|c|c|}
\hline \multicolumn{5}{|c|}{ PILARES } \\
\hline $\begin{array}{l}\text { Nome do } \\
\text { Elemento: } \\
\text { Pilares }\end{array}$ & \multicolumn{4}{|c|}{ Data da vistoria: $23 / 08 / 2016$} \\
\hline $\begin{array}{l}\text { Local: Rampa } \\
\text { Entrada }\end{array}$ & \multicolumn{4}{|c|}{ Realizada por: Fellipe Sobreira Soares e Nicolas R. Rojas } \\
\hline Danos & Fp & $\mathbf{F i}$ & $\mathbf{D}$ & Croquis/ Observações \\
\hline Carbonatação & 3 & & & \\
\hline $\begin{array}{l}\text { Cobrimento } \\
\text { deficiente }\end{array}$ & 3 & & & \\
\hline $\begin{array}{l}\text { Contaminação } \\
\text { por cloretos }\end{array}$ & 4 & & & \\
\hline $\begin{array}{l}\text { Corrosão de } \\
\text { armaduras }\end{array}$ & 5 & & & \\
\hline Desagregação & 3 & & & \\
\hline Desplacamento & 3 & & & \\
\hline $\begin{array}{l}\text { Desvio de } \\
\text { geometria }\end{array}$ & 4 & & & \\
\hline Eflorescência & 2 & & & \\
\hline $\begin{array}{l}\text { Falha de } \\
\text { concretagem }\end{array}$ & 3 & & & \\
\hline Fissuras & \begin{tabular}{|l|}
$2 \mathrm{a}$ \\
$5^{*}$ \\
\end{tabular} & 1 & 1,6 & \\
\hline Manchas & 3 & 3 & 24 & \\
\hline Recalque & 5 & & & \\
\hline $\begin{array}{l}\text { Sinais de } \\
\text { esmagamento }\end{array}$ & 5 & & & \\
\hline Umidade na base & 3 & 2 & 4,8 & \\
\hline Gde $=29,05$ & & & & $\begin{array}{l}\text { Nível Médio: } 15-50 \\
\text { ervenção no máximo } 2 \text { anos). }\end{array}$ \\
\hline
\end{tabular}

\begin{tabular}{|c|c|c|c|c|}
\hline \multicolumn{5}{|c|}{ JUNTAS DE DILATAÇÃO } \\
\hline Nome do Elemento: & \multicolumn{4}{|c|}{ Data da vistoria: $23 / 08 / 2016^{3}$} \\
\hline $\begin{array}{l}\text { Local: Laje espelho } \\
\text { d'água }\end{array}$ & \multicolumn{4}{|c|}{ Realizada por: Fellipe Sobreira Soares e Nicolas R. Rojas } \\
\hline Danos & $\mathbf{F p}$ & Fi & $\mathbf{D}$ & Croquis/ Observações \\
\hline Umidade na base & 3 & 2 & 1,6 & \\
\hline Umidade & 5 & 2 & 8 & \\
\hline Fissuras & 2 a $5^{*}$ & 3 & 16 & \\
\hline Gde $=22,0$ & & & & $\begin{array}{c}\text { Nível Médio: } 15-50 \\
\text { (intervenção no máximo } 2 \text { anos). }\end{array}$ \\
\hline
\end{tabular}




\begin{tabular}{|c|c|c|c|c|}
\hline \multicolumn{5}{|c|}{ PILARES } \\
\hline $\begin{array}{l}\text { Nome do Elemento: } \\
\text { Pilares }\end{array}$ & \multicolumn{4}{|c|}{ Data da vistoria: $23 / 08 / 2016$} \\
\hline Local: Interno (Shaft) & \multicolumn{4}{|c|}{ Realizada por: Fellipe Sobreira Soares e Nicolas R. Rojas } \\
\hline Danos & $\mathbf{F p}$ & $\mathbf{F i}$ & D & Croquis/ Observações \\
\hline Carbonatação & 3 & & & \\
\hline Cobrimento deficiente & 3 & & & \\
\hline $\begin{array}{l}\text { Contaminação por } \\
\text { cloretos }\end{array}$ & 4 & & & \\
\hline Corrosão de armaduras & 5 & & & \\
\hline Desagregação & 3 & & & \\
\hline Desplacamento & 3 & & & \\
\hline Desvio de geometria & 4 & & & \\
\hline Eflorescência & 2 & & & $=$ \\
\hline Falha de concretagem & 3 & 2 & 4,8 & 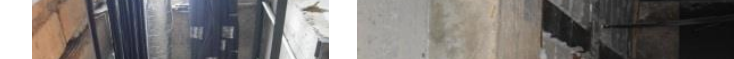 \\
\hline Fissuras & 2 a $5 *$ & & & 4 \\
\hline Manchas & 3 & & & 1 \\
\hline Recalque & 5 & & & + \\
\hline Sinais de esmagamento & 5 & & & $E$ \\
\hline Umidade na base & 3 & & & \\
\hline Gde $=4,8$ & & & & $\begin{array}{c}\text { Nível Baixo: 0-15 } \\
\text { (Estado aceitável. Manutenção preventiva). }\end{array}$ \\
\hline
\end{tabular}

\begin{tabular}{|c|c|c|c|c|}
\hline \multicolumn{5}{|c|}{ PILARES } \\
\hline $\begin{array}{l}\text { Nome do Elemento: } \\
\text { Pilares }\end{array}$ & \multicolumn{4}{|c|}{ Data da vistoria: $23 / 08 / 2016$} \\
\hline Local: Subsolo & \multicolumn{4}{|c|}{ Realizada por: Fellipe Sobreira Soares e Nicolas R. Rojas } \\
\hline Danos & Fp & $\mathbf{F i}$ & D & Croquis/ Observações \\
\hline Carbonatação & 3 & & & 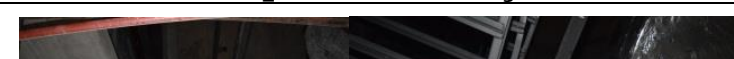 \\
\hline Cobrimento deficiente & 3 & & & \\
\hline $\begin{array}{l}\text { Contaminação por } \\
\text { cloretos }\end{array}$ & 4 & & & \\
\hline Corrosão de armaduras & 5 & & & \\
\hline Desagregação & 3 & & & \\
\hline Desplacamento & 3 & & & \\
\hline Desvio de geometria & 4 & & & \\
\hline Eflorescência & 2 & & & \\
\hline Falha de concretagem & 3 & 2 & 4,8 & \\
\hline Fissuras & 2 a $5 *$ & & & \\
\hline Manchas & 3 & & & \\
\hline Recalque & 5 & & & \\
\hline Sinais de esmagamento & 5 & & & \\
\hline Umidade na base & 3 & & & \\
\hline Gde $=4,8$ & & & & $\begin{array}{c}\text { Nível Baixo: 0-15 } \\
\text { (Estado aceitável. Manutenção preventiva). }\end{array}$ \\
\hline
\end{tabular}




\begin{tabular}{|l|c|c|c|c|}
\hline \multicolumn{5}{|c|}{ VIGAS } \\
\hline $\begin{array}{l}\text { Nome do Elemento: } \\
\text { Vigas (anel) }\end{array}$ & \multicolumn{3}{|c|}{ Data da vistoria: 23/08/2016 } \\
\hline Local: Espelho d'água & \multicolumn{2}{|c|}{ Realizada por: Fellipe Sobreira Soares e Nicolas R. Rojas } \\
\hline \multicolumn{1}{|c|}{ Danos } & Fp & Fi & D & Croquis/ Observações \\
\hline Carbonatação & 3 & & & \\
\hline Cobrimento deficiente & 3 & & & \\
\hline $\begin{array}{l}\text { Contaminação por } \\
\text { cloretos }\end{array}$ & 4 & & & \\
\hline Corrosão de armaduras & 5 & & & \\
\hline Desagregação & 3 & & & \\
\hline Desplacamento & 3 & 2 & 4,8 \\
\hline Eflorescência & 2 & & & \\
\hline Falhas de concretagem & 2 & & & \\
\hline Fissuras & 2 a 5* & 3 & 16 \\
\hline Manchas & 3 & 3 & 24 \\
\hline Flechas & 5 & & & \\
\hline Sinais de esmagamento & 4 & & & \\
\hline Umidade & 3 & 2 & 4,8 & \\
\hline Gde=36,38 & & & \\
\hline
\end{tabular}

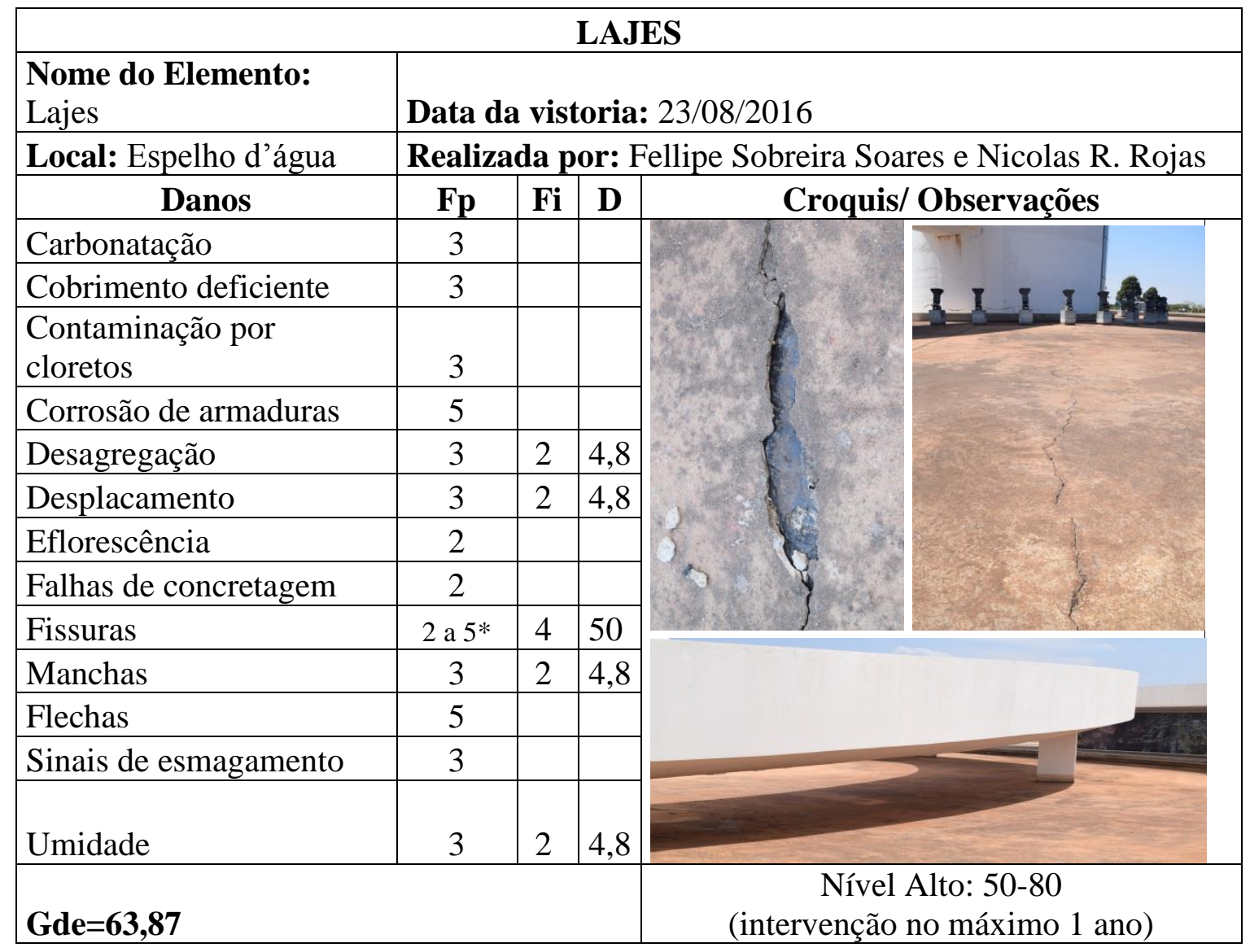




\begin{tabular}{|l|c|c|c|c|}
\hline \multicolumn{5}{|c|}{ LAJES } \\
\hline $\begin{array}{l}\text { Nome do Elemento: } \\
\text { Lajes }\end{array}$ & \multicolumn{3}{|c|}{ Data da vistoria: 23/08/2016 } \\
\hline Local: Cobertura & Realizada por: Fellipe Sobreira Soares e Nicolas R. Rojas \\
\hline \multicolumn{1}{|c|}{ Danos } & Fp & Fi & D \\
\hline Carbonatação & 3 & & \\
\hline Cobrimento deficiente & 3 & & \\
\hline $\begin{array}{l}\text { Contaminação por } \\
\text { cloretos }\end{array}$ & 3 & & \\
\hline Corrosão de armaduras & 5 & & \\
\hline Desagregação & 3 & & \\
\hline Desplacamento & 3 & 1 & 2,4 \\
\hline Eflorescência & 2 & & \\
\hline Falhas de concretagem & 2 & 3 & 16 \\
\hline Fissuras & 2 a 5* & 3 & 40 \\
\hline Manchas & 3 & & \\
\hline Flechas & 5 & & \\
\hline Sinais de esmagamento & 3 & & \\
\hline Umidade & 3 & & \\
\hline Gde=52,60 & & & \\
\hline
\end{tabular}

\begin{tabular}{|l|c|c|c|c|}
\hline \multicolumn{5}{|c|}{ LAJES } \\
\hline $\begin{array}{l}\text { Nome do Elemento: } \\
\text { Lajes }\end{array}$ & \multicolumn{3}{|c|}{ Data da vistoria: 23/08/2016 } \\
\hline Local: Passarela Cúpula & \multicolumn{2}{|c|}{ Realizada por: Fellipe Sobreira Soares e Nicolas R. Rojas } \\
\hline \multicolumn{1}{|c|}{ Danos } & Fp & Fi & D & Croquis/ Observações \\
\hline Carbonatação & 3 & & \\
\hline Cobrimento deficiente & 3 & & \\
\hline $\begin{array}{l}\text { Contaminação por } \\
\text { cloretos }\end{array}$ & 3 & & \\
\hline Corrosão de armaduras & 5 & & \\
\hline Desagregação & 3 & & \\
\hline Desplacamento & 3 & & \\
\hline Eflorescência & 2 & & \\
\hline Falhas de concretagem & 2 & & \\
\hline Fissuras & 2 a $5^{*}$ & & \\
\hline Manchas & 3 & 1 & 2,4 \\
\hline Flechas & 5 & & \\
\hline Sinais de esmagamento & 3 & & \\
\hline Umidade & 3 & 1 & 2,4 \\
\hline Gde=3,6 & & \\
\hline
\end{tabular}




\begin{tabular}{|c|c|c|c|c|}
\hline \multicolumn{5}{|c|}{ LAJES } \\
\hline $\begin{array}{l}\text { Nome do Elemento: } \\
\text { Lajes }\end{array}$ & \multicolumn{4}{|c|}{ Data da vistoria: $23 / 08 / 2016$} \\
\hline $\begin{array}{l}\text { Local: Demais } \\
\text { Pavimentos (Mirante) }\end{array}$ & \multicolumn{4}{|c|}{ Realizada por: Fellipe Sobreira Soares e Nicolas R. Rojas } \\
\hline Danos & $\mathbf{F p}$ & Fi & D & Croquis/ Observações \\
\hline Carbonatação & 3 & & & \\
\hline Cobrimento deficiente & 3 & & & 4 \\
\hline $\begin{array}{l}\text { Contaminação por } \\
\text { cloretos }\end{array}$ & 3 & & & \\
\hline Corrosão de armaduras & 5 & & & \\
\hline Desagregação & 3 & & & \\
\hline Desplacamento & 3 & & & \\
\hline Eflorescência & 2 & & & \\
\hline Falhas de concretagem & 2 & & & \\
\hline Fissuras & 2 a $5 *$ & & & \\
\hline Manchas & 3 & & & \\
\hline Flechas & 5 & & & \\
\hline Sinais de esmagamento & 3 & & & \\
\hline Umidade & 3 & & & \\
\hline Gde $=0,0$ & & & & $\begin{array}{c}\text { Nível Baixo: 0-15 } \\
\text { (Estado aceitável. Manutenção preventiva) }\end{array}$ \\
\hline
\end{tabular}

\begin{tabular}{|c|c|c|c|c|}
\hline \multicolumn{5}{|c|}{ ESCADAS } \\
\hline $\begin{array}{l}\text { Nome do Elemento: } \\
\text { Escadas }\end{array}$ & \multicolumn{4}{|c|}{ Data da vistoria: $23 / 08 / 2016$} \\
\hline Local: Todos Pavimentos & \multicolumn{4}{|c|}{ Realizada por: Fellipe Sobreira Soares e Nicolas R. Rojas } \\
\hline Danos & $\mathbf{F p}$ & $\mathbf{F i}$ & $\mathbf{D}$ & Croquis/ Observações \\
\hline Carbonatação & 3 & & & \\
\hline Cobrimento deficiente & 3 & & & \\
\hline $\begin{array}{l}\text { Contaminação por } \\
\text { cloretos }\end{array}$ & 4 & & & \\
\hline Corrosão de armaduras & 5 & & & \\
\hline Desagregação & 3 & & & \\
\hline Desplacamento & 3 & & & \\
\hline Eflorescência & 2 & & & \\
\hline Falhas de concretagem & 2 & & & \\
\hline Fissuras & 2 a $5 *$ & 1 & 1,6 & \\
\hline Manchas & 3 & & & \\
\hline Flechas & 5 & & & \\
\hline Sinais de esmagamento & 3 & & & \\
\hline Umidade & 3 & 1 & 2,4 & \\
\hline Gde $=3,36$ & & & & $\begin{array}{c}\text { Nível Baixo: 0-15 } \\
\text { (Estado aceitável. Manutenção preventiva) }\end{array}$ \\
\hline
\end{tabular}




\begin{tabular}{|c|c|c|c|c|}
\hline \multicolumn{5}{|c|}{ RAMPAS } \\
\hline Nome do Elemento: Rampa & \multicolumn{4}{|c|}{ Data da vistoria: $23 / 08 / 2016$} \\
\hline Local: Rampa Monumental & \multicolumn{4}{|c|}{ Realizada por: Fellipe Sobreira Soares e Nicolas R. Rojas } \\
\hline Danos & $\mathbf{F p}$ & $\mathbf{F i}$ & D & Croquis/ Observações \\
\hline Carbonatação & 3 & & & \\
\hline Cobrimento deficiente & 3 & & & \\
\hline Contaminação por cloretos & 4 & & & \\
\hline Corrosão de armaduras & 5 & & & \\
\hline Desagregação & 3 & & & \\
\hline Desplacamento & 3 & & & \\
\hline Eflorescência & 2 & & & \\
\hline Falhas de concretagem & 2 & & & \\
\hline Fissuras & $\begin{array}{l}2 \mathrm{a} \\
5^{*}\end{array}$ & 1 & 3,2 & D \\
\hline Manchas & 3 & 3 & 24 & \\
\hline Flechas & 5 & & & \\
\hline Sinais de esmagamento & 3 & & & \\
\hline Umidade & 3 & 2 & 4,8 & \\
\hline Gde $=30$ & & & & $\begin{array}{c}\text { Nível Médio: } 15-50 \\
\text { (intervenção no máximo } 2 \text { anos). }\end{array}$ \\
\hline
\end{tabular}

\begin{tabular}{|l|c|c|c|c|}
\hline \multicolumn{4}{|c|}{ CORTINAS OU MURO DE ARRIMO } \\
\hline $\begin{array}{l}\text { Nome do Elemento: } \\
\text { Muro Arrimo }\end{array}$ & \multicolumn{2}{|c|}{ Data da vistoria: $23 / 08 / 2016$} \\
\hline Local: Subsolo & \multicolumn{2}{|c|}{ Realizada por: Fellipe Sobreira Soares e Nicolas R. Rojas } \\
\hline \multicolumn{1}{|c|}{ Danos } & Fp & Fi & D & Croquis/ Observações \\
\hline Carbonatação & 3 & & & \\
\hline Cobrimento deficiente & 3 & & \\
\hline $\begin{array}{l}\text { Contaminação por } \\
\text { cloretos }\end{array}$ & 4 & & \\
\hline Corrosão de armaduras & 5 & & \\
\hline Desagregação & 3 & & \\
\hline Desplacamento & 3 & & \\
\hline Eflorescência & 2 & & \\
\hline Falhas de concretagem & 2 & & \\
\hline Fissuras & 2 a 5* & & \\
\hline Manchas & 3 & & \\
\hline Desvio de geometria & 3 & & \\
\hline Sinais de esmagamento & 5 & & \\
\hline Umidade & 3 & & \\
\hline $\begin{array}{l}\text { Desplacamento por } \\
\text { empuxo }\end{array}$ & 5 & & \\
\hline Desplacamento & 3 & & \\
\hline Gde=0,0 & & & \\
\hline
\end{tabular}




\begin{tabular}{|l|c|c|c|c|}
\hline \multicolumn{5}{|c|}{ BLOCO DE FUNDAÇÃO } \\
\hline $\begin{array}{l}\text { Nome do Elemento: } \\
\text { Bloco de Fundação }\end{array}$ & \multicolumn{3}{|c|}{ Data da vistoria: 23/08/2016 } \\
\hline $\begin{array}{l}\text { Local: Base torre } \\
\text { metálica }\end{array}$ & \multicolumn{2}{|c|}{ Realizada por: Fellipe Sobreira Soares e Nicolas R. Rojas } \\
\hline \multicolumn{1}{|c|}{ Danos } & Fp & Fi & D & Croquis/ Observações \\
\hline Carbonatação & 3 & & & \\
\hline $\begin{array}{l}\text { Cobrimento } \\
\text { deficiente }\end{array}$ & 3 & & \\
\hline $\begin{array}{l}\text { Contaminação por } \\
\text { cloretos }\end{array}$ & 4 & & \\
\hline $\begin{array}{l}\text { Corrosão de } \\
\text { armaduras }\end{array}$ & 5 & & \\
\hline Desagregação & 3 & & \\
\hline Desplacamento & 3 & 1 & 2,4 \\
\hline Eflorescência & 2 & & \\
\hline $\begin{array}{l}\text { Falhas de } \\
\text { concretagem }\end{array}$ & 3 & 3 & 24 \\
\hline Fissuras & 2 a 5* & 2 & 2,4 \\
\hline Recalque & 5 & & \\
\hline $\begin{array}{l}\text { Sinais de } \\
\text { esmagamento }\end{array}$ & 5 & & \\
\hline Umidade na base & 3 & & \\
\hline Gde=28,00 & & \\
\hline
\end{tabular}

\begin{tabular}{|c|c|c|c|c|}
\hline \multicolumn{5}{|c|}{ ELEMENTOS DE COMPOSIÇÃO ARQUITETÔNICA } \\
\hline Nome do Elemento: & \multicolumn{4}{|c|}{ Data da vistoria: $23 / 08 / 2016$} \\
\hline Local: Lojas / emissoras & \multicolumn{4}{|c|}{ Realizada por: Fellipe Sobreira Soares e Nicolas R. Rojas } \\
\hline Danos & $\mathbf{F p}$ & $\mathbf{F i}$ & $\mathbf{D}$ & Croquis/ Observações \\
\hline Carbonatação & 3 & & & \\
\hline Cobrimento deficiente & 3 & & & \\
\hline $\begin{array}{l}\text { Contaminação por } \\
\text { cloretos }\end{array}$ & 4 & & & \\
\hline Corrosão de armaduras & 5 & & & \\
\hline Desagregação & 3 & & & 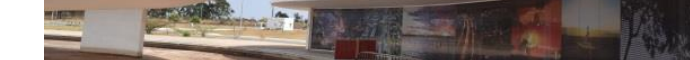 \\
\hline Desplacamento & 3 & & & \\
\hline Eflorescência & 2 & & & \\
\hline Falhas de concretagem & 2 & & & \\
\hline Fissuras & 2 a $5^{*}$ & & & \\
\hline Manchas & 3 & 1 & 2,4 & \\
\hline Sinais de esmagamento & 5 & & & \\
\hline Umidade & 3 & & & \\
\hline Gde $=2,40$ & & & & $\begin{array}{c}\text { Nível Baixo: 0-15 } \\
\text { (Estado aceitável. Manutenção preventiv }\end{array}$ \\
\hline
\end{tabular}




\section{APÊNDICE B - DEMONSTRAÇÃO DO CÁlCULO DAS COMBINAÇÕES DE AÇÕES PARA A TORRE DE TV DIGITAL DE BRASÍLIA, CONFORME PRESCRIÇÕES DA NORMA ABNT NBR 6118:2014}

\section{COMBINAÇÕES DE AÇÕES: ELU E ELS}

\subsection{COMBINAÇÕES ÚLTIMAS NORMAIS: ELU}

A equação (1) é utilizada na verificação do dimensionamento dos elementos estruturais:

$$
F d=\mathrm{Yg} * \mathrm{Fgk}+\mathrm{Y} \varepsilon \mathrm{g} * \mathrm{~F} \varepsilon \mathrm{gk}+\mathrm{Yq} *\left(\mathrm{Fq} 1 \mathrm{k}+\sum_{j=2}^{n} \psi o j * F q j k\right)+Y \varepsilon g * \psi o \varepsilon * F \varepsilon q k
$$

Onde: $\mathrm{Yg} * \mathrm{Fgk}=$ Carga permanente direta (peso próprio, empuxo, etc.).

$$
\begin{aligned}
& \mathrm{Y} \varepsilon \mathrm{g} * \mathrm{~F} \varepsilon \mathrm{gk}=\text { Carga permanente indireta (retração, imperfeições, etc.). } \\
& \mathrm{Yq} *\left(\mathrm{Fq} 1 \mathrm{k}+\sum_{j=2}^{n} \psi \text { oj } * F q j k\right)=\text { variáveis diretas (carga de uso, vento, etc.). } \\
& Y \varepsilon g * \psi o \varepsilon * F \varepsilon q k=\text { Variações Indiretas (temperatura, etc.). }
\end{aligned}
$$

Para essa combinação não foram definidas as ações permanentes indiretas (retração, imperfeições, etc.) e nem as ações variáveis indiretas (temperatura, etc.).

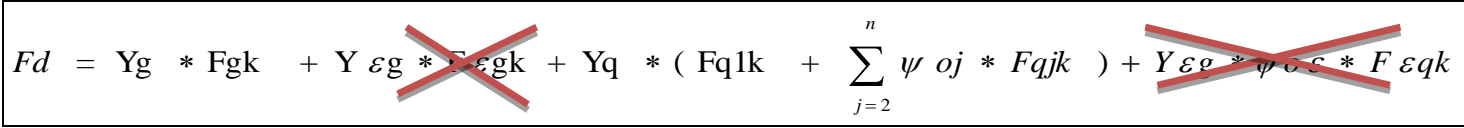

Os coeficientes ponderadores (majoradores $-\mathrm{Y}$ e redutores- $\psi$ ) foram obtidos pela norma ABNT NBR 6118:2014, nas tabelas 11.1 e 11.2, disponível na norma vigente.

Pp: Yg = 1,4(permanente direta normais) Tabela 11.1;

G: $\mathrm{Yg}=1,4$ (permanente direta normais) Tabela 11.1;

Q e V: Yq = 1,4(Carga variável direta) Tabela 11.1;

Q: $\psi$ o $=0,7$ (Edifício Público) Tabela 11.2;

$\mathrm{V}: \psi \mathrm{o}=0,6$ (Estruturas gerais) Tabela 11.2. 
Foram feito dois casos de combinações com carga variável direta principal (Fq1k - carga de Vento) e com carga variável direta principal (Fq1k - carga de uso):

Caso 01: combinações com carga variável direta principal (Fq1k - carga de Vento):

ELU 01: Fd=1,4 ( Pp+G) + 1,4 V1 + 0,98 Q (desfavorável);

ELU 02: $\mathrm{Fd}=1,4(\mathrm{Pp}+\mathrm{G})+1,4 \mathrm{~V} 2+0,98 \mathrm{Q}$.

Caso 02: combinações com carga variável direta principal (Fq1k - carga de uso).

ELU 03: $F d=1,4(P p+G)+1,4 Q+0,84$ V1;

ELU 04: Fd=1,4 ( Pp+G) + 1,4 Q + 0,84 V2.

\subsection{COMBINAÇÕES DE SERVIÇO: ELS}

Classifica as combinações de serviços em três tipos conforme as intensidades de sua permanência na estrutura: quase permanentes, frequentes e raras. Para avaliar o funcionamento da estrutura da torre de TV digital foram feito combinações para dois tipos: quase permanentes e as frequentes.

1) As combinações quase permanentes (CQP): verificação do estado limite de deformações excessivas, ELS-DEF, expressa na equação (2):

$\mathrm{Fd}$, ser $=\sum_{\mathrm{j}=1}^{\mathrm{n}} F g j k+\sum_{j=1}^{n} \psi 2 j * F q j k$

Onde: O primeiro termo, $\sum_{\mathrm{j}=1}^{\mathrm{n}} F g j k$, equivale às cargas permanentes e o segundo termo, $\sum_{j=1}^{n} \psi 2 j * F q j k$, corresponde às cargas variáveis.

Os coeficientes ponderadores (redutores- $\psi$ ) foram obtidos pela norma ABNT NBR 6118:2014, nas tabelas 11.2, disponível na norma vigente:

Q: $\psi 2 \mathrm{q}=0,4 ;$ (Edifício Público) Tabela 11.2 ;

$\mathrm{V}: \psi 2 \mathrm{v}=0,0 ;$ (Vento) Tabela 11.2.

Foram feito dois casos de combinações com carga variável direta principal (Fq1k - carga de Vento) e com carga variável direta principal (Fq1k - carga de uso):

Caso 01: combinações com carga variável direta principal (Fq1k - carga de Vento):

ELS 01: Fd,ser $=(P p+G)+0,0$ V1 + 0,4 Q; 
ELS 01: Fd,ser $=(P p+G)+0,0$ V2 + 0,4 Q.

Caso 02: combinações com carga variável direta principal (Fq1k - carga de uso).

ELS 01: Fd,ser $=(P p+G)+0,4 \mathrm{Q}+0,0$ V1;

ELS 01: Fd,ser $=(P p+G)+0,4 Q+0,0$ V2.

2) As combinações frequentes $(\mathrm{CF})$ : verificação do estado limite de fissuração, ELS-F; aberturas de fissuras (ELS-W) e vibrações excessivas (ELS-VIB), expressa na equação (3).

Fd, ser $=\sum_{\mathrm{j}=1}^{\mathrm{n}} F g j k+\psi 1 * F q 1 k+\sum_{j=2}^{n} \psi 2 j * F q j k$

Onde: O primeiro termo, $\sum_{\mathrm{j}=1}^{\mathrm{n}} F g j k$, equivale às cargas permanentes e o segundo termo, $\psi 1 *$ Fgjk $+\sum_{j=2}^{n} \psi 2 j * F q j k$, corresponde às cargas variáveis.

Os coeficientes ponderadores (redutores- $\psi$ ) foram obtidos pela norma ABNT NBR 6118:2014, nas tabelas 11.2, disponível na norma vigente.

Q: $\psi 1 \mathrm{q}=0,6 ; \psi 2 \mathrm{q}=0,4 ;($ Edifício Público) Tabela 11.2.

$\mathrm{V}: \psi 1 \mathrm{v}=0,3 ; \psi 2 \mathrm{v}=0,0 ;($ Vento) Tabela 11.2.

Foram feito dois casos de combinações com carga variável direta principal (Fq1k - carga de Vento) e com carga variável direta principal (Fq1k - carga de uso):

Caso 01: combinações com carga variável direta principal (carga de Vento):

ELS 02: Fd,ser $=(P p+G)+0,3 \mathrm{~V} 1+0,4 \mathrm{Q}$;

ELS 03: Fd,ser $=(P p+G)+0,3$ V2 + 0,4 Q(desfavorável $).$

Caso 02: combinações com carga variável direta principal (Fq1k - carga de uso).

ELS 04: Fd,ser $=(P p+G)+0,6 Q+0,0$ V1;

ELS 04: Fd,ser $=(P p+G)+0,6 Q+0,0$ V2.

A análise elástica linear admite-se um comportamento elástico-linear para os materiais. Segundo a norma ABNT NBR 6118:2014, esse tipo de análise é utilizado para a verificação aos estados limites de serviços (ELS) e para a verificação aos estados limites última (ELU), que é o objetivo da pesquisa. 
A norma ABNT NBR 6118:2014 informa ainda os valores limites para deslocamentos, máxima rotação, deformações e tensões máxima para estruturas de concreto armado:

- O deslocamento horizontal máximo é igual a H/500, 10 mm e a rotação máxima igual a $0,0017 \mathrm{rad}$;

- O deslocamento limite para verificação em serviço do estado de deformação excessivas da estrutura é de (L/250) e os deslocamentos limites devido a cargas acidentais é de $(\mathrm{L} / 350)$;

- O deslocamento provocado pela ação do vento para combinação frequente $(\psi 1=0,30)$ é de $\mathrm{H} / 1700$, onde $\mathrm{H}$ (altura edifício) e deformação máxima do concreto $\varepsilon \mathrm{c} 2=2,0 \%{ }^{\circ} \mathrm{e}$ $\varepsilon \mathrm{cu}=3,5 \%{ }^{\circ}$;

- A tensão máxima de compressão: $\sigma c=0,85 f c d\left[1-\left(1-\frac{\varepsilon c}{\varepsilon c 2}\right)^{n}\right] * E c i$, onde $\varepsilon c 2=0,002 \mathrm{e}$ $\varepsilon c=0,0035$ e tensão máxima de tração: $f_{c t}, m=0,3 f_{c k}{ }^{2 / 3}$, para concreto classe até C50. 


\section{APÊNDICE C - FORÇAS DEVIDO A AÇÃO DO VENTO $\left(0^{\circ}\right.$ E $\left.^{\circ} 0^{\circ}\right)$ PARA A TORRE DE TV DIGITAL, CONFORME PRESCRIÇÕES DA NORMA ABNT NBR 6123:1988}

\begin{tabular}{|c|c|c|c|c|}
\hline \multicolumn{5}{|c|}{ VENTO $(V 1)-90^{\circ}$} \\
\hline \multicolumn{2}{|r|}{ DADOS: } & \multicolumn{3}{|c|}{ PESQUISA REALIZADA: } \\
\hline \multicolumn{2}{|r|}{ Coeficiente de Arrasto } & $\begin{array}{c}\text { Cota } \\
\text { Piso (m) }\end{array}$ & $\begin{array}{c}\text { A,exp } \\
\text { (Área) (m2) }\end{array}$ & $\begin{array}{c}\mathbf{Q} \\
(\mathbf{K N} / \mathbf{m})\end{array}$ \\
\hline \multicolumn{2}{|r|}{ Formato Retângular } & 182,0 & 9,50 & 1,65 \\
\hline \multicolumn{2}{|r|}{$\mathrm{I} 1=63 \mathrm{~m}$} & 170,0 & 13,45 & 1,85 \\
\hline \multicolumn{2}{|r|}{$\mathrm{I} 2=12 \mathrm{~m}$} & 155,0 & 26,70 & 2,65 \\
\hline \multicolumn{2}{|c|}{$\mathrm{I} 1 / \mathrm{I} 2=5,25$} & 135,0 & 24,30 & 3,15 \\
\hline \multicolumn{2}{|c|}{ Figura 4: Gráfico NBR 6123:1988, Ca=1,42. } & 120,0 & 88,20 & 30,55 \\
\hline \multicolumn{2}{|c|}{$\mathrm{VK}=\mathrm{V} 0 * \mathrm{~S} 1 * \mathrm{~S} 2 * \mathrm{~S} 3$} & 114,5 & 90,87 & 31,2 \\
\hline \multicolumn{2}{|r|}{ Brasília-DF. } & 109,0 & 87,25 & 29,65 \\
\hline \multirow{4}{*}{$\begin{array}{c}S 1=1,00 \text { (Fixo) } \\
\text { S2: Fr }=0,95 \\
b=1,0 \\
p=0,1\end{array}$} & Terreno Plano, Vegetação Rasteira. & 103,5 & 79,10 & 26,6 \\
\hline & \multirow{3}{*}{$\begin{array}{l}\text { categoria II } \\
\text { Classe C } \\
\text { Altura }=120 \mathrm{~m}\end{array}$} & 98,0 & 124,28 & 25,15 \\
\hline & & 89,0 & 118,55 & 22,25 \\
\hline & & 79,5 & 307,72 & 59,6 \\
\hline \multirow[t]{2}{*}{$\mathbf{S 3}=1,10($ Fixo $)$} & Centro de Comunicação & 70,5 & 217,06 & 38,8 \\
\hline & Formato & 61,0 & 352,54 & 64,5 \\
\hline \multirow{3}{*}{$\mathrm{I} 2=12,00 \mathrm{~m}$} & \multirow[b]{3}{*}{$I 1=63 \mathrm{~m}$} & 52,0 & 244,84 & 40,95 \\
\hline & & 42,5 & 181,35 & 29 \\
\hline & & 33,0 & 149,95 & 22,65 \\
\hline & \multirow{4}{*}{ Vento } & 23,5 & 127,88 & 18,85 \\
\hline & & 14,5 & 118,55 & 14,45 \\
\hline & & 5,0 & 56,25 & 9,95 \\
\hline & & 0,0 & & \\
\hline
\end{tabular}


VENTO (V2) - $0^{\circ}$

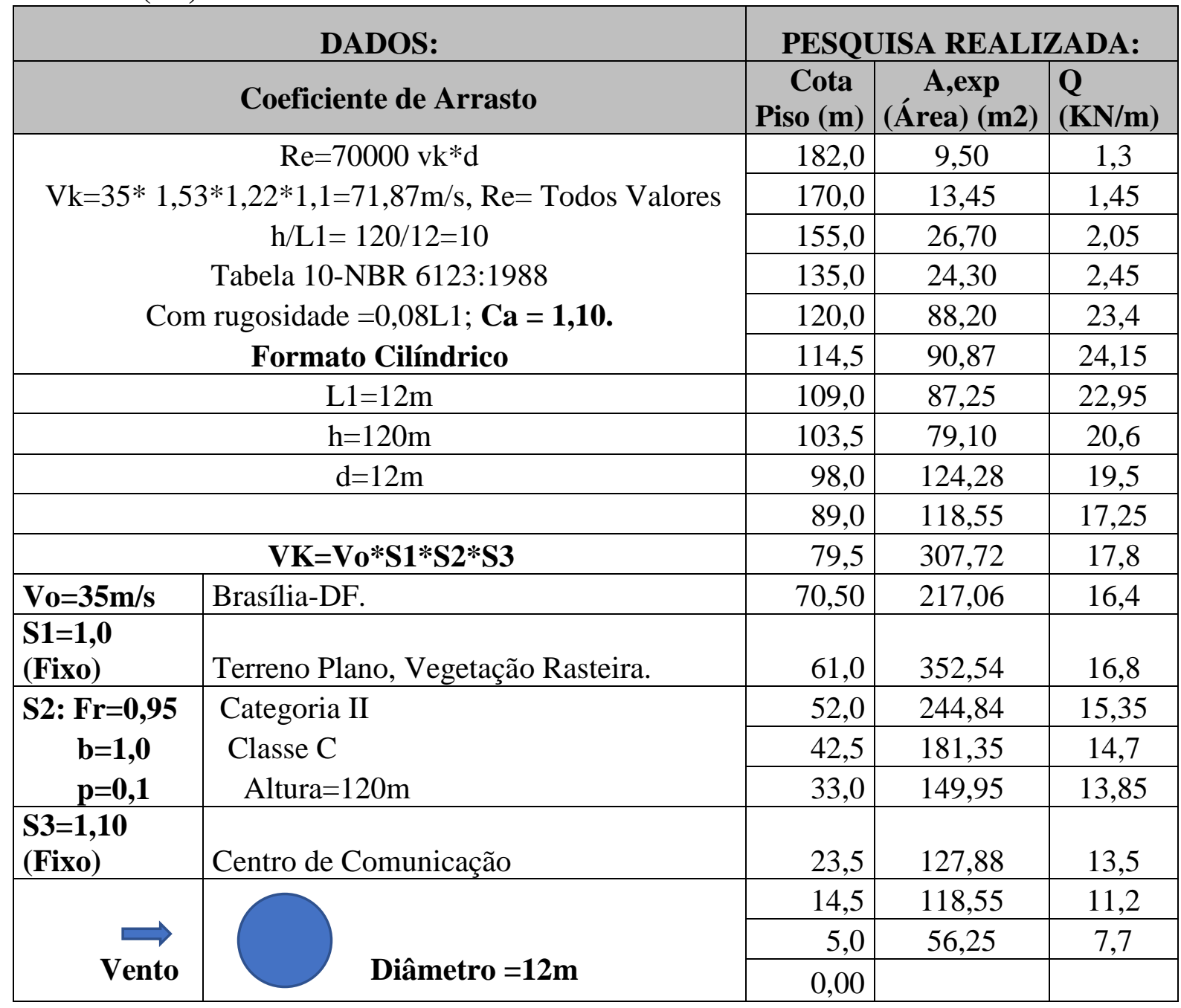


ANEXOS 


\section{ROTEIRO DE INSPEÇÃO (FONSECA, 2007)}

\section{ANEXO A: TIPOS DE DANOS MAIS FREQUENTES EM \\ ESTRUTURAS DE CONCRETO}

\section{INTRODUÇÃO:}

O presente Roteiro de Inspeções é parte integrante de uma metodologia destinada a avaliação quantitativa do grau de deterioração de estruturas de concreto de edificações usuais. Esta foi desenvolvida e testada em diversas edificações de natureza distintas, trabalhos constante de graduação e três dissertações de mestrado (Castro, E.K., 1994; Lopes, B.A.R, 1998; e Boldo, P., 2002.) do Programa de Pós-Graduação em Estruturas e Construção Civil da Universidade de Brasília, UnB. Já tendo sido publicada em vários artigos, com a apresentação em forma sintética de resultados de sua aplicação ((Castro, Clímaco e Nepomuceno (1995); Castro e Clímaco (1999); Lopes et al (1999); Boldo e Clímaco (2002)).

A avaliação é feita mediante um programa de inspeções periódicas, com o uso deste roteiro, e tem por objetivo contribuir para a definição das ações necessárias à garantia da conservação e durabilidade da edificação nos aspectos de segurança, funcionalidade e estética, sendo estes levados em conta nas decisões de engenheiros, arquitetos e técnicos da área de manutenção e recuperação das estruturas.

No roteiro, são consideradas as disposições do texto contido na norma: Projeto de estruturas de concreto (ABNT NBR 6118:2014), referentes à durabilidade de estruturas concretadas. Além de recomendações de normas posteriores que discorrem sobre o assunto.

\section{PARÂMETROS DE INSPEÇÃO}

\subsection{Considerações Preliminares}

\subsubsection{Agressividade do ambiente}

A norma ABNT NBR 6118:2014 dispõe sobre os requisitos para a durabilidade, considerando a agressividade do meio ambiente relacionada às ações físicas e químicas que atuam sobre as estruturas de concreto, independente das ações mecânicas, das variações volumétricas de origem térmica, da retração hidráulica e outras previstas no dimensionamento das estruturas de concreto. A Tabela 1, a seguir, apresenta a classificação da agressividade do ambiente a ser considerada nos projetos de estruturas 
correntes, podendo ser avaliada simplificadamente, segundo as condições de exposição da estrutura ou de suas partes de acordo com a tabela abaixo:

Tabela 1 - Classes de agressividade ambiental (CAA) - ABNT NBR 6118:2014

\begin{tabular}{|c|l|l|l|}
\hline $\begin{array}{c}\text { Classe de } \\
\text { agressividade } \\
\text { ambiental }\end{array}$ & Agressividade & $\begin{array}{c}\text { Classificação geral do } \\
\text { tipo de ambiente para } \\
\text { efeito de projeto }\end{array}$ & $\begin{array}{c}\text { Risco de } \\
\text { deterioração } \\
\text { da estrutura }\end{array}$ \\
\hline I & Fraca & Rural - Submersa & Insignificante \\
II & Moderada & Urbana a,b \\
III & Forte & $\begin{array}{l}\text { Marinha a - Industrial a,b } \\
\text { Industrial a,c - Respingos } \\
\text { IV }\end{array}$ & $\begin{array}{l}\text { Grande } \\
\text { Elevado }\end{array}$ \\
\hline
\end{tabular}

a) Pode-se admitir um microclima com uma classe de agressividade mais branda (uma classe acima) para ambientes internos secos (salas, dormitórios, banheiros, cozinhas e áreas de serviço de apartamentos residenciais e conjuntos comerciais ou ambientes com concreto revestido com argamassa e pintura).

b) Pode-se admitir uma classe de agressividade mais branda (uma classe acima) em obras de regiões de clima seco, com umidade média relativa do ar menor ou igual a $65 \%$, partes da estrutura protegidas de chuva, em ambientes predominantemente secos ou regiões onde raramente chove.

c) Ambientes quimicamente agressivos, tanques industriais, galvanoplastia, branqueamento em indústrias de celulose e papel, armazéns de fertilizantes, indústrias químicas.

\subsection{2 - Identificação dos elementos estruturais}

A aplicação da metodologia exige representações gráficas da estrutura (plantas de forma, croquis, etc.), que permitam localizar e identificar com clareza, os elementos vistoriados, quanto à sua natureza, pavimento, tipo de ambiente, etc. É também de grande valia uma documentação fotográfica da inspeção, para auxílio do processo de avaliação de danos, diagnóstico e laudos técnicos.

\section{2 - Tipos de danos em estruturas}

Apresenta-se, a seguir, uma conceituação sucinta dos danos mais frequentes em estruturas de concreto, em ordem alfabética, visando padronizar a terminologia, e permitir, 
posteriormente, a quantificação dos danos. Cabe ressaltar a importância de se recorrer a bibliografia complementar acerca do tema, algumas das quais referenciadas neste texto.

\section{a) Carbonatação:}

Fenômeno decorrente da penetração do dióxido de carbono, $\mathrm{CO} 2$, presente na atmosfera, através das redes de poros do concreto, e de sua reação com os constituintes alcalinos da pasta de cimento, principalmente o hidróxido de cálcio.

Como consequência desse fenômeno tem-se a redução do $\mathrm{pH}$ do concreto provocando a despassivação das armaduras, em que elas se tornam susceptíveis à corrosão. Ocorrendo a partir da superfície, avançando progressivamente para o interior do concreto. Segundo o CEB/148(1982), a velocidade de carbonatação aumenta quando o ambiente possui grandes concentrações de $\mathrm{CO} 2$ (garagens, túneis etc.) e em concretos de elevada relação água/cimento $(\mathrm{a} / \mathrm{c})$ principalmente em ambientes com umidade relativa entre 50 e $70{ }^{\circ} \mathrm{C}$. Este é um dano de difícil visualização numa inspeção. Para ser detectada faz-se necessário o uso de um ensaio simples, com a aplicação de fenolftaleína com indicador na superfície recém-fraturada do concreto.

A parte do concreto carbonatada fica incolor $(\mathrm{pH}<9,3)$ e a parte não carbonatada adquire a cor vermelho-carmim. Depois de carbonatado o concreto é grande o risco de corrosão de armaduras na presença de umidade.

\section{b) Cobrimento deficiente:}

É um dano quando o cobrimento da peça de concreto não está atendendo ao cobrimento mínimo exigido pela norma de estruturas de concreto de acordo com a agressividade ambiental. A peça estrutural quando apresenta um cobrimento deficiente é mais suscetível à penetração de agentes agressivos que podem atacar as armaduras e dar início ao processo corrosivo.

A ABNT NBR 6118:2014, recomenda que o projeto e a execução devem considerar o cobrimento nominal (cnom), que é o cobrimento mínimo acrescido da tolerância de execução $(\Delta c)$. Quando houver um controle de qualidade rigoroso, pode ser adotado um valor $\Delta \mathrm{c}=5 \mathrm{~mm}$, especificando este controle nos desenhos de projeto. Em caso contrário, nas obras correntes, seu valor deve ser de, no mínimo $\Delta \mathrm{c}=10 \mathrm{~mm}$, o que determina os cobrimentos nominais indicados na Tabela 2. 
Tabela 2 - Correspondência entre a classe de agressividade ambiental e o cobrimento nominal para $\Delta \mathrm{c}=10 \mathrm{~mm}-\mathrm{ABNT}$ NBR 6118:2014

\begin{tabular}{|c|c|c|c|c|c|}
\hline \multirow{3}{*}{$\begin{array}{l}\text { Tipo de } \\
\text { estrutura }\end{array}$} & \multirow{3}{*}{$\begin{array}{l}\text { Componente } \\
\text { ou elemento }\end{array}$} & \multicolumn{4}{|c|}{ Classe de agressividade ambiental } \\
\hline & & $\mathrm{I}$ & II & III & IV $c$ \\
\hline & & \multicolumn{4}{|c|}{ Cobrimento nominal (mm) } \\
\hline \multirow{3}{*}{$\begin{array}{l}\text { Concreto } \\
\text { armado }\end{array}$} & Laje $b$ & 20 & 25 & 35 & 45 \\
\hline & Viga/pilar & 25 & 30 & 40 & 50 \\
\hline & $\begin{array}{l}\text { Elementos } \\
\text { estruturais } \\
\text { em contato } \\
\text { com o solo } d\end{array}$ & \multicolumn{2}{|c|}{30} & 40 & 50 \\
\hline \multirow{2}{*}{$\begin{array}{c}\text { Concreto } \\
\text { protendido } a\end{array}$} & Laje & 25 & 30 & 40 & 50 \\
\hline & Viga/pilar & 30 & 35 & 45 & 55 \\
\hline
\end{tabular}

a) Cobrimento nominal da bainha ou dos fios, cabos e cordoalhas. O cobrimento da armadura passiva deve respeitar os cobrimentos para concreto armado.

b) Para a face superior de lajes e vigas que serão revestidas com argamassa de contrapiso, revestimento finais secos tipo carpete e madeira, argamassa de cerâmicos, pisos asfálticos e outros, as exigências desta tabela podem ser revestimento e acabamento, como pisos de elevado desempenho, pisos substituídas pelas de 7.4.7.5, respeitado um cobrimento nominal $\geq 15 \mathrm{~mm}$.

c) Nas superfícies expostas a ambientes agressivos, como reservatórios, estações de tratamento de água e esgoto, condutos de esgotos, canaletas de efluentes e outras obram em ambientes químicos e intensamente agressivos, devem ser atendidos os cobrimentos da classe de agressividade IV.

d) No trecho dos pilares em contato com o solo junto aos elementos de fundação, a armadura deve ter cobrimento nominal $\geq 45 \mathrm{~mm}$.

Segundo a norma, os cobrimentos nominais e mínimos são sempre referidos à superfície da armadura externa, em geral a face externa do estribo. O cobrimento nominal de uma determinada barra deve sempre ser:

cnom $\geq \Phi$ barra

cnom $\geq \Phi$ feixe $=\Phi^{n}=\Phi^{n^{1 / 2}}$

cnom $\geq 0,5 \Phi$ bainha 
Ainda segundo a norma, em se tratando de elementos estruturais pré-fabricados, os valores de cobrimento mínimo das armaduras devem seguir o disposto na ABNT NBR 9062:2001.

\section{c) Contaminação por cloretos:}

A contaminação do concreto por cloretos pode ser causada pelo emprego de aditivos à base de cloretos na execução do concreto, principalmente em peças pré-moldadas; pela penetração de cloretos presentes no meio ambiente (como no caso de regiões à beira-mar); pelo uso de sais de degelo usados em climas frios; e água ou agregados contaminados. Também podem ser introduzidos no concreto pelo uso de produtos de limpeza de pisos e fachadas, que contenham cloretos como soluções de $\mathrm{HCl}$ em baixas concentrações (ácido muriático) e qualquer ambiente contaminado por cloretos, como caixas d'água (especialmente o fundo da laje da tampa), locais de armazenamento de produtos à base de cloretos, etc.

O principal dano que provoca nas estruturas de concreto armado ou protendido é a corrosão das armaduras. As manifestações mais comuns são as fissuras, sobre as armaduras, quando a corrosão já está em estado mais avançado e a presença de manchas no concreto devido à retenção de umidade, frequentemente com a criação de fungos.

Existe um valor limite de concentração de íons cloreto para que se possa iniciar o processo de corrosão das armaduras, sendo mais favorável em ambientes úmidos, uma vez que a água presente nos poros facilita o transporte de cloretos por difusão.

De acordo com o ACI 318-21 (2001) o conteúdo máximo de cloretos com relação à massa de cimento deve ser $\leq 0,15 \%$ em ambientes com cloretos, $\leq 0,3 \%$ em ambientes normal, $\leq$ $1 \%$ em ambiente seco e $\leq 0,06 \%$ para concreto protendido.

\section{d) Corrosão de armaduras:}

A corrosão é um processo físico-químico gerador de óxidos e hidróxidos de ferro, produtos que ocupam um volume significativamente superior (em até 6 vezes) ao volume corroído das armaduras, provocando no concreto elevadas tensões de tração (de até $15 \mathrm{MPa}$ ). Essas tensões ocasionam a fissuração e o posterior desplacamento do cobrimento do concreto (Cánovas, 1988). No início, a corrosão pode se manifestar com o aparecimento de manchas marrom, avermelhada ou esverdeada na superfície do elemento estrutural, devido à lixiviação dos produtos de corrosão. Com o passar do tempo, a sua evolução pode chegar até à perda total da seção da armadura. 
Além dos danos ao concreto e da redução da capacidade resistente da armadura, a corrosão provoca a perda de aderência entre o aço e o concreto, reduzindo a ductilidade da armadura.

\section{e) Desagregação:}

Separação física de partes de concreto ou dos agregados, principalmente graúdos, com perda de monolitismo e, na maioria das vezes, perda da capacidade aglomerante entre a pasta e os agregados. É um fenômeno característico de ataques químicos do concreto, que envolve formas diversas: reação álcali-agregado, reações expansivas com sulfatos, ataques ácidos e também por ações biológicas (micro-organismos). Quando existe a suspeita desses ataques químicos é requerida uma inspeção mais detalhada da sua extensão e causa.

\section{f) Deslocamentos por empuxo:}

Deslocamento de peças estruturais devido ao empuxo de terra, em especial sobre paredes de contenção, proveniente da pressão ativa exercida por um maciço não coesivo, sobre um anteparo vertical. As cortinas devem ser providas de drenos, para evitar o acúmulo de água entre o terrapleno e a mesma, que resultaria em acréscimo do empuxo hidrostático. Além disso, o deslocamento pode ser causado pela saturação do maciço, podendo ainda, ser agravado pela passagem de veículos.

\section{g) Desplacamento:}

Ocorrência de lascas ou escamas que se destacam do concreto não resultantes de ataque químico no concreto, e sim, devido a um ou mais fatores como choques, movimentações térmicas, pressão ou expansão das armaduras no interior do concreto (corrosão).

\section{h) Desvios de geometria:}

Perda de alinhamento de elementos estruturais com relação ao seu eixo, produzindo excentricidade de carga. Pode ter como causas: deficiências na execução por movimentação ou incorreção de formas, ou movimentação da estrutura, por esforços não considerados corretamente ou imprevistos.

\section{i) Eflorescência:}

De maneira geral, trata-se de uma manifestação da dissolução dos produtos de hidratação do cimento presentes no interior do concreto, principalmente os hidróxidos de sódio e potássio, e em água (especialmente a água pura e branda) que são transportados para o exterior (lixiviação). 
Os produtos alcalinos e o hidróxido de cálcio que se depositam sobre a superfície do concreto, na presença do $\mathrm{CO} 2$ do ambiente, são carbonatados, formando carbonatos, um produto insolúvel e esbranquiçado, podendo inclusive formar estalactite se a água for abundante. Se a água não for abundante e a pressão for pequena, os produtos carbonatados podem inclusive colmatar possíveis fissuras ou falhas por onde a água migra. Quando existe a possibilidade da água presente conter algum tipo de ácido que ataque os produtos hidratados (silicatos e aluminatos hidratados) do cimento, deve-se fazer uma avaliação mais detalhada.

\section{j) Falha de concretagem (nichos ou ninhos de concreto):}

Deficiência na concretagem da peça com exposição de agregados, devido a um ou mais fatores, como a dosagem inadequada, diâmetro máximo do agregado graúdo não condizente com as dimensões da peça, lançamento e/ou adensamento inadequados, taxas excessivas e espaçamento inadequado de armaduras e perda de nata de cimento por aberturas nas formas. Podem ocorrer situações em que não somente os agregados ficam expostos, como a possibilidade de exposição das armaduras dos elementos estruturais, nesse caso pode-se iniciar o processo corrosivo.

\section{k) Fissuração inaceitável:}

A norma ABNT NBR 6118:2014 dispõe que a fissuração é nociva quando há abertura das fissuras na superfície do concreto. A abertura máxima característica wk* das fissuras, desde que não exceda valores da ordem de $0,2 \mathrm{~mm}$ a $0,4 \mathrm{~mm}$ para o concreto armado, conforme a Tabela 3:

Tabela 3 - Exigências de durabilidade relacionadas à fissuração e à proteção da armadura, em função das classes de agressividade ambiental - ABNT NBR 6118:2014

\begin{tabular}{|c|c|c|c|}
\hline $\begin{array}{c}\text { Tipo de concreto } \\
\text { estrutural }\end{array}$ & $\begin{array}{c}\text { Classe de } \\
\text { agressividade } \\
\text { ambiental (CAA) e o } \\
\text { tipo de protensão }\end{array}$ & $\begin{array}{l}\text { Exigências } \\
\text { relativas à } \\
\text { fissuração }\end{array}$ & $\begin{array}{c}\text { Combinação de } \\
\text { ações em serviço a } \\
\text { utilizar }\end{array}$ \\
\hline Concreto Simples & CAA I a CAA IV & Não há & - \\
\hline \multirow[t]{3}{*}{ Concreto armado } & CAA I & $\begin{array}{l}\text { ELS }-\mathrm{W} \text { wk } \leq 0,4 \\
\mathrm{~mm}\end{array}$ & \multirow[t]{3}{*}{ Combinação frequente } \\
\hline & CAA II e CAA III & $\begin{array}{l}\mathrm{ELS}-\mathrm{W} \text { wk } \leq 0,3 \\
\mathrm{~mm}\end{array}$ & \\
\hline & CAA IV & ELS $-\mathrm{W}$ wk $\leq 0,2$ & \\
\hline
\end{tabular}




\begin{tabular}{|c|c|c|c|}
\hline & & $\mathrm{mm}$ & \\
\hline $\begin{array}{l}\text { Concreto } \\
\text { protendido nível } 1 \\
\text { (protensão parcial) }\end{array}$ & $\begin{array}{l}\text { Pré-tração com CAA I } \\
\text { ou Pós- tração com } \\
\text { CAA I e CAA II }\end{array}$ & $\begin{array}{l}\mathrm{ELS}-\mathrm{W} \text { wk } \leq 0,2 \\
\mathrm{~mm}\end{array}$ & Combinação frequente \\
\hline \multirow{3}{*}{$\begin{array}{l}\text { Concreto } \\
\text { protendido nível } 2 \\
\text { (protensão } \\
\text { limitada) }\end{array}$} & \multirow{3}{*}{$\begin{array}{l}\text { Pré-tração com CAA II } \\
\text { ou Pós- tração com } \\
\text { CAA III e CAA IV }\end{array}$} & \multicolumn{2}{|c|}{ Verificar as duas condições abaixo } \\
\hline & & ELS - F & Combinação frequente \\
\hline & & $E L S-D$ a & $\begin{array}{l}\text { Combinação quase } \\
\text { permanente }\end{array}$ \\
\hline \multirow{3}{*}{$\begin{array}{l}\text { Concreto } \\
\text { protendido nível } 3 \\
\text { (protensão } \\
\text { completa) }\end{array}$} & \multirow{3}{*}{$\begin{array}{l}\text { Pré-tração com CAA III } \\
\text { e IV }\end{array}$} & \multicolumn{2}{|c|}{ Verificar as duas condições abaixo } \\
\hline & & ELS - F & Combinação rara \\
\hline & & $\mathrm{ELS}-\mathrm{D}$ a & Combinação frequente \\
\hline \multicolumn{4}{|c|}{$\begin{array}{l}\text { a) A critério do projetista, o ELS - D pode ser substituído pelo ELS - DP com ap = } 50 \\
\text { mm (Figura 3.1) }\end{array}$} \\
\hline \multicolumn{4}{|l|}{ NOTAS } \\
\hline \multicolumn{4}{|c|}{ 1) As definições de ELS - W, ELS - F e ELS - D encontra-se em 3.2. } \\
\hline 2) $\mathrm{P}$ & $\begin{array}{l}\text { ses de agressividade am } \\
\text { o aderentes tenham proteç }\end{array}$ & $\begin{array}{l}\text { biental CAA - III } \\
\text { ão especial na região }\end{array}$ & $\begin{array}{l}\text { IV, exige-se que as } \\
\text { le suas ancoragens. }\end{array}$ \\
\hline $\begin{array}{l}\text { 3) No projeto de } \\
\text { combinação } \mathrm{f}\end{array}$ & $\begin{array}{l}\text { lajes lisas e cogumelo pro } \\
\text { requente das ações, em toc }\end{array}$ & $\begin{array}{l}\text { tendidas, basta ser ate } \\
\text { las as classes de agres }\end{array}$ & $\begin{array}{l}\text { ndido o ELS - F para a } \\
\text { ividade ambiental. }\end{array}$ \\
\hline
\end{tabular}

Somente deve-se considerar nesse dano, o surgimento de fissuras relacionadas ao estado fresco e endurecido do concreto e fissuras oriundas de cargas impostas.

Portanto, aqui, as fissuras de ataque químico responsáveis por desagregação e corrosão devem ser desconsideradas.

* $w \mathrm{k}$ - Abertura característica de fissuras na superfície do concreto.

\section{1) Flechas excessivas:}

A norma ABNT NBR 6118:2014 apresenta, dentre outros, os limites de deslocamento de peças estruturais, e o que eles podem causar nas estruturas dividindo em 4 grupos básicos ao que se refere à e mostrados na Tabela 4.

1) Aceitabilidade sensorial - podem causar vibrações indesejáveis ou efeito visual desagradável;

2) Efeitos específicos - podem impedir a utilização adequada da estrutura; 
3) Efeitos em elementos não estruturais - podem ocasionar defeito em elementos que não fazem parte da estrutura, mas estão ligados a ela;

4) Efeitos em elementos estruturais - podem afetar as peças estruturais provocando afastamentos em relação às hipóteses de cálculos adotadas.

Tabela 4 - Limites para deslocamentos - ABNT NBR 6118:2014

\begin{tabular}{|c|c|c|c|c|}
\hline Tipo de efeito & $\begin{array}{ll}\text { Razão } & \text { da } \\
\text { limitação } & \end{array}$ & Exemplo & $\begin{array}{l}\text { Deslocamento } \\
\text { a considerar }\end{array}$ & $\begin{array}{l}\text { Deslocamento- } \\
\text { limite }\end{array}$ \\
\hline \multirow[t]{2}{*}{$\begin{array}{l}\text { Aceitabilidade } \\
\text { sensorial }\end{array}$} & Visual & \begin{tabular}{l}
\multicolumn{2}{c}{ Deslocamentos } \\
visíveis em \\
elementos \\
estruturais
\end{tabular} & Total & $1 / 250$ \\
\hline & Outro & $\begin{array}{l}\text { Vibrações } \\
\text { sentidas no piso }\end{array}$ & $\begin{array}{l}\text { Devido } \\
\text { cargas } \\
\text { acidentais }\end{array}$ & $1 / 350$ \\
\hline \multirow[t]{4}{*}{$\begin{array}{l}\text { Efeitos } \\
\text { estruturais em } \\
\text { serviço }\end{array}$} & $\begin{array}{l}\text { Superfícies que } \\
\text { devem drenar } \\
\text { água }\end{array}$ & $\begin{array}{l}\text { Coberturas } \mathrm{e} \\
\text { varandas }\end{array}$ & Total & $1 / 250 \mathrm{a}$ \\
\hline & \multirow{2}{*}{$\begin{array}{l}\text { Pavimentos } \\
\text { que devem } \\
\text { permanecer } \\
\text { planos }\end{array}$} & \multirow{2}{*}{$\begin{array}{lr}\text { Ginásios } & \mathrm{e} \\
\text { pistas } & \mathrm{de} \\
\text { boliche } & \end{array}$} & Total & $\begin{array}{l}1 / 350+ \\
\text { contraflecha } b\end{array}$ \\
\hline & & & $\begin{array}{l}\text { Ocorrido após } \\
\text { a construção do } \\
\text { piso }\end{array}$ & $1 / 600$ \\
\hline & $\begin{array}{l}\text { Elementos que } \\
\text { suportam } \\
\text { equipamentos } \\
\text { sensíveis }\end{array}$ & Laboratórios & $\begin{array}{l}\text { Ocorrido após } \\
\text { nivelamento do } \\
\text { equipamento }\end{array}$ & $\begin{array}{l}\text { De acordo com } \\
\text { recomendação do } \\
\text { fabricante do } \\
\text { equipamento }\end{array}$ \\
\hline \multirow[b]{3}{*}{ Efeitos em } & & $\begin{array}{l}\text { Alvenaria, } \\
\text { caixilhos e } \\
\text { revestimentos. }\end{array}$ & $\begin{array}{lr}\text { Após } & \text { a } \\
\text { construção da } & \text { parede }\end{array}$ & $\begin{array}{l}1 / 500 \text { c e } 10 \mathrm{~mm} \mathrm{e} \\
\Phi=0,0017 \mathrm{rad} d\end{array}$ \\
\hline & & $\begin{array}{l}\text { Divisórias leves } \\
\text { e caixilhos } \\
\text { telescópicos }\end{array}$ & $\begin{array}{l}\text { Ocorrido após } \\
\text { a instalação da } \\
\text { divisória }\end{array}$ & $1 / 250 c$ e $25 \mathrm{~mm}$ \\
\hline & & Movimento & Provocado pela & $\mathrm{H} / 1700$ e $\mathrm{Hi} / 850$ \\
\hline
\end{tabular}




\begin{tabular}{|c|c|c|c|c|}
\hline \multirow[t]{2}{*}{$\begin{array}{l}\text { elementos não } \\
\text { estruturais }\end{array}$} & \multirow[t]{2}{*}{ Paredes } & $\begin{array}{l}\text { lateral } \\
\text { edifícios }\end{array}$ & $\begin{array}{l}\text { ação do vento } \\
\text { para } \\
\text { combinação } \\
\text { frequente ( } \psi= \\
0,30)\end{array}$ & $\begin{array}{l}e \quad \text { entre } \\
\text { pavimentos } f\end{array}$ \\
\hline & & $\begin{array}{l}\text { Movimentos } \\
\text { térmicos } \\
\text { verticais }\end{array}$ & $\begin{array}{l}\text { Provocado por } \\
\text { diferença de } \\
\text { temperatura }\end{array}$ & $1 / 400 \mathrm{~g}$ e $15 \mathrm{~mm}$ \\
\hline \multirow{4}{*}{$\begin{array}{ll}\text { Efeitos em } & \text { em } \\
\text { elementos não } \\
\text { estruturais }\end{array}$} & \multirow{3}{*}{ Forros } & $\begin{array}{l}\text { Movimentos } \\
\text { térmicos } \\
\text { horizontais }\end{array}$ & $\begin{array}{l}\text { Provocado por } \\
\text { diferença de } \\
\text { temperatura }\end{array}$ & $\mathrm{Hi} / 500$ \\
\hline & & $\begin{array}{l}\text { Revestimentos } \\
\text { colados }\end{array}$ & $\begin{array}{l}\text { Ocorrido após } \\
\text { a construção do } \\
\text { forro }\end{array}$ & $1 / 350$ \\
\hline & & $\begin{array}{l}\text { Revestimentos } \\
\text { pendurados ou } \\
\text { com juntas }\end{array}$ & $\begin{array}{l}\text { Deslocamento } \\
\text { ocorrido após a } \\
\text { construção do } \\
\text { forro }\end{array}$ & $1 / 175$ \\
\hline & Pontes rolantes & $\begin{array}{l}\text { Desalinhamento } \\
\text { de trilhos }\end{array}$ & $\begin{array}{l}\text { Deslocamento } \\
\text { provocado } \\
\text { pelas ações } \\
\text { decorrentes da } \\
\text { frenação }\end{array}$ & $\mathrm{Hi} / 400$ \\
\hline $\begin{array}{l}\text { Efeitos em } \\
\text { elementos } \\
\text { estruturais }\end{array}$ & $\begin{array}{l}\text { Afastamento } \\
\text { em relação às } \\
\text { hipóteses de } \\
\text { cálculo } \\
\text { adotadas }\end{array}$ & \multicolumn{3}{|c|}{$\begin{array}{l}\text { Se os deslocamentos forem relevantes para o elemento } \\
\text { considerado, seus efeitos sobre as tensões ou sobre a } \\
\text { estabilidade da estrutura devem ser considerados } \\
\text { incorporando-os ao modelo estrutural adotado. }\end{array}$} \\
\hline \multicolumn{5}{|c|}{$\begin{array}{l}\text { a) As superfícies devem ser suficientemente inclinadas ou o deslocamento previsto } \\
\text { compensando por contraflechas, de modo a não se ter acúmulo de água. } \\
\text { b) Os deslocamentos podem ser parcialmente pela especificação de contraflechas. } \\
\text { Entretanto, a atuação isolada da contraflecha não pode ocasionar um desvio maior }\end{array}$} \\
\hline
\end{tabular}


c) O vão 1 deve ser tomado na direção na qual a parede ou divisória se desenvolve.

d) Rotação nos elementos que suportam paredes.

e) H é altura total do edifício e Hi o desnível entre os dois pavimentos vizinhos.

f) Esse limite aplica-se ao deslocamento lateral entre os dois pavimentos consecutivos, devido à atuação de ações horizontais. Não podem ser incluídos os deslocamentos devidos a deformações axiais nos pilares. O limite também se aplica ao deslocamento vertical relativo das extremidades, lintéis, conectados a duas paredes de contraventamento, quando Hi representa o comprimento lintel.

g) O valor 1 refere-se à distância entre o pilar externo e o primeiro pilar interno.

NOTAS

1) Todos os valores-limites de deslocamentos supõem elementos de vão 1 suportados em ambas extremidades por apoios que não se movem. Quando se trata de balanços, o vão equivalente a ser considerado deve ser o dobro do comprimento do balanço.

2) Para o caso de elementos de superfície, os limites prescritos consideram que o valor lé o menor vão, exceto em casos de verificação de paredes e divisória, onde interessa a direção na qual a parede ou divisória se desenvolve, limitando-se esse valor a duas vezes o vão menor.

3) O deslocamento total deve ser obtido a partir da combinação das ações características ponderadas pelos os coeficientes definidos na seção 11 .

4) Deslocamentos excessivos podem ser parcialmente compensados por contraflechas.

\section{m) Impermeabilização deficiente:}

A impermeabilização pode ser definida como um sistema de vedação constituído por materiais rígidos, plásticos ou elásticos, com a finalidade de impedir a penetração de umidade ou líquidos no concreto. No caso de reservatórios e cortinas, deve ser projetada para resistir às pressões hidrostáticas, o que não é necessário para as lajes de cobertura, terraços, calhas, onde não ocorre este tipo de pressão.

Os danos podem ser causados por ações mecânicas, previsão incorreta de movimentos da estrutura e perda de elasticidade dos materiais utilizados. 


\section{n) Manchas:}

Ocorrência de manchas escuras no concreto, devido à contaminação por fungos, mofo, etc., principalmente nas fachadas expostas. Outras manchas como as relacionadas à corrosão e eflorescências, não devem ser consideradas.

\section{o) Obstrução de juntas de dilatação:}

A junta de dilatação é uma separação física entre duas partes de uma estrutura, para que estas partes possam se movimentar sem transmissão de esforço entre elas. A presença de material rígido ou de material de preenchimento que tenha perdido a sua elasticidade, produz tensões indesejáveis na estrutura, podendo ocasionar fissuras nas lajes adjacentes à junta, com a possibilidade de se propagar às vigas e pilares próximos. Os sistemas de vedação/enchimento das juntas devem acomodar a amplitude do movimento da mesma.

\section{p) Recalque:}

O recalque provoca movimentação na estrutura que, conforme o seu tipo, pode ser afetada pelo assentamento total máximo (recalque uniforme), pela inclinação uniforme (desaprumo) ou pelos assentamentos diferenciais (recalques diferenciais e distorções angulares).

Os recalques distorcionais das fundações, inadmissíveis estruturalmente, ocorrem por deformações excessivas e podem ser causados por um ou mais dos seguintes fatores de risco: ausência, insuficiência ou má qualidade das investigações geotécnicas; má interpretação dos resultados da investigação geotécnica; avaliação errônea dos valores dos esforços provenientes da estrutura (sub-dimensionamento); adoção inadequada da tensão admissível do solo ou da cota de apoio das fundações; modelos inconvenientes de cálculo das fundações; cálculo estrutural incorreto; influências externas (escavações ou deslizamentos não previsíveis, agressividade ambiental, enchentes, construções vizinhas, descalçamento das fundações por escavações vizinhas); colapso do solo (por exemplo, devido à ruptura de tubulações subterrâneas ou vazamentos em reservatórios subterrâneos); alteração do nível do lençol freático; modificação no carregamento devido à mudança de utilização da estrutura (acréscimos ou ampliação de áreas), efeito piscina (entupimento de drenos), sobrecargas não previstas; cargas dinâmicas (vibrações, tremores de terra, etc.) e por fim, falha de manutenção em obras críticas.

\section{q) Sinais de esmagamento do concreto:}

Início do processo de desintegração do concreto. No caso de pilares, caracteriza-se pelo aparecimento de fissuras diagonais. É causado por sobrecargas excessivas ou 
movimentação da estrutura, podendo evoluir para um intenso lascamento do concreto, com perda de seção e flambagem das armaduras.

\section{r) Umidade:}

Penetração de águas, agressivas ou não, em peças estruturais, através de fissuras, ninhos de concretagem, juntas de concretagem mal executadas ou devido à alta porosidade do concreto. Pode ainda, ter origem em danos na impermeabilização, deficiências no escoamento de águas pluviais, vazamento em tubulações, etc.

Esse dano pode favorecer fatores como o aparecimento da corrosão; a lixiviação; e danos nos demais elementos da edificação.

\section{s) Umidade na base:}

A presença de umidade na base de pilares e/ou blocos de fundação, pela sua gravidade, deve ser tratada como dano específico. Podem ser proveniente de deficiência no escoamento de águas pluviais, vazamento em tubulações, vazamento em reservatórios enterrados, etc. A presença de umidade pode favorecer o aparecimento de recalques. 


\section{ROTEIRO DE INSPEÇÃO (FONSECA, 2007) \\ ANEXO B: PLANILHAS PARA INSPEÇÃO ROTINEIRA \\ PARA ESTRUTURAS DE CONCRETO}

FICHA CADASTRO DA EDIFICAÇÃO

Nome:

Localização:

Natureza do Uso:

Área construída aproximada:

Idade:

Número de pavimentos:

Sistema Construtivo:

Classes de Agressividade do meio Ambiente/ condições de Exposições, NBR 6118:2014:

Observações:

Data da (s) Inspeções:

Responsável (is) pela Inspeção:

Nome(s):

Cargo/ Função:

Empresa / órgão: 
Tabela B.1 - Classificação dos danos e fatores de intensidade (Fi) da metodologia GDE/UnB - Fonseca (2007)

\begin{tabular}{|c|c|}
\hline Tipos de Danos & Fator de Intensidade do dano (Fi) - Tipos de Manifestação \\
\hline Carbonatação & $\begin{array}{l}1 \text { - Localizada, com algumas regiões com } \mathrm{pH}<9 \text {, sem atingir a } \\
\text { armadura; } \\
2 \text { - Localizada, atingindo a armadura, em ambientes seco; } \\
3 \text { - Localizada, atingindo a armadura, em ambiente úmido; } \\
4 \text { - Generalizada, atingindo a armadura em ambientes úmidos. }\end{array}$ \\
\hline $\begin{array}{c}\text { Cobrimento } \\
\text { Deficiente }\end{array}$ & $\begin{array}{l}\text { 1- Menores que os previstos em norma sem, no entanto, permitir a } \\
\text { localização da armadura; } \\
2 \text { - Menor que o previsto em norma, permitindo a localização visual } \\
\text { da armadura ou armadura exposta em pequenas extensões; } \\
3 \text { - Deficiente, com armaduras expostas em extensões significativas. }\end{array}$ \\
\hline $\begin{array}{c}\text { Contaminação } \\
\text { por Cloretos }\end{array}$ & $\begin{array}{l}2 \text { - Em elementos no interior sem umidade; } \\
3 \text { - Em elementos no exterior sem umidade; } \\
4 \text { - Em ambientes úmidos. }\end{array}$ \\
\hline $\begin{array}{l}\text { Corrosão de } \\
\text { Armaduras }\end{array}$ & $\begin{array}{l}2 \text { - Manifestações leves, pequenas manchas; } \\
3 \text { - Grandes manchas e / ou fissuras de corrosão; } \\
4 \text { - Corrosão acentuada na armadura principal, c/ perda relevante de } \\
\text { seção. }\end{array}$ \\
\hline Desagregação & $\begin{array}{l}2 \text { - Início de manifestação; } \\
3 \text { - Manifestações leves, início de estofamento do concreto; } \\
4 \text { - Por perda acentuada da seção e esfarelamento do concreto. }\end{array}$ \\
\hline $\begin{array}{c}\text { Deslocamento } \\
\text { por empuxo }\end{array}$ & $\begin{array}{l}3 \text { - Deslocamento lateral da cortina no sentido horizontal, estável; } \\
4 \text { - Deslocamento lateral da cortina no sentido horizontal, instável. }\end{array}$ \\
\hline $\begin{array}{c}\text { Esfoliação/ } \\
\text { Desplacamento }\end{array}$ & $\begin{array}{l}2 \text { - Pequenas escamações do concreto; } \\
3 \text { - Lascamento de grandes proporções, com exposição da armadura; } \\
4 \text { - Lascamento acentuado com perda relevante da seção. }\end{array}$ \\
\hline $\begin{array}{l}\text { Desvios de } \\
\text { Geometria }\end{array}$ & $\begin{array}{l}2 \text { - Pilares e cortinas com excentricidade } \leq \mathrm{h} / 100 \text { (h=altura); } \\
3 \text { - Pilares e cortinas com excentricidades } \mathrm{h} / 100 \leq \mathrm{e}<\mathrm{h} / 50 \text {; } \\
4 \text { - Pilares e cortinas com excentricidades } \geq \mathrm{h} / 50 \text {. }\end{array}$ \\
\hline Eflorescência & $\begin{array}{l}1 \text { - Início de manifestações; } \\
2 \text { - Manchas de pequenas dimensões; } \\
3 \text { - Manchas acentuadas, em grandes extensões; } \\
4 \text { - Grandes formações de crostas de carbonato de cálcio }\end{array}$ \\
\hline
\end{tabular}




\begin{tabular}{|c|c|}
\hline & (estalactites). \\
\hline $\begin{array}{c}\text { Falhas de } \\
\text { Concretagem }\end{array}$ & $\begin{array}{l}1 \text { - Superficial e pouco significativa em relação às dimensões da } \\
\text { peça; } \\
2 \text { - Significante em relação às dimensões da peça; } \\
3 \text { - Profunda em relação às dimensões da peça, com ampla } \\
\text { exposição da armadura; } \\
4 \text { - Perda relevante da seção da peça. }\end{array}$ \\
\hline Fissuras & $\begin{array}{l}1 \text { - Aberturas menores do que as máximas previstas em norma; } \\
2 \text { - Estabilizadas, com abertura até } 40 \% \text { acima dos limites de norma; } \\
3 \text { - Aberturas excessivas; estabilizadas; } \\
4 \text { - Aberturas excessivas; não estabilizadas. }\end{array}$ \\
\hline Flechas & $\begin{array}{l}1 \text { - Não perceptíveis a olho nu; } \\
2 \text { - Perceptíveis a olho nu, dentro dos limites previstos na norma; } \\
3 \text { - Superiores em até } 40 \% \text { às previstas na norma; } \\
4 \text { - Excessivas. }\end{array}$ \\
\hline $\begin{array}{l}\text { Impermeabiliz } \\
\text { ação deficiente }\end{array}$ & $\begin{array}{l}2 \text { - Danos na camada protetora e/ou perda de elasticidade do } \\
\text { material da impermeabilização; } \\
3 \text { - Descontinuada, degradada em alguns pontos (pontos de } \\
\text { infiltrações); } \\
4 \text { - Degradação acentuada, com perda relevante da estanqueidade. }\end{array}$ \\
\hline Manchas & $\begin{array}{l}2 \text { - Manchas escuras de pouca extensão, porém significativas }(<50 \% \\
\text { da área visível do elemento estrutural); } \\
3 \text { - Manchas escuras de grande extensão (>50\%); } \\
4 \text { - Manchas escuras em todo o elemento estrutural (100\%). }\end{array}$ \\
\hline $\begin{array}{c}\text { Obstrução de } \\
\text { juntas de } \\
\text { dilatação }\end{array}$ & $\begin{array}{l}2 \text { - Perda de elasticidade do material da junta; início de fissuras } \\
\text { paralelas às juntas nas lajes adjacentes; } \\
3 \text { - Presença de material não compressível na junta; grande } \\
\text { incidência de fissuras paralelas às juntas nas lajes adjacentes; } \\
4 \text { - Fissuras em lajes adjacentes às juntas, com prolongamento er } \\
\text { vigas e /ou pilares de suporte. }\end{array}$ \\
\hline Recalques & $\begin{array}{l}2 \text { - Indícios de recalque pelas características das trincas na alvenaria; } \\
3 \text { - Recalque estabilizado com fissuras em peças estruturais; }\end{array}$ \\
\hline
\end{tabular}




\begin{tabular}{|c|l|}
\hline \multirow{2}{*}{$\begin{array}{c}\text { Sinais de } \\
\text { esmagamento } \\
\text { do concreto }\end{array}$} & $\begin{array}{l}3 \text { - Desintegrações do concreto na extremidade superior do pilar, } \\
\text { causada por sobrecarga ou movimentação da estrutura; fissuras } \\
\text { diagonais isoladas; } \\
4 \text { - Fissuras de cisalhamento bidiagonias, com intenso lascamento } \\
\text { e/ou esmagamento do concreto devido ao cisalhamento e a a } \\
\text { compressão, com perda substancial de material; deformação residual } \\
\text { aparente; exposição e início de flambagem de barras de armadura. }\end{array}$ \\
\hline Umidade & $\begin{array}{l}1 \text { - Indícios de umidade; } \\
2 \text { - Pequenas manchas; } \\
3 \text { - Grandes manchas; } \\
4 \text { - Generalizada. }\end{array}$ \\
\hline Umidade na & $\begin{array}{l}\text { comprometer as fundações; } \\
4 \text { - Vazamentos em tubulações enterradas causando erosão aparente } \\
\text { junto às fundações. }\end{array}$ \\
\hline
\end{tabular}


Tabela B.2 - Famílias de elementos estruturais - Fonseca (2007)

\begin{tabular}{|l|c|c|c|c|}
\hline \multicolumn{3}{|c|}{ PILARES } \\
\hline Nome do Elemento: Pilares & \multicolumn{2}{c|}{ Data da vistoria: } \\
\hline \multicolumn{1}{|c|}{ Lanos } & \multicolumn{2}{|c|}{ Realizada por: } \\
\hline Carbonatação & Fp & Fi & D & \multicolumn{1}{|c|}{ Croquis/ Observações } \\
\hline Cobrimento deficiente & 3 & & & \multirow{2}{*}{} \\
\hline Contaminação por cloretos & 3 & & & \\
\hline Corrosão de armaduras & 4 & & & \\
\hline Desagregação & 5 & & & \\
\hline Desplacamento & 3 & & & \\
\hline Desvio de geometria & 3 & & & \\
\hline Eflorescência & 4 & & & \\
\hline Falha de concretagem & 2 & & & \\
\hline Fissuras & 3 & & & \\
\hline Manchas & 2 a $5^{*}$ & & & \\
\hline Recalque & 3 & & & \\
\hline Sinais de esmagamento & 5 & & & \\
\hline Umidade na base & 5 & & & \\
\hline
\end{tabular}

\begin{tabular}{|c|c|c|c|c|}
\hline \multicolumn{5}{|c|}{ VIGAS } \\
\hline Nome do Elemento: Vigas & \multicolumn{4}{|c|}{ Data da vistoria: } \\
\hline Local: & \multicolumn{4}{|c|}{ Realizada por: } \\
\hline Danos & Fp & $\mathbf{F i}$ & $\mathbf{D}$ & Croquis/ Observações \\
\hline Carbonatação & 3 & & & \\
\hline Cobrimento deficiente & 3 & & & \\
\hline Contaminação por cloretos & 4 & & & \\
\hline Corrosão de armaduras & 5 & & & \\
\hline Desagregação & 3 & & & \\
\hline Desplacamento & 3 & & & \\
\hline Eflorescência & 2 & & & \\
\hline Falhas de concretagem & 2 & & & \\
\hline Fissuras & 2 a $5 *$ & & & \\
\hline Manchas & 3 & & & \\
\hline Flechas & 5 & & & \\
\hline Sinais de esmagamento & 4 & & & \\
\hline Umidade & 3 & & & \\
\hline
\end{tabular}




\begin{tabular}{|c|c|c|c|c|}
\hline \multicolumn{5}{|c|}{ LAJES } \\
\hline \multirow{3}{*}{$\begin{array}{l}\text { Nome do Elemento: Lajes } \\
\text { Local: } \quad \text { Danos }\end{array}$} & \multicolumn{4}{|c|}{ Data da vistoria: } \\
\hline & Realizad & da & por & \\
\hline & \begin{tabular}{|l|l} 
Fp & 1 \\
\end{tabular} & $\mathbf{F i}$ & D & Croquis/ Observações \\
\hline Carbonatação & 3 & & & \\
\hline Cobrimento deficiente & 3 & & & \\
\hline Contaminação por cloretos & 3 & & & \\
\hline Corrosão de armaduras & 5 & & & \\
\hline Desagregação & 3 & & & \\
\hline Desplacamento & 3 & & & \\
\hline Eflorescência & 2 & & & \\
\hline Falhas de concretagem & 2 & & & \\
\hline Fissuras & 2 a $5^{*}$ & & & \\
\hline Manchas & 3 & & & \\
\hline Flechas & 5 & & & \\
\hline Sinais de esmagamento & 3 & & & \\
\hline Umidade & 3 & & & \\
\hline
\end{tabular}

\begin{tabular}{|c|c|c|c|}
\hline \multicolumn{4}{|c|}{ JUNTAS DE DILATAÇÃO } \\
\hline Nome do Elemento: & Data da & vis & \\
\hline Local: & Realiza & $\mathrm{da}_{1}$ & \\
\hline Danos & \begin{tabular}{|l|l|} 
Fp & $\mathbf{F i}$ \\
\end{tabular} & $\mathbf{D}$ & Croquis/ Observações \\
\hline Obstrução de juntas & \begin{tabular}{|l|l|}
5 & \\
\end{tabular} & & \\
\hline Umidade & 5 & & \\
\hline
\end{tabular}

\begin{tabular}{|c|c|c|c|c|}
\hline \multicolumn{5}{|c|}{ ESCADAS / RAMPAS } \\
\hline $\begin{array}{l}\text { Nome do Elemento: Escadas / } \\
\text { Rampas }\end{array}$ & \multicolumn{4}{|c|}{ Data da vistoria: } \\
\hline Local: & \multicolumn{4}{|c|}{ Realizada por: } \\
\hline Danos & Fp & $\mathbf{F i}$ & D & Croquis/ Observações \\
\hline Carbonatação & 3 & & & \\
\hline Cobrimento deficiente & 3 & & & \\
\hline Contaminação por cloretos & 4 & & & \\
\hline Corrosão de armaduras & 5 & & & \\
\hline Desagregação & 3 & & & \\
\hline Desplacamento & 3 & & & \\
\hline Eflorescência & 2 & & & \\
\hline Falhas de concretagem & 2 & & & \\
\hline Fissuras & $\begin{array}{l}2 \mathrm{a} \\
5^{*}\end{array}$ & & & \\
\hline Manchas & 3 & & & \\
\hline Flechas & 5 & & & \\
\hline Sinais de esmagamento & 3 & & & \\
\hline Umidade & 3 & & & \\
\hline
\end{tabular}




\begin{tabular}{|l|c|c|c|c|}
\hline \multicolumn{5}{|c|}{ CORTINAS/ FUSTE ( MURO DE ARRIMO) } \\
\hline Nome do Elemento: Cortinas / Fuste & \multicolumn{2}{c|}{ Data da vistoria: } \\
\hline \multicolumn{1}{|c|}{ Danos } & \multicolumn{2}{c|}{ Realizada por: } \\
\hline Cacal: & Fp & Fi & D & \multicolumn{2}{|c|}{ Croquis/ Observações } \\
\hline Carbonatação & 3 & & & \multirow{2}{*}{} \\
\hline Cobrimento deficiente & 3 & & & \\
\hline Contaminação por cloretos & 4 & & & \\
\hline Corrosão de armaduras & 5 & & & \\
\hline Desagregação & 3 & & & \\
\hline Desplacamento & 3 & & & \\
\hline Eflorescência & 2 & & & \\
\hline Falhas de concretagem & 2 & & & \\
\hline & 2 a & & & \\
\hline Fissuras & $5 *$ & & & \\
\hline Manchas & 3 & & \\
\hline Desvio de geometria & 3 & & \\
\hline Sinais de esmagamento & 5 & & & \\
\hline Umidade & 3 & & & \\
\hline Desplacamento por empuxo & 5 & & & \\
\hline Desplacamento & 3 & & & \\
\hline
\end{tabular}

\begin{tabular}{|l|c|c|c|c|}
\hline \multicolumn{4}{|c|}{ RESERVATÓRIOS - SUPERIOR E INFERIOR } \\
\hline Nome do Elemento: Reservatórios & \multicolumn{3}{|c|}{ Data da vistoria: } \\
\hline \multicolumn{1}{|c|}{ Danos } & Realizada por: \\
\hline Carbonatação & Fp & Fi & D & \multicolumn{2}{|c|}{ Croquis/ Observações } \\
\hline Cobrimento deficiente & 3 & & & \\
\hline Contaminação por cloretos & 4 & & & \\
\hline Corrosão de armaduras & 5 & & & \\
\hline Desagregação & 3 & & & \\
\hline Desplacamento & 3 & & & \\
\hline Eflorescência & 2 & & & \\
\hline Falhas de concretagem & 3 & & & \\
\hline Fissuras & 2 a $5^{*}$ & & & \\
\hline Impermeabilização deficiente & 4 & & & \\
\hline Vazamento & 4 & & & \\
\hline
\end{tabular}




\begin{tabular}{|l|c|c|c|c|}
\hline \multicolumn{4}{|c|}{ BLOCO DE FUNDAÇÃO } \\
\hline Nome do Elemento: Bloco de Fundação & \multicolumn{2}{|c|}{ Data da vistoria: } \\
\hline \multicolumn{1}{|c|}{ Lanos } & \multicolumn{2}{|c|}{ Realizada por: } \\
\hline Carbonatação & Fp & Fi & D & \multicolumn{2}{|c|}{ Croquis/ Observações } \\
\hline Cobrimento deficiente & 3 & & & \multirow{2}{*}{} \\
\hline Contaminação por cloretos & 3 & & & \\
\hline Corrosão de armaduras & 4 & & & \\
\hline Desagregação & 5 & & & \\
\hline Desplacamento & 3 & & & \\
\hline Eflorescência & 3 & & & \\
\hline Falhas de concretagem & 2 & & & \\
\hline & 3 & & & \\
\hline Fissuras & 2 a & & & \\
\hline Recalque & $5 *$ & & \\
\hline Sinais de esmagamento & 5 & & & \\
\hline Umidade na base & 5 & & & \\
\hline
\end{tabular}

\begin{tabular}{|l|c|c|c|c|}
\hline \multicolumn{3}{|c|}{ ELEMENTOS DE COMPOSIÇÃO ARQUITETÔNICA } \\
\hline Nome do Elemento: & \multicolumn{2}{|c|}{ Data da vistoria: } \\
\hline Local: & \multicolumn{2}{|c|}{ Realizada por: } \\
\hline \multicolumn{1}{|c|}{ Danos } & Fp & Fi & D & \multicolumn{2}{|c|}{ Croquis/ Observações } \\
\hline Carbonatação & 3 & & & \multirow{2}{*}{} \\
\hline Cobrimento deficiente & 3 & & & \\
\hline Contaminação por cloretos & 4 & & & \\
\hline Corrosão de armaduras & 5 & & & \\
\hline Desagregação & 3 & & & \\
\hline Desplacamento & 3 & & & \\
\hline Eflorescência & 2 & & & \\
\hline Falhas de concretagem & 2 & & & \\
\hline Fissuras & 2 a 5* & & & \\
\hline Manchas & 3 & & & \\
\hline Sinais de esmagamento & 5 & & & \\
\hline Umidade & 3 & & & \\
\hline
\end{tabular}


Tabela B.3: Tipologias de fissuras em elemento de concreto armado - Fonseca (2007)

\begin{tabular}{|c|c|c|c|c|}
\hline & Fissuras* & Descrição & Croquis & Fp \\
\hline \multirow{3}{*}{ 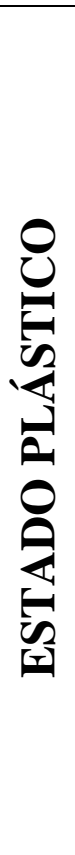 } & $\begin{array}{l}\text { de retração } \\
\text { plástica do } \\
\text { concreto }\end{array}$ & $\begin{array}{l}\text { - comuns em lajes e paredes; } \\
\text { - paralelas, superficiais e } \\
\text { afastadas de } 0,3 \text { a } 1,0 \mathrm{~m} \text {. }\end{array}$ & & 2 \\
\hline & $\begin{array}{c}\text { de } \\
\text { assentamento } \\
\text { do concreto }\end{array}$ & $\begin{array}{l}\text { - acompanham as armaduras; } \\
\text { - em pilares, ficam abaixo dos } \\
\text { estribos; } \\
\text { - interagem com armaduras } \\
\text { vizinhas. }\end{array}$ & & 3 \\
\hline & $\begin{array}{l}\text { de } \\
\text { movimentaçã } \\
\text { o de fôrmas }\end{array}$ & $\begin{array}{l}\text { - indicam mau posicionamento, } \\
\text { má fixação ou resistência } \\
\text { insuficiente de fôrmas e } \\
\text { escoramentos. }\end{array}$ & v & 3 \\
\hline \multirow{2}{*}{ 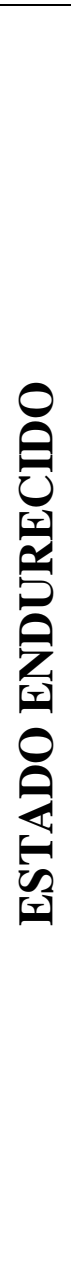 } & $\begin{array}{l}\text { De retração } \\
\text { do concreto } \\
\text { por secagem }\end{array}$ & $\begin{array}{l}\text { - vigas podem ocasionar } \\
\text { fissuras nos pilares e vice- } \\
\text { versa, por diferenças de rigidez } \\
\text { (a); } \\
\text { - aspecto de mosaico em lajes e } \\
\text { paredes, podendo aparecer em } \\
\text { ambas as faces (b); } \\
\text { - indicam restrição de } \\
\text { movimentos; } \\
\text { - profundidade reduzida; } \\
\text { - aberturas de } 0,1 \text { a } 0,2 \mathrm{~mm} \text {. }\end{array}$ & (a) & 3 \\
\hline & mapeadas & $\begin{array}{l}\text { - mais visíveis em superfícies } \\
\text { lisas de lajes e paredes; } \\
\text { - abertura e extensão reduzidas; } \\
\text { - indicam desempenho } \\
\text { excessivo; } \\
\text { - danos apenas estéticos, em } \\
\text { geral }\end{array}$ & 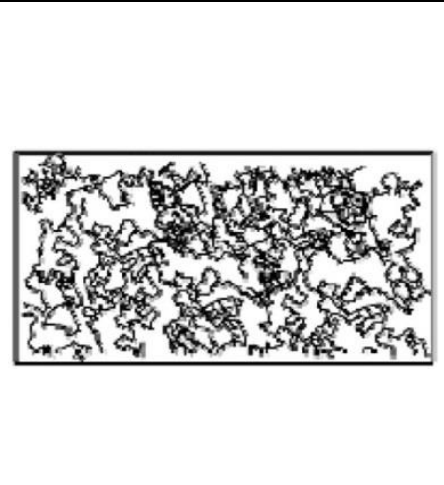 & 2 \\
\hline
\end{tabular}




\begin{tabular}{|c|c|c|c|c|}
\hline & $\begin{array}{l}\text { de variações } \\
\text { de } \\
\text { temperatura }\end{array}$ & $\begin{array}{l}\text { - em geral, normais ao eixo de } \\
\text { elementos lineares; } \\
\text { - indicam restrição de } \\
\text { movimento por mau } \\
\text { funcionamento de juntas de } \\
\text { dilatação e/ou sua inexistência. }\end{array}$ & Q & 3 \\
\hline \multirow{5}{*}{ 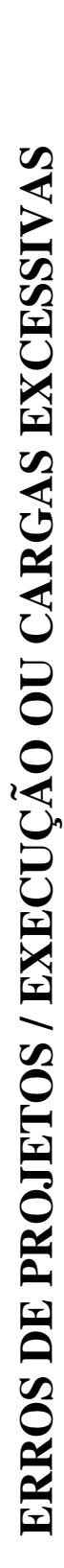 } & Fissuras* & Descrição & Croquis & Fp \\
\hline & $\begin{array}{c}\text { de flexão em } \\
\text { vigas }\end{array}$ & $\begin{array}{l}\text { - normais ao eixo, em trechos } \\
\text { de momento fletor elevado e } \\
\text { com boa aderência aço- } \\
\text { concreto. }\end{array}$ & & 4 \\
\hline & $\begin{array}{l}\text { de força } \\
\text { cortante - } \\
\text { flexão em } \\
\text { vigas }\end{array}$ & $\begin{array}{l}\text { - inclinadas nas duas faces; } \\
\text { - podem entrar na zona de } \\
\text { compressão e se dirigir aos } \\
\text { apoios. }\end{array}$ & 市积 & 4 \\
\hline & $\begin{array}{l}\text { de cortante, } \\
\text { momentos de } \\
\text { torção e } \\
\text { flexão em } \\
\text { vigas }\end{array}$ & $\begin{array}{l}\text { - inclinadas em uma face; } \\
\text { - na face oposta: menor } \\
\text { abertura e inclinação. }\end{array}$ & C淎 & 4 \\
\hline & $\begin{array}{l}\text { de flexo- } \\
\text { tração em } \\
\text { pilares }\end{array}$ & $\begin{array}{l}\text { - normais ao eixo do pilar na } \\
\text { face tracionada; } \\
\text { - paralelas ao eixo na face } \\
\text { comprimida, podem indicar } \\
\text { esmagamento do concreto; } \\
\text { - mais próximas de } \\
\text { extremidade com maior } \\
\text { momento. }\end{array}$ & & 5 \\
\hline
\end{tabular}




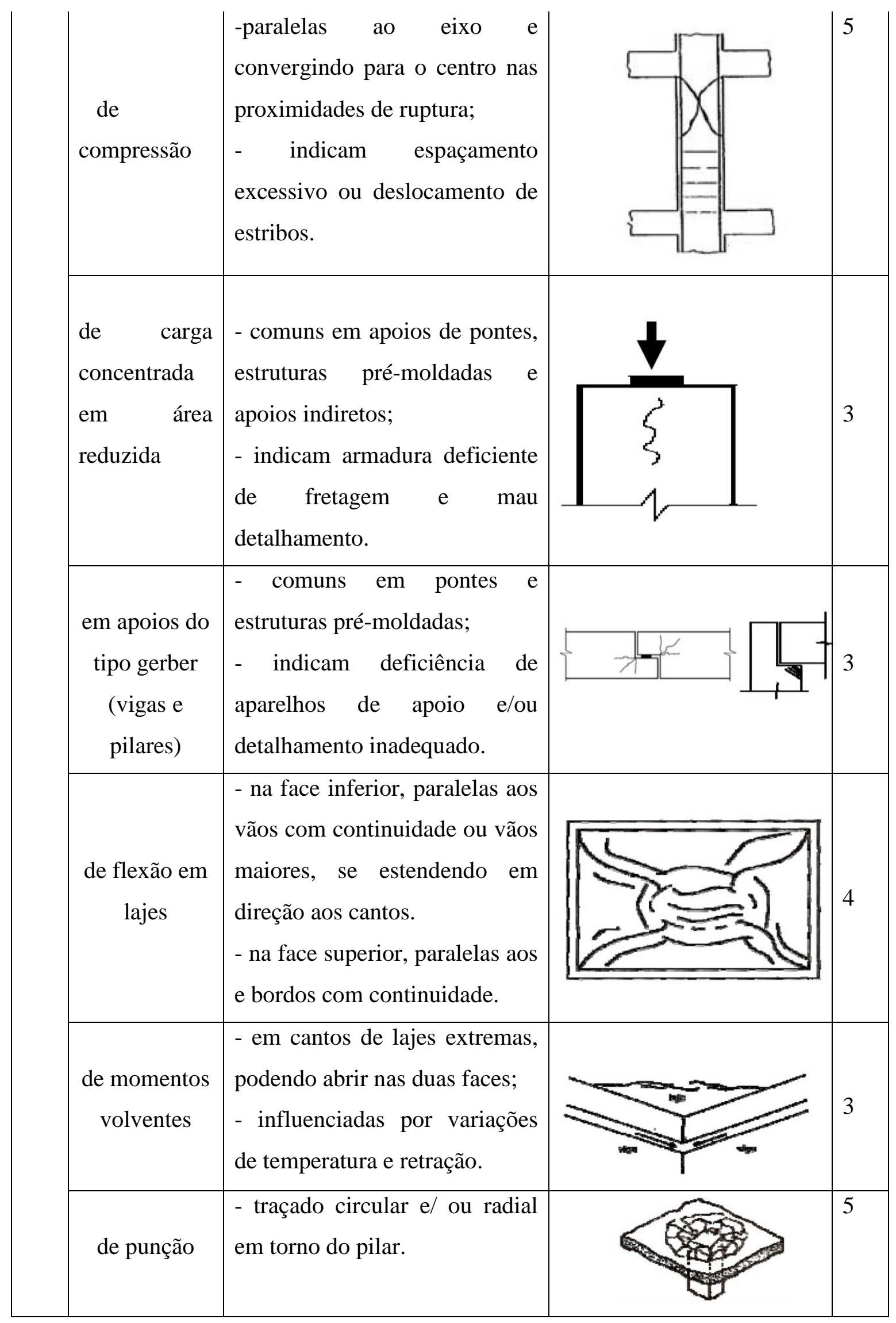


ASSOCIAÇÃO BRASILEIRA DE NORMAS TÉCNICAS, ABNT. Projetos de estrutura de concreto- Procedimento. NBR 6118. Rio de Janeiro, RJ, 2003.

ASSOCIAÇÃO BRASILEIRA DE NORMAS TÉCNICAS, ABNT. Projetos de estrutura de concreto armado - Procedimento. NBR 6118. Rio de Janeiro, RJ, 2014.

BOLDO, P. (2002). Avaliação quantitativa de estruturas de concreto armado de edificações no âmbito do Exército Brasileiro. Dissertação de Mestrado, Universidade de Brasília, DF, janeiro.

BOLDO, P., CLÍMACO, J.C.T.S. (2002). Avaliação quantitativa do grau de deterioração de estruturas de concreto de edificações públicas. Resumo aprovado para o ENTAC 2002 - Foz do Iguaçu - PR.

BOLDO, P., CLÍMACO, J.C.T.S. (2002). Avaliação quantitativa de estruturas de concreto armado de edificações no âmbito do Exército Brasileiro. Resumo aprovado para as XXX Jornadas Sul Americanas de Engenharia Estrutural - Brasília - DF.

CÁNOVAS, M.F. (1988). Patologia e terapia do concreto armado. Editora Pini, São Paulo, 522p.

CAPUTO, H. P. (1981). Mecânica dos Solos e suas aplicações. V. 2, Livros Técnicos e Científicos Editora S. A., Rio de Janeiro, 488p.

CASTRO, E. K. (1994). Desenvolvimento de metodologia para manutenção de estruturas de concreto armado. Dissertação de Mestrado, Universidade de Brasília, DF, $185 p$, dezembro.

CASTRO, E.K., CLÍMACO, J.C.T.S., NEPOMUCENO, A.A. (1995). Desenvolvimento de uma metodologia de manutenção de estruturas de concreto armado. $37^{\mathrm{a}}$ Reunião Anual do Instituto Brasileiro do Concreto - IBRACON, Anais, Vol.1, pp. 293-307, Goiânia, julho.

CASTRO, E.K., CLÍMACO, J.C.T.S. (1999). Avaliação da estrutura de uma edificação residencial após o reparo de elementos danificados. 410 Congresso Brasileiro do Concreto - IBRACON, Anais, Salvador.

LOPES, B.A.R. (1998). Sistema de manutenção predial para grandes estoques de edifícios: estudo para inclusão do componente estrutura de concreto. Dissertação de Mestrado, Universidade de Brasília, Brasília, DF, 308p, setembro. 
ISAIA, G.C., (2005). CONCRETO: Ensino, Pesquisa e Realizações. IBRACON, São Paulo SP, 1600p.

LOPES, B.A.R., CLÍMACO, J.C.T.S., NEPOMUCENO, A.A., CASTRO, E.K. (1999). Sistema de manutenção para grandes estoques de edifícios. CONPAT 99, Anais, Vol. 3, pp 1897-1905, Montevideo - Uruguai, outubro.

MEHTA, P.K.; MONTEIRO, P. J. M. (1994). Concreto, Estrutura, Propriedades e Materiai. Editora PINI, São Paulo, 580p.

MOSKVIN, V.; IVANOV, F.; ALEKSEYEV, S.; GUZEYEV, E. (1983). Concrete and Reinforced Concrete Deterioration and Protection. Mir Publishers, Moscow, Russia, 400p.

NEPOMUCENO, A.A. (1999). Patologia, recuperação e manutenção de estruturas. Notas de Aula, Departamento de Engenharia Civil e Ambiental da Universidade de Brasília, agosto.

SOUZA, V.C.M. e RIPPER, T. (1999). Patologia, recuperação e reforço de estruturas de concreto. Editora PINI, São Paulo, 250p.

VARGAS, M. (1981). Introdução à Mecânica dos Solos. Editora McGraw-Hill, São Paulo, 509p. 